\title{
Cochrane
}

Library

Cochrane Database of Systematic Reviews

\section{Swallowing therapy for dysphagia in acute and subacute stroke} (Review)

Bath PM, Lee HS, Everton LF

Bath PM, Lee HS, Everton LF.

Swallowing therapy for dysphagia in acute and subacute stroke.

Cochrane Database of Systematic Reviews 2018, Issue 10. Art. No.: CD000323.

DOI: 10.1002/14651858.CD000323.pub3.

www.cochranelibrary.com 
TABLE OF CONTENTS

HEADER

ABSTRACT

PLAIN LANGUAGE SUMMARY

SUMMARY OF FINDINGS

BACKGROUND

OBJECTIVES

METHODS

RESULTS

Figure 1.

Figure 2.

DISCUSSION

AUTHORS' CONCLUSIONS

ACKNOWLEDGEMENTS

REFERENCES

CHARACTERISTICS OF STUDIES

DATA AND ANALYSES

Analysis 1.1. Comparison 1 Swallowing therapy, Outcome 1 Functional outcome - death or dependency, death or disability at end of trial.

Analysis 1.2. Comparison 1 Swallowing therapy, Outcome 2 Case fatality at end of trial.

Analysis 1.3. Comparison 1 Swallowing therapy, Outcome 3 Length of inpatient stay (days).

Analysis 1.4. Comparison 1 Swallowing therapy, Outcome 4 Proportion of participants with dysphagia at end of trial.

Analysis 1.5. Comparison 1 Swallowing therapy, Outcome 5 Swallowing ability.

Analysis 1.6. Comparison 1 Swallowing therapy, Outcome 6 Penetration aspiration score.

Analysis 1.7. Comparison 1 Swallowing therapy, Outcome 7 Chest infection or pneumonia.

Analysis 1.8. Comparison 1 Swallowing therapy, Outcome 8 Pharyngeal transit time (seconds).

Analysis 1.9. Comparison 1 Swallowing therapy, Outcome 9 Institutionalisation.

Analysis 1.10. Comparison 1 Swallowing therapy, Outcome 10 Nutritional (albumin). APPENDICES

WHAT'S NEW

HISTORY

CONTRIBUTIONS OF AUTHORS

DECLARATIONS OF INTEREST

SOURCES OF SUPPORT

DIFFERENCES BETWEEN PROTOCOL AND REVIEW

INDEX TERMS 
[Intervention Review]

\section{Swallowing therapy for dysphagia in acute and subacute stroke}

Philip M Bath ${ }^{1}$, Han Sean Lee1, Lisa F Everton ${ }^{1}$

1Stroke Trials Unit, Division of Clinical Neuroscience, University of Nottingham, City Hospital, Nottingham, UK

Contact address: Philip M Bath, Stroke Trials Unit, Division of Clinical Neuroscience, University of Nottingham, City Hospital, Nottingham, NG5 1PB, UK. philip.bath@nottingham.ac.uk.

Editorial group: Cochrane Stroke Group.

Publication status and date: New search for studies and content updated (no change to conclusions), published in Issue 10, 2018.

Citation: Bath PM, Lee HS, Everton LF. Swallowing therapy for dysphagia in acute and subacute stroke. Cochrane Database of Systematic Reviews 2018, Issue 10. Art. No.: CD000323. DOI: 10.1002/14651858.CD000323.pub3.

Copyright $\odot 2018$ The Cochrane Collaboration. Published by John Wiley \& Sons, Ltd.

\section{A B S T R A C T}

\section{Background}

Dysphagia (swallowing problems), which is common after stroke, is associated with increased risk of death or dependency, occurrence of pneumonia, poor quality of life, and longer hospital stay. Treatments provided to improve dysphagia are aimed at accelerating recovery of swallowing function and reducing these risks. This is an update of the review first published in 1999 and updated in 2012.

\section{Objectives}

To assess the effects of swallowing therapy on death or dependency among stroke survivors with dysphagia within six months of stroke onset.

\section{Search methods}

We searched the Cochrane Stroke Group Trials Register (26 June 2018), the Cochrane Central Register of Controlled Trials (CENTRAL; 2018, Issue 6) in the Cochrane Library (searched 26 June 2018), MEDLINE (26 June 2018), Embase (26 June 2018), the Cumulative Index to Nursing and Allied Health Literature (CINAHL) (26 June 2018), Web of Science Core Collection (26 June 2018), SpeechBITE (28 June 2016), ClinicalTrials.Gov (26 June 2018), and the World Health Organization International Clinical Trials Registry Platform (26 June 2018$)$. We also searched Google Scholar (7 June 2018) and the reference lists of relevant trials and review articles.

\section{Selection criteria}

We sought to include randomised controlled trials (RCTs) of interventions for people with dysphagia and recent stroke (within six months).

\section{Data collection and analysis}

Two review authors independently applied the inclusion criteria, extracted data, assessed risk of bias, used the GRADE approach to assess the quality of evidence, and resolved disagreements through discussion with the third review author (PB). We used random-effects models to calculate odds ratios (ORs), mean differences (MDs), and standardised mean differences (SMDs), and provided 95\% confidence intervals (Cls) for each.

The primary outcome was functional outcome, defined as death or dependency (or death or disability), at the end of the trial. Secondary outcomes were case fatality at the end of the trial, length of inpatient stay, proportion of participants with dysphagia at the end of the trial, swallowing ability, penetration aspiration score, or pneumonia, pharyngeal transit time, institutionalisation, and nutrition.

\section{Main results}

We added 27 new studies (1777 participants) to this update to include a total of 41 trials (2660 participants). 
We assessed the efficacy of swallowing therapy overall and in subgroups by type of intervention: acupuncture (11 studies), behavioural interventions (nine studies), drug therapy (three studies), neuromuscular electrical stimulation (NMES; six studies), pharyngeal electrical stimulation (PES; four studies), physical stimulation (three studies), transcranial direct current stimulation (tDCS; two studies), and transcranial magnetic stimulation (TMS; nine studies).

Swallowing therapy had no effect on the primary outcome (death or dependency/disability at the end of the trial) based on data from one trial (two data sets) (OR 1.05, 95\% Cl 0.63 to $1.75 ; 306$ participants; 2 studies; $I^{2}=0 \% ; P=0.86$; moderate-quality evidence). Swallowing therapy had no effect on case fatality at the end of the trial (OR 1.00, $95 \% \mathrm{Cl} 0.66$ to $1.52 ; 766$ participants; 14 studies; $I^{2}=6 \% ; \mathrm{P}=0.99$; moderate-quality evidence). Swallowing therapy probably reduced length of inpatient stay (MD $-2.9,95 \% \mathrm{Cl}-5.65$ to $-0.15 ; 577$ participants; 8 studies; $I^{2}=11 \% ; P=0.04 ;$ moderate-quality evidence). Researchers found no evidence of a subgroup effect based on testing for subgroup differences $(\mathrm{P}=0.54)$. Swallowing therapy may have reduced the proportion of participants with dysphagia at the end of the trial $(\mathrm{OR} 0.42$, $95 \% \mathrm{Cl} 0.32$ to $0.55 ; 1487$ participants; 23 studies; $I^{2}=0 \% ; P=0.00001 ;$ low-quality evidence). Trial results show no evidence of a subgroup effect based on testing for subgroup differences $(P=0.91)$. Swallowing therapy may improve swallowing ability $(S M D-0.66,95 \% \mathrm{Cl}-1.01$ to $-0.32 ; 1173$ participants; 26 studies; $I^{2}=86 \% ; P=0.0002$; very low-quality evidence). We found no evidence of a subgroup effect based on testing for subgroup differences $(P=0.09)$. We noted moderate to substantial heterogeneity between trials for these interventions. Swallowing therapy did not reduce the penetration aspiration score (i.e. it did not reduce radiological aspiration) (SMD $-0.37,95 \% \mathrm{Cl}-0.74$ to $-0.00 ; 303$ participants; 11 studies; $I^{2}=46 \% ; P=0.05$; low-quality evidence). Swallowing therapy may reduce the incidence of chest infection or pneumonia (OR $0.36,95 \% \mathrm{Cl} 0.16$ to $0.78 ; 618$ participants; 9 studies; $I^{2}=59 \% ; P=0.009$; very low-quality evidence).

\section{Authors' conclusions}

Moderate- and low-quality evidence suggests that swallowing therapy did not have a significant effect on the outcomes of death or dependency/disability, case fatality at the end of the trial, or penetration aspiration score. However, swallowing therapy may have reduced length of hospital stay, dysphagia, and chest infections, and may have improved swallowing ability. However, these results are based on evidence of variable quality, involving a variety of interventions. Further high-quality trials are needed to test whether specific interventions are effective.

\section{PLAIN LANGUAGE SUMMARY}

\section{Swallowing therapy for difficulties with swallowing in stroke survivors who have had a recent stroke}

\section{Question}

We wanted to assess the effectiveness of swallowing therapy for stroke survivors with dysphagia (difficulty in swallowing). We looked at swallowing therapy in survivors up to six months after stroke.

\section{Background}

Stroke often results in difficulty swallowing. This can lead to choking, chest infections, poorer quality of life, longer hospital stay, and increased risk of death or discharge to a care home. Therapy to improve swallowing aims to speed up recovery of swallowing function and reduce these risks.

\section{Study characteristics}

This is an update of the review originally published in 1999 and previously updated in 2012 . We have now included a total of 41 studies (2660 participants), and the evidence is current to June 2018. Swallowing therapy comprises several different treatment types, and we looked at eight of these: acupuncture (11 studies), behavioural interventions (nine studies), drug therapy (three studies), neuromuscular electrical stimulation (NMES; six studies), pharyngeal electrical stimulation (PES; four studies), physical stimulation (three studies), transcranial direct current stimulation (tDCS; two studies), and transcranial magnetic stimulation (TMS; nine studies).

\section{Key results}

Swallowing therapy did not result in less death or disability among stroke survivors, nor did it lead to a safer swallow after treatment. However, some individual swallowing therapies seemed to reduce hospital length of stay, lessen the chance of getting a chest infection or pneumonia, or improve swallowing ability and recovery from swallowing problems. Many of the swallowing therapies involved different methods of delivery, so it is still not clear which approach is most effective for each type of therapy.

\section{Quality of the evidence}

The quality of the evidence was generally very low, low, or moderate. Additional high-quality studies are needed. 
SUMMARY OF FINDINGS

Summary of findings for the main comparison. Swallowing therapy compared to placebo for dysphagia in acute and subacute stroke

Swallowing therapy compared to placebo for dysphagia in acute and subacute stroke

Patient or population: dysphagia in acute and subacute stroke

Setting: in hospital

Intervention: swallowing therapy

Comparison: placebo

\begin{tabular}{|c|c|c|c|c|c|c|}
\hline \multirow[t]{2}{*}{ Outcomes } & \multicolumn{2}{|c|}{ Anticipated absolute effects` $(95 \% \mathrm{Cl})$} & \multirow{2}{*}{$\begin{array}{l}\text { Relative effect } \\
(95 \% \mathrm{Cl})\end{array}$} & \multirow{2}{*}{$\begin{array}{l}\text { No. of partici- } \\
\text { pants } \\
\text { (studies) }\end{array}$} & \multirow{2}{*}{$\begin{array}{l}\text { Certainty of } \\
\text { the evidence } \\
\text { (GRADE) }\end{array}$} & \multirow[t]{2}{*}{ Comments } \\
\hline & Risk with placebo & Risk with swallowing therapy & & & & \\
\hline $\begin{array}{l}\text { Death or dependency at } \\
\text { end of trial }\end{array}$ & 693 per 1000 & $\begin{array}{l}703 \text { per } 1000 \\
\text { (587 to } 798)\end{array}$ & $\begin{array}{l}\text { OR } 1.05 \\
\text { (0.63 to } 1.75)\end{array}$ & $\begin{array}{l}306 \\
(2 \mathrm{RCTs})\end{array}$ & $\begin{array}{l}\oplus \oplus \oplus \ominus \\
\text { Moderate }\end{array}$ & a \\
\hline Case fatality at end of trial & 197 per 1000 & $\begin{array}{l}197 \text { per } 1000 \\
\text { (140 to } 272)\end{array}$ & $\begin{array}{l}\text { OR } 1.00 \\
\text { (0.66 to } 1.52 \text { ) }\end{array}$ & $\begin{array}{l}766 \\
(14 \mathrm{RCTs})\end{array}$ & $\begin{array}{l}\oplus \oplus \oplus \ominus \\
\text { Moderate }\end{array}$ & $b$ \\
\hline $\begin{array}{l}\text { Length of inpatient stay } \\
\text { (days) }\end{array}$ & $\begin{array}{l}\text { Mean length of inpatient } \\
\text { stay (days) ranged from } 19 \\
\text { to } 119\end{array}$ & $\begin{array}{l}\text { MD } 2.9 \text { lower } \\
\text { (5.65 lower to } 0.15 \text { lower) }\end{array}$ & - & $\begin{array}{l}577 \\
(8 \mathrm{RCTs})\end{array}$ & $\begin{array}{l}\oplus \oplus \oplus \ominus \\
\text { Moderate }\end{array}$ & c \\
\hline \multirow{2}{*}{$\begin{array}{l}\text { Proportion of participants } \\
\text { with dysphagia at end of } \\
\text { trial }\end{array}$} & \multicolumn{2}{|l|}{ Study population } & \multirow{2}{*}{$\begin{array}{l}\text { OR } 0.42 \\
(0.32 \text { to } 0.55)\end{array}$} & \multirow{2}{*}{$\begin{array}{l}1487 \\
(23 \text { RCTs) }\end{array}$} & \multirow{2}{*}{$\begin{array}{l}\oplus \oplus \ominus \ominus \\
\text { Low }\end{array}$} & \multirow[t]{2}{*}{$d$} \\
\hline & 570 per 1000 & $\begin{array}{l}357 \text { per } 1000 \\
(298 \text { to } 421)\end{array}$ & & & & \\
\hline Swallowing ability & $\begin{array}{l}\text { Mean swallowing ability } \\
\text { was } 0\end{array}$ & $\begin{array}{l}\text { SMD } 0.66 \text { lower } \\
\text { (1.01 lower to } 0.32 \text { lower) }\end{array}$ & - & $\begin{array}{l}1173 \\
\text { (26 RCTs) }\end{array}$ & $\begin{array}{l}\oplus \ominus \ominus \ominus \\
\text { Very low }\end{array}$ & e \\
\hline $\begin{array}{l}\text { Penetration aspiration } \\
\text { score }\end{array}$ & $\begin{array}{l}\text { Mean penetration aspira- } \\
\text { tion score was } 0\end{array}$ & $\begin{array}{l}\text { SMD } 0.37 \text { lower } \\
(0.74 \text { lower to } 0)\end{array}$ & - & $\begin{array}{l}303 \\
\text { (11 RCTs) }\end{array}$ & $\begin{array}{l}\oplus \oplus \ominus \ominus \\
\text { Low }\end{array}$ & $f$ \\
\hline \multirow{2}{*}{$\begin{array}{l}\text { Adverse event: chest in- } \\
\text { fection or pneumonia }\end{array}$} & Study population & & \multirow{2}{*}{$\begin{array}{l}\text { OR } 0.34 \\
\text { (0.17 to } 0.71)\end{array}$} & \multirow{2}{*}{$\begin{array}{l}676 \\
(10 \text { RCTs })\end{array}$} & \multirow{2}{*}{$\begin{array}{l}\oplus \ominus \ominus \ominus \\
\text { Very low }\end{array}$} & \multirow[t]{2}{*}{$\mathrm{g}$} \\
\hline & 343 per 1000 & 151 per 100 & & & & \\
\hline
\end{tabular}


*The risk in the intervention group (and its $95 \%$ confidence interval) is based on the assumed risk in the comparison group and the relative effect of the intervention (and its $95 \% \mathrm{Cl})$.

Cl: confidence interval; OR: odds ratio; RCT: randomised controlled trial.

\section{GRADE Working Group grades of evidence.}

High certainty: we are very confident that the true effect lies close to that of the estimate of the effect.

Moderate certainty: we are moderately confident in the effect estimate: the true effect is likely to be close to the estimate of the effect, but there is a possibility that it is substantially different.

Low certainty: our confidence in the effect estimate is limited: the true effect may be substantially different from the estimate of the effect.

Very low certainty: we have very little confidence in the effect estimate: the true effect is likely to be substantially different from the estimate of effect.

aDowngraded by one level due to lack of precision (one study split into two trials).

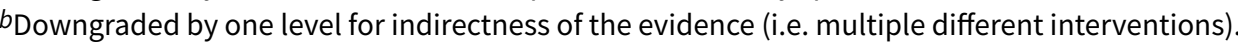

'Downgraded by one level due to indirectness of the evidence (i.e. multiple different interventions). Note also that two studies had unclear blinding.

$d$ Downgraded by two levels due to indirectness of the evidence and blinding - a large number of studies did not clarify blinding status.

eDowngraded by three levels due to indirectness of the evidence (i.e. multiple different interventions), considerable heterogeneity, and fair number of studies did not clarify blinding status.

fDowngraded by two levels due to indirectness of the evidence (i.e. multiple different interventions) and moderate heterogeneity.

gDowngraded by three levels due to indirectness of the evidence (i.e. multiple different interventions), substantial heterogeneity, and fair number of studies did not clarify blinding status. 


\section{B A C K G R O U N D}

\section{Description of the condition}

Dysphagia after stroke is common, affecting $27 \%$ to $64 \%$ of stroke survivors (Gordon 1987; Wolfe 1993; Odderson 1995; Smithard 1996; Mann 2000; Singh 2006a; Rofes 2013). Although dysphagia improves spontaneously in many people with stroke (by two weeks in about half), some will die and $15 \%$ of stroke survivors will still have swallowing problems at one month (Smithard 1993); many of these individuals require long-term feeding with significant impairment of function, recovery, and quality of life (Barer 1989; Smithard 1997; Mann 1999; Perry 2004). Complications of dysphagia include aspiration leading to chest infection and pneumonia, malnutrition, inability to rehabilitate, increased risk of infection, prolonged length of stay in hospital, and increased risk of death (Smithard 1993; Odderson 1995; Finestone 1996; Smithard 1996; Sharma 2001; Martino 2005; Arnold 2016). Early identification and management of dysphagia have been shown to reduce pneumonia rates (Odderson 1995; Ramsey 2003; Hinchey 2005; Lakshminarayan 2010). Cohen 2016 recently reviewed this topic.

\section{Description of the intervention}

Speech and language therapists (SLTS) often administer interventions for treating dysphagia. These interventions involve behavioural approaches that may be compensatory or rehabilitative in nature. Compensatory approaches include modification of fluid and food consistencies, postural techniques such as adopting a chin tuck position, and swallow strategies such as a supraglottic swallow. Rehabilitative methods include swallowing exercises that focus on muscle strength; resistance or skill training, or both, such as tongue exercises, effortful swallow, and Mendelsohn's manoeuvre (Mendelsohn 1987); and the Shaker exercise (Shaker 2002). Rehabilitative methods also include peripheral sensory stimulation, such as physical stimulation with tactile, thermal, or sour stimulation (Lazarra 1986; Logemann 1991; Logemann 1993; Rosenbek 1996; U1111-1188-0335); carbonation (Krival 2008); electrical stimulation (Power 2006); and air pulses (Theurer 2013). Researchers have also studied chemical and pharmacological agents, including capsaicin, black pepper oil, cabergoline, angiotensin-converting enzyme (ACE) inhibitors, and nifedipine (Arai 2003; Ebihira 2004; Ebihira 2005).

Practitioners in China routinely use acupuncture techniques to treat dysphagia (Wong 2012).

Several other stimulation methods to promote recovery from dysphagia post stroke have emerged in recent years, in particular peripheral and central stimulation methods. Peripheral methods include pharyngeal electrical stimulation (PES), as reported in Scutt 2015, and neuromuscular surface electrical stimulation (NMES), as described in Chen 2016. Central stimulation methods, also known as non-invasive brain stimulation, include transcranial magnetic stimulation (TMS) (Momosaki 2016; Pisegna 2016), as well as transcranial direct current stimulation (tDCS) (Momosaki 2016; Pisegna 2016).

\section{How the intervention might work}

The swallowing network is asymmetrically represented in both cerebral hemispheres, with one hemisphere showing dominance for swallowing (Hamdy 1998). Following unilateral stroke, TMS studies have demonstrated that recovery from dysphagia is associated with improved function of the non-lesioned hemisphere (Hamdy 1998). The aim of most of the interventions described in this review is to accelerate this process of plasticity in acute and sub-acute stroke patients with dysphagia. The exact process by which this is achieved is not fully understood, although it is thought that some interventions specifically aim to improve swallowing by enhancing sensory drive to the brain, causing increased activity in motor swallowing areas.

\section{Why it is important to do this review}

Dysphagia post stroke affects quality of life, carries increased risks of mortality and dependency (Smithard 1996; Arnold 2016), prolongs hospital stay (Smithard 1996; Smithard 1997; Arnold 2016), increases healthcare costs, and often leads to discharge from hospital to a care home (Smithard 1996; Arnold 2016). Despite all of this, the previous two versions of this review concluded in 1999 and 2012 that overall, current evidence for interventions was insufficient, and that no definitive treatments for dysphagia were available (Bath 1999; Geeganage 2012).

An updated version of this review is therefore needed to appraise current evidence regarding the effectiveness of interventions for dysphagia post stroke. This information will provide support for clinical practice; will inform stroke survivors, clinicians, and healthcare funders regarding which interventions are most effective; and may help guide policy and funding decisions. This review assesses the effectiveness of swallowing therapy for treatment of dysphagia in stroke survivors with acute or subacute stroke.

\section{O B J E C T IVES}

To assess the effects of swallowing therapy on death or dependency among stroke survivors with dysphagia within six months of stroke onset.

\section{METHODS}

\section{Criteria for considering studies for this review}

\section{Types of studies}

We identified randomised controlled trials (RCTs) of swallowing therapy for stroke survivors with acute or subacute stroke and dysphagia.

We excluded trials if they compared two or more active treatments (i.e. treatment was confounded), recruited participants after six months following stroke onset, involved a large proportion of participants with non-stroke causes of dysphagia, or used a crossover design by which we could not just use data from the first treatment phase.

For this third version of the review, we removed most trials examining postural studies and all trials examining modified fluids because they lacked a true control group. We also excluded trials of free water protocols, oral hygiene, cough reflex testing, and swallow screening, as we do not consider these to be interventions for dysphagia per se. We also excluded trials involving the use of antibiotics. 


\section{Types of participants}

\section{Definitions}

\section{Acute or subacute stroke}

Participants recruited with a clinical diagnosis of stroke within six months of onset.

\section{Stroke type}

Ischaemic or haemorrhagic.

\section{Dysphagia}

Diagnosed clinically (water swallow tests, modified diet or fluid assessments, swallowing test scores) by a clinician (typically a nurse or SLT), or by a videofluoroscopy swallow study (VFSS) or fibreoptic endoscopic evaluation of swallowing (FEES).

\section{Types of interventions}

- Acupuncture versus no acupuncture or routine acupuncture or sham acupuncture

- Behavioural interventions such as swallowing exercises, or positioning versus limited, usual, or no treatment

- Drug intervention versus none or placebo

- Neuromuscular electrical stimulation (NMES) versus none or sham stimulation

- Pharyngeal electrical stimulation (PES) versus none or sham stimulation

- Physical stimulation such as thermal or tactile versus limited, usual, or no treatment

- Transcranial direct current stimulation (tDCS) versus none or sham stimulation

- Transcranial magnetic stimulation (TMS) versus none or sham stimulation

We combined different interventions, collectively referred to as 'swallowing therapy', for the purpose of analysing their effects on the main outcomes. Given that the science of intervention development for dysphagia is at an early stage, it is reasonable to ask the question whether any intervention is better than no intervention, and to try to establish where the most positive effects are seen and for what topics more research is needed.

\section{Types of outcome measures}

We obtained information on the following outcome measures, as available, for each trial.

\section{Primary outcomes}

- Functional outcome assessed as death or dependency (modified Rankin Scale: $m R S>2$ ), or death or disability (Barthel Index: $\mathrm{BI}$ $<60$ ), at the end of the trial

We chose functional outcome (i.e. death or dependency/disability) as the primary outcome because dysphagia is associated with increased risk of death or dependency in acute and subacute stroke. Whilst swallowing therapy aims to reduce dysphagia, we needed to assess whether evidences shows that people receiving swallowing therapy are less likely to die or remain dependent. We listed other important outcomes relevant to swallowing function as secondary outcomes.

\section{Secondary outcomes}

- Case fatality at the end of the trial

- Length of inpatient stay

- Proportion of patients with dysphagia at the end of the trial

- Swallowing ability based on assessments of dysphagia impairment using the dysphagia severity rating scale (DSRS), the functional oral intake scale (FOIS), the dysphagia outcome and severity scale (DOSS), or water swallowing tests

- Penetration Aspiration score determined by VFSS and FEES and quantified on a scale such as the Penetration Aspiration Scale (PAS)

- Chest infection or pneumonia, determined clinically or radiologically

- Swallow timings from VFSS measurements (e.g. pharyngeal transit time (PTT)

- Nutritional measure based on blood albumin

- Institutionalisation with discharge to a residential, care, or nursing home, or to an extended care facility

- Neurological impairment within four weeks (e.g. using National Institutes of Health Stroke Scale (NIHSS) or Scandinavian Stroke Scale)

- Quality of life (e.g. using Short Form-36 (SF-36) or EuroQoL (measure of health-related quality of life))

\section{Search methods for identification of studies}

See the Cochrane Stroke Group search methods. We searched for trials in all languages and arranged translation of relevant articles published in languages other than English. We have listed publications requiring translation in the Characteristics of studies awaiting classification section.

\section{Electronic searches}

We searched the Cochrane Stroke Group Trials Register (last searched on 26 June 2018). In addition, we searched:

- Cochrane Central Register of Controlled Trials (CENTRAL; 2018, Issue 6) (Appendix 1) in the Cochrane Library (searched 26 June 2018);

- MEDLINE Ovid (1946 to 26 June 2018) (Appendix 2);

- Embase (1974 to 26 June 2018) (Appendix 3);

- Cumulative Index to Nursing and Allied Health Literature (CINAHL EBSCO) (1982 to 26 June 2018) (Appendix 4);

- Science Citation Index Expanded, Social Sciences Citation Index, Conference Proceedings Citation Index-Science (Web of Science Core Collection; 1900 to 26 June 2018) (Appendix 5); and

- SpeechBITE (searched 28 June 2018) (Appendix 6).

In an effort to identify further published, unpublished, and ongoing trials, we searched:

- US National Institutes of Health Ongoing Trials Register ClinicalTrials.gov (www.clinicaltrials.gov; searched 26 June 2018; Appendix 7);

- World Health Organization International Clinical Trials Registry Platform (apps.who.int/trialsearch; searched 26 June 2018; Appendix 8); and

- Google Scholar (searched 7 June 2018; Appendix 9). 


\section{Searching other resources}

Additionally, we searched the reference lists of relevant trials and review articles and our own reference lists.

For a previous version of this review (Geeganage 2012), we contacted researchers and the UK Royal College of Speech and Language Therapists Special Interest Group for information on adult-acquired dysphagia trials.

\section{Data collection and analysis}

\section{Selection of studies}

For this update, two review authors (HSL, LE) scanned the titles and abstracts of records identified through searches of electronic bibliographic databases and excluded obviously irrelevant articles. We independently reviewed the full text of remaining studies and selected relevant trials according to the listed inclusion criteria; we resolved disagreements through discussion with the third review author (PB).

\section{Data extraction and management}

For this update, two review authors (HSL, LE) extracted data using a predefined proforma, and entered the data into RevMan 5 (RevMan 2014); we resolved disagreements through discussion and consultation with the third review author (PB). We assessed information on randomisation, blinding, numbers of participants randomised, timing of treatment from stroke, types of dysphagia therapy, participant withdrawals and losses to follow-up, and relevant outcomes (Types of outcome measures). We aggregated outcome data from dose escalation or dose comparison trials into one active treatment group.

\section{Assessment of risk of bias in included studies}

We assessed potential for bias using the 'Risk of bias' tool as recommended in the Cochrane Handbook for Systematic Reviews of Interventions (Higgins 2011). This assessment includes sequence generation, allocation concealment, blinding of participants and personnel, blinding of outcome assessment, incomplete outcome data, selective outcome reporting, and other issues.

\section{Measures of treatment effect}

We assessed weighted estimate of the typical treatment effect across trials using odds ratios (ORs) and 95\% confidence intervals (Cls) for binary data, mean differences (MDs) and 95\% Cls for continuous data, and standardised mean differences (SMDs) and $95 \% \mathrm{Cls}$ for continuous data based on different scales. We performed analyses using RevMan 5 (RevMan 2014). We calculated OR using the Mantel-Haenszel method, and MDs using the inverse variance method.

\section{Unit of analysis issues}

When outcome measures included different scores, we converted these to grades in the same direction of mild to severe and analysed them using MDs. When studies compared graduations of therapy (high-medium-low intensity), we divided the middleintensity group in two and analysed study data by comparing high intensity versus medium intensity, and medium intensity versus low intensity or no treatment. Similarly, if a trial compared highversus low-frequency stimulation or unilateral versus bilateral stimulation, we divided control group participants equally between treatment groups to prevent control participants from being counted more than once, and thereby artificially narrowing the $\mathrm{Cls}$. We entered each set of data as a separate trial.

\section{Dealing with missing data}

If a trial publication did not provide relevant data or if data were missing but we felt it appropriate otherwise, we placed studies into Characteristics of studies awaiting classification.

\section{Assessment of heterogeneity}

We used the random-effects model to assess heterogeneity by looking at forest plots to see how Cls overlapped (non-overlapping studies are exhibiting statistical heterogeneity) along with the $I^{2}$ statistic (Higgins 2011). We defined thresholds for interpreting heterogeneity according to the Cochrane Handbook for Systematic Reviews of Interventions, whereby $0 \%$ to $40 \%$ might not be important; $30 \%$ to $60 \%$ may represent moderate heterogeneity; $50 \%$ to $90 \%$ may represent substantial heterogeneity, and $75 \%$ to $100 \%$ represents considerable heterogeneity (Higgins 2011).

\section{Assessment of reporting biases}

We assessed selective outcome reporting as reported in the 'Risk of bias' table (Characteristics of included studies).

\section{Data synthesis}

We performed meta-analysis using functionality within RevMan 5 (RevMan 2014): we used random-effects models (Mantel-Haenszel method) and presented data as number (\%) or mean (standard deviation), with OR, MD, or SMD. We used random-effects models because we expected that trials would be heterogeneous in design and delivery, including different types of participants and interventions.

\section{Grade and 'Summary of findings' table}

We assessed the quality of the evidence using the five GRADE considerations (study limitations, consistency of effect, imprecision, indirectness, and publication bias), as described in the Cochrane Handbook for Systematic Reviews of Interventions (Higgins 2011), for the following main outcomes of analysis.

- Death or dependency/disability at the end of the trial.

- Case fatality at the end of the trial.

- Length of inpatient stay.

- Proportion of participants with dysphagia at the end of the trial.

- Swallowing ability.

- Penetration aspiration score.

- Adverse event: chest infection or pneumonia.

We have presented in Summary of findings for the main comparison key findings of the review, including a summary of the quantity of data, the magnitude of effect size, and the overall quality of evidence.

\section{Subgroup analysis and investigation of heterogeneity}

We performed subgroup analyses on the eight different types of swallowing therapy to provide more specific information pertaining to the different interventions. We assessed for significant subgroup interactions by testing for subgroup differences for each main outcome. 


\section{Sensitivity analysis}

We did not perform sensitivity analyses due to the small number of studies.

\section{RESULTS}

\section{Description of studies}

We identified 27 new RCTs involving a total of 1777 acute or subacute stroke survivors with dysphagia.

\section{Results of the search}

We have presented the PRISMA study flow diagram in Figure 1. In total, we identified 2902 references, removed 860 duplicates, and screened 2042 records. We excluded 1874 records, leaving a total of
168 records. After full-text review, we excluded 41 studies. We added these newly excluded studies to the existing list of 39 excluded studies, for a total of 80 (Excluded studies). We added 22 studies into the ongoing studies section (Ongoing studies). We also added 78 new studies to the eight existing studies awaiting classification, yielding a total of 86 (Studies awaiting classification); these studies have been completed and are awaiting publication or are awaiting translation, or we are seeking full-text articles. External assessment of this review led to a request to further update the searches; an updated search revealed further potentially relevant studies, and we have added these to the Studies awaiting classification section; we will assess these when we prepare the next update of this review. Finally, we added 27 new studies to the existing 14 studies, yielding a total of 41 included studies ( 47 data sets) (Included studies). This resulted in the addition of 1777 participants to the existing 883 , for a total of 2660 participants. 
Figure 1. Study Flow Diagram, ${ }^{\star} 86$ studies awaiting classification.

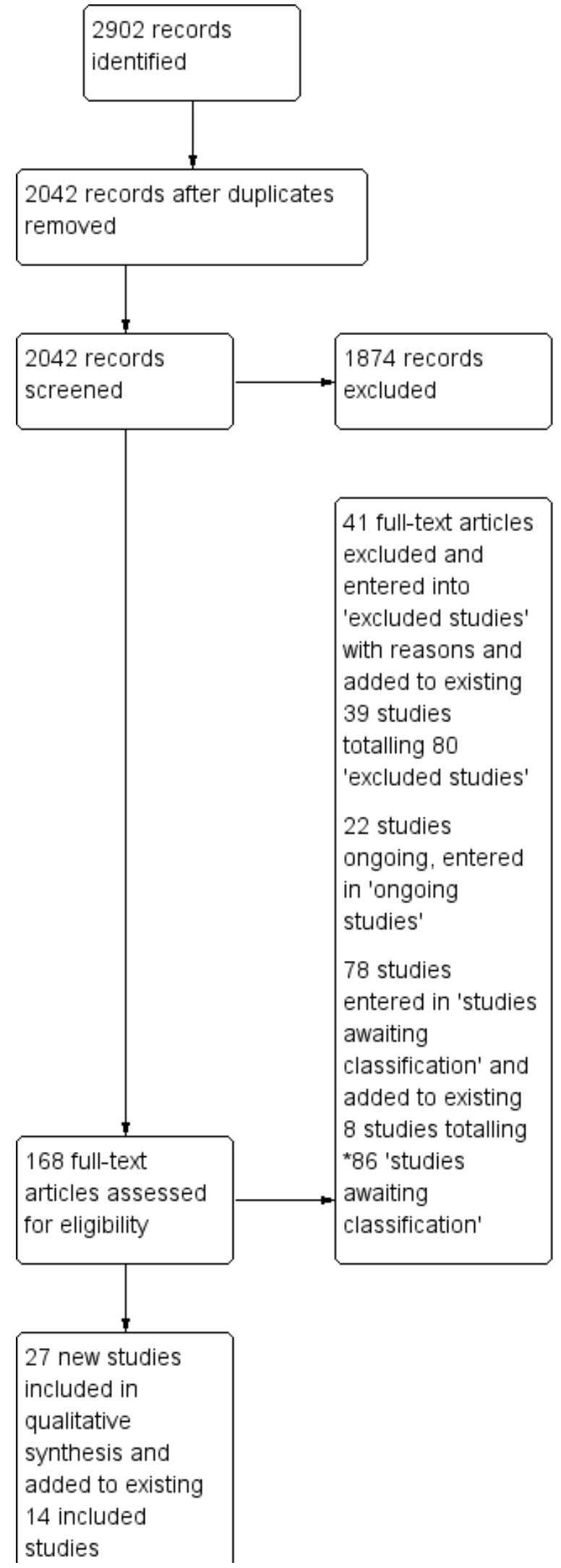


Figure 1. (Continued)

$\begin{aligned} & 14 \text { Imcluueu } \\ & \text { studies }\end{aligned}$
41 studies (split
into 47 trials)
included in
quantitative
synthesis
(meta-analysis) of
this updated
review

\section{Included studies}

We included 41 trials in this updated review (mean participant age 67.8 years). These trials looked at various forms of swallowing therapy after stroke.

When outcome measures included different scores, we converted these to grades in the same direction of mild to severe and analysed them using mean differences (MDs). Two studies compared graduations of therapy (high-medium-low intensity) (Yuan 2003i; Yuan 2003ii; Carnaby 2006i; Carnaby 2006ii;); here, we divided the middle-intensity group in two and analysed the study data by comparing high intensity versus medium intensity, and medium intensity versus low intensity or no treatment. Similarly, one trial of TMS compared high-versus low-frequency stimulation or unilateral versus bilateral stimulation (Kim 2012i; Kim 2012ii; Du 2016i; Du 2016ii; Park 2016 (a) i; Park 2016 (a) ii); here, we divided control group participants equally between treatment groups to prevent control participants from being counted more than once and thereby artificially narrowing the confidence intervals (Cls). We entered each set of data as a separate trial; hence, although the total number of included studies was 41 , the total number of data sets entered for analysis was 47.

\section{Acupuncture}

Eleven studies tested acupuncture in 998 participants (Liu 2000; Han 2004; Liu 2004; Wei 2005; Jia 2006a; Bai 2007i; Bai 2007ii; Huang 2010; Chan 2012; Chen 2016a; Xia 2016a).

\section{Behavioural interventions}

Nine studies investigated behavioural interventions in 632 participants (Yuan 2003i; Yuan 2003ii; Song 2004; Carnaby 2006i; Carnaby 2006ii; Kang 2012; Zheng 2014; Heo 2015; Park 2016b). Behavioural interventions consisted of swallowing exercises, environmental modifications such as upright positioning for feeding, safe swallowing advice, dietary modifications, kinesiotaping, and expiratory muscle strength training.

\section{Drug therapy}

Three studies assessed several different drugs in 148 participants (Perez 1997; Lee 2015; Warusevitane 2015). Drug interventions included nifedipine in 17 participants (Perez 1997), lisinopril in 71 participants (Lee 2015), and metoclopramide in 60 participants (Warusevitane 2015).

\section{Neuromuscular electrical stimulation (NMES)}

Six studies tested NMES in 312 participants (Lim 2009; Xia 2011; Park 2012; Lee 2014; Li 2014; Terre 2015). Researchers most often compared NMES versus traditional dysphagia therapy. One study combined NMES and effortful swallow (Park 2012).

\section{Pharyngeal electrical stimulation (PES)}

Four studies involving 214 participants assessed PES (Jayasekeran 2010a; Jayasekeran 2010b; STEPS 2016; Vasant 2016).

\section{Physical stimulation (thermal, tactile)}

Three studies enrolled 155 participants. Types of stimulation included tactile stimulation (Bath 1997), electrical stimulation (Power 2006), and Tongyan spray (Feng 2012).

\section{Transcranial direct current stimulation (tDCS)}

Two studies assessed tDCS in 34 participants (Kumar 2011; Shigematsu 2013).

\section{Transcranial magnetic stimulation (TMS)}

Nine studies involving 167 participants investigated TMS (Khedr 2009; Khedr 2010; Kim 2012i; Kim 2012ii; Park 2013; Du 2016i; Du 2016ii; Park 2016a (i); Park 2016a (ii).

\section{Excluded studies}

We excluded 80 studies from this updated review, most commonly because investigators compared two active treatments (confounded) or because the trials were not RCTs. We excluded 10 studies as reported outcomes were not relevant to this review. We excluded 11 studies because of lack of outcome data; some of these might be relevant to this review should outcome data become available (Characteristics of excluded studies).

\section{Risk of bias in included studies}

Key sources of bias follow; we have summarised risk of bias in Figure 2. 
Figure 2. 'Risk of bias' graph: review authors' judgements about each 'Risk of bias' item presented as percentages across all included studies.

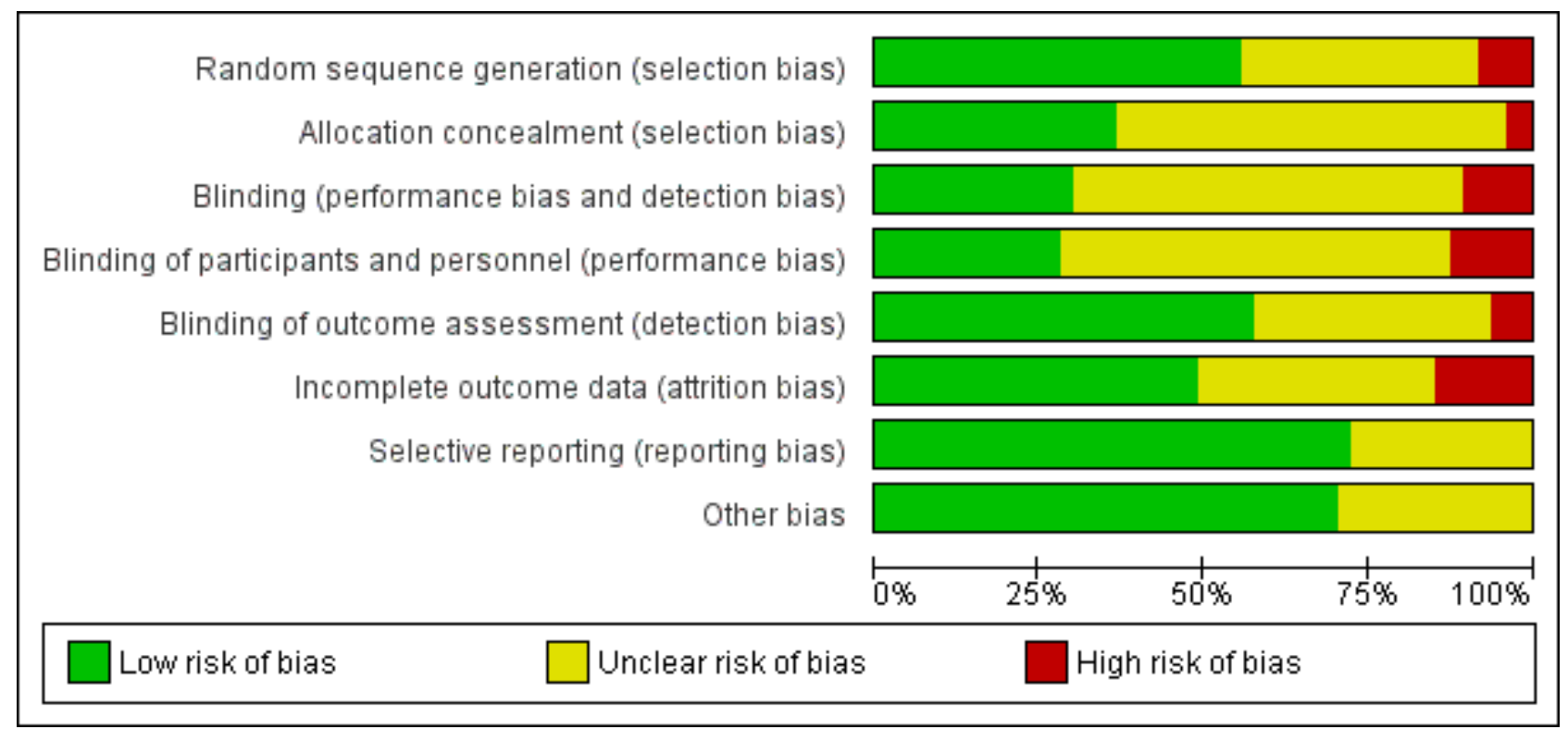

\section{Allocation}

\section{Random sequence generation}

- Randomisation by computer occurred in 15 studies (low risk of bias) (Bath 1997; Perez 1997; Carnaby 2006i; Carnaby 2006ii; Jayasekeran 2010a; Jayasekeran 2010b; Park 2012; Park 2013; Lee 2014; Li 2014; Lee 2015; Terre 2015; Chen 2016a; STEPS 2016; Vasant 2016).

- Randomisation via random number tables occurred in 10 studies (low risk of bias) (Song 2004; Bai 2007i; Bai 2007ii; Chan 2012; Feng 2012; Shigematsu 2013; Warusevitane 2015; Du 2016i; Du 2016ii; Xia 2016a).

- Simple randomisation occurred in four studies (low risk of bias) (Han 2004; Kumar 2011; Heo 2015; Park 2016b).

- Method of randomisation was unclear in 16 studies (unclear risk of bias) (Liu 2000; Yuan 2003i; Yuan 2003ii; Liu 2004; Wei 2005; Power 2006; Khedr 2009; Huang 2010; Khedr 2010; Xia 2011; Kang 2012; Kim 2012i; Kim 2012ii; Zheng 2014; Park 2016a (i); Park 2016a (ii)).

- Two studies used non-randomised methods (high risk of bias) (Jia 2006a; Lim 2009).

\section{Allocation concealment}

- Researchers ensured allocation concealment in 17 studies (low risk of bias) (Han 2004; Carnaby 2006i; Carnaby 2006ii; Khedr 2009; Chan 2012; Feng 2012; Park 2012; Park 2013; Shigematsu 2013; Li 2014; Lee 2015; Warusevitane 2015; Chen 2016a; Du 2016i; Du 2016ii; Park 2016b; Vasant 2016).

- Allocation concealment was unclear in 28 studies (unclear risk of bias) (Bath 1997; Perez 1997; Liu 2000; Yuan 2003i; Yuan 2003ii; Liu 2004; Song 2004; Wei 2005; Power 2006; Bai 2007i; Bai 2007ii; Huang 2010; Jayasekeran 2010a; Jayasekeran 2010b; Khedr 2010; Kumar 2011; Xia 2011; Kang 2012; Kim 2012i; Kim 2012ii; Lee 2014; Zheng 2014; Heo 2015; Terre 2015; Park $2016 a$ (i); Park 2016a (ii); STEPS 2016; Xia 2016a).
- Two studies did not ensure allocation concealment (high risk of bias) (Jia 2006a; Lim 2009).

\section{Baseline prognostic factors matching between intervention and control groups}

- Baseline factors were similar in 34 studies (low risk of bias) (Perez 1997; Song 2004; Carnaby 2006i; Carnaby 2006ii; Bai 2007i; Bai 2007ii; Khedr 2009; Jayasekeran 2010b; Khedr 2010; Xia 2011; Chan 2012; Feng 2012; Kang 2012; Kim 2012i; Kim 2012ii; Park 2012; Park 2013; Shigematsu 2013; Lee 2014; Li 2014; Zheng 2014; Heo 2015; Lee 2015; Terre 2015; Warusevitane 2015; Chen 2016a; Du 2016i; Du 2016ii; Park 2016a (i); Park 2016a (ii); Park 2016b; STEPS 2016; Vasant 2016; Xia 2016a).

- Baseline factor matching was unclear in 13 studies (unclear risk of bias) (Bath 1997; Liu 2000; Yuan 2003i; Yuan 2003ii; Han 2004; Liu 2004; Wei 2005; Jia 2006a; Power 2006; Lim 2009; Huang 2010; Jayasekeran 2010a; Kumar 2011).

\section{Blinding}

\section{Performance bias}

- Both participants and investigators were blinded in three studies (low risk of bias) (Perez 1997; Kumar 2011; Warusevitane 2015).

- Participants were blinded in nine studies (low risk of bias) (Khedr 2009; Chan 2012; Park 2012; Park 2013; Terre 2015; Du 2016i; Du 2016ii; STEPS 2016; Vasant 2016).

- Both participants and investigators were unblinded in five studies (high risk of bias) (Carnaby 2006i; Carnaby 2006ii; Chen 2016a; Park 2016a (i); Park 2016a (ii)).

- Blinding of participants and investigators was uncertain in 14 studies (unclear risk of bias) (Bath 1997; Han 2004; Bai 2007i; Bai 2007ii; Lim 2009; Jayasekeran 2010a; Jayasekeran 2010b; Khedr 2010; Xia 2011; Shigematsu 2013; Li 2014; Lee 2015; Park 2016b; Xia 2016a). 


\section{Detection bias}

- Outcomes were blinded in 28 studies (low risk of bias) (Perez 1997; Han 2004; Wei 2005; Carnaby 2006i; Carnaby 2006ii; Khedr 2009; Lim 2009; Jayasekeran 2010a; Jayasekeran 2010b; Khedr 2010; Xia 2011; Chan 2012; Park 2012; Park 2013; Shigematsu 2013; Li 2014; Lee 2015; Terre 2015; Warusevitane 2015; Chen 2016a; Du 2016i; Du 2016ii; Park 2016a (i); Park 2016a (ii); Park 2016b; STEPS 2016; Vasant 2016; Xia 2016a).

- Outcomes were not blinded in three studies (high risk of bias) (Bath 1997; Bai 2007i; Bai 2007ii).

Overall, 16 studies did not report on any blinding procedures (i.e. for participants, investigators, or outcome assessors) (unclear risk of bias) (Liu 2000; Yuan 2003i; Yuan 2003ii; Liu 2004; Song 2004; Wei 2005; Jia 2006a; Power 2006; Huang 2010; Feng 2012; Kang 2012; Kim 2012i; Kim 2012ii; Lee 2014; Zheng 2014; Heo 2015).

\section{Incomplete outcome data}

- Ten studies reported no loss of participants during follow-up (low risk of bias) (Han 2004; Jayasekeran 2010a; Chan 2012; Kang 2012; Kim 2012i; Kim 2012ii; Park 2013; Shigematsu 2013; Lee 2014; Warusevitane 2015).

- Twelve studies reported loss of participants during follow-up, but we judged them to be at low risk of bias (Perez 1997; Carnaby 2006i; Carnaby 2006ii; Khedr 2009; Khedr 2010; Feng 2012; Park 2012; Du 2016i; Du 2016ii; Park 2016a (i); Park 2016a (ii); Vasant 2016).

- We judged seven studies to be at high risk of bias due to incomplete outcome data (Lim 2009; Jayasekeran 2010b; Li 2014; Lee 2015; Chen 2016a; Park 2016b; STEPS 2016).

- Loss of participants during follow-up was unclear in 18 studies (unclear risk of bias) (Bath 1997; Liu 2000; Yuan 2003i; Yuan 2003ii; Liu 2004; Song 2004; Wei 2005; Jia 2006a; Power 2006; Bai 2007i; Bai 2007ii; Huang 2010; Kumar 2011; Xia 2011; Zheng 2014; Heo 2015; Terre 2015; Xia 2016a).

- Data were not available for quality of life.

\section{Selective reporting}

- We judged 34 studies to be at low risk of reporting bias (Perez 1997; Carnaby 2006i; Carnaby 2006ii; Power 2006; Khedr 2009; Jayasekeran 2010a; Jayasekeran 2010b; Khedr 2010; Kumar 2011; Xia 2011; Chan 2012; Feng 2012; Kang 2012; Kim 2012i; Kim 2012ii; Park 2012; Park 2013; Shigematsu 2013; Lee 2014; Li 2014; Zheng 2014; Heo 2015; Lee 2015; Terre 2015; Warusevitane 2015; Chen 2016a; Du 2016i; Du 2016ii; Park 2016a (i); Park 2016a (ii); Park 2016b; STEPS 2016; Vasant 2016; Xia 2016a).

- In the remaining 13 studies, it was unclear if reported data were complete (unclear risk of bias) (Bath 1997; Liu 2000; Yuan 2003i; Yuan 2003ii; Han 2004; Liu 2004; Song 2004; Wei 2005; Jia 2006a; Bai 2007i; Bai 2007ii; Lim 2009; Huang 2010).

\section{Other potential sources of bias}

We assessed seven studies based on translations of the original text (Yuan 2003i; Yuan 2003ii; Song 2004; Wei 2005; Bai 2007i; Bai 2007ii; Huang 2010). Native Chinese speakers performed translations from Chinese to English.

We aggregated outcome data from dose escalation or comparison trials to form one active treatment group in one trial (Jayasekeran 2010b).

\section{Effects of interventions}

See: Summary of findings for the main comparison Swallowing therapy compared to placebo for dysphagia in acute and subacute stroke

\section{Summary of findings for main outcomes of swallowing therapy in general}

We entered the important outcomes in this review into Summary of findings for the main comparison, and we reported outcomes for 'swallowing therapy' versus 'no swallowing therapy'. This means that overall, for each outcome (e.g. length of inpatient stay), we combined several different interventions to test for efficacy. In this way, we have provided information on the effectiveness of swallowing therapy as a whole for each outcome. We assessed three additional outcomes (pharyngeal transit time, institutionalisation, and nutrition) but did not include them in Summary of findings for the main comparison (a maximum of seven outcomes are allowed); therefore, we did not assess the quality of studies for these outcomes using the GRADE approach, and we have not reported their outcomes in the main findings.

We also undertook subgroup analysis for each different type of intervention.

The number of outcomes reported varied considerably across studies.

- Primary outcome of death or dependency/disability at end of trial in one trial (split into two data sets).

- Case fatality at end of trial in 14 trials.

- Length of inpatient stay in eight trials.

- Proportion of patients with dysphagia at end of trial in 23 trials.

- Swallowing ability in 26 trials.

- Penetration aspiration score (PAS) in 11 trials.

- Chest infections or pneumonia in nine trials.

- Swallow timing in six trials.

- Nutrition in three trials.

- Institutionalisation in three trials.

\section{Primary outcome}

Functional outcome: death or dependency or death or disability at end of trial

Swallowing therapy had no effect on death or dependency, or death or disability, at end of trial (odds ratio (OR) $1.05,95 \%$ confidence interval (CI) 0.63 to $1.75 ; 306$ participants; 2 studies; $I^{2}=0 \% ; P=0.86$ : moderate-quality evidence; Analysis 1.1). One trial (two data sets) of behavioural interventions reported on this outcome.

\section{Secondary outcomes}

\section{Case fatality at end of trial}

Swallowing therapy had no effect on case fatality at end of trial (OR $1.00,95 \% \mathrm{Cl} 0.66$ to $1.52 ; 766$ participants; 14 studies; ${ }^{2}$ $=6 \% ; \mathrm{P}=0.99$ : moderate-quality evidence; Analysis 1.2). Trials of behavioural interventions, drug therapy, pharyngeal electrical stimulation, physical stimulation, and transcranial magnetic stimulation reported on this outcome. 


\section{Length of inpatient stay}

Swallowing therapy probably reduced length of inpatient stay (mean difference (MD) $-2.90,95 \% \mathrm{Cl}-5.65$ to -0.15 ; 577 participants; 8 studies; $I^{2}=11 \% ; P=0.04$ : moderate-quality evidence; Analysis 1.3). Trials of behavioural interventions and PES reported on this outcome. Subgroup analysis showed that the interventions did not differ (Analysis 1.3).

\section{Proportion of participants with dysphagia at end of trial}

Swallowing therapy probably reduced the proportion of participants with dysphagia at end of trial (OR $0.42,95 \% \mathrm{Cl} 0.32$ to $0.55 ; 1487$ participants; 23 studies; $\mathrm{I}^{2}=0 \% ; \mathrm{P}=0.00001$ : lowquality evidence; Analysis 1.4). Trials of acupuncture, behavioural interventions, drug therapy, NMES, PES, physical stimulation, and tDCS reported on this outcome. Subgroup analysis showed that acupuncture (OR $0.31,95 \% \mathrm{Cl} 0.20$ to $0.49 ; 676$ participants; 8 studies; $\left.\mathrm{I}^{2}=0 \% ; \mathrm{P}<0.00001\right)$ and behavioural interventions (OR $0.45,95 \% \mathrm{Cl} 0.28$ to $0.74 ; 511$ participants; 6 studies; $I^{2}=28 \% ; \mathrm{P}=$ $0.001)$ each reduced dysphagia but did not differ from each other $(P$ $=0.91$; Analysis 1.4).

\section{Swallowing ability}

Swallowing therapy probably improved swallowing ability (standardised mean difference (SMD) $-0.66,95 \% \mathrm{Cl}-1.01$ to -0.32 ; 1173 participants; 26 studies; $I^{2}=86 \% ; P=0.0002$ : very lowquality evidence; Analysis 1.5). Trials of acupuncture, behavioural interventions, drug therapy, NMES, PES, physical stimulation, tCDS, and TMS reported on this outcome. Subgroup analysis showed that behavioural interventions (SMD $-0.56,95 \% \mathrm{Cl}-1.07$ to $-0.05 ; 121$ participants; 3 studies; $I^{2}=47 \% ; P=0.03$ ) and TMS (SMD - $1.29,95 \%$ $\mathrm{Cl}-2.37$ to $-0.21 ; 141$ participants; 8 studies; $\mathrm{I}^{2}=85 \% ; \mathrm{P}=0.02$ ) each improved swallowing ability but did not differ from each other $(P=$ 0.09; Analysis 1.5). Review authors noted moderate to substantial heterogeneity between trials (Analysis 1.5).

\section{Penetration aspiration score}

Swallowing therapy did not significantly reduce aspiration assessed as penetration aspiration score (SMD $-0.37,95 \% \mathrm{Cl}-0.74$ to $-0.00 ; 303$ participants; 11 studies; $I^{2}=46 \% ; P=0.05$ : low-quality evidence; Analysis 1.6). Trials of behavioural interventions, NMES, PES, and TMS reported on this outcome. However, given that results show no overall benefit, we have not commented on subgroup analysis (Analysis 1.6).

\section{Chest infection or pneumonia}

Swallowing therapy probably reduced the incidence of chest infection or pneumonia (OR $0.36,95 \% \mathrm{Cl} 0.16$ to $0.78 ; 618$ participants; 9 studies; $\mathrm{I}^{2}=59 \% ; \mathrm{P}=0.009$ : very low-quality evidence; Analysis 1.7). Trials of behavioural interventions, drug therapy, NMES, and PES reported on this outcome. Subgroup analysis showed that drug therapy (OR $0.06,95 \% \mathrm{Cl} 0.01$ to 0.21 ; 60 participants; 1 study; $I^{2}$ not applicable; $\mathrm{P}<0.0001$ ) significantly reduced the incidence of chest infection or pneumonia at end of trial - a result that differed significantly from other interventions ( $P$ $=0.008$; Analysis 1.7).

\section{Pharyngeal transit time (PTT)}

Swallowing therapy may have reduced PTT (MD $-0.23,95 \% \mathrm{Cl}-0.32$ to $-0.15 ; 187$ participants; 6 studies; $I^{2}=29 \% ; \mathrm{P}<0.00001$; Analysis 1.8). Trials of drug therapy, NMES, PES, and physical stimulation reported on this outcome. Subgroup analysis showed that NMES (MD $-0.23,95 \% \mathrm{Cl}-0.39$ to $-0.08 ; 126$ participants; 3 studies; $\mathrm{I}^{2}=$ $63 \% ; P=0.003$; Analysis 1.8 ) and physical stimulation in one small study (MD $-0.19 ; 95 \% \mathrm{Cl}-0.34$ to $-0.04 ; 16$ participants; 1 study; $\mathrm{I}^{2}$ not applicable; $\mathrm{P}=0.01$ ) each reduced PTT but did not differ from each other, i.e. these findings are likely due to chance and not-significant. ( $P=0.98$; Analysis 1.8).

\section{Institutionalisation}

Swallowing therapy did not reduce the incidence of institutionalisation (OR $0.75,95 \% \mathrm{Cl} 0.47$ to $1.19 ; 447$ participants; 3 studies; $I^{2}=0 \% ; P=0.22$; Analysis 1.9 ). Trials of behavioural interventions and pharyngeal electrical stimulation reported on this outcome.

\section{Nutrition (albumin)}

Swallowing therapy did not reduce nutrition (MD 0.37, 95\% Cl -1.5 to $2.24 ; 169$ participants; 3 studies; $I^{2}=0 \% ; P=0.70$; Analysis 1.10). Trials of behavioural interventions and pharyngeal electrical stimulation reported on this outcome.

\section{Detailed subgroup analysis: summary of findings per type of intervention}

Not all interventions addressed all outcomes. We have reported available data.

\section{Acupuncture}

Acupuncture resulted in significant results (i.e. $<1.0$ ) for reducing the proportion of participants with dysphagia at end of trial. However, these findings may be due to chance, given that testing for subgroup differences did not yield significant results. Acupuncture did not reduce swallowing ability. Data on the effects of acupuncture on other outcomes were not available.

- Proportion of participants with dysphagia at end of trial (OR $0.31,95 \% \mathrm{Cl} 0.20$ to $0.49 ; 676$ participants; 8 studies; $\mathrm{I}^{2}=0 \% ; \mathrm{P}<$ 0.00001; Analysis 1.4).

- Swallowing ability (SMD $-0.55,95 \% \mathrm{Cl}-1.20$ to $0.11 ; 496$ participants; 6 studies; $\left.I^{2}=91 \% ; P=0.10\right)$. We noted significant heterogeneity (Analysis 1.5).

\section{Behavioural interventions}

Behavioural interventions produced significant results (i.e. $<1.0$ ) for improving swallowing ability and reducing the proportion of participants with dysphagia at the end of the trial. However, both of these findings may be due to chance, given that testing for subgroup differences for each outcome did not yield significant results. Although behavioural interventions also reduced penetration aspiration score (i.e. $<1.0$ ), results show no overall benefit for this outcome and this finding is likely due to chance. Behavioural interventions did not reduce length of inpatient stay, chest infection or pneumonia, case fatality at end of trial, functional outcome, institutionalisation, or nutrition. Behavioural interventions addressed more outcomes when compared with most interventions.

- Swallowing ability (SMD $-0.56,95 \% \mathrm{Cl}-1.07$ to $-0.05 ; 121$ participants; 3 studies; $\mathrm{I}^{2}=47 \% ; \mathrm{P}=0.03$; Analysis 1.5 ). 
- Proportion of participants with dysphagia at end of trial (OR $0.45,95 \% \mathrm{Cl} 0.28$ to $0.74 ; 511$ participants; 6 studies; $I^{2}=28 \%$; $P$ $=0.001$; Analysis 1.4).

- Penetration aspiration score (SMD $-0.88,95 \% \mathrm{Cl}-1.68$ to $-0.08 ; 27$ participants; 1 study; $\mathrm{I}^{2}$ not applicable; $\mathrm{P}=0.03$; Analysis 1.6$)$.

- Length of inpatient stay (MD $-2.70,95 \% \mathrm{Cl}-5.68$ to $0.28 ; 370$ participants; 4 studies; $\mathrm{I}^{2}=19 \% ; \mathrm{P}=0.08$; Analysis 1.3 ).

- Chest infection or pneumonia (OR $0.56,95 \% \mathrm{Cl} 0.31$ to $1.00 ; 473$ participants; 6 studies; $\mathrm{I}^{2}=21 \% ; \mathrm{P}=0.05$; Analysis 1.7 ).

- Case fatality at end of trial (OR $0.83,95 \% \mathrm{Cl} 0.46$ to $1.51 ; 306$ participants; 2 studies; $I^{2}=0 \% ; P=0.54$; Analysis 1.2).

- Functional outcome (OR $1.05,95 \% \mathrm{Cl} 0.63$ to $1.75 ; 306$ participants; 2 studies; $I^{2}=0 \% ; P=0.86$; Analysis 1.1).

- Institutionalisation (OR $0.76,95 \% \mathrm{Cl} 0.39$ to $1.48 ; 306$ participants; 2 studies; $I^{2}=12 \% ; P=0.42$; Analysis 1.9).

- Nutrition (albumin) (MD $0.20,95 \% \mathrm{Cl}-4.77$ to $5.17 ; 64$ participants; 2 studies; $I^{2}=0 \% ; P=0.94$; Analysis 1.10).

\section{Drug therapy}

Drug therapy was probably effective for reducing chest infection or pneumonia in one study - a result that differed from those of other interventions. Drug therapy did not improve swallowing ability, nor did it reduce case fatality, proportion of participants with dysphagia at end of trial, or pharyngeal transit time. Data on effects of drug therapy on other outcomes were not available.

- Chest infection or pneumonia (OR $0.06,95 \% \mathrm{Cl} 0.01$ to $0.21 ; 60$ participants; 1 study; $I^{2}$ not applicable; $\mathrm{P}<0.0001$; Analysis 1.7 ).

- Swallowing ability (SMD $-0.46,95 \% \mathrm{Cl}-0.93$ to $0.01 ; 71$ participants; 1 study; $I^{2}$ not applicable; $\mathrm{P}=0.06$; Analysis 1.5 ).

- Case fatality (OR $1.40,95 \% \mathrm{Cl} 0.31$ to $6.28 ; 148$ participants; 3 studies; $I^{2}=70 \% ; P=0.66$; Analysis 1.2).

- Proportion of participants with dysphagia at end of trial (OR $0.48,95 \% \mathrm{Cl} 0.07$ to $3.35 ; 17$ participants; 1 study; $\mathrm{I}^{2}$ not applicable; $\mathrm{P}=0.46$; Analysis 1.4 ).

- Pharyngeal transit time (MD $-0.21,95 \% \mathrm{Cl}-0.91$ to $0.49 ; 17$ participants; 1 study; $\left.\right|^{2}$ not applicable; $\mathrm{P}=0.56$; Analysis 1.8 ).

\section{Neuromuscular electrical stimulation (NMES)}

NMES was probably effective for reducing pharyngeal transit time (i.e. < 1.0). NMES did not reduce the proportion of participants with dysphagia at end of trial or penetration aspiration score, and did not improve swallowing ability.

- Pharyngeal transit time (MD $-0.23,95 \% \mathrm{Cl}-0.39$ to $-0.08 ; 126$ participants; 3 studies; $\mathrm{I}^{2}=63 \% ; \mathrm{P}=0.003$; Analysis 1.8 ).

- Proportion of participants with dysphagia at end of trial (OR $0.51,95 \% \mathrm{Cl} 0.18$ to $1.49 ; 76$ participants; 2 studies; $\mathrm{I}^{2}=7 \% ; \mathrm{P}=$ 0.22; Analysis 1.4).

- Penetration aspiration score (SMD $0.57,95 \% \mathrm{Cl}-0.38$ to $1.52 ; 18$ participants; 1 study; $\mathrm{I}^{2}$ not applicable; $\mathrm{P}=0.24$; Analysis 1.6 ).

- Swallowing ability (SMD $-1.34,95 \% \mathrm{Cl}-3.39$ to $0.71 ; 100$ participants; 2 studies; $I^{2}=93 \% ; P=0.20$; Analysis 1.5 ).

\section{Pharyngeal electrical stimulation (PES)}

PES studies addressed many outcomes but did not show an effect for case fatality, length of inpatient stay, proportion of participants with dysphagia at end of trial, swallowing ability, penetration aspiration score, chest infection or pneumonia, pharyngeal transit time, institutionalisation, or nutrition.

- Case fatality (OR $0.92,95 \% \mathrm{Cl} 0.38$ to $2.26 ; 215$ participants; 4 studies; $I^{2}=0 \% ; P=0.86$; Analysis 1.2 ).

- Length of inpatient stay (MD $-6.05,95 \% \mathrm{Cl}-16.40$ to $4.31 ; 207$ participants; 4 studies; $I^{2}=27 \%$; $=0.25$; Analysis 1.3).

- Proportion of participants with dysphagia at end of trial (OR $0.55,95 \% \mathrm{Cl} 0.15$ to $2.11 ; 66$ participants; 3 studies; $\mathrm{I}^{2}=0 \% ; \mathrm{P}=$ 0.39 ; Analysis 1.4)

- Swallowing ability (SMD $0.06,95 \% \mathrm{Cl}-0.22$ to $0.34 ; 194$ participants; 3 studies; $I^{2}=0 \% ; P=0.69$; Analysis 1.5).

- Penetration aspiration score (SMD $-0.17,95 \% \mathrm{Cl}-0.53$ to $0.19 ; 177$ participants; 4 studies; $I^{2}=12 \% ; P=0.35$; Analysis 1.6).

- Chest infection (OR 0.43, 95\% Cl 0.06 to $3.09 ; 28$ participants; 1 study; $I^{2}$ not applicable; $P=0.40$; Analysis 1.7 ).

- Pharyngeal transit time (MD $-0.15,95 \% \mathrm{Cl}-0.67$ to $0.37 ; 28$ participants; 1 study; $I^{2}$ not applicable; $\mathrm{P}=0.56$; Analysis 1.8$)$.

- Institutionalisation (OR $0.73,95 \% \mathrm{Cl} 0.36$ to $1.48 ; 141$ participants; 1 study; $I^{2}$ not applicable; $\mathrm{P}=0.38$; Analysis 1.9 ).

- Nutrition (MD 0.40; 95\% Cl-1.62 to 2.42; 105 participants; 1 study; $\mathrm{I}^{2}$ not applicable; $\mathrm{P}=0.70$; Analysis 1.10 ).

\section{Physical stimulation (thermal, tactile)}

Physical stimulation reduced pharyngeal transit time in one small study (i.e. < 1.0). However, these findings may be due to chance, given that testing for subgroup differences did not yield significant findings.

Physical stimulation had no effect on case fatality at end of trial nor on proportion of participants with dysphagia at end of trial and did not improve swallowing ability.

- Pharyngeal transit time (MD $-0.19,95 \% \mathrm{Cl}-0.34$ to $-0.04 ; 16$ participants; 1 study; $I^{2}$ not applicable; $P=0.01$; Analysis 1.8 ).

- Case fatality at end of trial (OR $1.05,95 \% \mathrm{Cl} 0.16$ to $6.92 ; 19$ participants; 1 study; $I^{2}$ not applicable; $P=0.96$; Analysis 1.2 ).

- Proportion of participants with dysphagia at end of trial (OR $0.65,95 \% \mathrm{Cl} 0.07$ to $5.85 ; 127$ participants; 2 studies; $\mathrm{I}^{2}=0 \% ; \mathrm{P}$ = 0.70; Analysis 1.4)

- Swallowing ability (SMD $-0.30,95 \% \mathrm{Cl}-1.29$ to $0.68 ; 16$ participants; 1 study; I $^{2}$ not applicable; $\mathrm{P}=0.55$; Analysis 1.5 ).

\section{Transcranial direct current stimulation (tDCS)}

tDCS did not alter the proportion of participants with dysphagia at end of trial and did not improve swallowing ability. Data on other outcomes were not available.

- Proportion of participants with dysphagia at end of trial (OR $0.29,95 \% \mathrm{Cl} 0.01$ to $8.39 ; 14$ participants; 1 study; $\mathrm{I}^{2}$ not applicable; $\mathrm{P}=0.47$; Analysis 1.4 ).

- Swallowing ability (SMD $-0.33,95 \% \mathrm{Cl}-2.22$ to $1.56 ; 34$ participants; 2 studies; $\mathrm{I}^{2}=85 \% ; \mathrm{P}=0.73$; Analysis 1.5 ).

\section{Transcranial magnetic stimulation (TMS)}

TMS improved swallowing ability at end of trial (i.e. < 1.0), although this finding may be due to chance, given that testing for subgroup differences did not yield significant results. We also noted considerable heterogeneity. TMS did not alter case fatality at end of 
trial nor penetration aspiration score. Data on other outcomes were not available.

- Swallowing ability (SMD $-1.29,95 \% \mathrm{Cl}-2.37$ to $-0.21 ; 141$ participants; 8 studies $=8 ; I^{2}=85 \% ; P=0.02$; Analysis 1.5 ).

- Case fatality at end of trial (OR $0.28,95 \% \mathrm{Cl} 0.03$ to $2.93 ; 78$ participants; 4 studies; $I^{2}=0 \% ; P=0.29$; Analysis 1.2).

- Penetration aspiration score (SMD $-0.53,95 \% \mathrm{Cl}-1.22$ to $0.16 ; 81$ participants; 5 studies; $I^{2}=51 \% ; P=0.13$; Analysis 1.6).

In summary, acupuncture, behavioural interventions, and TMS appeared to be individually effective for reducing some outcomes. However, as results of testing for subgroup differences were not significant, none of these interventions are convincingly different from the summary result. Drug therapy was the only intervention that was significantly less than 1.0 , and findings were significantly different for testing of subgroup differences, although this result was based on very low-quality evidence.

\section{DISCUSSION}

\section{Summary of main results}

We included 41 studies in this updated review of swallowing therapy in people with stroke. We identified 22 additional studies that are ongoing (Characteristics of ongoing studies), along with 86 studies that are awaiting classification (Characteristics of studies awaiting classification).

Researchers assessed eight types of stimulatory techniques acupuncture, behavioural therapy, drug therapy, neuromuscular electrical stimulation (NMES), pharyngeal electrical stimulation (PES), physical stimulation, transcranial direct current stimulation (tDCS), and transcranial magnetic stimulation (TMS). Swallowing therapy had no effect on functional outcomes (death or dependency, or death or disability), although only one trial reported this outcome (two data sets). Swallowing therapy also had no effect on case fatality at end of trial, nor on penetration aspiration score. However, swallowing therapy probably reduced length of inpatient stay, the proportion of participants with dysphagia at end of trial, and the incidence of chest infection or pneumonia (with one study reporting significant effects for drug therapy). Swallowing therapy also probably improved swallowing ability. In the absence of significant effects on the primary outcome, statistically significant findings in secondary and explanatory outcomes are hypothesis-generating and might reflect chance, for example, due to multiple-comparison testing. Hence, further trials are needed to test these observations.

\section{Overall completeness and applicability of evidence}

Results of this review are incomplete at this time because of the significant number of ongoing studies and those awaiting classification identified by review authors. Nevertheless, the addition of new studies to this version of the review has tightened confidence intervals, although the overall conclusion that dysphagia treatment does not alter functional outcome has not changed.

\section{Quality of the evidence}

The quality of evidence ranged from very low and low through moderate to high, as presented in Summary of findings for the main comparison. The most common reasons for reduced quality of evidence were lack of blinding, moderate to considerable heterogeneity between trials, and lack of precision (i.e. inclusion of multiple different interventions).

\section{Potential biases in the review process}

Results of the present analysis are subject to several caveats. First, we combined different interventions together for analysis, to assess whether trial results show any effect of swallowing therapy as a whole as opposed to no intervention or usual care. This means that decisions on which specific types of interventions are effective cannot be made upon analysis of these data. Future reviews will focus on assessing effects of specific interventions on main outcomes. Second, we excluded 80 studies from the analysis. One common reason for exclusion is that studies compared two active treatments without including a control or placebo group. We also excluded trials due to lack of uniformity in usage of outcome measures and lack of data on clinical outcomes, such as dependency, mortality, institutionalisation, and chest infection or pneumonia. Further, included trials used various swallowing assessment techniques, cortical excitability techniques, and videofluoroscopic measurements. So, trialists are encouraged to design future trials that include a control or placebo group, and to incorporate standard outcome measures. Third, a further 86 studies are awaiting assessment, subject to the availability of full-text articles; such omission of multiple studies will inevitably bias review results. Fourth, with regard to acupuncture, data from three studies may have been confounded due to use of 'routine' acupuncture or a different type of acupuncture as control, variation in delivery of therapy, and risk of language bias, in that some of the acupuncture literature is available in full only in Chinese language journals. Similarly, we included data from an NMES study (Park 2012), which considered sensory stimulation as a control; therefore we cannot be certain that this trial is not confounded. Last, the present analysis included only studies up to six months from stroke onset, and the effects of later treatments for post-stroke dysphagia remain unclear.

It is important to note that many trials are ongoing and should add substantially to the existing data once complete.

\section{Agreements and disagreements with other studies or reviews}

This is the largest, most inclusive, and most up-to-date review on this topic. It combines all current interventions for dysphagia in the acute and subacute phases of stroke. A number of separate systematic reviews exploring individual interventions for stroke survivors have been published, including some examining acupuncture in stroke (Xie 2008; Long 2012; Wong 2012), behavioural interventions in neurogenic dysphagia (Ashford 2009), TMS in stroke and acquired brain injury (Yang 2015; Liao 2016; Momosaki 2016; Pisegna 2016), tDCS in stroke and acquired brain injury (Yang 2015; Momosaki 2016; Pisegna 2016), NMES in stroke and neurological impairment (Chen 2016; Ding 2016), and PES in stroke (Scutt 2015). However, these reviews have examined the efficacy of individual interventions, whereas the current review has examined the efficacy of swallowing therapy overall; hence direct comparisons are difficult to make. 


\section{AUTHORS' CONCLUSIONS}

\section{Implications for practice}

Information on effects of swallowing therapy on the primary outcome of death or dependency/disability continues to be insufficient. Although some swallowing therapies appear to have a beneficial effect on some outcomes, these results are based on lower-quality evidence. At present, clinical decisions cannot be based on reliable evidence from clinical trials.

\section{Implications for research}

On the basis of existing studies and the need to exclude many others, future trials should consider the following design issues.

- Patients: include only those who have post-stroke dysphagia, and limit recruitment to a particular temporal phase after stroke. Researchers must specify clearly the time from stroke onset to randomisation when reporting trials. Trialists should aim for larger numbers of participants, ideally from multiple centres.

- Comparator: in the absence of any proven treatment, the control group should receive only standard care, with the treatment group receiving standard care plus the intervention being tested.

- Outcomes: studies need to ensure that standardised outcome measures are used to allow comparison of trials. Functional outcome (death or dependency) should be included in future trials, as should the number of participants who develop chest infection or pneumonia, or who have signs of aspiration. Trials should include outcomes of relevance to health economics, such as length of inpatient stay and discharge to an institution, as well as quality of life outcomes (e.g. EuroQoL Group Quality of Life Questionnaire based on five dimensions (EuroQoL-5D), Swallowing Quality of Life Questionnaire (SWAL-QOL)).

- Methods: researchers should endeavour to examine common parameters (i.e. use similar methods), so that results can be compared more readily across different studies.
- Quality of research: trialists must report full information on randomisation, allocation concealment, blinding of treatment and outcome assessment, and attrition.

- Future research: further research is needed to discover which components of swallowing therapy are beneficial. A number of studies assessing interventions for dysphagia are ongoing (22 studies), and findings of these studies will add further information on this topic (Characteristics of ongoing studies). Several studies of mixed groups of chronic dysphagia have been done or are ongoing: a systematic review of these studies may further inform the management of acute and subacute dysphagia post stroke.

\section{ACKNOWLEDGEMENTS}

We thank the following people who were review authors in previous versions of this review.

- Version 1 (1999): Jean Kerr, Morwenna Collins, Cameron Sellars, and David Smithard; they variously contributed to searches, data extraction, analysis and interpretation of data, and updating of the review.

- Version 2 (2012): Jessica Beavan, Sharon Ellendar, and Chamilla Geeganage; they variously undertook searches, data extraction, and analysis and interpretation of data, and updated the review.

We thank the Cochrane Stroke Group for assistance in identifying trials and conducting searches, and their editors and external assessor for comments on the review. Several trialists and other interested healthcare staff reviewed the draft of the first version and made comments - we thank each of them: CGMI Baeten (Netherlands), MS Dennis (UK), BR Garon (USA), GJ Hankey (Australia), GKT Holmes (UK), PR Mills (UK), B Norton (UK), C Ormiston (USA), J Rosenbek (USA), and G Vanhooren (Belgium). We also thank $D$ Luo and $G$ Lan, who translated five of the papers from Chinese into English. Finally, we are grateful to the funding bodies that supported this research. Naturally any mistakes are our own. We would be very grateful to be informed of any completed or ongoing trials that are not listed in the review, and to know of outcome data from existing trials that have not been included. 


\section{R E F E R E N C E S}

\section{References to studies included in this review}

Bai 2007i \{published data only\}

Bai J, Li B, Wang Z, Gao W, Wang L. The role of different needling manipulation in adjusting swallow period obstacle of dysphagia after stroke. Zhongguo Zhenjiu 2007;27(1):35-7.

\section{Bai 2007ii \{published data only\}}

Bai J, Li B, Wang Z, Gao W, Wang L. The role of different needling manipulation in adjusting swallow period obstacle of dysphagia after stroke. Zhongguo Zhenjui 2007;27(1):35-7.

\section{Bath 1997 \{unpublished data only\}}

Bath PMW, Kerr J, Collins M. Factorial trial of swallowing versus conventional therapy, and PEG versus nasogastric tube feeding, in dysphagic patients with recent stroke. Data on file 1997.

\section{Carnaby 2006i \{published and unpublished data\}}

* Carnaby G, Hankey GJ, Pizzi J. Behavioural intervention for dysphagia in acute stroke: a randomised controlled trial. Lancet Neurology 2006;5:31-7.

Mann G, Baxter K, Hankey G, Davis B, Stewart-Wynne E. Treatment for swallowing disorders following acute stroke: a randomised controlled trial. Stroke Society of Australia Annual Scientific Meeting. 1997.

Mann G, Hankey G, Davis B, Stewart-Wynne E. Swallowing therapy after acute stroke study (STAASS): where are we now? Journal of Clinical Neuroscience 1999;6(3):281.

\section{Carnaby 2006ii \{published data only\}}

Carnaby G, Hankey GJ, Pizzi J. Behavioural interventions for dysphagia in acute stroke: a randomised controlled trial. Lancet Neurology 2006;5:31-7.

\section{Chan 2012 \{published data only\}}

Chan S, Or K, Sun W, Ng K, Lo S, Lee Y. Therapeutic effects of acupuncture for neurogenic dysphagia - a randomized controlled trial. Journal of Traditional Chinese Medicine 2012;32(1):25-30.

\section{Chen 2016a \{published data only\}}

* Chen L, Fang J, Ma R, Gu X, Chen L, Li J, et al. Additional effects of acupuncture on early comprehensive rehabilitation in patients with mild to moderate acute ischemic stroke: a multicenter randomized controlled trial. BMC Complementary and Alternative Medicine 2016;16:226.

Chen L, Fang J, Ma R, Froym R, Gu X, Li J, et al. Acupuncture for acute stroke: study protocol for a multicenter, randomized, controlled trial. Trials 2014;15:214.

\section{Du 2016i \{published data only\}}

Du J, Yang F, Liu L, Hu J, Cai B, Liu W, et al. Repetitive transcranial magnetic stimulation for rehabilitation of poststroke dysphagia: a randomized, double-blind clinical trial. Clinical Neurophysiology 2016;127:2907-13.
Du 2016ii \{published data only\}

Du J, Yang F, Liu L, Hu J, Cai B, Liu W, et al. Repetitive transcranial magnetic stimulation for rehabilitation of poststroke dysphagia: a randomized, double-blind clinical trial. Clinical Neurophysiology 2016;127:2907-13.

Feng 2012 \{published data only\}

Feng X, Hao W, Ding Z, Sui Q, Guo H, Fu J. Clinical study on tongyan spray for post-stroke dysphagia patients: a randomized controlled trial. Chinese Journal of Integrative Medicine 2012;18(5):345-9.

\section{Han 2004 \{published data only\}}

Han JC. An observation on the therapeutic effect of acupuncture for bulbar palsy after acute stroke. Henan Journal of Practical Nervous Diseases 2004;7(3):81-2.

Heo 2015 \{published data only\}

Heo SY, Kim KM. Immediate effects of kinesio taping on the movement of the hyoid bone and epiglottis during swallowing by stroke patients with dysphagia. Journal of Physical Therapy Science 2015;27:3355-7.

\section{Huang 2010 \{published data only\}}

Huang Z, Huang F, Yan HX, Min Y, Gao Y, Tan BD, et al. Dysphagia after stroke treated with acupuncture or electric stimulation: a randomized controlled trial. Zhongguo Zhen Jiu 2010;30(12):969-73.

\section{Jayasekeran 2010a \{published data only\}}

Jayasekeran V, Singh S, Tyrrell P, Michou E, Jefferson S, Mistry $S$, et al. Adjunctive functional pharyngeal electrical stimulation reverses swallowing disability after brain lesions. Gastroenterology 2010;138(5):1737-46.

\section{Jayasekeran 2010b \{published data only\}}

Jayasekeran V, Singh S, Tyrrell P, Michou E, Jefferson S, Mistry S, et al. Adjunctive functional pharyngeal electrical stimulation reverses swallowing disability after brain lesions. Gastroenterology 2010;138(5):1737-46.

\section{Jia 2006a \{published data only\}}

Jia H, Zhang Y. Treatment of 40 cases of post-apoplectic dysphagia by acupuncture plus rehabilitation exercise. Journal of Acupuncture and Tuina Science 2006;4(6):336-8.

Kang 2012 \{published data only\}

Kang J, Park R, Lee S, Kim J, Yoon S, Jung K. The effect of bedside exercise program on stroke patients with dysphagia. Annals of Rehabilitation Medicine 2012;26:512-20.

Khedr 2009 \{published data only\}

Khedr EM, Abo-Elfetoh N, Rothwell JC. Treatment of post-stroke dysphagia with repetitive transcranial magnetic stimulation. Acta Neurologica Scandinavica 2009;119(3):155-61.

\section{Khedr 2010 \{published data only\}}

Khedr EM, Abo-Elfetoh N. Therapeutic role of rTMS on recovery of dysphagia in patients with lateral medullary syndrome and 
brainstem infarction. Journal of Neurology Neurosurgery and Psychiatry 2010;81:495-9.

\section{Kim 2012i \{published data only\}}

Kim L, Chun MH, Kim BR, Lee SJ. Effect of repetitive transcranial magnetic stimulation on patients with brain injury and dysphagia. Annals of Rehabilitation Medicine 2011;35:765-71.

\section{Kim 2012ii \{published data only\}}

Kim L, Chun MH, Kim BR, Lee SJ. Effect of repetitive transcranial magnetic stimulation on patients with brain injury and dysphagia. Annals of Rehabilitation Medicine 2011;35:765-71.

Kumar 2011 \{published data only\}

* Kumar S, Wagner CW, Frayne C, Zhu L, Selim M, Feng W, et al. Noninvasive brain stimulation may improve stroke-related dysphagia: a pilot study. Stroke 2011;42(4):1035-40.

NCT01132066. Transcranial direct current stimulation (TDCS) for facilitating swallowing improvement after an acute unilateral hemispheric stroke. clinicaltrials.gov/show/NCT01132066 first received 27 May 2010).

\section{Lee 2014 \{published data only\}}

Lee KW, Kim SB, Lee JH, Lee SJ, Ri JW, Park JG. The effect of early neuromuscular electrical stimulation therapy in acute/ subacute ischemic stroke patients with dysphagia. Annals of Rehabilitation Medicine 2014;38(2):153-9.

\section{Lee 2015 \{published data only\}}

Lee JS, Chui PY, Ma HM, Auyeung TW, Kng C, Law T, et al. Does low dose angiotensin converting enzyme inhibitor prevent pneumonia in older people with neurologic dysphagia - a randomized placebo-controlled trial. Journal of the American Medical Directors Association 2015;16(8):702-7.

\section{Li 2014 \{published data only\}}

Li L, Shi J, Yin J, Qiao B, Li Y, Huang R. Study of transcutaneous neuromuscular electrical stimulation (VitalStim) therapy for post-stroke dysphagia. European Journal of Physical and Rehabilitation Medicine 2014;Jul:23.

Lim 2009 \{published data only\}

Lim KB, Lee HJ, Lim SS, Choi YI. Neuromuscular electrical and thermal-tactile stimulation for dysphagia caused by stroke: a randomized controlled trial. Journal of Rehabilitation Medicine 2009;41(3):174-8.

\section{Liu 2000 \{published data only\}}

Liu L. Acupuncture treatment of bulbar palsy - a report of 54 cases. Journal of Traditional Chinese Medicine 2000;20(1):30-2.

\section{Liu 2004 \{published data only\}}

Liu Y. Treatment of pseudobulbar paralysis by scalp acupuncture and sublingual needling. Journal of Traditional Chinese Medicine 2004;24(1):26-7.

\section{Park 2012 \{published data only\}}

Park J, Kim Y, Oh J, Lee H. Effortful swallowing training combined with electrical stimulation in post-stroke dysphagia: a randomized controlled study. Dysphagia 2012;27:521-7.

\section{Park 2013 \{published data only\}}

Park J, Oh J, Lee J, Yeo J, Ryu KH. The effect of $5 \mathrm{~Hz}$ highfrequency rTMS over contralesional pharyngeal motor cortex in post-stroke oropharyngeal dysphagia: a randomized controlled study. Neurogastroenterology and Motility 2013;25:324-e250.

Park 2016a (i) \{published data only\} Park E, Kim MS, Chang WH, Oh SM, Kim YK, Lee A, Kim Y. Effects of bilateral repetitive transcranial magnetic stimulation on poststroke dysphagia. Brain Stimulation 2017;10:75-82.

Park 2016a (ii) \{published data only\}

Park E, Kim MS, Chang WH, Oh SM, Kim YK, Lee A, Kim Y. Effects of bilateral repetitive transcranial magnetic stimulation on poststroke dysphagia. Brain Stimulation 2017;10:75-82.

Park 2016b \{published data only\}

Park JS, Oh DH, Chang MY, Kim KM. Effects of expiratory muscle strength training on oropharyngeal dysphagia in subacute stroke patients: a randomised controlled trial. Journal of Oral Rehabilitation 2016;43:364-72.

Perez 1997 \{published and unpublished data\}

* Perez I, Smithard DG, Davies H, Kalra L. Pharmacological treatment of dysphagia in stroke. Dysphagia 1998;13:12-6.

Smithard D, Perez I, Kalra L. Pharmacological treatment of dysphagia in stroke. Age and Ageing 1997;26 Suppl 1:40.

Smithard D, Perez I, Kalra L. Pharmacological treatment of dysphagia in stroke. Cerebrovascular Diseases 1997;7 Suppl 4:36.

\section{Power 2006 \{published data only\}}

Power ML, Fraser DH, Hobson A, Singh S, Tyrell P, Nicholson DA, et al. Evaluating oral stimulation as a treatment for dysphagia after stroke. Dysphagia 2006;21(1):49-55.

\section{Shigematsu 2013 \{published data only\}}

Shigematsu T, Fujishima I, Ohno K. Transcranial direct current stimulation improves swallowing function in stroke patients. Neurorehabilitation and Neural Repair 2013;27(4):363-9.

\section{Song 2004 \{published data only\}}

Song QL. Swallowing and ingesting training and nursing in patients with swallowing disorders after stroke. Chinese Journal of Clinical Rehabilitation 2004;8(19):3722-3.

\section{STEPS 2016 \{published data only\}}

* Bath PM, Scutt P, Love J, Clavé P, Cohen D, Dziewas R, et al. Pharyngeal electrical stimulation for treatment of dysphagia in subacute stroke: a randomized controlled trial. Stroke 2016;47:1562-70.

Love J, Bath PMW. A multi-centre, double blind, randomised controlled clinical investigation to validate the EPS1 device as a treatment for stroke-induced dysphagia: a study of Swallowing Treatment using Electrical Pharyngeal Stimulation (STEPS Study). Clinical Investigational Plan. Data on file 2012. 
Terre 2015 \{published data only\}

Terre R, Mearin F. A randomized controlled study of neuromuscular electrical stimulation in oropharyngeal dysphagia secondary to acquired brain injury. European Journal of Neurology 2015;22(4):687-e44.

\section{Vasant 2016 \{published data only\}}

Vasant D, Michou E, Tyrrell P, Jayasekeran V, Mistry S, O'Leary N, et al. Pharyngeal electrical stimulation (PES) In dysphagia post-acute stroke: a double-blind, randomised trial. Gut 2014;63(1):A31.

* Vasant, DH, Michou E, O'Leary N, Vail A, Mistry S, Hamdy S, et al. Pharyngeal electrical stimulation in dysphagia poststroke: a prospective, randomized single-blinded interventional study. Neurorehabilitation and Neural Repair 2016;30(9):866-75.

\section{Warusevitane 2015 \{published data only\}}

Warusevitane AB, Karunatilake DS, Sim J, Lally F, Roffe C. Safety and effect of metoclopramide to prevent pneumonia in patients with stroke fed via nasogastric tubes trial. Stroke 2015;46:454-60.

\section{Wei 2005 \{published data only\}}

Wei LL. Effect of shuiti acupoint injection with stellate ganglion block on swallow dysfunction after stroke. Chinese Journal of Clinical Rehabilitation 2005;9(9):106-7.

\section{Xia 2011 \{published data only\}}

Xia W, Zheng C, Lei Q, Tang Z, Hua Q, Zhang Y, et al. Treatment of post-stroke dysphagia by vitalStim therapy coupled with conventional swallowing training. Journal of Huazhong University of Science and Technology - Medical Sciences 2011;31(1):73-6.

\section{Xia 2016a \{published data only\}}

Xia W, Zheng C, Zhu, Tang Z. Does the addition of specific acupuncture to standard swallowing training improve outcomes in patients with dysphagia after stroke? A randomized controlled trial. Clinical Rehabilitation 2016;30(3):237-46.

\section{Yuan 2003i \{published data only\}}

Yuan ZH, Huang LL, Chen ZL. Coagulant and enteral nutrition agents in the rehabilitation of deglutition disorders for patients with acute stroke. Chinese Journal of Clinical Rehabilitation 2003;7(28):3834-5.

\section{Yuan 2003ii \{published data only\}}

Yuan MZ, Huang LR, Chen ZL. Coagulant and enteral nutrition agent in the rehabilitation of deglutition disorders for patients with acute stroke. Chinese Journal of Clinical Rehabilitation 2003;7(28):3834-5.

\section{Zheng 2014 \{published data only\}}

Zheng L, Li Y, Liu Y. The individualized rehabilitation interventions for dysphagia: a multidisciplinary case control study of acute stroke patients. International Journal of Clinical and Experimental Medicine 2014;7(10):3789-94.

\section{References to studies excluded from this review}

Akamatsu 2009 \{published data only\}

Akamatsu C, Ebihara T, Ishizuka S, Fujii M, Seki K, Arai H, et al. Improvement of swallowing reflex after electrical stimulation to lower leg acupoints in patients after stroke. Journal of the American Geriatric Society 2009;57(10):1959-60.

\section{Aoki 2016 \{published data only\}}

Aoki S, Hosomi N, Hirayama J, Nakamori M, Yoshikawa M, Nezu T, et al. The multidisciplinary swallowing team approach decreases pneumonia onset in acute stroke patients. PLOS ONE 2016;11(5):1-8.

Arai 2003 \{published data only\}

Arai T, Ekizawa K. Cabergoline and silent aspiration in elderly patients with stroke. Journal of the American Geriatrics Society 2003;51(12):1815.

Beom 2011 \{published data only\}

Beom J, Kim SJ, Han TR. Electrical stimulation of the suprahyoid muscles in brain-injured patients with dysphagia: a pilot study. Annals of Rehabilitation Medicine 2011;35:322-7.

Beom 2015 \{published data only\}

Beom J, Oh B, Choi KH, Kim W, Song YJ, You DS, et al. Effect of electrical stimulation of the suprahyoid muscles in brain-injured patients with dysphagia. Dysphagia 2015;30:423-9.

\section{Bülow 2008 \{published data only\}}

Bülow M, Speyer R, Baijens L, Woisard V, Ekberg O. Neuromuscular electrical stimulation (NMES) in stroke patients with oral and pharyngeal dysfunction. Dysphagia 2008;23(3):302-9.

\section{Byeon 2016 \{published data only\}}

Byeon $\mathrm{H}$, Koh HW. Comparison of treatment effect of neuromuscular electrical stimulation and thermal-tactile stimulation on patients with sub-acute dysphagia caused by stroke. Journal of Physical Therapy Science 2016;28:1809-12.

\section{Cai 2015 \{published data only\}}

Cai H, Ma B, Gao X, Gao H. Tongue acupuncture in treatment of post-stroke dysphagia. International Journal of Clinical and Experimental Medicine 2015;8(8):14090-4.

Chaudhuri 2006 \{published data only\}

Chaudhuri G, Brady S, Caldwell R. Electric stimulation for dysphagia flowing stroke: pilot data. Archives of Physical Medicine and Rehabilitation 2006;87(11):e51.

\section{Chen 2002 \{published data only\}}

Chen F, Zhang X. Tongue acupuncture therapy plus ice stimulation for treating 50 cases of dysphagia at the acute stage of sanguineous apoplexy. Henan Traditional Chinese Medicine 2002;22(2):59.

\section{Chen 2003 \{published data only\}}

Chen Y, Li SY, Wang Y. The impression on the deglutition disorders due to pseudobulbar palsy treated with 
electroacupuncture integrated rehabilitation. Chinese Journal of Clinical Rehabilitation 2003;7(3):430-1.

\section{ChiCTR-ONC-17012326 \{published data only\}}

ChiCTR-ONC-17012326. Therapeutic effect of acupuncture and rTMS for dysphagia after unilateral hemispheric stroke of pharyngeal stage: a multi-center cohort study. www.chictr.org.cn/showproj.aspx?proj=21029 (first received 10 August 2017)

\section{ChiCTR-TRC-14005233 \{published data only\}}

ChiCTR-TRC-14005233. The application for telemedicine in poststroke rehabilitation. www.chictr.org.cn/showprojen.aspx? proj=4343 (first received 16 September 2014).

\section{DePippo 1994 \{published data only\}}

DePippo KL, Holas MA, Reding MJ. Dysphagia therapy following stroke: a controlled trial. Neurology 1993;43:A234-5.

DePippo KL, Holas MA, Reding MJ, Lesser ML, Mandel FS. Dysphagia therapy following stroke: a controlled trial. Neurology 1992;42:249.

* DePippo KL, Holas MA, Reding MJ, Mandel FS, Lesser ML. Dysphagia therapy following stroke: a controlled trial. Neurology 1994;44:1655-60.

\section{Dou 2012 \{published data only\}}

Dou Z, Zu Y, Wen H, Wan G, Jiang L, Hu Y. The effect of different catheter balloon dilatation modes on cricopharyngeal dysfunction in patients with dysphagia. Dysphagia 2012;27:514-20.

\section{Ebihira 2004 \{published data only\}}

Ebihara T, Takahasi H, Ebihira S, Okazaki T, Sasaki T, Wabanto A, et al. Theophylline improved swallowing reflex in elderly nursing home patients. Jourmal of the American Geriatrics Society 2004;52(10):1787-8.

\section{Ebihira 2005 \{published data only\}}

Ebihara T, Takahashi H, Ebihara S, Okazaki T, Sasaki T, Watando A. Capsaicin trouche for swallowing dysfunction in older people. Journal of American Geriatrics Society 2005;53:824-8.

\section{El-Tamawy 2015 \{published data only\}}

El-Tamawy MS, Darwish MH, El-Azizib HS, Abdelalim AM, Taha SI. The influence of physical therapy on oropharyngeal dysphagia in acute stroke patients. Egyptian Journal of Neurology, Psychiatry and Neurosurgery 2015;52(3):201-5.

\section{Fraser 2002 \{published data only\}}

Fraser C, Power M, Hamdy S, Rothwell J, Hobday D, Hollander I, et al. Driving plasticity in human adult motor cortex is associated with improved motor function after brain injury. Neuron 2002;34(5):831-40.

\section{Freed 1996 \{published data only\}}

Freed M, Christian MO, Beytas EM, Tucker H, Kotton B. Electrical stimulation of the neck: a new effective treatment for dysphagia. Dysphagia 1996;11:159.
Freed 2001 \{published data only\}

Freed ML, Freed L, Chatburn RL, Christian M. Electrical stimulation for swallowing disorders caused by stroke. Respiratory Care 2001;46(5):466-74.

Hagg 2015 \{published data only\}

Hagg M, Tibbling L. Effect of oral IQoro ${ }^{\circledR}$ and palatal plate training in post-stroke, four-quadrant facial dysfunction and dysphagia: a comparison study. Acta Oto-Laryngologica 2015;135(9):962-8

\section{Inui 2017 \{published data only\}}

Inui Y, Kamakuyra Y, Fukada J, Yoneda M, Kataoka E, Usami Y, et al. Development of pyriform sinus suctioning programs for aspiration pneumonia prevention during the acute stroke. Dysphagia 2017;32:767-76.

\section{ISRCTN18137204 \{published data only\}}

* ISRCTN18137204. Benefit of PHAryngeal electrical STimulation for early de-cannulation in TRACheotomised stroke patients with neurogenic dysphagia: a prospective randomized single-blinded interventional study (PHAST TRAC study). www.isrctn.com/ISRCTN18137204 (first received 23 February 2015).

Minten J, van der Tweel I, Dziewas R, Bath PM, Hamdy S. Benefit of PHAryngeal electrical STimulation for early de-cannulation in TRACheotomised stroke patients with neurogenic dysphagia: a prospective randomised single-blinded interventional study (PHAST TRAC study). Data on file 2015.

\section{ISRCTN97286108 \{published data only\}}

ISRCTN97286108. Non-invasive brain stimulation for dysphagia after acute stroke. http://www.isrctn.com/ISRCTN97286108 (first received 2 April 2015).

\section{Jin 2014a \{published data only\}}

Jin HP, Wu QY, Zhang W, Xie JJ, Chen JC. Post-stroke dysphagia in chronic stage treated with magnetic-ball sticking therapy at the auricular points: a randomized controlled trial. Zhongguo Zhen Jiu 2014;34(1):9-14.

\section{KCT0001907 \{published data only\}}

KCT0001907. Effects of neuromuscular electrical stimulation according to electrode placement in stroke patients with dysphagia. cris.nih.go.kr/cris/en/search/search_result_st01.jsp? seq=6225 (first received 4 August 2015).

\section{Kikuchi 2014 \{published data only\}}

Kikuchi A, Seki T, Takayama S, Ishizuka S, Yaegashi N. Effect of press needles on swallowing reflex in older adults with cerebrovascular disease: a randomized double-blind controlled trial. Journal of the American Geriatrics Society 2014;62(12):2430-40.

\section{Kobayashi 1996 \{published data only\}}

Kobayashi H, Nakagawa T, Sekizawa K, Arai H, Sasaki H. Levodopa and swallowing reflex. Lancet 1996;348:1320-1. 
Kulnik 2015 \{published data only\}

Kulnik ST, Birring SS, Moxham J, Rafferty GF, Klara L. Does respiratory muscle training improve cough flow in acute stroke? Pilot randomized controlled trial. Stroke 2015;46:447-53.

\section{Kushner 2013 \{published data only\}}

Kushner DS, Peters K, Eroglu ST, Perless-Carroll M, JohnsonGreene D. Neuromuscular electrical stimulation efficacy in acute stroke feeding tube-dependent dysphagia during inpatient rehabilitation. American Journal of Physical Medicine and Rehabilitation 2013;92(6):486-95.

\section{Lan 2013 \{published data only\}}

Lan Y, Xu G, Dou Z, Wan G, Yu F, Lin T. Biomechanical changes in the pharynx and upper sphincter after modified balloon dilatation in brainstem stroke patients with dysphagia. Neurogastroenterology and Motility 2013;25:821-9.

\section{Logemann 2009 \{published data only\}}

Logemann JA, Rademaker A, Pauloski BR, Kelly A, StanglMcBreen C, Antinoja J, et al. A randomized study comparing the Shaker exercise with traditional therapy: a preliminary study. Dysphagia 2009;24(4):403-11.

\section{Ma 2014 \{published data only\}}

Ma FX, Cao GP, Li WL. Post-stroke dysphagia treated with acupoint injection combined with neural electrical stimulation. Zhongguo Zhenjiu 2014;34(12):1169-73.

\section{Ma 2015 \{published data only\}}

Ma JN, Wang ZL, Ning LN, Yang H, Xiong J. Observation on therapeutic effects of acupuncture combined with cutaneous electrical stimulation for dysphagia in patients with cerebral infarction. Chen Tzu Yen Chiu Acupuncture Research 2015;40(3):238-41.

\section{Maeda 2017 \{published data only\}}

Maeda K, Koga T, Akagi J. Interferential current sensory stimulation, through the neck skin, improves airway defense and oral nutrition intake in patients with dysphagia: a doubleblind randomized controlled trial. Clinical Interventions in Aging 2017;12:1879-86.

\section{Mao 2016 \{published data only\}}

Mao L, Li L, Mao Z, Han Y, Zhang X, Yao J, Li M. Therapeutic effect of acupuncture combining standard swallowing training for post-stroke dysphagia: a prospective cohort study. Chinese Journal of Integrative Medicine 2016;22(7):525-31.

\section{McCullough 2012 \{published data only\}}

McCullough GH, Kamarunas E, Mann GC, Schmidley JW, Robbins JA, Crary MA. Effects of Mendelsohn maneuver on measures of swallowing duration post-stroke. Topics in Stroke Rehabilitation 2012;19(3):234-43.

\section{McCullough 2013 \{published data only\}}

McCullough GH, Kim Y. Effects of the Mendelsohn maneuver on extent of hyoid movement and UES opening post-stroke. Dysphagia 2013;28:511-9.
Mepani 2009 \{published data only\}

Mepani R, Antonik S, Massey B, Kern M, Logemann J, Pauloski B, et al. Augmentation of deglutitive thyrohyoid muscle shortening by the shaker exercise. Dysphagia 2009;24:26-31.

\section{Messaggi-Sartor 2015 \{published data only\}}

Messaggi-Sartor M, Guillen-Solà A, Depolo M, Duarte E, Rodríguez DA, Barrera M, et al. Inspiratory and expiratory muscle training in subacute stroke - a randomized clinical trial. American Academy of Neurology 2015;85:564-72.

\section{Michou 2010 \{published data only\}}

* Michou E, Mistry S, Jefferson S, Singh S, Rothwell J, Hamdy S. Addressing oropharyngeal dysphagia post stroke with neurostimulation interventions: a pilot study. International Journal of Stroke 2010;5 Suppl 3:61-2.

Michou E, Mistry S, Jefferson S, Singh S, Hamdy SA. Preliminary study of neurostimulation based interventions in the treatment of chronic dysphagia post stroke. Gut 2010;59(1):A27.

Michou 2011 \{published data only\}

Michou E, Mistry S, Jefferson S, Singh S, Rothwell J, Tyrrell P, et al. Neurostimulation techniques benefit stroke patients with chronic oropharyngeal dysphagia: preliminary results from a randomised controlled study. Cerebrovascular Diseases 2011;31(Suppl 2):58.

\section{Nakamura 2013 \{published data only\}}

Nakamura T, Fujishima I. Usefulness of ice massage in triggering the swallow reflex. Journal of Stroke and Cerebrovascular Diseases 22;4:378-82.

\section{Nakayama 1998 \{published data only\}}

Nakayama K, Sekizawa K, Sasaki H. ACE inhibitor and swallowing reflex. Chest 1998;113(5):1425.

\section{Nam 2012 \{published data only\}}

$\mathrm{Nam} \mathrm{H}$, Beom J, Oh BM, Han BR. Kinematic analysis of hyoid bone and vocal cord after laryngeal electrical stimulation therapy in dysphagia. Neurorehabilitation and Neural Repair 2012;26(4):433.

\section{NCT00376506a \{published data only\}}

NCT00376506. A comparison of an implanted neuroprosthesis with sensory training for improving airway protection in chronic dysphagia. https://clinicaltrials.gov/ct2/show/NCT00376506 (first received 15 September 2006).

\section{NCT00376506b \{published data only\}}

NCT00376506. A comparison of an implanted neuroprosthesis with sensory training for improving airway protection in chronic dysphagia. clinicaltrials.gov/ct2/show/NCT00376506 (first received 15 September 2006).

\section{NCT01971320 \{published data only\}}

NCT01971320. Evaluation of transcutaneous electrical stimulation in post stroke dysphagia. clinicaltrials.gov/show/ NCT01971320 (first received 29 October 2013). 
Nishiyama 2010 \{published data only\}

Nishiyama Y, Abe A, Ueda M, Katsura K, Katayama Y. Nicergoline increases serum substance $P$ levels in patients with an ischaemic stroke. Cerebrovascular Diseases 2010;29(2):194-8.

\section{Ortega 2016 \{published data only\}}

Ortega O, Rofes L, Martin A, Arreola V, Lo I, Clave P. A comparative study between two sensory stimulation strategies after two weeks treatment on older patients with oropharyngeal dysphagia. Dysphagia 2016;31:706-16.

\section{Permsirivanich 2009 \{published data only\}}

Permsirivanich W, Tipchatyotin S, Wongchai M, Leelamanit V, Setthawatcharawanich S, Sathirapanya P, et al. Comparing the effects of rehabilitation swallowing therapy vs. neuromuscular electrical stimulation therapy among stroke patients with persistent pharyngeal dysphagia: a randomized controlled study. Journal of the Medical Association of Thailand 2009;92(2):259-65.

\section{Pownall 2008 \{published data only\}}

Pownall S, Enderby P, Hendra T, Marshall M. Are thickened fluids worth the trouble? A pilot RCT of dysphagia management. Proceedings of the 3rd UK Stroke Forum Conference. Harrogate, UK: The Stroke Association, 2008:86-7.

\section{Pryor 2011 \{published data only\}}

Pryor J, Leonard R, Belafsky P. A prospective, randomized trial of two dysphagia therapies: neuromuscular electrical stimulation and vibrotactile stimulation. Dysphagia 2011;26(4):466.

\section{Reidnauer 2006 \{published data only\}}

Reidnauer S, Repsher S, Stryker D, Segal M. Vital stimulation may be more effective than traditional treatment in improving swallowing after stroke. Stroke 2006;37(2):737.

\section{Rofes 2014 \{published data only\}}

Rofes L, Arreola V, Martin A, Clave P. Effect of oral piperine on the swallow response of patients with oropharyngeal dysphagia. Journal of Gastroenterology 2014;29:1517-23.

\section{Rosenbek 1991 \{published data only\}}

Rosenbek JC, Robbins J, Fishback B, Levine RL. Effects of thermal application on dysphagia after stroke. Journal Speech and Hearing Research 1991;34:1257-68.

\section{Rosenbek 1996 \{published data only\}}

Rosenbek JC. Effects of thermal stimulation on dysphagia after stroke. Journal of Rehabilitation Research and Development 1990;28(1):151.

* Rosenbek JC, Roecker EB, Wood JL, Robbins J. Thermal application reduces the duration of stage transition in dysphagia after stroke. Dysphagia 1996;11:225-33.

\section{Rosenbek 1998 \{published data only\}}

Rosenbek JC, Robbins JA, Willford WO, Kirk G, Schiltz A, Sowell TW, et al. Comparing treatment intensities of tactilethermal application. Dysphagia 1998;13:1-9.

\section{Sdravou 2012 \{published data only\}}

Sdravou K, Walshe M. Effects of carbonated liquids on oropharyngeal swallowing measures in people with neurogenic dysphagia. Dysphagia 2012;27:240-50.

\section{Seki 2005 \{published data only\}}

Seki T, Iwasaki K, Arai H, Sasaki H, Hayashi H, Yamada S, et al. Acupuncture for dysphagia in post stroke patients: a video fluoroscopic study. Journal of the American Geriatrics Society 2005;53(6):1083-4.

\section{Shaker 2002a \{published data only\}}

Easterling C, Kern M, Nitschke T, Grande B, Kazandijan M, Dikeman K, et al. Restoration of oral feeding in 17 tube fed patients by the Shaker exercise. Dysphagia 2000;15(2):105.

* Shaker R, Easterling C, Kern M, Nitschke T, Massey B, Daniels $S$, et al. Rehabilitation of swallowing by exercise in tubefed patients with pharyngeal dysphagia secondary to abnormal UES opening. Gastroenterology 2002;122:1314-21.

\section{She 2014 \{published data only\}}

She RP, Ge CH. Clinical observation on medulla oblongata palsy after brainstem infarction treated with electroacupuncture at eight-neck-occiput points. Zhongguo Zhen Jiu 2014;34(6):539-42.

\section{SQACU01 2001 \{published data only\}}

Heng D. SQACU01 - a randomised trial of acupuncture as adjuvant therapy for dysphagia due to recent stroke. Clinical Trials and Epidemiology Research Unit Annual Report. Singapore: Clinical Trials and Epidemiology Research Unit, 2001:41.

\section{Steele 2016 \{published data only\}}

Steele CM. Tongue pressure profile training for dysphagia post stroke (TPPT): study protocol for an exploratory randomized controlled trial. Trials 2013; Vol. 14:126.

* Steele CM, Bayley MT, Peladeau-Pigeon M, Nagy A, Namasivayam AM, Stokely S, et al. A randomized trial comparing two tongue-pressure resistance training protocols for post-stroke dysphagia. Dysphagia 2016;31:452-61.

Sukthankar 1994 \{published data only\}

Sukthankar SM, Reddy NP, Canilang EP, Stephenson L, Thomas R. Design and development of portable biofeedback systems for use in oral dysphagia rehabilitation. Medical Engineering and Physics 1994;16:430-5.

\section{Suntrup 2015 \{published data only\}}

DRKS00005509. A single-centre, double blind, randomised controlled clinical trial to evaluate the effect of electrical pharyngeal stimulation as a treatment for stroke-related dysphagia in tracheotomized stroke patients. www.drks.de/ DRKS00005509 (first received 15 January 2014).

\footnotetext{
* Suntrup S, Marian T, Schröder JB, Suttrup I, Muhle P, Oelenberg $\mathrm{S}$, et al. Electrical pharyngeal stimulation for dysphagia treatment in tracheotomized stroke patients: a randomized controlled trial. Intensive Care Medicine 2015;41(9):1629-37.
} 


\section{Suzuki 2012 \{published data only\}}

Suzuki H, Takeda S, Nakazaki M, Sone S, Mori T. The appropriate body position during nasal-gastric tube feeding to prevent the aspiration pneumonia in acute stroke patients. Cerebrovascular Diseases 2012;33(2):464.

Tai 2014 \{published data only\}

* Tai S, Chang Y, Chang L. On the use of the chin-down posture for dysphagia in stroke patients. Cerebrovascular Diseases 2014;38:105

Tai S, Huang HM. The effectiveness of the chin-down posture in the improvement of dysphagia in stroke patients. http:// hdl.handle.net/10755/602716 (first received 21 March 2016).

\section{Teramoto 2008 \{published data only\}}

Teramoto S, Yamamoto H, Yamaguchi Y, Ishii M, Hibi S, Kume H. Antiplatelet cilostazol, an inhibitor of type III phosphodiesterase, improves swallowing function in patients with a history of stroke. Journal of the American Geriatrics Society 2008;56(6):1153-4.

\section{Terre 2012 \{published data only\}}

Terre R, Mearin F. Effectiveness of chin-down posture to prevent tracheal aspiration in dysphagia secondary to acquired brain injury. A videofluoroscopy study. Neurogastroenterology and Motility 2012;24:414.

\section{Toyama 2014 \{published data only\}}

* Toyama K, Matsumoto S, Kurasawa M, Setoguchi H, Noma T, Takenaka K, et al. Novel neuromuscular electrical stimulation system for treatment of dysphagia after brain injury. Neurologia Medico-Chirurgica 2014;54:521-8.

UMIN000015406. Effect of electrical stimulation in poststroke patients with dysphagia: a feasibility study. https:// upload.umin.ac.jp/cgi-open-bin/ctr_e/ctr_view.cgi? recptno=R000017918 (first received 10 October 2014)

Ueda 2004 \{published data only\} Ueda K, Yamada Y, Toyosata A, Nomura S, Saitho E. Effects of functional training of dysphagia to prevent pneumonia for patients on tube feeding. Gerontology 2004;21:108-11.

Varma 2006 \{published data only\}

Varma AK. The effect of motor control on oro-facial dysfunctions in stroke patients under Indian conditions; 5th World Stroke Congress; 2004 Jun 23-26; Vancouver, Canada. 2006;e319.

\section{Wang 2016 \{published data only\}}

Wang Z, Ma J, Ning L. Clinical observation of dysphagia after cerebral infarction treated with awn-like needle at Tiantu (CV 22). Chinese Acupuncture and Moxibustion 2016;36(10):1019-22.

\section{Xia 2016 \{published data only\}}

Xia W, Zheng C, Xia J, Zhang Y. Post-stroke dysphagia treated with acupuncture of meridian differentiation: a randomized controlled trial. Chinese Acupuncture and Moxibustion 2016;36(7):673-8.
Zhang 2011 \{published data only\}

Zhang ZL, Zhao SH, Chen GH, Ji XQ, Xue L, Yang YQ, et al. Randomized controlled study on dysphagia after stroke treated with deep insertion of Chonggu (EX-HN 27) by electroacupuncture. Zhongguo Zhen Jiu 2011;31(5):385-90.

\section{Zhang 2018a \{published data only\}}

Zhang L, Xu N, Li R, Wang L. Clinical study of electroacupuncture with different frequencies at Lianquan (CV 23) and Fengfu (GV 16) for stroke dysphagia. Chinese Acupuncture and Moxibustion 2018;38(2):115-9.

\section{Zhang 2018b \{published data only\}}

Zhang R, Ju X. Clinical improvement of nursing intervention in swallowing dysfunction of elderly stroke patients. Biomedical Research 2018;29(6):1099-102.

Zhao 2015 \{published data only\}

Zhao K, Wang Z, Cao W, Zhang Y, Song S, Kang W, et al. Therapeutic efficacy of swallowing neuromuscular electrical stimulation combined with acupuncture for post-stroke dysphagia. World Journal of Acupuncture-Moxibustion 2015;25(1):19-23.

\section{References to studies awaiting assessment}

Azimov 2017 \{published data only\}

Azimov A, Sadykov R, Rakhimbaeva G. Dopaminergic medicines can treat dysphagia in ischemic stroke. Journal of the Neurological Sciences 2017;381 Suppl 1:396.

\section{Carnaby 2012 \{published data only\}}

Carnaby G, LaGorio L, Crary M, Miller D. A randomized double blind trial of neuromuscular electrical stimulation + McNeill dysphagia therapy (MDTP) after stroke (ANSRS). Dysphagia 2012;27:569-620.

\section{Chang 2014 \{published data only\}}

Chang L, He PL, Zhou ZZ, Li YH. Efficacy observation of dysphagia after acute stroke treated with acupuncture and functional electric stimulation. Zhongguo Zhenjiu 2014;34(8):737-40.

\section{Chaudhuri 2008 \{published data only\}}

Chaudhuri G, Brady S, Caldwell R, Wesling M, Quill A. Neuromuscular electrical stimulation (NMES) for dysphagia treatment following acute ischaemic stroke. Dysphagia 2008;23(4):441.

\section{Chen 2017 \{published data only\}}

Chen D, Xing H Jiang Q, Xiang Y, Guo H. Role of levetiracetam in the rehabilitation of dysphagia due to stroke. International Journal of Pharmacology 2017;13(6):603-11.

\section{Cheng 2005 \{published data only\}}

Cheng XL, Zhao CS, Wang H, Ma L. Effects of early throat muscle training on vertebral-basilar artery blood flow in patients with pseudobulbar palsy. Chinese Journal of Clinical Rehabilitation 2005;9(25):17-9. 
Cheng 2014 \{published data only\}

Cheng FX, Chen T. Efficacy observation of post-stroke dysphagia treated with acupuncture at Lianquan (CV 23). Zhongguo Zhen Jiu 2014;34(7):627-30.

\section{ChiCTR-TRC-07000010 \{published data only\}}

ChiCTR-TRC-07000010. Randomized controlled study on the acupuncture for dysphagia in convalescence phase of apoplexy. http://www.chictr.org.cn/showprojen.aspx?proj=9515 (first received 6 February 2007).

\section{ChiCTR-TRC-08000463 \{published data only\}}

ChiCTR-TRC-08000463. Clinical evaluation of dysphagia therapeutic apparatus on cerebrovascular disease. Chinese Clinical Trial Registry (ChiCTR) www.chictr.org/ (first received 3 November 2008).

\section{ChiCTR-TRC-14004235 \{published data only\}}

ChiCTR-TRC-14004235. Clinical research of modified Dihuang Yinzi Decoction combined swallowing rehabilitation and videofluoroscopy on post-stroke dysphagia patients: a pilot trial. www.chictr.org/en/proj/show.aspx?proj=6601 (first received 20 January 2014).

\section{ChiCTR-TRC-14004955 \{published data only\}}

ChiCTR-TRC-14004955. Effect of transcranial direct current stimulation on dysphagia after stroke. http://www.chictr.org.cn/ showproj.aspx?proj=4618 (first received 16 July 2014).

\section{Choi 2017 \{published data only\}}

Choi J-B, Shim S-H, Yang J-E, Kim H-D, Lee D-H, Park J-S. Effects of Shaker exercise in stroke survivors with oropharyngeal dysphagia. NeuroRehabilitation 2017;41(4):753-7.

\section{Chu 2017 \{published data only\}}

Chu J, Liu X, Chen F, Hong F, Bao Y. Effects of GAO's neck acupuncture on swallowing function and quality of life in patients with post-stroke pseudobulbar palsy: a randomized controlled trial. Chinese Acupuncture and Moxibustion 2017;37(7):691-5.

\section{de Fraga 2017 \{published data only\}}

de Fraga BFD, Almeida STD, Santana MG, Cassol M. Efficacy of myofunctional therapy associated with voice therapy in the rehabilitation of neurogenic oropharyngeal dysphagia: a pilot study. International Archives of Otorhinolaryngology 2017;DOI:10.1055/s-0037-1605597:[Ref 27900].

\section{Eom 2017 \{published data only\}}

Eom M, Chang M, Oh D, Kim H, Han N, Park J. Effects of resistance expiratory muscle strength training in elderly patients with dysphagic stroke. Neuro Rehabilitation 2017;41(4):747-52.

\section{Erfmann 2017 \{published data only\}}

Erfmann, K. Effects of expiratory muscle strength training (EMST) on oropharyngeal dysphagia in subacute stroke patients: a randomised controlled trial. Journal of Clinical Practice in Speech-Language Pathology 2017;19(2):111.

\section{Fan 2007 \{published data only\}}

Fan C, Jiang H, Wu L. Clinical observations on acupuncture treatment of postapoplectic dysphagia. Shanghai Journal of Acupuncture and Moxibustion 2007;26:6-7.

Feng 2016 \{published data only\}

Feng S, Cao S, Du S, Yin T, Mai F, Chen X, et al. Acupuncture combined with swallowing training for post-stroke dysphagia: a randomized controlled trial. Zhongguo Zhen Jiu 2016;36(4):347-50

\section{Gao 2016 \{published data only\}}

Gao J, Zhang HJ. Effects of chin tuck against resistance exercise versus Shaker exercise on dysphagia and psychological state after cerebral infarction. European Journal of Physical and Rehabilitation Medicine 2016;53(3):426-32.

Guillen-Sola 2017 \{published data only\}

* Guillén-Solà A, Messagi Sartor M, Bofill-Soler N, Duarte E, Barrera MC, Marco E. Respiratory muscle strength training and neuromuscular electrical stimulation in subacute dysphagic stroke patients: a randomized controlled trial. Clinical Rehabilitation 2017;31(6):761-71.

Guillen-Sola A, Messagi-Sartor M, Barrera De Paz C, BofillSoler N, Rodriguez DA, Duarte E, et al. Effects of neuromuscular electrostimulation and respiratory muscle training in acute/ subacute dysphagic stroke patients. Retornus: a randomized control trial. Dysphagia 2015;30(2):236-7.

\section{Hamada 2017 \{published data only\}}

Hamada S, Yamaguchi H, Hiroyoshi H. Does sensory transcutaneous electrical stimulation prevent pneumonia in the acute stage of stroke? A preliminary study. International Journal of Rehabilitation Research 2017;40(1):94-6.

\section{Hong 2011 \{published data only\}}

Hong Z, Yulin W, Qin Y. Influence of diet nursing care on the prognosis of patients with poststroke dysphagia. Chinese Nursing Research 2011;25(1C):211-3.

\section{Huang 2008 \{published data only\}}

Huang YL, Liang FR, Chang HS, Hu KM, He J, Li N, et al. Effect of acupuncture on quality of life in post-ischemic stroke patients with dysphagia. Zhongguo Zhong Xi Yi Jie He Za Zhi 2008;28:505-8.

\section{Huang 2014 \{published data only\}}

*Huang K, Liu T, Huang Y, Leong C, Lin W, Pong Y. Functional outcome in acute stroke patients with oropharyngeal dysphagia after swallowing therapy. Journal of Stroke and Cerebrovascular Diseases 2014;23(10):2547-53.

NCT03048916. Dysphagia after different swallowing therapies. https://www.clinicaltrials.gov/ct2/show/record/NCT03048916 (first received 1 August 2010).

Huimin 2015 \{published data only\}

Huimin Z, Yongchao Y, Jiang R, Li L, Yao W, Weibo S, Jie Z. Effect of surface electromyographic biofeedback on the pharyngeal 
phase activities in patients with dysphagia after stroke. Chinese Journal of Cerebrovascular Diseases 2015;12(11):572-6.

\section{Jefferson 2008 \{published data only\}}

Jefferson S, Hamdy S, Michou E, Mistry S, Singh S. Neurostimulation is able to increase cortical bulbar excitability following dysphagic stroke. Proceedings of the 3rd UK Stroke Forum Conference; 2008 Dec 2-4. Harrogate: The Stroke Association, 2008.

\section{Jia 2006 \{published data only\}}

Jia H-L, Zhang Y-C. Treatment of 40 cases of post-apoplectic dysphagia by acupuncture plus rehabilitation exercise. Journal of Acupuncture and Tuina Science 2006;4(6):336-8.

\section{Jiang 2014 \{published data only\}}

Jiang W, Tan B, Zhou Y, Jia G, Wu X, Jia L, et al. Clinical study on treatment of patients with dysphagia after stroke by improved Vitalstim electroacupuncture. Journal of Shanghai Jiaotong University (Medical Science) 2014;34(9):1361-4.

\section{Jing 2016 \{published data only\}}

Jing Q, Yang X, Reng Q. Effect of neuromuscular electrical stimulation in patients with post-stroke dysphagia. Medical Science Technology 2016;57:1-5.

\section{Ji-Ye 2017 \{published data only\}}

Ji-Ye L. Influence of acupoint-injection on TXB2 and 6-ketoPGF1a in patients with pseudobulbar palsy: a randomized controlled trial. Journal of Acupuncture and Tuina Medicine 2017;1:22-6.

\section{Kim 2017 \{published data only\}}

Kim HD, Choi JB, Yoo SJ, Chang MY, Lee SW, Park JS. Tongueto-palate resistance training improves tongue strength and oropharyngeal swallowing function in subacute stroke survivors with dysphagia. Journal of Oral Rehabilitation 2017;44:59-64.

\section{Koch 2015 \{published data only\}}

Koch I, Meneghello F, Piccione F. Preliminary data of swallowing training using SEMG as biofeedback. Journal of the Neurological Sciences 2015;357:e353.

\section{Konecny 2018 \{published data only\}}

Konecny P, Elfmark M. Electrical stimulation of hyoid muscles in post-stroke dysphagia. Biomedical Papers of the Medical Faculty of the University Palacky Olomouc Czechoslovakia 2018;162(1):40-2.

\section{Koyama 2017 \{published data only\}}

Koyama Y, Sugimoto A, Hamano T, Kasahara T, Toyokura M, Masakado Y. Proposal for a modified jaw opening exercise for dysphagia: a randomized, controlled trial. Tokai Journal of Experimental and Clinical Medicine 2017;42(2):71-8.

\section{Lee 2015b \{published data only\}}

Lee JH, Kim SB, Lee KW, Lee SJ, Lee JU. Effect of repetitive transcranial magnetic stimulation according to the stimulation site in stroke patients with dysphagia. Annals of Rehabilitation Medicine 2015;39(3):432-9.

\section{Li 2008 \{published data only\}}

Li J, Li J. Acupuncture used to treat dysphagia induced by ischemic stroke. Journal of Beijing University of Traditional Chinese Medicine 2008;15:17-9.

\section{Li 2009 \{published data only\}}

Li H, Yue G, Liu D, Zhou H. Clinical observations on acupuncture plus rehabilitation training for improving postapoplectic dysphagia. Shanghai Journal of Acupuncture and Moxibustion 2009;28:388-9.

\section{Li 2016 \{published data only\}}

Li Y, Ren K, Xing R, Peng J, Zhang Z, Zhao J. Clinical research of the five needles combined with rehabilitation training treatment dysphagia after stroke. Pakistan Journal of Pharmaceutical Sciences 2016;29(5 Suppl):1745-8.

\section{Liu 2018 \{published data only\}}

Liu XP, Chen FY, Chu JM, Bao YH. Effects of nape acupuncture combined with swallowing rehabilitation on dysphagia in pseudobulbar palsy. Journal of Traditional Chinese Medicine 2018;38(1):117-24.

\section{Ma 2016 \{published data only\}}

Ma P, Xu S, Tian W, Duan H, Wang C, Shan Y, et al. Efficacy observation of post-stroke pseudo-bulbar palsy treated with quick needle insertion therapy at Aqiang point. Chinese Acupuncture and Moxibustion 2016;36(10):1027-30.

Malik 2017 \{published data only\}

Malik SN, Khan MSG, Ehsaan F, Tul-Ain Q. Effectiveness of swallow maneuvers, thermal stimulation and combination both in treatment of patients with dysphagia using functional outcome swallowing scale. Biomedical Research (India) 2017;28(4):1479-82.

\section{Mehndiratta 2017 \{published data only\}}

Mehndiratta MM, Gupta P, Kaur M. The effect of sensory-level electrical stimulation of the masseter muscle in early stroke patients with dysphagia. Neurology India 2017;65(4):743-5.

\section{Meng 2015 \{published data only\}}

Meng Y, Wang C, Shang S, Ning L, Zhou L, Han K. Effects of different acupuncture depths of Lianquan (CV 23) for dysphagia after stroke: a randomized controlled trial. Zhongguo Zhen Jiu 2015;35(10):990-4

\section{Meng 2018 \{published data only\}}

Meng P, Zhang S, Wang Q, Wang P, Han C, Gao J, Yue S. The effect of surface neuromuscular electrical stimulation on patients with post-stroke dysphagia. Journal of Back \& Musculoskeletal Rehabilitation 2018;31(2):363-70.

\section{Moon 2017 \{published data only\}}

Moon JH, Jung J, Won YS, Cho H, Cho K. Effects of expiratory muscle strength training on swallowing function in acute stroke patients with dysphagia. Journal of Physical Therapy Science 2017;29:609-12. 
Moon 2018 \{published data only\}

Moon JH, Hahm SC, Won YS, Cho HY. The effects of tongue pressure strength and accuracy training on tongue pressure strength, swallowing function, and quality of life in subacute stroke patients with dysphagia: a preliminary randomized clinical trial. International Journal of Rehabilitation Research 2018; Vol. 41, issue 3:204-10. [DOI: 10.1097/ MRR.0000000000000282]

\section{NCT00722111 \{published data only\}}

NCT00722111. Exercise for swallowing problems after stroke. https://clinicaltrials.gov/ct2/show/NCT00722111 (first received 25 July 2008).

\section{NCT01081444 \{published data only\}}

NCT01081444. Repetitive transcranial stimulation (rTMS) in post stroke dysphagia. clinicaltrials.gov/ct2/show/record/ NCT01081444?term=NCT01081444\&rank=1 (first received 5 March 2010).

\section{NCT01085903 \{published data only\}}

NCT01085903. Identifying and treating arousal related deficits in neglect and dysphagia. https://clinicaltrials.gov/ct2/show/ NCT01085903 (first received 12 March 2010).

\section{NCT01777672 \{published data only\}}

NCT01777672. Effect of afferent oropharyngeal pharmacological and electrical stimulation on swallow response and on activation of human cortex in stroke patients with oropharyngeal dysphagia (OD). A randomized controlled trial. clinicaltrials.gov/show/NCT01777672 (first received 29 January 2013).

\section{NCT02090231 \{published data only\}}

NCT02090231. The effect of repetitive transcranial magnetic stimulation for post-stroke dysphagia recovery. https:// clinicaltrials.gov/ct2/show/NCT02090231 (first received 18 March 2014).

\section{NCT02379182 \{published data only\}}

NCT02379182. Randomized controlled trial to evaluate the effect of vitalstim in patients with chronic post-stroke oropharyngeal dysphagia. clinicaltrials.gov/show/NCT02379182 (first received 4 March 2015).

\section{Nowicki 2003 \{published data only\}}

Nowicki NC, Averill A. Acupuncture for dysphagia following stroke. Medical Acupuncture 2003;14(3):17-9.

\section{Oshima 2009 \{published data only\}}

Oshima F, Takezawa H, Hamanaka M, Imai K, Makino M, Oda K, et al. Usefulness of nutritional management and swallowing training during the acute phase of cerebral infarction and the incidence rate of infection. Dysphagia 2009;24:453.

\section{Pan 2015 \{published data only\}}

Pan MZ, Chen J, Lin L. Effect of traditional Chinese medicine rehabilitation nursing on functional rehabilitation of dysphagia in stroke patients. Chinese Medicine Modern Distance Education of China 2015;13(23):107-9.
Park 2017 \{published data only\}

* Park JS, Hwang NK, Oh DH, Chang MY. Effect of head lift exercise on kinematic motion of the thyolaryngeal complex and aspiration in patients with dysphagic stroke. Journal of Oral Rehabilitation 2017;44:385-91.

KCT0001901. Effect of shaker exercise on motion of hyolaryngeal complex and aspiration in stroke patients with oropharyngeal dysphagia. http://cris.nih.go.kr/cris/en/search/ search_result_st01.jsp?seq $=6221$ (first received 30 October 2015).

Park 2018 \{published data only\}

Park J, An D, Oh D, Chang M. Effect of chin tuck against resistance exercise on patients with dysphagia following stroke: a randomized pilot study. NeuroRehabilitation 2018;42(2):191-7.

\section{Shao 2017 \{published data only\}}

Shao W-B, Wang Y, Jiang W-W, Tian L, Zhang J. Clinical study of columnar balloon dilatation therapy for severe dysphagia caused by upper esophageal sphincter achalasia after stroke. Chinese Journal of Contemporary Neurology and Neurosurgery 2017;17(3):185-91.

\section{Su 2010 \{published data only\}}

Su X, Lai X. The clinical study on "tongdutiaoshen" (an acupuncture treatment) for treatment of dysphagia after stroke. Journal of Clinical Acupuncture and Moxibustion 2010;26:3-6.

\section{Sun 2008 \{published data only\}}

Sun J, Mi Z, Wang H, Xu D, Chen H. Study on therapeutic effect of acupuncture on dysphagia after stroke. Journal of Rehabilitation Medicine 2008;169 Suppl 46:Abstract PP003-139.

\section{Sun 2018 \{published data only\}}

Sun D, Xu W, Chen N, Li S-M, Fu T. Clinical effectiveness of intradermal needle-embedding therapy for swallowing function in stroke patients with dysphagia. Acupuncture Research 2018;43(2):118-22.

\section{Suntrup-Krueger 2018 \{published data only\}}

NCT01970384. Transcranial direct current stimulation for dysphagia therapy in acute stroke patients. https:// clinicaltrials.gov/ct2/show/NCT01970384 (first received 28 October 2013).

* Suntrup-Krueger S, Ringmaier C, Muhle P, Wollbrink A, Kemmling A, Hanning $U$, et al. Randomized trial of transcranial direct current stimulation for poststroke dysphagia. Annals of Neurology 2018;83(2):328-40.

\section{Tageldin 2017 \{published data only\}}

Tageldin E, Khalil M, Bahnasy W, Fouda B. Evaluation of possible role of repetitive transcranial magnetic stimulation for dysphagic patients with brain stem infarction. Neurology 2017;88(16 Suppl 1):P5.156.

\section{Umay 2017 \{published data only\}}

Umay EK, Yaylaci A, Saylam G, Gundogdu I, Gurcay E, Akcapinar $D$, et al. The effect of sensory level electrical stimulation of the masseter muscle in early stroke patients with 
dysphagia: a randomized controlled study. Neurology India 2017;65(4):734-42.

\section{Wang 2010 \{published data only\}}

Wang Y. Clinical observation on cerebral stroke with dysphagia with treatment of combined traditional Chinese and west medicine. Heilongjiang Medicine Journal 2010;24:625-6.

\section{Wang 2014 \{published data only\}}

Wang Z, Song W, Qu Y, Huang X, Wang L. Efficacy of integrated swallowing function rehabilitation training in patients with nasal feeding during acute ischemic stroke. Chinese Journal of Cerebrovascular Diseases 2014;11(7):342-6.

Wang 2015 \{published data only\}

Wang Q. Clinical study on Tong Guan Li Qiao needling method for post-stroke deglutition disorders. Shanghai Journal of Acupuncture and Moxibustion 2015;34:721-3.

Wang 2017 \{published data only\}

Wang L, Qiu X, Ye LJ. Effects of rood intervention and routine oral intervention on malnutrition in stroke patients with dysphagia. World Chinese Journal of Digestology 2017;25(21):1980-4.

\section{Wei 2017 \{published data only\}}

Wei X, Yu F, Dai M, Xie C, Wan G, Wang Y, et al. Change in excitability of cortical projection after modified catheter balloon dilatation therapy in brainstem stroke patients with dysphagia: a prospective controlled study. Dysphagia 2017;32:645-56.

\section{Wu 2011 \{published data only\}}

Wu P, Liang F, Li Y, Yang L, Huang Y, Li A, et al. Clinical observation on acupuncture plus rehabilitation training for dysphagia after stroke - a multi-centered random-controlled trial. Journal of Traditional Chinese Medicine 2011;52:45-8.

\section{Wu 2013 \{published data only\}}

Wu YL, Wang L, Tuo S, Yu X, Wang Q. Clinical study on the effects of acupuncture kinesiotherapy for dysphagia caused by pseudobulbar paralysis after stroke. Chinese Journal of Rehabilitation Medicine 2013;28(8):739-42, 757.

Xia 2010 \{published data only\}

Xia W, Zheng C, Zhu S, Tang Z, Wang H, Hua Q, et al. Combination of feeding swallowing training and acupuncture: an effective rehabilitation method for dysphagia post stroke. Acta Med Univ Sci Technol Huazhong Journal of Huazhong University of Science and Technology. Medical Sciences 2010;39:614-9

\section{Xie 2011 \{published data only\}}

Xie Y, Liu H, Zhou W. Effect of acupuncture on dysphagia of convalescent stroke patients. Chinese Journal of Integrative Medicine 2011;31:736-40.

\section{Xu 2013 \{published data only\}}

Xu JY, Zhou ZL, Wu J. Clinical observation on the treatment of post-stroke dysphagia by Tiaoshen Tongluo Acupuncture combined with Tongue 3-needle and acupuncturing Double
Yifeng Acupoints. Journal of Zhejiang University of Traditional Chinese Medicine 2013;37(9):1117-8, 1132.

Xue 2004 \{published data only\}

Xue W. Early rehabilitation combined with acupuncture treatment on patients with allo-swallowing because of pseudomedulla oblongata paralysis after apoplexy. Chinese Journal of Composite Clinical Medicine 2004;6(12):25-6.

Yang 2008 \{published data only\}

Yang C, Lee J, Joo M, Shin Y. The effect of double application of functional electrical stimulation in patients with dysphagia after stroke. Journal of Rehabilitation Medicine 2008;169(Suppl 46):169-70 (Abstract PP003-142).

Yang 2012 \{published data only\} Yang EJ, Baek SR, Shin J, Lim JY, Jang HJ, Kim YK, et al. Effects of transcranial direct current stimulation (tDCS) on poststroke dysphagia. Restorative Neurology and Neuroscience. 2012;30(4):303-11.

\section{Zeng 2017 \{published data only\}}

Zeng Y, Yip J, Cui H, Guan L, Zhu H, Zhang W, et al. Efficacy of neuromuscular electrical stimulation in improving the negative psychological state in patients with cerebral infarction and dysphagia. Neurological Research 2018;40(6):473-9. [DOI: 10.1080/01616412.2018.1451015]

\section{Zhang 2007 \{published data only\}}

Zhang J, Zhao C, Jin M, Zhou Y, Wang C, Zhao X, et al. A new effective method for larynx elevation could avoid a special abnormal swallowing mode. Stroke 2007;38(2):571.

\section{Zhang 2015 \{published data only\}}

Zhang C. Analysis of Huoshe Liyan Decoction on treatment of 198 cases of stroke patients with dysphagia. Liaoning Journal of Traditional Chinese Medicine 2015;42:1436-8.

\section{Zhang 2016 \{published data only\}}

Zhang M, Tao T, Zhang ZB, Zhu X, Fan WG, Pu LJ, et al. Effectiveness of neuromuscular electrical stimulation on patients with dysphagia with medullary infarction. Archives of Physical Medicine and Rehabilitation 2016;97:355-62.

\section{Zhang 2017 \{published data only\}}

Zhang SY, Liu SB, Chen YM, Liao KL, Xiang Y, Pan D. Clinical trials for treatment of stroke patients with dysphagia by Vitalstim electroacupuncture combined with swallowing rehabilitation training. Acupuncture Research 2017;42(2):168-72.

\section{Zhen 2014 \{published data only\}}

Zhen $\mathrm{H}$. Clinical observations of treatments of poststroke deglutition dysfunction with acupuncture and electric stimulation. Physical Medicine and Rehabilitation 2014;6(8S2):S115.

\section{Zhong 2003 \{published data only\}}

Zhong C-M, Rong G, He F-Z, Jin H-Y. Comparison of head and body acupuncture in the treatment of deglutition disorders in subacute period of stroke. Chinese Journal of Clinical Rehabilitation 2003;7(19):2706-7. 
Zhu 2015a \{published data only\}

Zhu H, Yang Y, Rao J, Liu L, Wang Y, Shao W, Zhang J. Effect of surface electromyographic biofeedback on the pharyngeal phase activities in patients with dysphagia after stroke. Chinese Journal of Cerebrovascular Diseases 2015;11:572-6.

Zhu 2015b \{published data only\}

Zhu Z Z, Cui LL, Yin MM, Yu Y, Wang HT. Effects of swallowing training combined with low -frequency electrical stimulation on dysphagia after ischemic stroke. Chinese Journal of Contemporary Neurology and Neurosurgery 2015;15(4):285-9.

\section{References to ongoing studies}

\section{ChiCTR1800014337 \{published data only\}}

ChiCTR1800014337. High frequency repetitive transcranial magnetic stimulation in the rehabilitation of poststroke swallowing disorder. http://www.chictr.org.cn/ showprojen.aspx?proj=23332 (first received 6 January 2018).

\section{ChiCTR1800015837 \{published data only\}}

ChiCTR1800015837. A randomized controlled clinical study on stroke with dysphagia with treatment of combined of traditional Chinese and West medicine. http:// www.chictr.org.cn/showprojen.aspx?proj=20656 (first received 24 April 2018).

\section{ChicTR-ICR-15006004 \{published data only\}}

ChiCTR-ICR-15006004. Clinical observation of YiShen-TongQiao acupuncture on pharyngeal dysphagia after stroke. http:// www.chictr.org.cn/showproj.aspx?proj=10470 (first received 25 February 2015).

\section{ChiCTR-IOR-17010505 \{published data only\}}

ChiCTR-IOR-17010505. Fire needle for patients with dysphagia caused by post-stroke pseudobulbar palsy: a randomized controlled clinical trial. http://www.chictr.org.cn/ showprojen.aspx?proj=17738 (first received 23 January 2017).

\section{ChiCTR-IOR-17011359 \{published data only\}}

ChiCTR-IOR-17011359. The study on the effect of electroacupuncture at Lianquan and Fengfu on one side of brain swallowing function. http://www.chictr.org.cn/showproj.aspx? proj=19078 (first received 11 May 2017).

\section{ChiCTR-IPC-14005435 \{published data only\}}

ChiCTR-IPC-14005435. Research on mechanism of central regulation of transcranial magnetic stimulation on post-stroke dysphagia patients. http://www.chictr.org.cn/showproj.aspx? proj=9785 (first received 17 October 2017).

\section{ChiCTR-ROC-17011673 \{published data only\}}

ChiCTR-ROC-17011673. Neuromodulation on post-stroke patients: a clinical control trial based on mapping swallowing musculature motor cortex. www.chictr.org.cn/showproj.aspx? proj=19921 (first received 16 June 2017).

\section{ISRCTN14124645 \{published data only\}}

ISRCTN14124645. Metoclopramide and selective oral decontamination for avoiding pneumonia after stroke. http://
www.isrctn.com/ISRCTN14124645 (first received 10 October 2016).

ISRCTN68981054 \{published data only\}

ISRCTN68981054. Treatment of dysphagia after stroke with He's santong needling method: a prospective randomized controlled study. http://www.isrctn.com/ISRCTN68981054 (first received 25 September 2017).

NCT01758991 \{published data only\}

NCT01758991. Improving swallowing after stroke with transcranial direct current stimulation (iSWAT). https:// clinicaltrials.gov/ct2/show/NCT01758991 (first received 1 January 2013).

NCT01919112 \{published data only\}

NCT01919112. Fostering eating after stroke with transcranial direct current stimulation. https://clinicaltrials.gov/ct2/show/ record/NCT01919112 (first received 8 August 2013).

NCT02322411 \{published data only\}

NCT02322411. Effects of device-facilitated isometric progressive resistance oropharyngeal (I-PRO) therapy on dysphagia related outcomes in patients post-stroke (StrokeStrong). clinicaltrials.gov/show/NCT02322411 (first received 23 December 2014)

\section{NCT02470078 \{published data only\}}

NCT02470078. Pharyngeal electrical stimulation for the treatment of post-extubation dysphagia in acute stroke. https:// clinicaltrials.gov/ct2/show/NCT02470078 (first posted 12 June 2015).

\section{NCT02576470 \{published data only\}}

Humbert IA, Vose A. Kinematic visual biofeedback is best when training novel swallowing behaviors in dysphagic patients after stroke. Stroke 2018;49:ATP150.

* NCT02576470. Applying motor learning principles to dysphagia rehabilitation. https://clinicaltrials.gov/ct2/show/ NCT02576470 (first received 15 October 2015).

\section{NCT02960737 \{published data only\}}

NCT02960737. Dysphagia evaluation after stroke - incidence and effect of oral screen intervention on swallowing dysfunction. clinicaltrials.gov/show/NCT02960737 (first received 10 November 2016)

\section{NCT03021252 \{published data only\}}

NCT03021252. Respiratory muscle training in stroke swallowing disorders RETORNUS-2. https://clinicaltrials.gov/ct2/show/ NCT03021252 (first received 13 January 2017).

NCT03247374 \{published data only\}

NCT03247374. Bio-feedback treatment versus standard treatment for dysphagic post-stroke patients: a randomized controlled trial (bio-feedback treatment for dysphagic poststroke patients (BIO_DYS)). https://clinicaltrials.gov/ct2/show/ NCT03247374 (first received 11 August 2017). 


\section{NCT03274947 \{published data only\}}

NCT03274947. The utility of cerebellar transcranial magnetic stimulation in the neurorehabilitation of dysphagia after stroke. https://clinicaltrials.gov/ct2/show/NCT03274947 (first received 7 September 2017).

\section{NCT03358810 \{published data only\}}

NCT03358810. Pharyngeal electrical stimulation evaluation for dysphagia after stroke (PhEED). https://clinicaltrials.gov/ct2/ show/NCT03358810 (first received 2 December 2017).

\section{NCT03499574 \{published data only\}}

NCT03499574. Feasibility study of biofeedback in dysphagia therapy post stroke. https://www.clinicaltrials.gov/ct2/show/ record/NCT03499574?id=NCT03499574\&rank=1 (first received 17 April 2018).

\section{PACTR201710002724163 \{published data only\}}

PACTR201710002724163. Effect of transcutaneous electrical nerve stimulation and conventional therapy in poststroke dysphagic patients: a randomized controlled trial. http://apps.who.int/trialsearch/Trial2.aspx? TrialID=PACTR201710002724163 (first received 26 October 2017)

\section{U1111-1188-0335 \{published data only\}}

U1111-1188-0335. Program of rehabilitation with therapeutic efficacy control in oropharyngeal dysphagia after stroke. www.ensaiosclinicos.gov.br/rg/RBR-33grwq/ (first received 26 September 2016).

\section{Additional references}

\section{Arnold 2016}

Arnold M, Liesirova K, Broeg-Morvay A, Meisterernst J, Schlager M, Mono M-L, et al. Dysphagia in acute stroke: incidence, burden and impact on clinical outcome. PLOS ONE 2016:11(2):e0148424.

\section{Ashford 2009}

Ashford J, McCabe D, Wheeler-Hegland K, Frymark T, Mullen R, Musson N, et al. Evidence-based systematic review: oropharyngeal dysphagia behavioral treatments. Part III. Impact of dysphagia treatments on populations with neurological disorders. Journal of Rehabilitation, Research and Development 2009;46(2):195-204

\section{Barer 1989}

Barer D. The natural history and functional consequences of dysphagia after hemisphere stroke. Journal of Neurology, Neurosurgery and Psychology 1989;52:236-41.

\section{Carnaby 2006}

Carnaby G, Hankey GJ, Pizzi J. Behavioural intervention for dysphagia in acute stroke: a randomised controlled trial. Lancet Neurology 2006;5:31-7.

\section{Chen 2016}

Chen YW, Chang KH, Chen HC, Liang WM, Wang YH, Lim YN. The effects of surface neuromuscular electrical stimulation on post- stroke dysphagia: a systemic review and meta-analysis. Clinical Rehabilitation 2016;30(1):24-35.

\section{Cohen 2016}

Cohen DL, Roffe C, Beavan J, Blackett B, Fairfield CA, Hamdy S, et al. Post stroke dysphagia: a review and design considerations for future trials. International Journal Stroke 2016;11(4):399-411.

\section{Ding 2016}

Ding R, Ma F. Effectiveness of neuromuscular electrical stimulation on dysphagia treatment in patients with neurological impairments - a systematic review and metaanalysis. Annals of Otolaryngology and Rhinology 2016;3(12):1151.

\section{Finestone 1996}

Finestone HM, Greene-Finestone LS, Wilson ES, Teasell RW. Prolonged length of stay and reduced functional improvement rate in malnourished stroke rehabilitation patients. Archives of Physical Medicine and Rehabilitation 1996;77:340-5.

\section{Gordon 1987}

Gordon C, Langton-Hewer R, Wade D. Dysphagia in acute stroke. BMJ 1987;295:411-4.

\section{Hamdy 1998}

Hamdy S, Aziz Q, Rothwell JC, Power M, Singh KD, Nicholson DA, et al. Recovery of swallowing after dysphagic stroke relates to functional reorganization in the intact motor cortex. Gastroenterology 1998;115(5):1104-12.

\section{Higgins 2011}

Higgins JPT, Altman DG. Chapter 8: Assessing risk of bias in included studies. In: Cochrane Handbook of Systematic Reviews of Interventions Version 5.1.0 (updated March 2011). The Cochrane Collaboration, 2011. Available from www.cochranehandbook.org.

\section{Hinchey 2005}

Hinchey JA, Shephard T, Furie K, Smith D, Wang D, Tonn S, the Stroke Practice Improvement Network Investigators. Formal dysphagia screening protocols prevent pneumonia. Stroke 2005;36:1972-6.

\section{Krival 2008}

Krival K, Pelletier C, Kelchner L. Effects of carbonate vs thin and thickened liquids on swallowing in adults with stroke. Dysphagia 2008;23:428.

\section{Lakshminarayan 2010}

Lakshminarayan K, Tsai AW, Tong X, Vazquez G, Peacock JM, George MG, et al. Utility of dysphagia screening results in predicting poststroke pneumonia. Stroke 2010;41(12):2849-54

\section{Lazarra 1986}

Lazarra G, Lazarus C, Logemann J. Impact of thermal stimulation on the triggering of the swallow reflex. Dysphagia 1986;1:73-7. 


\section{Liao 2016}

Liao X, Xing G, Guo Z, Jin Y, Tang Q, He B, et al. Repetitive transcranial magnetic stimulation as an alternative therapy for dysphagia after stroke: a systematic review and meta-analysis. Clinical Rehabilitation 2017;31(3):289-98.

\section{Logemann 1991}

Logemann J. Approaches to management of disordered swallowing. Clinical Gastroenterology 1991;5:269-80.

\section{Logemann 1993}

Logemann J. Non-invasive approaches to deglutitive aspiration. Dysphagia 1993;8:331-3.

\section{Long 2012}

Long Y-B, Wu X-P. A meta-analysis of the efficacy of acupuncture in treating dysphagia in patients with a stroke. Acupuncture in Medicine 2012;00:1-7.

\section{Mann 1999}

Mann G, Hankey GJ, Cameron D. Swallowing function after stroke: prognosis and prognostic factors at 6 months. Stroke 1999;30:744-8.

\section{Mann 2000}

Mann G, Hankey GJ, Cameron D. Swallowing disorders following acute stroke: prevalence and diagnostic accuracy. Cerebrovascular Diseases 2000;10:380-6.

\section{Martino 2005}

Martino R, Foley N, Bhogal S, Diamant N, Speechley M, Teasell R. Dysphagia after stroke: incidence, diagnosis, and pulmonary complications. Stroke 2005;36(12):2756-63.

\section{Mendelsohn 1987}

Mendelsohn MS, McConnell FM. Function in the pharyngoesophageal segment. Laryngoscope 1987;97(4):483-9.

\section{Momosaki 2016}

Momosaki R, Kinoshita S, Kakuda W, Yamada N, Abo M. Noninvasive brain stimulation for dysphagia after acquired brain injury. A systematic review. Journal of Medical Investigation 2016;63(3-4):153-8.

\section{Odderson 1995}

Odderson IR, Keaton JC, McKenna BS. Swallow management in patients on an acute stroke pathway: quality is cost effective. Archives of Physical Medicine and Rehabilitation 1995;76:1130-3.

\section{Perry 2004}

Perry L. Eating and dietary intake in communication impaired stroke survivors: a cohort study from acute stage hospital admission to 6 months post stroke. Clinical Nutrition 2004;23:1333-43.

\section{Pisegna 2016}

Pisegna JM, Kaneoka A, Pearson Jr WG, Kumar S, Langmore SE. Effects of non-invasive brain stimulation on post-stroke dysphagia: a systematic review and meta-analysis of randomized controlled trials. Clinical Neurophysiology 2016;127(1):956-68.

\section{Ramsey 2003}

Ramsey DJC, Smithard D, Kalra L. Early assessments of dysphagia and aspiration risk in acute stroke patients. Stroke 2003;34:1252-7.

\section{RevMan 2014 [Computer program]}

The Nordic Cochrane Centre, The Cochrane Collaboration. Review Manager (RevMan). Version 5.3. Copenhagen: The Nordic Cochrane Centre, The Cochrane Collaboration, 2014.

\section{Rofes 2013}

Rofes L, Vilardell N, Clavé P. Post-stroke dysphagia: progress at last. Neurogastroenterology and Motility 2013;25(4):278-82.

\section{Scutt 2015}

Scutt P, Lee HS, Hamdy S, Bath PM. Pharyngeal electrical stimulation for treatment of poststroke dysphagia: individual patient data meta-analysis of randomised controlled trials. Stroke Research and Treatment 2015;2015:1-8. [DOI: 10.1155/2015/429053]

\section{Shaker 2002}

Shaker R, Easterling C, Kern M, Nitschke T, Massey B, Daniels S, et al. Rehabilitation of swallowing by exercise in tube-fed patients with pharyngeal dysphagia secondary to abnormal UES opening. Gastroenterology 2002;122(5):1314-21.

\section{Sharma 2001}

Sharma JC, Fletcher S, Vassallo M, Ross I. What influences outcome after stroke - pyrexia or dysphagia?. International Journal of Clinical Practice 2001;55(1):17-20.

\section{Singh 2006a}

Singh S, Hamdy S. Dysphagia in stroke patients. Postgraduate Medical Journal 2006;82:383-91.

\section{Smithard 1993}

Smithard D, Kenwick D, Martin D, O'Neill P. Chest infection following acute stroke: does aspiration matter?. Age and Ageing 1993;22 Suppl 3:24-9.

\section{Smithard 1996}

Smithard DG, O'Neill PA, Park C, Morris J, Wyatt R, England R, et al. Complications and outcome after acute stroke. Does dysphagia matter?. Stroke 1996;27:1200-4.

\section{Smithard 1997}

Smithard DG, O'Neil PA, England RE, Park, CL, Wyatt, R, Martin DF, et al. The natural history of dysphagia following stroke. Dysphagia 1997;12(4):188-93.

\section{Theurer 2013}

Theurer JA, Johnston JL, Fisher J, Darling S, Stevens RC, Taves D, et al. Proof-of-principle pilot study of oropharyngeal air-pulse application in individuals with dysphagia after hemispheric stroke. Archives of Physical Medicine and Rehabilitation 2013;94(6):1088-94.

\section{Wolfe 1993}

Wolfe C, Taub N, Woodrow J, Richardson E, Warburton F, Burney P. Patterns of acute stroke care in three districts of 
southern England. Journal of Epidemiology and Community Health 1993;47:144-8.

\section{Wong 2012}

Wong ISY, Ng KF, Tsang HWH. Acupuncture for dysphagia following stroke: a systematic review. European Journal of Integrative Medicine. 2012;4(2):141-50.

\section{Xie 2008}

Xie Y, Wang L, He J, Wu T. Acupuncture for dysphagia in acute stroke. Cochrane Database of Systematic Reviews 2008, Issue 3. [DOI: 10.1002/14651858.CD006076.pub2]

\section{Yang 2015}

Yang SN, Pyun S-B, Kim HJ, Ahn HS, Rhyu BJ. Effectiveness of non-invasive brain stimulation in dysphagia subsequent to stroke: a systematic review and meta-analysis. Dysphagia 2015;30:383-91.

\section{Yuan 2003}

Yuan ZH, Huang LL, Chen ZL. Coagulant and enteral nutrition agents in the rehabilitation of deglutition disorders for patients with acute stroke. Chinese Journal of Clinical Rehabilitation 2003;7(28):3834-5.

\section{References to other published versions of this review \\ Bath 1999}

Bath PMW, Bath FJ, Smithard DG. Interventions for dysphagia in acute stroke. Cochrane Database of Systematic Reviews 1999, Issue 4. [DOI: 10.1002/14651858.CD000323]

\section{Geeganage 2012}

Geeganage C, Beavan J, Ellender S, Bath PMW. Interventions for dysphagia and nutritional support in acute and subacute stroke. Cochrane Database of Systematic Reviews 2012, Issue 10. [DOI: 10.1002/14651858.CD000323.pub2]

* Indicates the major publication for the study

\section{CHARACTERISTICS OF STUDIES}

Characteristics of included studies [ordered by study ID]

Bai $2007 \mathrm{i}$

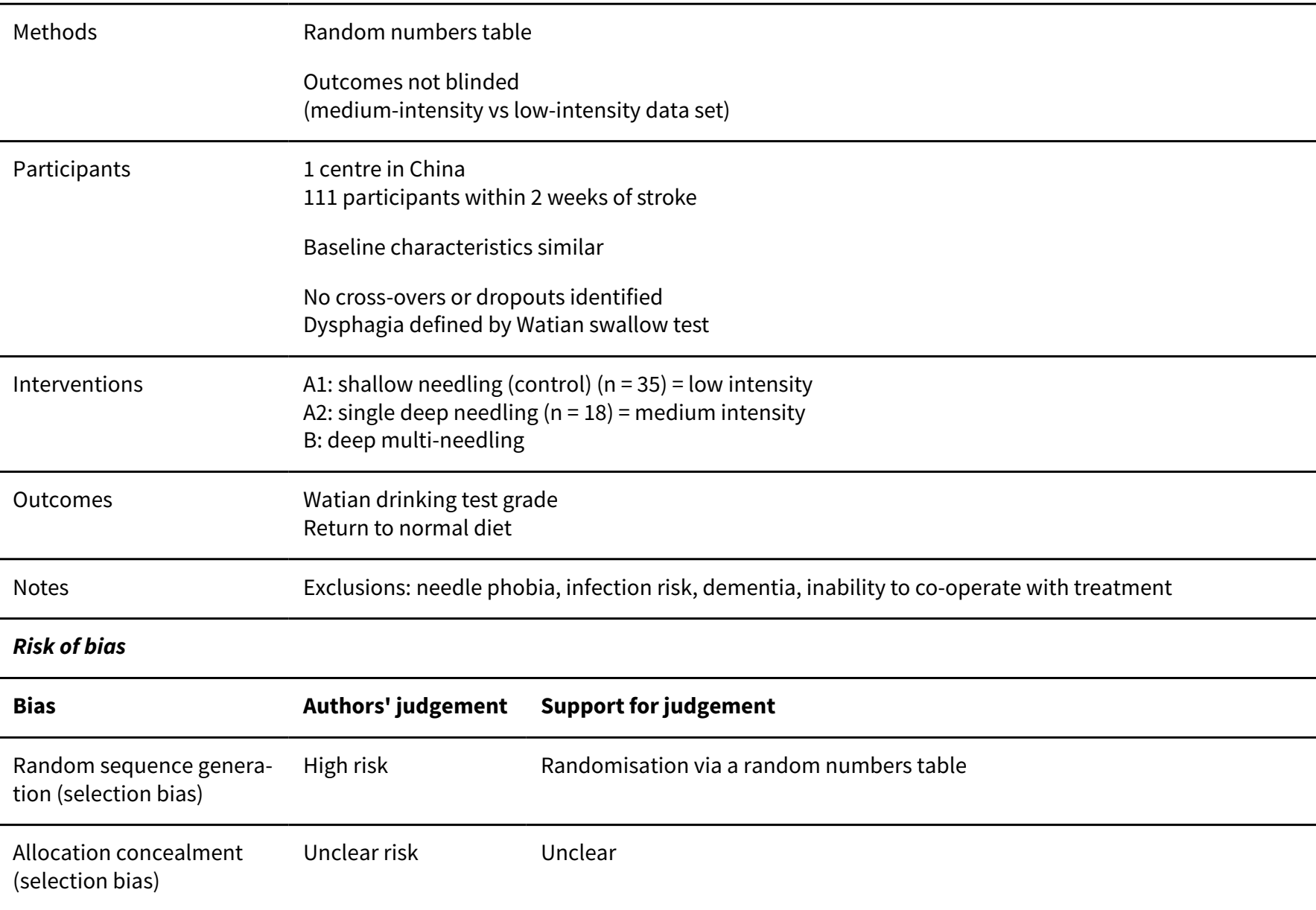


Bai 2007i (Continued)
Blinding (performance
Unclear risk
Unclear
bias and detection bias)
All outcomes

Blinding of participants Unclear risk Unclear
and personnel (perfor-
mance bias)
All outcomes

\begin{tabular}{|c|c|c|}
\hline $\begin{array}{l}\text { Blinding of outcome as- } \\
\text { sessment (detection bias) } \\
\text { All outcomes }\end{array}$ & High risk & Outcomes not blinded \\
\hline $\begin{array}{l}\text { Incomplete outcome data } \\
\text { (attrition bias) } \\
\text { All outcomes }\end{array}$ & Unclear risk & Unclear \\
\hline $\begin{array}{l}\text { Selective reporting (re- } \\
\text { porting bias) }\end{array}$ & Unclear risk & Unclear \\
\hline Other bias & Unclear risk & Translated from Chinese language \\
\hline
\end{tabular}

Bai 2007ii

\begin{tabular}{ll}
\hline Methods & (High vs medium data set) \\
\hline Participants & As data set 1 \\
\hline Interventions & $\begin{array}{l}\text { A1: shallow needling (control) } \\
\text { A2: single deep needling }(n=17)=\text { medium intensity } \\
\text { B: deep multi-needling }(n=40)=\text { high intensity }\end{array}$ \\
\hline Outcomes & As data set 1 \\
\hline Notes & - \\
\hline
\end{tabular}

\section{Risk of bias}

\begin{tabular}{lll}
\hline Bias & Authors' judgement & Support for judgement \\
\hline $\begin{array}{l}\text { Random sequence genera- } \\
\text { tion (selection bias) }\end{array}$ & High risk & Randomisation via a random numbers table \\
\hline $\begin{array}{l}\text { Allocation concealment } \\
\text { (selection bias) }\end{array}$ & Unclear risk & Unclear \\
\hline $\begin{array}{l}\text { Blinding (performance } \\
\text { bias and detection bias) } \\
\text { All outcomes }\end{array}$ & Unclear risk & Unclear \\
\hline $\begin{array}{l}\text { Blinding of participants } \\
\text { and personnel (perfor- } \\
\text { mance bias) } \\
\text { All outcomes }\end{array}$ & Unclear risk & Unclear \\
\hline
\end{tabular}


Bai 2007ii (Continued)

Blinding of outcome as-
sessment (detection bias) $\quad$ High risk $\quad$ Outcomes not blinded

All outcomes

\begin{tabular}{lll}
\hline $\begin{array}{l}\text { Incomplete outcome data } \\
\text { (attrition bias) } \\
\text { All outcomes }\end{array}$ & Unclear risk & Unclear \\
\hline $\begin{array}{l}\text { Selective reporting (re- } \\
\text { porting bias) }\end{array}$ & Unclear risk & Unclear \\
\hline Other bias & Unclear risk & Translated from Chinese \\
\hline
\end{tabular}

\section{Bath 1997}

\begin{tabular}{|c|c|}
\hline Methods & $\begin{array}{l}\text { Computerised randomisation by minimisation } \\
\text { Unblinded outcome assessment } \\
\text { Analysis by ITT } \\
\text { Cross-overs: } 3 \text { NGT to PEG, O PEG to NGT } \\
\text { Balancing of baseline prognostic factors between treatment groups unclear }\end{array}$ \\
\hline Participants & $\begin{array}{l}1 \text { centre in UK } \\
19 \text { participants: } 8 \text { male } \\
\text { Mean age } 77 \text { (SD 11) years } \\
13 \text { ischaemic stroke, } 6 \text { haemorrhagic stroke } \\
100 \% \text { CT } \\
\text { Enrolment within } 2 \text { weeks of stroke onset }\end{array}$ \\
\hline Interventions & $\begin{array}{l}\text { Factorial trial: PEG vs NGT; intensive vs conservative swallowing therapy } \\
\text { PEG: NGT: up to } 3 \text { NGTs } \\
\text { Intensive swallowing therapy: as for conservative, plus voluntary control (tongue-holding), sensory } \\
\text { stimulation (tactile, oromotor exercises, swallow practice) } \\
\text { Conservative swallowing therapy: review, advice regarding feeding route, postural/dietary modifica- } \\
\text { tion, safe swallowing methods }\end{array}$ \\
\hline Outcomes & $\begin{array}{l}\text { Primary outcomes: resumption of safe feeding at } 12 \text { weeks, weight loss }<5 \% \text { at } 6 \text { weeks, discharge by } 6 \\
\text { weeks } \\
\text { Secondary outcomes: impairment, disability, handicap, quality of life, tube failures, chest infection, } \\
\text { oropharyngeal delay time (by videofluoroscopy) at } 4 \text { weeks }\end{array}$ \\
\hline
\end{tabular}

\section{Notes}

Exclusions: oro-gastrointestinal disease, concurrent severe illness, coagulopathy, premorbid dependency, severe dementia, psychiatric illness

Follow-up: 3 months

\section{Risk of bias}

\begin{tabular}{lll}
\hline Bias & Authors' judgement & Support for judgement \\
\hline $\begin{array}{l}\text { Random sequence genera- } \\
\text { tion (selection bias) }\end{array}$ & Low risk & Computerised randomisation by minimisation \\
\hline $\begin{array}{l}\text { Allocation concealment } \\
\text { (selection bias) }\end{array}$ & Unclear risk & Unclear \\
\hline $\begin{array}{l}\text { Blinding (performance } \\
\text { bias and detection bias) }\end{array}$ & Unclear risk & Unclear \\
\hline
\end{tabular}


Bath 1997 (Continued)

All outcomes

Blinding of participants Unclear risk Unclear
and personnel (perfor-
mance bias)
All outcomes

Blinding of outcome as- High risk Unblinded outcome assessment

sessment (detection bias)

All outcomes

Incomplete outcome data Unclear risk Unclear
(attrition bias)
All outcomes

\begin{tabular}{lll}
\hline $\begin{array}{l}\text { Selective reporting (re- } \\
\text { porting bias) }\end{array}$ & Unclear risk & Unclear \\
\hline Other bias & Low risk & None identified \\
\hline
\end{tabular}

Carnaby 2006i

$\begin{array}{ll}\text { Methods } & \text { Computerised randomisation } \\ \text { Blinded outcome assessments by SLT } \\ \text { ITT } \\ \text { (Control vs low-intensity data set) } \\ \text { Baseline prognostic factors balanced between treatment groups } \\ \begin{array}{l}1 \text { centre in Australia } \\ \text { Participants }\end{array} \\ \text { Enrolment within } 2 \text { weeks of stroke onset: mean/median } 2 \text { days, range } 0 \text { to } 12 \text { days } \\ \text { Clinical and videofluoroscopic evidence of dysphagia }\end{array}$

Rx 1: standardised high-intensity swallowing therapy $(n=102)$
Rx 2: standardised low-intensity swallowing therapy $(n=102)$; split into $(n=51)$ for each data set
C: usual care $(n=102)$
Treatment for up to 1 month

Outcomes Outcomes: time to return to normal diet; aspiration pneumonia; dysphagia (PHAD score < 85)

\begin{tabular}{ll}
\hline Notes & Trial completed and published 2006 \\
& Exclusions: previous swallowing therapy, head and neck surgery, inability to consent \\
& Follow-up: 6 months
\end{tabular}

\section{Risk of bias}

\begin{tabular}{lll}
\hline Bias & Authors' judgement & Support for judgement \\
\hline $\begin{array}{l}\text { Random sequence genera- } \\
\text { tion (selection bias) }\end{array}$ & Low risk & $\begin{array}{l}\text { Treatment allocation based on a computer-generated random numbers list } \\
\text { generated via the SPSS statistical package }\end{array}$ \\
\hline
\end{tabular}


Carnaby 2006i (Continued)

Allocation concealment Low risk Randomisation schedule held at the trial office, remote from the study envi(selection bias) ronment; assignment to 1 of 3 treatment options by a telephone call to the trial office made by the study speech pathologist

\begin{tabular}{|c|c|c|}
\hline $\begin{array}{l}\text { Blinding (performance } \\
\text { bias and detection bias) } \\
\text { All outcomes }\end{array}$ & High risk & $\begin{array}{l}\text { All people involved in the study unaware of treatment allocation, apart from } \\
\text { participants and the study speech pathologist who treated participants } \\
\text { Assigned to high-intensity and low-intensity groups }\end{array}$ \\
\hline $\begin{array}{l}\text { Blinding of participants } \\
\text { and personnel (perfor- } \\
\text { mance bias) } \\
\text { All outcomes }\end{array}$ & High risk & Participants and speech pathologist aware of treatment allocation \\
\hline $\begin{array}{l}\text { Blinding of outcome as- } \\
\text { sessment (detection bias) } \\
\text { All outcomes }\end{array}$ & Low risk & $\begin{array}{l}\text { Outcome assessed by an independent speech pathologist, who was unaware } \\
\text { of treatment allocation, every month for } 6 \text { months after randomisation }\end{array}$ \\
\hline $\begin{array}{l}\text { Incomplete outcome data } \\
\text { (attrition bias) } \\
\text { All outcomes }\end{array}$ & Low risk & 3 participants lost to follow-up before 6 -month analysis \\
\hline $\begin{array}{l}\text { Selective reporting (re- } \\
\text { porting bias) }\end{array}$ & Low risk & All outcomes reported \\
\hline Other bias & Low risk & None identified \\
\hline
\end{tabular}

Carnaby 2006ii

\begin{tabular}{ll}
\hline Methods & (High-intensity vs low-intensity data set) \\
\hline Participants & As data set 1 \\
\hline Interventions & $\begin{array}{l}\text { High intensity }(n=102) \\
\text { Low intensity }(n=51)\end{array}$ \\
\hline Outcomes & As data set 1 \\
\hline Notes & - \\
\hline
\end{tabular}

\section{Risk of bias}

\begin{tabular}{lll}
\hline Bias & Authors' judgement & Support for judgement \\
\hline $\begin{array}{l}\text { Random sequence genera- } \\
\text { tion (selection bias) }\end{array}$ & Low risk & $\begin{array}{l}\text { Treatment allocation based on a computer-generated random numbers list } \\
\text { obtained via the SPSS statistical package }\end{array}$ \\
\hline $\begin{array}{l}\text { Allocation concealment } \\
\text { (selection bias) }\end{array}$ & Low risk & $\begin{array}{l}\text { Randomisation schedule held at trial office, remote from the study environ- } \\
\text { ment; assignment to } 1 \text { of } 3 \text { treatment options by a telephone call to the trial of- } \\
\text { fice made by the study speech pathologist }\end{array}$ \\
\hline $\begin{array}{l}\text { Blinding (performance } \\
\text { bias and detection bias) } \\
\text { All outcomes }\end{array}$ & High risk & $\begin{array}{l}\text { All people involved in the study unaware of treatment allocation, apart from } \\
\text { participants and the study speech pathologist who treated participants } \\
\text { Assigned to high-intensity and low-intensity groups }\end{array}$ \\
\hline
\end{tabular}


Carnaby 2006ii (Continued)

Blinding of participants High risk As above and personnel (performance bias)

All outcomes

\section{Blinding of outcome as- Low risk} sessment (detection bias) All outcomes
Outcome assessed by an independent speech pathologist, who was unaware of treatment allocation, every month for 6 months after randomisation

\begin{tabular}{lll}
\hline $\begin{array}{l}\text { Incomplete outcome data } \\
\text { (attrition bias) } \\
\text { All outcomes }\end{array}$ & Low risk & 3 participants lost to follow-up before 6-month analysis \\
\hline $\begin{array}{l}\text { Selective reporting (re- } \\
\text { porting bias) }\end{array}$ & Low risk & All outcomes reported \\
\hline Other bias & Unclear risk & None identified \\
\hline
\end{tabular}

\section{Chan 2012}

\begin{tabular}{ll}
\hline Methods & Randomisation by random sequences on black paper \\
& Single-blind (participants blinded): outcome assessors blinded \\
\hline Participants & 1 centre in Hong Kong \\
87 participants with neurogenic dysphagia with similar baseline characteristics \\
$60(69 \%)$ participants with dysphagia due to cerebral infarct < 6 months; other causes of neurogenic \\
dysphagia include intracranial haemorrhage, vascular dementia, Parkinson's disease \\
Clinical evidence of dysphagia
\end{tabular}

\begin{tabular}{ll}
\hline Interventions & All groups given routine swallowing therapy \\
& Rx 1: true acupuncture $(n=20)$ \\
Rx 2: sham acupuncture that did not puncture true acupoints lying on a meridian ( $\mathrm{n}=19)$ \\
C: routine swallowing therapy only $(\mathrm{n}=48)$ \\
Treatment for up to 4 weeks
\end{tabular}

\section{Risk of bias}

\begin{tabular}{lll}
\hline Bias & Authors' judgement & Support for judgement \\
\hline $\begin{array}{l}\text { Random sequence genera- } \\
\text { tion (selection bias) }\end{array}$ & Low risk & Randomisation by random sequences \\
\hline $\begin{array}{l}\text { Allocation concealment } \\
\text { (selection bias) }\end{array}$ & Low risk & Allocation concealed in opaque envelopes \\
\hline \hline
\end{tabular}


Chan 2012 (Continued)

Blinding (performance $\quad$ Low risk $\quad$ Single (participants) blinded
bias and detection bias)

All outcomes

Blinding of participants Low risk Single (participants) blinded
and personnel (perfor-
mance bias)
All outcomes

\begin{tabular}{|c|c|c|}
\hline $\begin{array}{l}\text { Blinding of outcome as- } \\
\text { sessment (detection bias) } \\
\text { All outcomes }\end{array}$ & Low risk & Outcome assessors blinded \\
\hline $\begin{array}{l}\text { Incomplete outcome data } \\
\text { (attrition bias) } \\
\text { All outcomes }\end{array}$ & Low risk & No losses to follow-up reported \\
\hline $\begin{array}{l}\text { Selective reporting (re- } \\
\text { porting bias) }\end{array}$ & Low risk & All outcomes reported \\
\hline Other bias & Low risk & None identified \\
\hline
\end{tabular}

Chen 2016a

\begin{tabular}{|c|c|}
\hline Methods & $\begin{array}{l}\text { Computer-generated random numbers by independent research staff } \\
\text { Assessors blinded }\end{array}$ \\
\hline Participants & $\begin{array}{l}\text { Multi-centre trial in China } \\
250 \text { participants; } 148 \text { male } \\
100 \% \text { stroke within } 2 \text { to } 7 \text { days } \\
\text { Dysphagia identified by bedside swallowing assessment and videofluoroscopic swallowing study } \\
\text { Baseline characteristics and prognostic values similar between both groups }\end{array}$ \\
\hline Interventions & $\begin{array}{l}\text { Rx: acupuncture and conventional stroke rehabilitation care } \\
\text { C: conventional stroke rehabilitation care only } \\
\text { Duration: } 3 \text { weeks } \\
\text { Follow-up: } 7 \text { weeks }\end{array}$ \\
\hline Outcomes & $\begin{array}{l}\text { Primary outcome: NIHSS index } \\
\text { Secondary outcomes: FMA for motor function, rate of recovery based on BSA, VFSS, MMSE, and MoCA }\end{array}$ \\
\hline Notes & $\begin{array}{l}\text { Exclusions: serious heart, liver, and kidney-related diseases; blood coagulation dysfunction; inability } \\
\text { to complete the MMSE test or bedside swallowing assessment; congenital disabilities; posterior circula- } \\
\text { tion infarcts; receiving thrombolytic; participated in other clinical trials within previous } 3 \text { months; preg- } \\
\text { nant or breastfeeding }\end{array}$ \\
\hline
\end{tabular}

\section{Risk of bias}


Chen 2016a (Continued)

$\begin{array}{ll}\begin{array}{l}\text { Random sequence genera- } \\ \text { tion (selection bias) }\end{array} & \text { Low risk }\end{array} \quad \begin{aligned} & \text { Computer-generated random numbers provided by independent research } \\ & \text { staff }\end{aligned}$
tion (selection bias) staff

\begin{tabular}{|c|c|c|}
\hline $\begin{array}{l}\text { Allocation concealment } \\
\text { (selection bias) }\end{array}$ & Low risk & $\begin{array}{l}\text { Random numbers placed into sequentially numbered, opaque, sealed en- } \\
\text { velopes }\end{array}$ \\
\hline
\end{tabular}

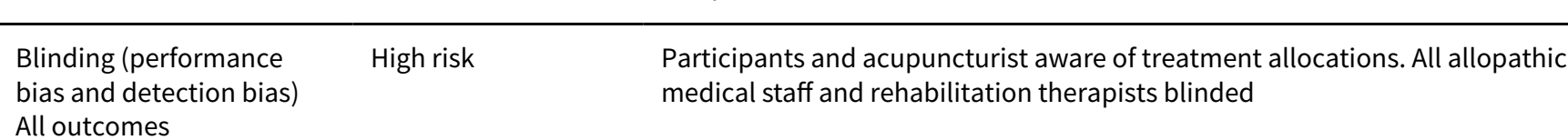

\begin{tabular}{|c|c|c|}
\hline $\begin{array}{l}\text { Blinding of participants } \\
\text { and personnel (perfor- } \\
\text { mance bias) } \\
\text { All outcomes }\end{array}$ & High risk & Participants and acupuncturist not blinded \\
\hline $\begin{array}{l}\text { Blinding of outcome as- } \\
\text { sessment (detection bias) } \\
\text { All outcomes }\end{array}$ & Low risk & Outcome assessors blinded \\
\hline $\begin{array}{l}\text { Incomplete outcome data } \\
\text { (attrition bias) } \\
\text { All outcomes }\end{array}$ & High risk & $\begin{array}{l}5 \text { participants lost to follow-up; } 4 \text { discontinued intervention. Not all partici- } \\
\text { pants given VFSS examination }\end{array}$ \\
\hline $\begin{array}{l}\text { Selective reporting (re- } \\
\text { porting bias) }\end{array}$ & Low risk & All outcomes reported \\
\hline Other bias & Low risk & None identified \\
\hline
\end{tabular}

\section{Du 2016i}

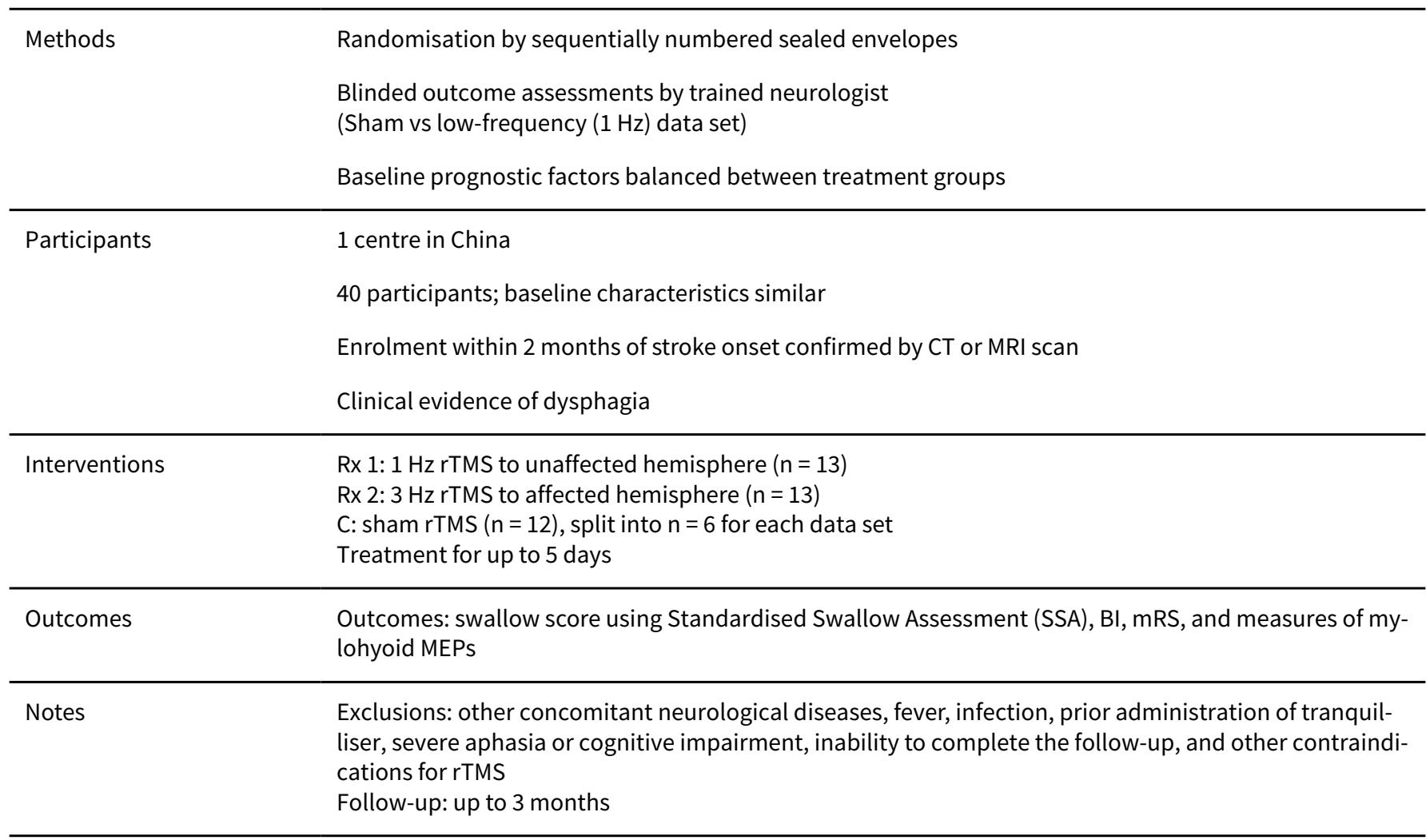


Du 2016i (Continued)

\section{Risk of bias}

\begin{tabular}{|c|c|c|}
\hline Bias & Authors' judgement & Support for judgement \\
\hline $\begin{array}{l}\text { Random sequence genera- } \\
\text { tion (selection bias) }\end{array}$ & Low risk & Randomisation by sequentially numbered sealed envelopes \\
\hline $\begin{array}{l}\text { Allocation concealment } \\
\text { (selection bias) }\end{array}$ & Low risk & Allocation concealed by sealed envelopes \\
\hline $\begin{array}{l}\text { Blinding (performance } \\
\text { bias and detection bias) } \\
\text { All outcomes }\end{array}$ & Low risk & Participant blinded; outcome assessor blinded \\
\hline $\begin{array}{l}\text { Blinding of participants } \\
\text { and personnel (perfor- } \\
\text { mance bias) } \\
\text { All outcomes }\end{array}$ & Low risk & Participant blinded \\
\hline $\begin{array}{l}\text { Blinding of outcome as- } \\
\text { sessment (detection bias) } \\
\text { All outcomes }\end{array}$ & Low risk & $\begin{array}{l}\text { Outcome assessor blinded - measures evaluated by a trained neurologist who } \\
\text { was blinded to participants' group allocation throughout }\end{array}$ \\
\hline $\begin{array}{l}\text { Incomplete outcome data } \\
\text { (attrition bias) } \\
\text { All outcomes }\end{array}$ & Low risk & 2 participants lost to follow-up \\
\hline $\begin{array}{l}\text { Selective reporting (re- } \\
\text { porting bias) }\end{array}$ & Low risk & $\begin{array}{l}\text { Only NIHSS not recorded at the end; all other measures reported on for all } 3 \\
\text { time points }\end{array}$ \\
\hline Other bias & Low risk & None identified \\
\hline
\end{tabular}

Du 2016ii

\begin{tabular}{|c|c|c|}
\hline Methods & \multicolumn{2}{|c|}{ (High-frequency vs sham data set) } \\
\hline Participants & \multicolumn{2}{|l|}{ As data set 1} \\
\hline Interventions & \multicolumn{2}{|c|}{$\begin{array}{l}\text { High = } 102 \text { (high intensity) } \\
\text { Sham = } 51 \text { (low intensity) }\end{array}$} \\
\hline Outcomes & \multicolumn{2}{|l|}{ As data set 1} \\
\hline Notes & \multicolumn{2}{|l|}{-} \\
\hline \multicolumn{3}{|l|}{ Risk of bias } \\
\hline Bias & Authors' judgement & Support for judgement \\
\hline $\begin{array}{l}\text { Random sequence genera- } \\
\text { tion (selection bias) }\end{array}$ & Low risk & Randomisation by sequentially numbered sealed envelopes \\
\hline $\begin{array}{l}\text { Allocation concealment } \\
\text { (selection bias) }\end{array}$ & Low risk & Allocation concealed by sealed envelopes \\
\hline
\end{tabular}




\section{Du 2016ii (Continued)}

Blinding (performance bias and detection bias)

All outcomes

\begin{tabular}{|c|c|c|}
\hline $\begin{array}{l}\text { Blinding of participants } \\
\text { and personnel (perfor- } \\
\text { mance bias) } \\
\text { All outcomes }\end{array}$ & Low risk & Participant blinded \\
\hline $\begin{array}{l}\text { Blinding of outcome as- } \\
\text { sessment (detection bias) } \\
\text { All outcomes }\end{array}$ & Low risk & $\begin{array}{l}\text { Outcome assessor blinded - measures evaluated by a trained neurologist who } \\
\text { was blinded to participants' group allocation throughout }\end{array}$ \\
\hline $\begin{array}{l}\text { Incomplete outcome data } \\
\text { (attrition bias) } \\
\text { All outcomes }\end{array}$ & Low risk & 2 participants lost to follow-up \\
\hline $\begin{array}{l}\text { Selective reporting (re- } \\
\text { porting bias) }\end{array}$ & Low risk & $\begin{array}{l}\text { Only NIHSS not recorded at the end; all other measures reported on for all } 3 \\
\text { time points }\end{array}$ \\
\hline Other bias & Low risk & None identified \\
\hline
\end{tabular}

Low risk Participant blinded; outcome assessor blinded

Feng 2012

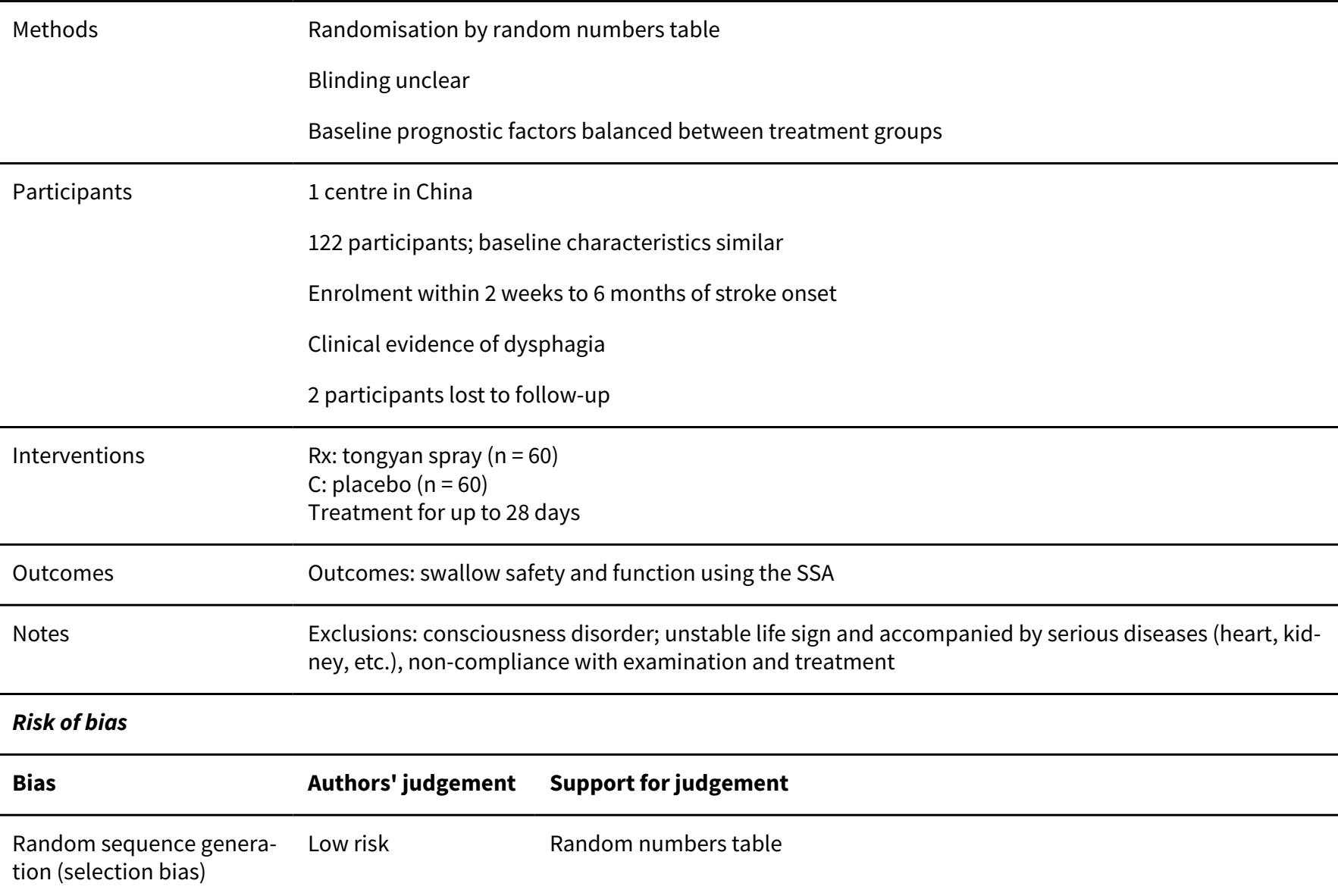


Feng 2012 (Continued)

\begin{tabular}{lll}
$\begin{array}{l}\text { Allocation concealment } \\
\text { (selection bias) }\end{array}$ & Low risk & Concealed via sealed envelopes \\
\hline $\begin{array}{l}\text { Blinding (performance } \\
\text { bias and detection bias) } \\
\text { All outcomes }\end{array}$ & Unclear risk & Blinding unclear \\
\hline
\end{tabular}

\begin{tabular}{|c|c|c|}
\hline $\begin{array}{l}\text { Blinding of participants } \\
\text { and personnel (perfor- } \\
\text { mance bias) } \\
\text { All outcomes }\end{array}$ & Unclear risk & Blinding unclear \\
\hline $\begin{array}{l}\text { Blinding of outcome as- } \\
\text { sessment (detection bias) } \\
\text { All outcomes }\end{array}$ & Unclear risk & Blinding unclear \\
\hline $\begin{array}{l}\text { Incomplete outcome data } \\
\text { (attrition bias) } \\
\text { All outcomes }\end{array}$ & Low risk & 2 participant dropouts ( 1 from each group) \\
\hline $\begin{array}{l}\text { Selective reporting (re- } \\
\text { porting bias) }\end{array}$ & Low risk & All outcomes listed reported \\
\hline Other bias & Low risk & None identified \\
\hline
\end{tabular}

Han 2004

\begin{tabular}{|c|c|c|}
\hline Methods & \multicolumn{2}{|c|}{ Randomisation by sealed opaque envelope. Assessors blinded } \\
\hline \multirow[t]{4}{*}{ Participants } & \multicolumn{2}{|c|}{ People with acute stroke, dysphagia, and dysarthria } \\
\hline & \multicolumn{2}{|l|}{1 centre in China } \\
\hline & \multicolumn{2}{|l|}{66 participants } \\
\hline & \multicolumn{2}{|c|}{$100 \%$ with stroke within 30 days of onset. Degrees of dysphagia not stated } \\
\hline \multirow[t]{2}{*}{ Interventions } & \multicolumn{2}{|c|}{ Rx: scalp and neck acupuncture with electroacupuncture with standard Western medical treatment } \\
\hline & \multicolumn{2}{|c|}{ C: standard Western medical treatment only } \\
\hline Outcomes & \multicolumn{2}{|c|}{ Dysphagia at end of trial after 3 treatment sessions } \\
\hline Notes & \multicolumn{2}{|c|}{ Exclusions: reduced consciousness, poor compliance, infections at acupoints } \\
\hline \multicolumn{3}{|l|}{ Risk of bias } \\
\hline Bias & Authors' judgement & Support for judgement \\
\hline $\begin{array}{l}\text { Random sequence genera- } \\
\text { tion (selection bias) }\end{array}$ & Low risk & Randomisation by sealed opaque envelopes \\
\hline $\begin{array}{l}\text { Allocation concealment } \\
\text { (selection bias) }\end{array}$ & Low risk & Allocations concealed by opaque envelopes \\
\hline $\begin{array}{l}\text { Blinding (performance } \\
\text { bias and detection bias) }\end{array}$ & Unclear risk & Unclear \\
\hline
\end{tabular}


Han 2004 (Continued)

All outcomes

Blinding of participants Unclear risk Unclear
and personnel (perfor-
mance bias)
All outcomes

Blinding of outcome as- Low risk Assessors blinded
sessment (detection bias)

All outcomes

\begin{tabular}{l}
\hline Incomplete outcome data Low risk None lost to follow-up \\
(attrition bias) \\
All outcomes
\end{tabular}

\begin{tabular}{lll}
\hline $\begin{array}{l}\text { Selective reporting (re- } \\
\text { porting bias) }\end{array}$ & Unclear risk & Unclear \\
\hline Other bias & Low risk & None identified \\
\hline
\end{tabular}

Heo 2015

Methods Participants were randomly allocated for radiographic inspection and treatment with or without kinesiotaping by drawing lots

Blinding unknown

\begin{tabular}{ll}
\hline Participants & 1 centre in Republic of Korea \\
& 44 participants \\
$100 \%$ with dysphagia and stroke within 3 months of diagnosis & Baseline characteristics similar \\
\hline Interventions & Rx: kinesiotaping \\
& C: no kinesiotaping \\
\hline Outcomes & Kinematic analysis of movement of the hyoid bone (movements measured in both horizontal and verti- \\
cal sections) & Angular variation of the epiglottis using human anatomy-based co-ordinates \\
& Swallow score: FDS \\
\hline Notes & Exclusions: none
\end{tabular}

\section{Risk of bias}

Bias Authors' judgement Support for judgement

Random sequence genera- Low risk Participants randomly allocated by drawing lots
tion (selection bias)

\begin{tabular}{ll}
\hline $\begin{array}{l}\text { Allocation concealment } \\
\text { (selection bias) }\end{array}$ & Unclear risk
\end{tabular}


Heo 2015 (Continued)
Blinding (performance
Unclear risk
Blinding unclear
bias and detection bias)

All outcomes

Blinding of participants Unclear risk Unclear
and personnel (perfor-
mance bias)
All outcomes

\begin{tabular}{|c|c|c|}
\hline $\begin{array}{l}\text { Blinding of outcome as- } \\
\text { sessment (detection bias) } \\
\text { All outcomes }\end{array}$ & Unclear risk & Unclear \\
\hline $\begin{array}{l}\text { Incomplete outcome data } \\
\text { (attrition bias) } \\
\text { All outcomes }\end{array}$ & Unclear risk & Unclear \\
\hline $\begin{array}{l}\text { Selective reporting (re- } \\
\text { porting bias) }\end{array}$ & Low risk & All outcomes reported \\
\hline Other bias & Low risk & None identified \\
\hline
\end{tabular}

Huang 2010

\begin{tabular}{ll}
\hline Methods & Method of randomisation unknown \\
& $\begin{array}{l}\text { Blinding unknown } \\
\text { Only data for groups } 2 \text { and } 3 \text { included }\end{array}$ \\
\hline Participants & $\begin{array}{l}1 \text { centre in China } \\
\text { 97 participants with post-stroke dysphagia }\end{array}$ \\
\hline Interventions & Group 1: electrical stimulation $(\mathrm{n}=35)$ \\
& Group 2: rehabilitation training $(\mathrm{n}=30)$ \\
& Group 3: acupuncture $(\mathrm{n}=32)$ \\
\hline Outcomes & Swallowing function \\
\hline Notes & -
\end{tabular}

\section{Risk of bias}

\begin{tabular}{lll}
\hline Bias & Authors' judgement & Support for judgement \\
\hline $\begin{array}{l}\text { Random sequence genera- } \\
\text { tion (selection bias) }\end{array}$ & Unclear risk & Method of randomisation unknown \\
\hline $\begin{array}{l}\text { Allocation concealment } \\
\text { (selection bias) }\end{array}$ & Unclear risk & Unclear \\
\hline $\begin{array}{l}\text { Blinding (performance } \\
\text { bias and detection bias) }\end{array}$ & Unclear risk & Blinding unknown \\
\end{tabular}


Huang 2010 (Continued)

All outcomes

Blinding of participants Unclear risk Unclear
and personnel (perfor-
mance bias)
All outcomes

\begin{tabular}{lll}
\hline Blinding of outcome as- & Unclear risk & Unclear \\
sessment (detection bias) & \\
All outcomes &
\end{tabular}

\begin{tabular}{lll}
\hline $\begin{array}{l}\text { Incomplete outcome data } \\
\text { (attrition bias) } \\
\text { All outcomes }\end{array}$ & Unclear risk & Unclear \\
\hline $\begin{array}{l}\text { Selective reporting (re- } \\
\text { porting bias) }\end{array}$ & Unclear risk & Unclear \\
\hline Other bias & Unclear risk & Translated from Chinese language \\
\hline
\end{tabular}

Methods Dose comparison protocol (only data from the group that were stimulated once a day over 3 days were
included)

Computerised randomisation by minimisation

Blinded outcome measures

Balancing of prognostic baseline factors between treatment groups unclear

\begin{tabular}{ll}
\hline Participants & 1 centre in UK \\
& 10 participants with acute anterior circulation cerebral infarct (<3 weeks) \\
& Mean age 73 years \\
\hline Interventions & Rx: bedside pharyngeal electrical stimulation \\
& C: sham stimulation \\
Duration: once daily for 3 consecutive days
\end{tabular}

\section{Risk of bias}

\begin{tabular}{lll}
\hline Bias & Authors' judgement & Support for judgement \\
\hline $\begin{array}{l}\text { Random sequence genera- } \\
\text { tion (selection bias) }\end{array}$ & Low risk & Computerised randomisation by minimisation \\
\hline $\begin{array}{l}\text { Allocation concealment } \\
\text { (selection bias) }\end{array}$ & Unclear risk & Not reported \\
\hline
\end{tabular}


Jayasekeran 2010a (Continued)
Blinding (performance
Unclear risk
Unclear
bias and detection bias)
All outcomes

Blinding of participants Unclear risk Unclear
and personnel (perfor-
mance bias)
All outcomes

\begin{tabular}{|c|c|c|}
\hline $\begin{array}{l}\text { Blinding of outcome as- } \\
\text { sessment (detection bias) } \\
\text { All outcomes }\end{array}$ & Low risk & Blinded outcome measures \\
\hline $\begin{array}{l}\text { Incomplete outcome data } \\
\text { (attrition bias) } \\
\text { All outcomes }\end{array}$ & Low risk & None lost to follow-up \\
\hline $\begin{array}{l}\text { Selective reporting (re- } \\
\text { porting bias) }\end{array}$ & Low risk & All outcomes reported \\
\hline Other bias & Low risk & None identified \\
\hline
\end{tabular}

Jayasekeran 2010b

\begin{tabular}{|c|c|}
\hline Methods & $\begin{array}{l}\text { Parallel-group design protocol } \\
\text { Computerised randomisation by minimisation } \\
\text { Blinded outcome measures } \\
\text { Prognostic baseline factors between treatment groups similar }\end{array}$ \\
\hline Participants & $\begin{array}{l}2 \text { centres in UK } \\
28 \text { participants with acute anterior circulation cerebral infarct or haemorrhage (<3 weeks) } \\
\text { Mean age } 75 \text { years }\end{array}$ \\
\hline Interventions & $\begin{array}{l}\text { Rx: bedside pharyngeal electrical stimulation } \\
\text { C: sham stimulation } \\
\text { Duration: once daily for } 3 \text { consecutive days }\end{array}$ \\
\hline Outcomes & Airway aspiration at 2 weeks post intervention \\
\hline Notes & $\begin{array}{l}\text { Exclusion: dementia, pacemaker or implantable cardiac defibrillator, severe receptive aphasia, un- } \\
\text { stable cardiopulmonary status, distorted oropharyngeal anatomy (e.g. pharyngeal pouch), brainstem } \\
\text { stroke, dysphagia resulting from conditions other than hemispheric stroke }\end{array}$ \\
\hline
\end{tabular}

\section{Risk of bias}

\section{Bias}

\section{Authors' judgement Support for judgement}

Computerised randomisation by minimisation 
Jayasekeran 2010b (Continued)

\begin{tabular}{lll}
$\begin{array}{l}\text { Allocation concealment } \\
\text { (selection bias) }\end{array}$ & Unclear risk & Not reported \\
\hline $\begin{array}{l}\text { Blinding (performance } \\
\text { bias and detection bias) }\end{array}$ & Unclear risk & Unclear \\
All outcomes & &
\end{tabular}

Blinding of participants Unclear risk
and personnel (perfor-
mance bias)
All outcomes

\begin{tabular}{|c|c|c|}
\hline $\begin{array}{l}\text { Blinding of outcome as- } \\
\text { sessment (detection bias) } \\
\text { All outcomes }\end{array}$ & Low risk & Blinded outcome measures \\
\hline $\begin{array}{l}\text { Incomplete outcome data } \\
\text { (attrition bias) } \\
\text { All outcomes }\end{array}$ & High risk & 3 participants lost to follow-up \\
\hline $\begin{array}{l}\text { Selective reporting (re- } \\
\text { porting bias) }\end{array}$ & Low risk & All outcomes reported \\
\hline Other bias & Low risk & None identified \\
\hline
\end{tabular}

Jia 2006a

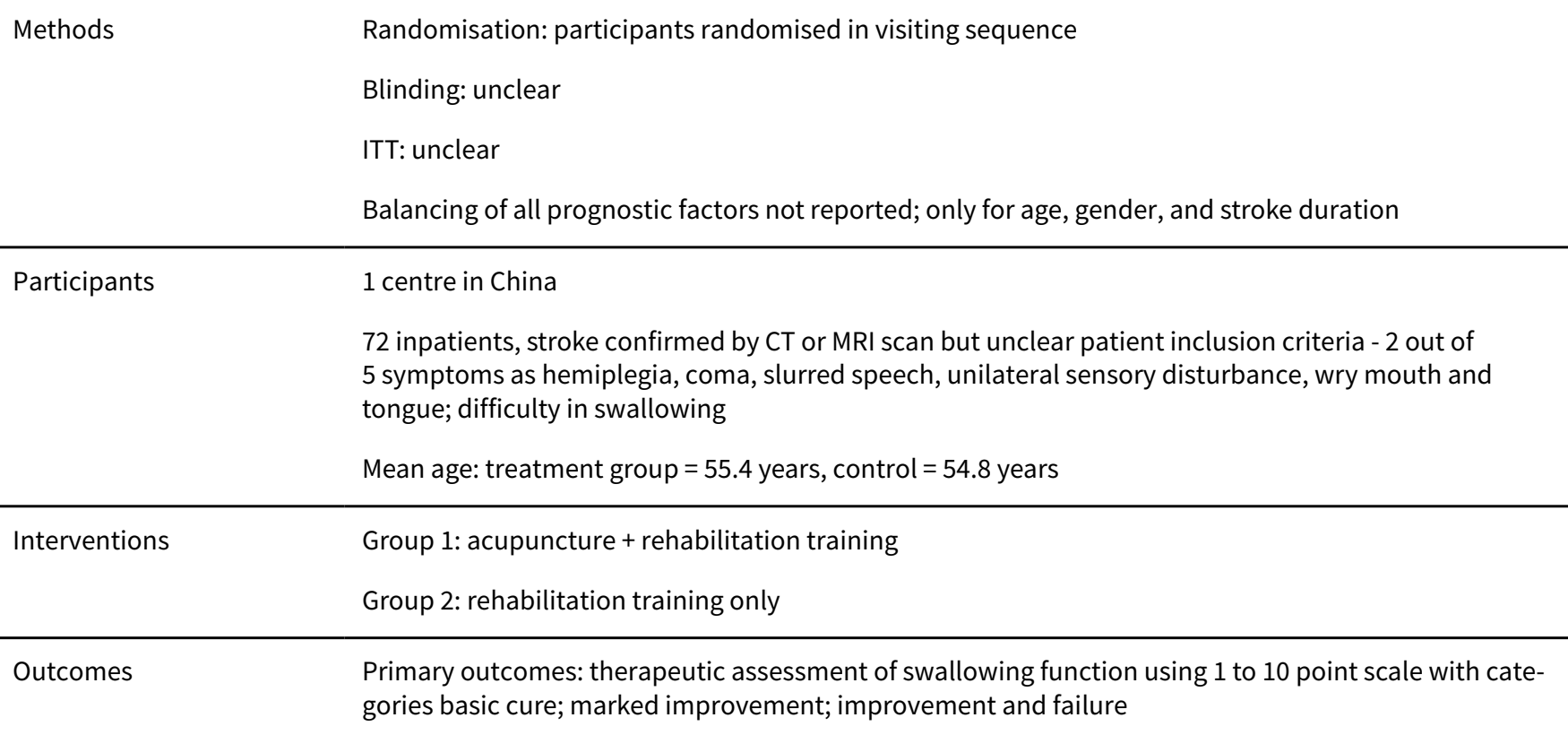

Notes Not having above symptoms; cannot co-operate to do chemical examination and treatment; severe primary disease in the liver, kidneys, hematopoietic system, and endocrine system

\section{Risk of bias}


Jia 2006a (Continued)

Random sequence genera- High risk $\quad$ Participants randomised in visiting sequence
tion (selection bias)

\begin{tabular}{|c|c|c|}
\hline $\begin{array}{l}\text { Allocation concealment } \\
\text { (selection bias) }\end{array}$ & High risk & Allocation not concealed \\
\hline $\begin{array}{l}\text { Blinding (performance } \\
\text { bias and detection bias) } \\
\text { All outcomes }\end{array}$ & Unclear risk & Blinding unclear \\
\hline $\begin{array}{l}\text { Blinding of participants } \\
\text { and personnel (perfor- } \\
\text { mance bias) } \\
\text { All outcomes }\end{array}$ & Unclear risk & Unclear \\
\hline $\begin{array}{l}\text { Blinding of outcome as- } \\
\text { sessment (detection bias) } \\
\text { All outcomes }\end{array}$ & Unclear risk & Unclear \\
\hline $\begin{array}{l}\text { Incomplete outcome data } \\
\text { (attrition bias) } \\
\text { All outcomes }\end{array}$ & Unclear risk & Unclear \\
\hline $\begin{array}{l}\text { Selective reporting (re- } \\
\text { porting bias) }\end{array}$ & Unclear risk & $\begin{array}{l}\text { Only } 1 \text { outcome chosen and reported - improvement in swallowing at end of } \\
\text { trial }\end{array}$ \\
\hline Other bias & Unclear risk & Unclear \\
\hline
\end{tabular}

\section{Kang 2012}

\begin{tabular}{ll}
\hline Methods & Method of randomisation unclear \\
& Baseline prognostic factors balanced between treatment groups \\
\hline Participants & 25 participants; baseline characteristics similar \\
& Enrolment within 6 weeks of stroke onset \\
& Clinical and videofluoroscopic evidence of dysphagia \\
\hline Interventions & $\begin{array}{l}\text { R: : thermal-tactile stimulation only } \\
\text { Treatment for up to } 2 \text { months }\end{array}$ \\
\hline Outcomes & $\begin{array}{l}\text { Videofluoroscopy, Functional Oral Intake Scale, transition from tube to oral feeding, incidence of aspi- } \\
\text { ration pneumonia }\end{array}$ \\
\hline Notes & $\begin{array}{l}\text { Exclusions: previous history of other diseases, which may have caused dysphagia; severe cognitive dis- } \\
\text { order, such as dementia; inability to carry out videofluoroscopy due to incapability of sitting posture; } \\
\text { inability to follow study instructions }\end{array}$
\end{tabular}

\section{Risk of bias}

Bias Authors' judgement Support for judgement


Kang 2012 (Continued)

\begin{tabular}{lll}
$\begin{array}{l}\text { Random sequence genera- } \\
\text { tion (selection bias) }\end{array}$ & Unclear risk & Randomisation unclear \\
\hline $\begin{array}{l}\text { Allocation concealment } \\
\text { (selection bias) }\end{array}$ & Unclear risk & Blinding unclear
\end{tabular}

Blinding (performance
bias and detection bias) Unclear risk \begin{tabular}{l} 
All outcomes \\
\hline
\end{tabular}

\begin{tabular}{lll}
\hline $\begin{array}{l}\text { Blinding of participants } \\
\text { and personnel (perfor- } \\
\text { mance bias) }\end{array}$ & Unclear risk & \\
$\begin{array}{l}\text { All outcomes } \\
\text { Blinding of outcome as- } \\
\text { sessment (detection bias) } \\
\text { All outcomes }\end{array}$ & Unclear risk & Unclear \\
\hline $\begin{array}{l}\text { Incomplete outcome data } \\
\text { (attrition bias) }\end{array}$ & Low risk & \\
$\begin{array}{l}\text { All outcomes } \\
\text { Selective reporting (re- }\end{array}$ & Low risk & None reported \\
porting bias) & Unclear risk & Unclear \\
\hline $\begin{array}{l}\text { Other bias } \\
\end{array}$
\end{tabular}

\section{Khedr 2009}

\begin{tabular}{|c|c|}
\hline \multirow[t]{4}{*}{ Methods } & $\begin{array}{l}\text { Method of randomisation unclear: participants were assigned randomly to receive real or sham rTMS } \\
\text { using closed envelopes }\end{array}$ \\
\hline & Blinded outcome assessment \\
\hline & Allocation sequence concealed from participants \\
\hline & Baseline prognostic factors balanced between treatment groups \\
\hline \multirow[t]{3}{*}{ Participants } & 1 centre in Egypt \\
\hline & 26 participants between 5 th and 10th days post stroke (monohemispheric) \\
\hline & Mean age 56 years \\
\hline \multirow[t]{2}{*}{ Interventions } & Rx: repetitive transcranial magnetic stimulation of the affected motor cortex $(n=14)$ \\
\hline & C: sham stimulation $(\mathrm{n}=12)$ \\
\hline \multirow[t]{2}{*}{ Outcomes } & Primary outcome: score on the dysphagia rating scale \\
\hline & $\begin{array}{l}\text { Secondary outcomes: motor power of hand grip, BI, measures of oesophageal motor evoked potentials } \\
\text { from both hemispheres before and } 1 \text { month after sessions }\end{array}$ \\
\hline Notes & $\begin{array}{l}\text { Exclusion: head injury or neurological disease other than stroke, unstable cardiac dysrhythmia, fever, } \\
\text { infection, hyperglycaemia, prior administration of tranquilliser }\end{array}$ \\
\hline
\end{tabular}


Khedr 2009 (Continued)

Risk of bias

\begin{tabular}{|c|c|c|}
\hline Bias & Authors' judgement & Support for judgement \\
\hline $\begin{array}{l}\text { Random sequence genera- } \\
\text { tion (selection bias) }\end{array}$ & Unclear risk & Method of randomisation unclear \\
\hline $\begin{array}{l}\text { Allocation concealment } \\
\text { (selection bias) }\end{array}$ & Low risk & Allocation sequence concealed from participants \\
\hline $\begin{array}{l}\text { Blinding (performance } \\
\text { bias and detection bias) } \\
\text { All outcomes }\end{array}$ & Low risk & Participants and outcome assessors not aware of allocation \\
\hline $\begin{array}{l}\text { Blinding of participants } \\
\text { and personnel (perfor- } \\
\text { mance bias) } \\
\text { All outcomes }\end{array}$ & Low risk & $\begin{array}{l}\text { Participants informed of which group they had been allocated to at the end of } \\
\text { the last assessment }\end{array}$ \\
\hline $\begin{array}{l}\text { Blinding of outcome as- } \\
\text { sessment (detection bias) } \\
\text { All outcomes }\end{array}$ & Low risk & Blinded outcome assessment \\
\hline $\begin{array}{l}\text { Incomplete outcome data } \\
\text { (attrition bias) } \\
\text { All outcomes }\end{array}$ & Low risk & $\begin{array}{l}\text { All participants apart from } 1 \text { in the sham treatment group who died completed } \\
\text { the trial and follow-up periods }\end{array}$ \\
\hline $\begin{array}{l}\text { Selective reporting (re- } \\
\text { porting bias) }\end{array}$ & Low risk & All outcomes reported \\
\hline Other bias & Low risk & None identified \\
\hline
\end{tabular}

Khedr 2010

\begin{tabular}{|c|c|}
\hline \multirow[t]{3}{*}{ Methods } & $\begin{array}{l}\text { Method of randomisation unclear: participants from both the lateral medullary infarction (LMI) group } \\
\text { and the other brainstem infarction group were each randomly classified into } 2 \text { groups - to receive real } \\
\text { or sham repetitive transcranial magnetic stimulation }\end{array}$ \\
\hline & Blinded primary outcome assessment \\
\hline & Baseline prognostic factors balanced between treatment groups \\
\hline \multirow[t]{3}{*}{ Participants } & 1 centre in Egypt \\
\hline & $\begin{array}{l}\text { Total of } 22 \text { participants with hemispheric stroke split into having lateral medullary infarction or other } \\
\text { brainstem infarction }\end{array}$ \\
\hline & Mean age 58 years \\
\hline \multirow[t]{2}{*}{ Interventions } & Rx: repetitive transcranial magnetic stimulation of the affected motor cortex $(n=11)$ \\
\hline & C: sham stimulation $(n=11)$ \\
\hline \multirow[t]{2}{*}{ Outcomes } & Primary outcome: score on the dysphagia rating scale \\
\hline & Secondary outcomes: motor power of hand grip, BI, NIHSS \\
\hline
\end{tabular}


Khedr 2010 (Continued)

Notes

Exclusion: head injury or neurological disease other than stroke, unstable cardiac dysrhythmia, fever, infection, hyperglycaemia, epilepsy, prior administration of tranquilliser

\section{Risk of bias}

\begin{tabular}{|c|c|c|}
\hline Bias & Authors' judgement & Support for judgement \\
\hline $\begin{array}{l}\text { Random sequence genera- } \\
\text { tion (selection bias) }\end{array}$ & Unclear risk & Method of randomisation unclear \\
\hline $\begin{array}{l}\text { Allocation concealment } \\
\text { (selection bias) }\end{array}$ & Unclear risk & Unclear \\
\hline $\begin{array}{l}\text { Blinding (performance } \\
\text { bias and detection bias) } \\
\text { All outcomes }\end{array}$ & Unclear risk & Unclear \\
\hline $\begin{array}{l}\text { Blinding of participants } \\
\text { and personnel (perfor- } \\
\text { mance bias) } \\
\text { All outcomes }\end{array}$ & Unclear risk & Unclear \\
\hline $\begin{array}{l}\text { Blinding of outcome as- } \\
\text { sessment (detection bias) } \\
\text { All outcomes }\end{array}$ & Low risk & Blinded outcome assessment \\
\hline $\begin{array}{l}\text { Incomplete outcome data } \\
\text { (attrition bias) } \\
\text { All outcomes }\end{array}$ & Low risk & $\begin{array}{l}\text { All participants apart from } 2 \text { in the sham treatment group who died completed } \\
\text { the trial and follow-up periods }\end{array}$ \\
\hline $\begin{array}{l}\text { Selective reporting (re- } \\
\text { porting bias) }\end{array}$ & Low risk & All outcomes reported \\
\hline Other bias & Low risk & None identified \\
\hline
\end{tabular}

\section{Kim 2012i}

\begin{tabular}{ll} 
Methods & Method of randomisation unclear \\
& Blinding unclear \\
& (High frequency data set vs control) \\
\hline Participants & 1 centre in Korea \\
& 30 participants with acute brain injury; baseline characteristics similar \\
& Clinical and videofluoroscopic evidence of dysphagia \\
& Rx 1: high-frequency $(5$ Hz) rTMS ( $n=10)$ \\
& Rx 2: low-frequency $(1 \mathrm{~Hz})$ rTMS $(n=10)$ \\
& (Using high frequency data set) \\
C: sham stimulation. $(n=10) ;$ control $=5$ \\
Treatment for 2 weeks
\end{tabular}


Kim 2012i (Continued)

Outcomes Functional Dysphagia Scale and Penetration Aspiration Scale

Notes Exclusions: prior diagnosis of another neurological disease, unstable medical condition, severe cogni-
tive impairment, severe aphasia, history of seizure

\title{
Risk of bias
}

\begin{tabular}{lll}
\hline Bias & Authors' judgement & Support for judgement \\
\hline $\begin{array}{l}\text { Random sequence genera- } \\
\text { tion (selection bias) }\end{array}$ & Unclear risk & Method of randomisation unclear \\
\hline $\begin{array}{l}\text { Allocation concealment } \\
\text { (selection bias) }\end{array}$ & Unclear risk & Unclear \\
\hline
\end{tabular}

\begin{tabular}{ll}
\hline Blinding (performance & Unclear risk \\
bias and detection bias) & \\
All outcomes & \\
\hline
\end{tabular}

Blinding of participants Unclear risk Unclear
and personnel (perfor-
mance bias)
All outcomes

\begin{tabular}{|c|c|c|}
\hline $\begin{array}{l}\text { Blinding of outcome as- } \\
\text { sessment (detection bias) } \\
\text { All outcomes }\end{array}$ & Unclear risk & Unclear \\
\hline $\begin{array}{l}\text { Incomplete outcome data } \\
\text { (attrition bias) } \\
\text { All outcomes }\end{array}$ & Low risk & None lost to follow-up \\
\hline $\begin{array}{l}\text { Selective reporting (re- } \\
\text { porting bias) }\end{array}$ & Low risk & All outcomes reported \\
\hline Other bias & Low risk & None identified \\
\hline
\end{tabular}

Kim 2012ii

\begin{tabular}{ll}
\hline Methods & (Low-frequency data set vs control) \\
\hline Participants & As data set 1 \\
\hline Interventions & $\begin{array}{l}\text { Low-frequency rTMS }=10 \\
\text { Control (sham stimulation) }=5\end{array}$ \\
\hline Outcomes & As data set 1 \\
\hline Notes & \\
\hline
\end{tabular}

\section{Risk of bias}

\section{Bias}

\author{
Authors' judgement Support for judgement
}


Kim 2012ii (Continued)

Random sequence genera- Unclear risk $\quad$ Method of randomisation unclear
tion (selection bias)
tion (selection bias)

\begin{tabular}{ll}
\hline $\begin{array}{l}\text { Allocation concealment Unclear risk } \\
\text { (selection bias) }\end{array}$ & Unclear
\end{tabular}

\begin{tabular}{|c|c|c|}
\hline $\begin{array}{l}\text { Blinding (performance } \\
\text { bias and detection bias) } \\
\text { All outcomes }\end{array}$ & Unclear risk & Unclear \\
\hline $\begin{array}{l}\text { Blinding of participants } \\
\text { and personnel (perfor- } \\
\text { mance bias) } \\
\text { All outcomes }\end{array}$ & Unclear risk & Unclear \\
\hline $\begin{array}{l}\text { Blinding of outcome as- } \\
\text { sessment (detection bias) } \\
\text { All outcomes }\end{array}$ & Unclear risk & Unclear \\
\hline $\begin{array}{l}\text { Incomplete outcome data } \\
\text { (attrition bias) } \\
\text { All outcomes }\end{array}$ & Low risk & None lost to follow-up \\
\hline $\begin{array}{l}\text { Selective reporting (re- } \\
\text { porting bias) }\end{array}$ & Low risk & All outcomes reported \\
\hline Other bias & Low risk & None identified \\
\hline
\end{tabular}

Kumar 2011

\begin{tabular}{ll}
\hline Methods & Randomisation via simple randomisation \\
& Double-blind \\
& Analysis by ITT unclear \\
& Balancing of prognostic baseline factors between treatment groups unclear \\
\hline Participants & 1 centre in USA \\
& 14 participants with subacute (24 to 168 hours) unilateral hemispheric infarction \\
& Mean age 75 years \\
\hline Interventions & Rx: anodal transcranial direct current stimulation \\
C: sham stimulation \\
For 5 consecutive days \\
\hline Outcomes & Swallowing impairment using dysphagia outcome and severity scale \\
\hline Notes & $\begin{array}{l}\text { Exclusions: difficulty following instructions because of obtundation or cognitive impairment, pre-exist- } \\
\text { ing swallowing problems; other contraindications to transcranial direct current stimulation }\end{array}$ \\
\hline
\end{tabular}


Kumar 2011 (Continued)

Bias Authors' judgement Support for judgement

\begin{tabular}{|c|c|c|}
\hline $\begin{array}{l}\text { Random sequence genera- } \\
\text { tion (selection bias) }\end{array}$ & Unclear risk & Randomisation via simple randomisation \\
\hline $\begin{array}{l}\text { Allocation concealment } \\
\text { (selection bias) }\end{array}$ & Unclear risk & Unclear \\
\hline $\begin{array}{l}\text { Blinding (performance } \\
\text { bias and detection bias) } \\
\text { All outcomes }\end{array}$ & Low risk & Double-blind \\
\hline $\begin{array}{l}\text { Blinding of participants } \\
\text { and personnel (perfor- } \\
\text { mance bias) } \\
\text { All outcomes }\end{array}$ & Low risk & Double-blind \\
\hline
\end{tabular}

\begin{tabular}{|c|c|c|}
\hline $\begin{array}{l}\text { Blinding of outcome as- } \\
\text { sessment (detection bias) } \\
\text { All outcomes }\end{array}$ & Unclear risk & Unclear \\
\hline $\begin{array}{l}\text { Incomplete outcome data } \\
\text { (attrition bias) } \\
\text { All outcomes }\end{array}$ & Unclear risk & Unclear \\
\hline $\begin{array}{l}\text { Selective reporting (re- } \\
\text { porting bias) }\end{array}$ & Low risk & All outcomes reported and explained \\
\hline Other bias & Low risk & None identified \\
\hline
\end{tabular}

Lee 2014

Randomisation via computer-generated block randomisation
Blinding unclear
Analysis by ITT unclear
Prognostic baseline factors between treatment groups similar

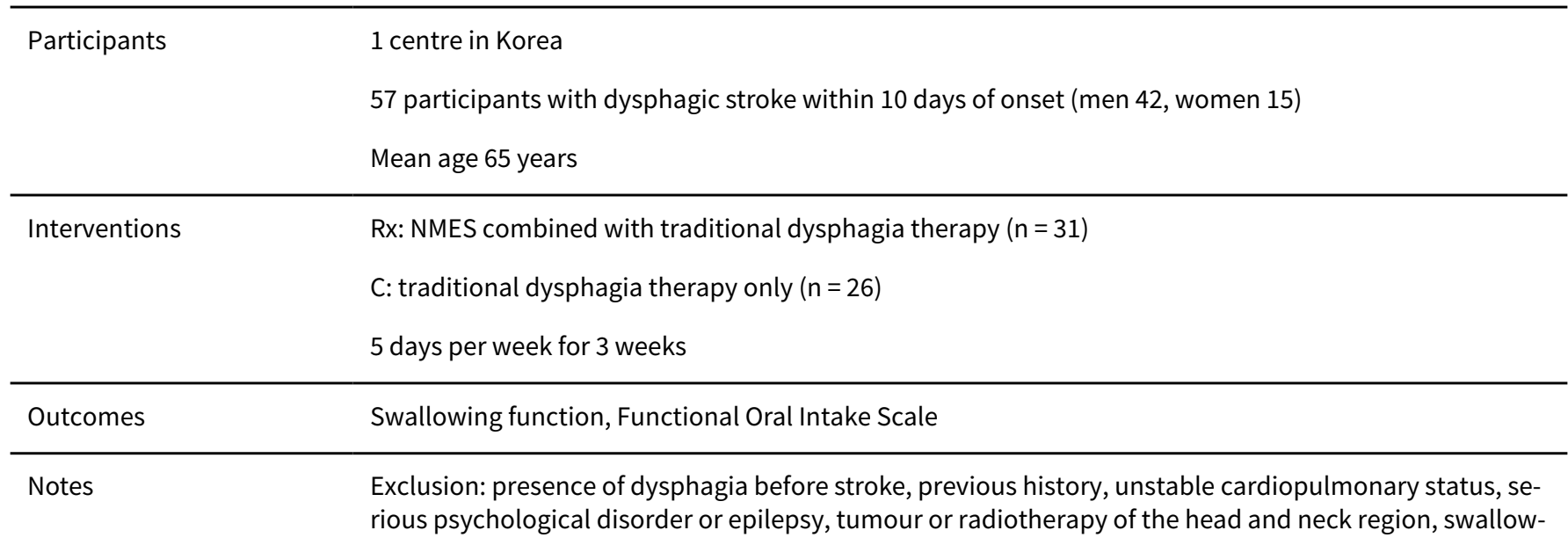


Lee 2014 (Continued)

ing therapy before participation in the present study, unstable medical conditions that may interfere with VFSS

\section{Risk of bias}

\begin{tabular}{|c|c|c|}
\hline Bias & Authors' judgement & Support for judgement \\
\hline $\begin{array}{l}\text { Random sequence genera- } \\
\text { tion (selection bias) }\end{array}$ & Low risk & Computer-generated block randomisation \\
\hline $\begin{array}{l}\text { Allocation concealment } \\
\text { (selection bias) }\end{array}$ & Unclear risk & Not reported \\
\hline $\begin{array}{l}\text { Blinding (performance } \\
\text { bias and detection bias) } \\
\text { All outcomes }\end{array}$ & Unclear risk & Unclear \\
\hline $\begin{array}{l}\text { Blinding of participants } \\
\text { and personnel (perfor- } \\
\text { mance bias) } \\
\text { All outcomes }\end{array}$ & Unclear risk & Unclear \\
\hline $\begin{array}{l}\text { Blinding of outcome as- } \\
\text { sessment (detection bias) } \\
\text { All outcomes }\end{array}$ & Unclear risk & Unclear \\
\hline $\begin{array}{l}\text { Incomplete outcome data } \\
\text { (attrition bias) } \\
\text { All outcomes }\end{array}$ & Low risk & All participants appeared to have been followed up at 12 weeks \\
\hline $\begin{array}{l}\text { Selective reporting (re- } \\
\text { porting bias) }\end{array}$ & Low risk & All outcomes reported \\
\hline Other bias & Low risk & None identified \\
\hline
\end{tabular}

\section{Lee 2015}

\begin{tabular}{ll}
\hline Methods & Randomisation by computer-generated random sequence \\
& Outcome assessors blinded \\
\hline Participants & Multi-centre trial in Hong Kong \\
& 93 participants with cerebrovascular disease; onset unclear although study states recent hospitalisa- \\
tion in the previous 3 months & Baseline characteristics and prognostic factors similar \\
\hline Interventions & Rx: lisinopril 2.5 mg once daily at bedtime \\
C: placebo
\end{tabular}

\begin{tabular}{ll}
\hline Outcomes & Incidence of pneumonia, mortality, and Royal Brisbane Hospital Outcome Measure Scale score \\
\hline Notes & $\begin{array}{l}\text { Exclusion: life expectancy }<6 \text { months, baseline systolic blood pressure less than } 100 \mathrm{~mm} \mathrm{Hg}, \mathrm{known} \text { in- } \\
\text { tolerance to ACE inhibitors, current use of ACE inhibitor or angiotensin receptor blockers, symptomatic }\end{array}$
\end{tabular}


Lee 2015 (Continued)

chronic lung disease or cardiac failure, frequent withdrawal of enteral tube by patients, serum creatinine $>150 \mathrm{mmol} / \mathrm{L}$, serum potassium $>5.1 \mathrm{mmol} / \mathrm{L}$

\section{Risk of bias}

\begin{tabular}{|c|c|c|}
\hline Bias & Authors' judgement & Support for judgement \\
\hline $\begin{array}{l}\text { Random sequence genera- } \\
\text { tion (selection bias) }\end{array}$ & Low risk & Computer-generated random sequence \\
\hline $\begin{array}{l}\text { Allocation concealment } \\
\text { (selection bias) }\end{array}$ & Low risk & $\begin{array}{l}\text { Allocations concealed by coding files kept confidential to all parties involved } \\
\text { until the end of the trial }\end{array}$ \\
\hline $\begin{array}{l}\text { Blinding (performance } \\
\text { bias and detection bias) } \\
\text { All outcomes }\end{array}$ & Low risk & All parties involved not aware of allocation \\
\hline $\begin{array}{l}\text { Blinding of participants } \\
\text { and personnel (perfor- } \\
\text { mance bias) } \\
\text { All outcomes }\end{array}$ & Low risk & All parties involved not aware of allocation \\
\hline $\begin{array}{l}\text { Blinding of outcome as- } \\
\text { sessment (detection bias) } \\
\text { All outcomes }\end{array}$ & Low risk & Outcome assessor blinded \\
\hline $\begin{array}{l}\text { Incomplete outcome data } \\
\text { (attrition bias) } \\
\text { All outcomes }\end{array}$ & High risk & 22 participants did not complete trial \\
\hline $\begin{array}{l}\text { Selective reporting (re- } \\
\text { porting bias) }\end{array}$ & Low risk & All outcomes reported \\
\hline Other bias & Low risk & None identified \\
\hline
\end{tabular}

\section{Li 2014}

\begin{tabular}{ll}
\hline Methods & Randomisation via minimisation software \\
& Single-blind - assessors blinded \\
& No significant differences in baseline comparability tests in all groups of participants \\
\hline
\end{tabular}

Participants

Recruitment through newspaper advertisements and flyers in China

118 participants with dysphagia and hemispheric stroke

Rx 1: neuromuscular electrical stimulation (VitalStim)
Rx 2: combined NMES and traditional swallowing therapy
C: traditional swallowing therapy
(Data from Rx 2 vs control used in this review)


Li 2014 (Continued)

Notes

Exclusion: progressive stroke, other neurological disease, neoplastic disease, previous surgery to swal-

lowing apparatus, nasogastric tube

\section{Risk of bias}

\begin{tabular}{|c|c|c|}
\hline Bias & Authors' judgement & Support for judgement \\
\hline $\begin{array}{l}\text { Random sequence genera- } \\
\text { tion (selection bias) }\end{array}$ & Low risk & Computer randomisation via minimisation software \\
\hline $\begin{array}{l}\text { Allocation concealment } \\
\text { (selection bias) }\end{array}$ & Low risk & Allocation concealed by sealed envelope \\
\hline $\begin{array}{l}\text { Blinding (performance } \\
\text { bias and detection bias) } \\
\text { All outcomes }\end{array}$ & Low risk & Outcome assessor blinded \\
\hline $\begin{array}{l}\text { Blinding of participants } \\
\text { and personnel (perfor- } \\
\text { mance bias) } \\
\text { All outcomes }\end{array}$ & High risk & Participants and technicians not blinded \\
\hline $\begin{array}{l}\text { Blinding of outcome as- } \\
\text { sessment (detection bias) } \\
\text { All outcomes }\end{array}$ & Low risk & As above \\
\hline $\begin{array}{l}\text { Incomplete outcome data } \\
\text { (attrition bias) } \\
\text { All outcomes }\end{array}$ & High risk & 17 participant dropouts \\
\hline $\begin{array}{l}\text { Selective reporting (re- } \\
\text { porting bias) }\end{array}$ & Low risk & All outcomes reported \\
\hline Other bias & Low risk & None identified \\
\hline
\end{tabular}

Lim 2009

\begin{tabular}{|c|c|}
\hline Methods & $\begin{array}{l}\text { Method of randomisation unclear: participants divided into } 2 \text { groups according to order of enrolment } \\
\text { Blinding of outcomes unclear } \\
\text { Analysis by ITT unclear } \\
\text { Balancing of prognostic baseline factors between treatment groups - not reported for dysphagia severi- } \\
\text { ty, only for previous treatment of pneumonia }\end{array}$ \\
\hline Participants & $\begin{array}{l}1 \text { centre in Korea } \\
22 \text { participants with CT or MRI confirmed stroke }<6 \text { months from onset } \\
\text { Mean age } 64 \text { years }\end{array}$ \\
\hline Interventions & $\begin{array}{l}\text { Rx: neuromuscular electrical stimulation }+ \text { thermal-tactile stimulation }(n=13) \\
\text { C: thermal-tactile stimulation }(n=9)\end{array}$ \\
\hline Outcomes & Swallow function scoring system, PAS and PTT \\
\hline
\end{tabular}


Lim 2009 (Continued)

Notes
Exclusions: inability to receive treatment for 1 hour, neurological disease other than stroke, combined behavioural disorder that interfered with administration of therapy, current illness or upper gastrointestinal disease, inability to give informed consent because of cognitive impairment or receptive aphasia

\section{Risk of bias}

\begin{tabular}{|c|c|c|}
\hline Bias & Authors' judgement & Support for judgement \\
\hline $\begin{array}{l}\text { Random sequence genera- } \\
\text { tion (selection bias) }\end{array}$ & High risk & Participants divided into 2 groups according to order of enrolment \\
\hline $\begin{array}{l}\text { Allocation concealment } \\
\text { (selection bias) }\end{array}$ & High risk & Not concealed \\
\hline $\begin{array}{l}\text { Blinding (performance } \\
\text { bias and detection bias) } \\
\text { All outcomes }\end{array}$ & Unclear risk & No details available \\
\hline $\begin{array}{l}\text { Blinding of participants } \\
\text { and personnel (perfor- } \\
\text { mance bias) } \\
\text { All outcomes }\end{array}$ & Unclear risk & No details available \\
\hline $\begin{array}{l}\text { Blinding of outcome as- } \\
\text { sessment (detection bias) } \\
\text { All outcomes }\end{array}$ & Low risk & $\begin{array}{l}\text { Doctor blinded to groups performed videofluoroscopic examination; mea- } \\
\text { sured PTT as well as swallow function scoring system and Rosenbek penetra- } \\
\text { tion aspiration scale. }\end{array}$ \\
\hline $\begin{array}{l}\text { Incomplete outcome data } \\
\text { (attrition bias) } \\
\text { All outcomes }\end{array}$ & High risk & $\begin{array}{l}36 \text { enrolled to the study. Only } 28 \text { participants completed the study ( } 16 \text { in the } \\
\text { experimental group and } 12 \text { in the control group) }\end{array}$ \\
\hline $\begin{array}{l}\text { Selective reporting (re- } \\
\text { porting bias) }\end{array}$ & Unclear risk & Swallow scores not fully reported (unclear on the range of median values) \\
\hline Other bias & Low risk & None identified \\
\hline
\end{tabular}

\section{Liu 2000}

\begin{tabular}{ll}
\hline Methods & Method of randomisation unclear \\
& Blinding of outcomes unclear \\
& Analysis by ITT unclear \\
& Balancing of prognostic baseline factors between treatment groups unclear \\
\hline Participants & 1 centre in China \\
& 84 participants with bulbar palsy and CT/MRI-documented stroke: 54 men, 30 women \\
& Age 50 to 78 years \\
Infarct 56, haemorrhage 28 & Enrolment within 2 months of stroke onset \\
\hline Interventions & Rx: acupuncture - Tiantu (CV 22), Lieque (LU 7), Zhaohai (KI 6) - once daily for 10 days (n=54) \\
\hline
\end{tabular}


Liu 2000 (Continued)

$$
C:(n=30)
$$

Outcomes Outcome: bulbar function (phonation, swallowing, cough reflex)

Timing unclear

Notes Exclusions: not given

\section{Risk of bias}

\begin{tabular}{lll}
\hline Bias & Authors' judgement & Support for judgement \\
\hline $\begin{array}{l}\text { Random sequence genera- } \\
\text { tion (selection bias) }\end{array}$ & Unclear risk & Method of randomisation unclear \\
\hline
\end{tabular}

tion (selection bias)

\begin{tabular}{ll}
\hline $\begin{array}{l}\text { Allocation concealment } \\
\text { (selection bias) }\end{array}$ & Unclear risk
\end{tabular}

\begin{tabular}{ll}
\hline Blinding (performance & Unclear risk \\
bias and detection bias) & \\
All outcomes & \\
\hline
\end{tabular}

Blinding of participants Unclear risk $\quad$ Blinding unclear
and personnel (perfor-
mance bias)
All outcomes

\begin{tabular}{lll}
\hline Blinding of outcome as- & Unclear risk & Blinding unclear \\
sessment (detection bias) &
\end{tabular}

All outcomes

\begin{tabular}{lll}
\hline $\begin{array}{l}\text { Incomplete outcome data } \\
\text { (attrition bias) } \\
\text { All outcomes }\end{array}$ & Unclear risk & Unclear \\
\hline $\begin{array}{l}\text { Selective reporting (re- } \\
\text { porting bias) }\end{array}$ & Unclear risk & Unclear - no clear aim of study \\
\hline Other bias & Unclear risk & Unclear \\
\hline
\end{tabular}

Liu 2004

\begin{tabular}{ll}
\hline Methods & RCT \\
\hline Participants & $\begin{array}{l}\text { 1 centre in China } \\
\text { women }\end{array}$ \\
& Age 40 to 80 years \\
& Infarct 72, haemorrhage 10 \\
& Enrolment within 6 months of stroke onset \\
\hline
\end{tabular}

Interventions $\quad$ Rx: scalp acupuncture + sublingual needling $(n=44)$


Liu 2004 (Continued)

$$
\text { C: scalp acupuncture + control needling }(n=38)
$$

Outcomes Recovery of function (swallowing food and water, movement of the tongue, disappearance of dyslalia and hoarseness)

Notes Exclusion: severe arrhythmia, coma, asthma, dilating myocardiopathy

\section{Risk of bias}

\begin{tabular}{|c|c|c|}
\hline Bias & Authors' judgement & Support for judgement \\
\hline $\begin{array}{l}\text { Random sequence genera- } \\
\text { tion (selection bias) }\end{array}$ & Unclear risk & Method of randomisation unclear \\
\hline $\begin{array}{l}\text { Allocation concealment } \\
\text { (selection bias) }\end{array}$ & Unclear risk & Unclear \\
\hline $\begin{array}{l}\text { Blinding (performance } \\
\text { bias and detection bias) } \\
\text { All outcomes }\end{array}$ & Unclear risk & Blinding unclear \\
\hline $\begin{array}{l}\text { Blinding of participants } \\
\text { and personnel (perfor- } \\
\text { mance bias) } \\
\text { All outcomes }\end{array}$ & Unclear risk & Blinding unclear \\
\hline $\begin{array}{l}\text { Blinding of outcome as- } \\
\text { sessment (detection bias) } \\
\text { All outcomes }\end{array}$ & Unclear risk & Blinding unclear \\
\hline $\begin{array}{l}\text { Incomplete outcome data } \\
\text { (attrition bias) } \\
\text { All outcomes }\end{array}$ & Unclear risk & Unclear \\
\hline $\begin{array}{l}\text { Selective reporting (re- } \\
\text { porting bias) }\end{array}$ & Unclear risk & Unclear aim of study - only 1 outcome reported \\
\hline Other bias & Unclear risk & Unclear \\
\hline
\end{tabular}

\section{Park 2012}

\begin{tabular}{ll}
\hline Methods & Computer-generated randomisation sequence \\
& Outcomes and participants blinded \\
\hline Participants & Study in Korea \\
& 20 participants with stroke > 1 month \\
& Baseline characteristics similar, except stimulation intensities. Unclear baseline degree of dysphagia \\
between groups & Dysphagia defined by videofluoroscopy
\end{tabular}

C: effortful swallow with infrahyoid sensory electrical stimulation (placebo stimulation) 
Park 2012 (Continued)

Outcomes Vertical laryngeal and hyoid movements, maximum width of UES opening, PAS

Notes Exclusions: subarachnoid haemorrhage, carotid stenosis, inability to overcome stimulation, which was
determined by observation and palpation

\section{Risk of bias}

\begin{tabular}{|c|c|c|}
\hline Bias & Authors' judgement & Support for judgement \\
\hline $\begin{array}{l}\text { Random sequence genera- } \\
\text { tion (selection bias) }\end{array}$ & Low risk & Computer-generated randomisation sequence \\
\hline $\begin{array}{l}\text { Allocation concealment } \\
\text { (selection bias) }\end{array}$ & Low risk & Automated assignment system \\
\hline $\begin{array}{l}\text { Blinding (performance } \\
\text { bias and detection bias) } \\
\text { All outcomes }\end{array}$ & Low risk & Participants and outcome assessors blinded \\
\hline $\begin{array}{l}\text { Blinding of participants } \\
\text { and personnel (perfor- } \\
\text { mance bias) } \\
\text { All outcomes }\end{array}$ & Low risk & Participants blinded \\
\hline $\begin{array}{l}\text { Blinding of outcome as- } \\
\text { sessment (detection bias) } \\
\text { All outcomes }\end{array}$ & Low risk & Outcome assessors blinded \\
\hline $\begin{array}{l}\text { Incomplete outcome data } \\
\text { (attrition bias) } \\
\text { All outcomes }\end{array}$ & Low risk & 2 participant dropouts ( 1 from each group) \\
\hline $\begin{array}{l}\text { Selective reporting (re- } \\
\text { porting bias) }\end{array}$ & Low risk & All outcomes reported \\
\hline Other bias & Low risk & None identified \\
\hline
\end{tabular}

\section{Park 2013}

\begin{tabular}{ll} 
Methods & Computer-generated randomisation sequence \\
& Outcomes and participants blinded \\
\hline Participants & $\begin{array}{l}\text { Study in Korea } \\
18 \text { participants with stroke }>1 \text { month } \\
\text { Baseline characteristics similar } \\
\text { Dysphagia confirmed by videofluoroscopy }\end{array}$ \\
\hline Interventions & Rx: active high-frequency rTMS (5 Hz) at the contralesional intact cortex \\
& C: sham rTMS \\
\hline Outcomes & VDS, PAS \\
\hline Notes & Exclusions: metal implants or a pacemaker in the body, history of seizures \\
\hline \hline
\end{tabular}


Park 2013 (Continued)

\section{Risk of bias}

\begin{tabular}{|c|c|c|}
\hline Bias & Authors' judgement & Support for judgement \\
\hline $\begin{array}{l}\text { Random sequence genera- } \\
\text { tion (selection bias) }\end{array}$ & Low risk & Computer-generated randomisation sequence \\
\hline $\begin{array}{l}\text { Allocation concealment } \\
\text { (selection bias) }\end{array}$ & Low risk & Automated assignment system \\
\hline $\begin{array}{l}\text { Blinding (performance } \\
\text { bias and detection bias) } \\
\text { All outcomes }\end{array}$ & Low risk & Participants and outcome assessors blinded \\
\hline $\begin{array}{l}\text { Blinding of participants } \\
\text { and personnel (perfor- } \\
\text { mance bias) } \\
\text { All outcomes }\end{array}$ & Low risk & Participants blinded \\
\hline $\begin{array}{l}\text { Blinding of outcome as- } \\
\text { sessment (detection bias) } \\
\text { All outcomes }\end{array}$ & Low risk & Outcome assessors blinded \\
\hline $\begin{array}{l}\text { Incomplete outcome data } \\
\text { (attrition bias) } \\
\text { All outcomes }\end{array}$ & Low risk & None lost to follow-up \\
\hline $\begin{array}{l}\text { Selective reporting (re- } \\
\text { porting bias) }\end{array}$ & Low risk & All outcomes reported \\
\hline Other bias & Low risk & None identified \\
\hline
\end{tabular}

Park 2016a (i)

\begin{tabular}{ll}
\hline Methods & Randomisation unclear \\
& Outcome assessor blinded \\
& (unilateral stimulation vs sham data set) \\
\hline Participants & centre in Korea \\
& 35 participants with subacute stroke defined as onset $<3$ months \\
& Swallowing dysfunction confirmed by videofluoroscopy \\
& Baseline characteristics similar \\
& 2 participants lost to follow-up \\
& Rx $1:$ unilateral stimulation group with $(10 \mathrm{~Hz}) \mathrm{rTMS}$ on ipsilesional cortex and sham on contralesional \\
cortex ( $=11)$ & Rx 2 : bilateral stimulation group with $(10 \mathrm{~Hz}) \mathrm{rTMS}$ on ipsilesional and contralesional cortex ( $\mathrm{n}=11)$ \\
C: sham rTMS over bilateral hemispheres $(\mathrm{n}=11)$ \\
Control group split into $\mathrm{n}=5$ for data set $1 \mathrm{and} \mathrm{n}=6$ for data set 2
\end{tabular}


Park 2016a (i) (Continued)

Therefore for this data set, unilateral stimulation $(n=11)$ vs sham stimulation $(n=5)$

\begin{tabular}{ll}
\hline Outcomes & Clinical Dysphagia Scale, Dysphagia Outcome and Severity Scale, PAS, VDS \\
\hline Notes & $\begin{array}{l}\text { Exclusion: history of swallowing problems caused by other underlying neurological diseases, such as } \\
\text { Parkinson's disease, dementia, or motor neuron disease; history of intractable seizure; metallic im- } \\
\text { plants in the brain }\end{array}$
\end{tabular}

\section{Risk of bias}

\begin{tabular}{|c|c|c|}
\hline Bias & Authors' judgement & Support for judgement \\
\hline $\begin{array}{l}\text { Random sequence genera- } \\
\text { tion (selection bias) }\end{array}$ & Unclear risk & Blinding unclear \\
\hline $\begin{array}{l}\text { Allocation concealment } \\
\text { (selection bias) }\end{array}$ & Unclear risk & Unclear \\
\hline $\begin{array}{l}\text { Blinding (performance } \\
\text { bias and detection bias) } \\
\text { All outcomes }\end{array}$ & High risk & Single-blinded (assessors only) \\
\hline $\begin{array}{l}\text { Blinding of participants } \\
\text { and personnel (perfor- } \\
\text { mance bias) } \\
\text { All outcomes }\end{array}$ & High risk & Reported only as single-blinded (assessors only) \\
\hline $\begin{array}{l}\text { Blinding of outcome as- } \\
\text { sessment (detection bias) } \\
\text { All outcomes }\end{array}$ & Low risk & Outcome assessors blinded \\
\hline $\begin{array}{l}\text { Incomplete outcome data } \\
\text { (attrition bias) } \\
\text { All outcomes }\end{array}$ & Low risk & 2 lost to follow-up \\
\hline $\begin{array}{l}\text { Selective reporting (re- } \\
\text { porting bias) }\end{array}$ & Low risk & All outcomes reported \\
\hline Other bias & Low risk & None identified \\
\hline
\end{tabular}

Park 2016a (ii)

\begin{tabular}{ll}
\hline Methods & $\begin{array}{l}\text { As per Park 2016a } \\
\text { (bilateral stimulation vs sham data set) }\end{array}$ \\
\hline Participants & As data set 1 \\
\hline Interventions & Bilateral stimulation $(n=11)$ vs sham stimulation $(n=6)$ \\
\hline Outcomes & As data set 1 \\
\hline Notes & As data set 1
\end{tabular}

\section{Risk of bias}


Park 2016a (ii) (Continued)

\begin{tabular}{|c|c|c|}
\hline Bias & Authors' judgement & Support for judgement \\
\hline $\begin{array}{l}\text { Random sequence genera- } \\
\text { tion (selection bias) }\end{array}$ & Unclear risk & Blinding unclear \\
\hline $\begin{array}{l}\text { Allocation concealment } \\
\text { (selection bias) }\end{array}$ & Unclear risk & Unclear \\
\hline $\begin{array}{l}\text { Blinding (performance } \\
\text { bias and detection bias) } \\
\text { All outcomes }\end{array}$ & High risk & Single-blinded (assessors only) \\
\hline $\begin{array}{l}\text { Blinding of participants } \\
\text { and personnel (perfor- } \\
\text { mance bias) } \\
\text { All outcomes }\end{array}$ & High risk & Reported only as single-blinded (assessors only) \\
\hline $\begin{array}{l}\text { Blinding of outcome as- } \\
\text { sessment (detection bias) } \\
\text { All outcomes }\end{array}$ & Low risk & Outcome assessors blinded \\
\hline $\begin{array}{l}\text { Incomplete outcome data } \\
\text { (attrition bias) } \\
\text { All outcomes }\end{array}$ & Low risk & 2 lost to follow-up \\
\hline $\begin{array}{l}\text { Selective reporting (re- } \\
\text { porting bias) }\end{array}$ & Low risk & All outcomes reported \\
\hline Other bias & Low risk & None identified \\
\hline
\end{tabular}

\section{Park 2016b}

Methods Randomisation by randomly selected envelopes containing a code specifying the group

Outcomes partially blinded (for VFSS only but not for SEMG evaluation)

\begin{tabular}{ll}
\hline Participants & 1 centre in Korea \\
& 33 participants with dysphagia (inclusion criteria states stroke onset within 6 months) \\
& Dysphagia confirmed by videofluoroscopy \\
& Baseline demographics and prognostic factors balanced \\
\hline Interventions & Rx: EMST with a $70 \%$ threshold value of maximal expiratory pressure, using an EMST device \\
C: training with sham device & Treatment for 4 weeks \\
\hline Outcomes & Swallow function using VFSS, PAS, Functional Oral Intake Scale \\
\hline Notes & $\begin{array}{l}\text { Exclusion: stroke before that resulting in dysphagia; severe oro-facial pain including trigeminal neu- } \\
\text { ropathy; significant malocclusion or facial asymmetry; unstable breathing and pulse; tracheostomy; se- } \\
\text { vere communication disorder such as severe aphasia; inadequate lip closure }\end{array}$ \\
\hline
\end{tabular}

\section{Risk of bias}


Park 2016b (Continued)

\section{Bias Authors' judgement Support for judgement}

Random sequence genera- Low risk Randomisation by randomly selected envelopes containing a code specifying
tion (selection bias) the group

\begin{tabular}{|c|c|c|}
\hline $\begin{array}{l}\text { Allocation concealment } \\
\text { (selection bias) }\end{array}$ & Low risk & Concealed by coded envelopes \\
\hline $\begin{array}{l}\text { Blinding (performance } \\
\text { bias and detection bias) } \\
\text { All outcomes }\end{array}$ & Unclear risk & Participant blinding unclear \\
\hline $\begin{array}{l}\text { Blinding of participants } \\
\text { and personnel (perfor- } \\
\text { mance bias) } \\
\text { All outcomes }\end{array}$ & Unclear risk & Unclear \\
\hline
\end{tabular}

\begin{tabular}{lll}
$\begin{array}{l}\text { Blinding of outcome as- } \\
\text { sessment (detection bias) } \\
\text { All outcomes }\end{array}$ & Low risk & $\begin{array}{l}\text { Outcomes partially blinded (surface EMG evaluation not blinded; however this } \\
\text { outcome not relevant in this review) }\end{array}$ \\
\hline
\end{tabular}

\begin{tabular}{lll}
\hline $\begin{array}{l}\text { Incomplete outcome data } \\
\text { (attrition bias) } \\
\text { All outcomes }\end{array}$ & High risk & 6 participants lost to follow-up \\
\hline $\begin{array}{l}\text { Selective reporting (re- } \\
\text { porting bias) }\end{array}$ & Low risk & All outcomes reported \\
\hline Other bias & Low risk & None identified \\
\hline
\end{tabular}

\section{Perez 1997}

$\begin{array}{ll}\text { Methods } & \text { Computerised randomisation } \\ & \text { Triple-blind trial; outcomes assessed by blinded therapist } \\ & \text { Analysis by ITT } \\ & \text { No cross-overs or losses to follow-up } \\ & 1 \text { participant withdrawn with heart failure (nifedipine group) } \\ & \text { Baseline prognostic factors balanced between treatment groups } \\ & 1 \text { centre in UK } \\ & 17 \text { participants; } 8 \text { men } \\ \text { Mean age } 77 \text { (SD } 7 \text { ) years } & \text { All first ischaemic stroke } \\ & 100 \% \text { CT } \\ \text { Enrolment } 2 \text { weeks after stroke }\end{array}$

Interventions

Rx: nifedipine (30 mg orally daily, Bayer, UK) $(n=8)$ 
Perez 1997 (Continued)

Pl: matching tablet; treatment for 4 weeks $(n=9)$

\begin{tabular}{ll} 
Outcomes & Primary outcome: clinical improvement in swallowing \\
& $\begin{array}{l}\text { Other outcomes: incidence of silent aspiration, pharyngeal transit time and response duration, swal- } \\
\text { lowing delay (all assessed by videofluoroscopy), death }\end{array}$ \\
\hline Notes & $\begin{array}{l}\text { Exclusions: inability to sit, high clinical risk of aspiration, receptive dysphasia, cognitive impairment, } \\
\text { pre-stroke dysphagia, existing neurological or psychiatric disease, current treatment with calcium } \\
\text { channel blockers or aminophylline }\end{array}$ \\
Follow-up: 4 weeks. 1 participant withdrawn with heart failure
\end{tabular}

\section{Risk of bias}

\begin{tabular}{|c|c|c|}
\hline Bias & Authors' judgement & Support for judgement \\
\hline $\begin{array}{l}\text { Random sequence genera- } \\
\text { tion (selection bias) }\end{array}$ & Low risk & Computerised randomisation \\
\hline $\begin{array}{l}\text { Allocation concealment } \\
\text { (selection bias) }\end{array}$ & Unclear risk & Not stated \\
\hline $\begin{array}{l}\text { Blinding (performance } \\
\text { bias and detection bias) } \\
\text { All outcomes }\end{array}$ & Low risk & Triple-blind trial \\
\hline $\begin{array}{l}\text { Blinding of participants } \\
\text { and personnel (perfor- } \\
\text { mance bias) } \\
\text { All outcomes }\end{array}$ & Low risk & Triple-blind trial \\
\hline $\begin{array}{l}\text { Blinding of outcome as- } \\
\text { sessment (detection bias) } \\
\text { All outcomes }\end{array}$ & Low risk & Outcomes assessed by blinded therapist \\
\hline $\begin{array}{l}\text { Incomplete outcome data } \\
\text { (attrition bias) } \\
\text { All outcomes }\end{array}$ & Low risk & $\begin{array}{l}1 \text { participant withdrawn with heart failure (nifedipine group) } \\
\text { No cross-overs }\end{array}$ \\
\hline $\begin{array}{l}\text { Selective reporting (re- } \\
\text { porting bias) }\end{array}$ & Low risk & All outcomes reported \\
\hline Other bias & Low risk & None identified \\
\hline
\end{tabular}

\section{Power 2006}

Methods Method of randomisation unclear

CT scans analysed by a neuroradiologist who was blinded to patients' clinical presentation and videofluoroscopic swallowing status

Baseline data not including dysphagia severity of baseline groups

\begin{tabular}{ll}
\hline Participants & 1 centre in UK \\
& 16 participants
\end{tabular}


Power 2006 (Continued)

Interventions $\quad$ Rx: actual electrical stimulation following threshold setting exercise to faucial pillars

C: single episode of sham electrical stimulation following threshold setting exercise

\begin{tabular}{ll}
\hline Outcomes & Changes on videofluoroscopy 60 minutes post intervention \\
\hline Notes & Exclusions: prior dysphagia, intercurrent illness, other neurological disease
\end{tabular}

\section{Risk of bias}

\begin{tabular}{|c|c|c|}
\hline Bias & Authors' judgement & Support for judgement \\
\hline $\begin{array}{l}\text { Random sequence genera- } \\
\text { tion (selection bias) }\end{array}$ & Unclear risk & Method of randomisation unclear \\
\hline $\begin{array}{l}\text { Allocation concealment } \\
\text { (selection bias) }\end{array}$ & Unclear risk & Unclear \\
\hline $\begin{array}{l}\text { Blinding (performance } \\
\text { bias and detection bias) } \\
\text { All outcomes }\end{array}$ & Unclear risk & Unclear \\
\hline $\begin{array}{l}\text { Blinding of participants } \\
\text { and personnel (perfor- } \\
\text { mance bias) } \\
\text { All outcomes }\end{array}$ & Unclear risk & Unclear \\
\hline $\begin{array}{l}\text { Blinding of outcome as- } \\
\text { sessment (detection bias) } \\
\text { All outcomes }\end{array}$ & Unclear risk & Unclear \\
\hline $\begin{array}{l}\text { Incomplete outcome data } \\
\text { (attrition bias) } \\
\text { All outcomes }\end{array}$ & Unclear risk & Unclear \\
\hline $\begin{array}{l}\text { Selective reporting (re- } \\
\text { porting bias) }\end{array}$ & Low risk & All outcomes reported \\
\hline Other bias & Low risk & None identified \\
\hline
\end{tabular}

\section{Shigematsu 2013}

\begin{tabular}{|c|c|}
\hline Methods & $\begin{array}{l}\text { Participants randomised using code numbers issued by coauthor } \\
\text { Outcomes blinded }\end{array}$ \\
\hline Participants & $\begin{array}{l}1 \text { centre in Japan } \\
20 \text { participants with stroke }>4 \text { weeks } \\
\text { Baseline characteristics similar } \\
\text { Clinical, video endoscopic, and videofluoroscopic evidence of dysphagia }\end{array}$ \\
\hline Interventions & $\begin{array}{l}\text { Rx: } 1-m A \text { anodal tDCS } \\
\text { C: sham tDCS }(n=10) \\
\text { Treatment for } 10 \text { days }\end{array}$ \\
\hline
\end{tabular}


Shigematsu 2013 (Continued)

Outcomes Dysphagia Outcome and Severity Scale, PAS, VFSS, video endoscopic evaluation of dysphagia

\begin{tabular}{ll}
\hline Notes & Exclusions: subarachnoid haemorrhage, history of epileptic seizures, severe consciousness distur- \\
bance, organic neck disease, history of surgery except for tracheotomy
\end{tabular}

\section{Risk of bias}

\begin{tabular}{|c|c|c|}
\hline Bias & Authors' judgement & Support for judgement \\
\hline $\begin{array}{l}\text { Random sequence genera- } \\
\text { tion (selection bias) }\end{array}$ & Low risk & Randomised via code numbers issued by coauthor \\
\hline $\begin{array}{l}\text { Allocation concealment } \\
\text { (selection bias) }\end{array}$ & Low risk & Allocation concealed by code numbers \\
\hline $\begin{array}{l}\text { Blinding (performance } \\
\text { bias and detection bias) } \\
\text { All outcomes }\end{array}$ & Unclear risk & Participant blinding unclear \\
\hline $\begin{array}{l}\text { Blinding of participants } \\
\text { and personnel (perfor- } \\
\text { mance bias) } \\
\text { All outcomes }\end{array}$ & Unclear risk & Unclear \\
\hline $\begin{array}{l}\text { Blinding of outcome as- } \\
\text { sessment (detection bias) } \\
\text { All outcomes }\end{array}$ & Low risk & $\begin{array}{l}\text { Outcomes blinded (rehabilitation doctor and speech-language hearing thera- } \\
\text { pists did not know participants' group allocation) }\end{array}$ \\
\hline $\begin{array}{l}\text { Incomplete outcome data } \\
\text { (attrition bias) } \\
\text { All outcomes }\end{array}$ & Low risk & None lost to follow-up \\
\hline $\begin{array}{l}\text { Selective reporting (re- } \\
\text { porting bias) }\end{array}$ & Low risk & $\begin{array}{l}\text { Results of the Dysphagia Outcome and Severity Scale reported pre-, post-, and } \\
\text { at 1-month follow-up }\end{array}$ \\
\hline Other bias & Low risk & None identified \\
\hline
\end{tabular}

Song 2004

\begin{tabular}{ll}
\hline Methods & Method of randomisation: random numbers table \\
& Allocation method and concealment unclear \\
\hline Participants & 1 centre in China \\
& 53 participants; 46 men \\
& All dysphagia identified by water swallow test \\
& Baseline characteristics reported as similar \\
\hline Interventions & Rx: nurse-led swallowing exercises, oral stimulation and oral care $(\mathrm{n}=29)$ \\
& C ( $n=24)$ \\
Follow-up: 1 month
\end{tabular}


Song 2004 (Continued)

Resolution of dysphagia by water swallow test and dietary ability, pneumonia rates

\begin{tabular}{|c|c|c|}
\hline Notes & Exclusions and wheth & ITT not stated \\
\hline \multicolumn{3}{|l|}{ Risk of bias } \\
\hline Bias & Authors' judgement & Support for judgement \\
\hline $\begin{array}{l}\text { Random sequence genera- } \\
\text { tion (selection bias) }\end{array}$ & Low risk & Method of randomisation: random numbers table \\
\hline $\begin{array}{l}\text { Allocation concealment } \\
\text { (selection bias) }\end{array}$ & Unclear risk & Unclear \\
\hline $\begin{array}{l}\text { Blinding (performance } \\
\text { bias and detection bias) } \\
\text { All outcomes }\end{array}$ & Unclear risk & Unclear \\
\hline $\begin{array}{l}\text { Blinding of participants } \\
\text { and personnel (perfor- } \\
\text { mance bias) } \\
\text { All outcomes }\end{array}$ & Unclear risk & Unclear \\
\hline $\begin{array}{l}\text { Blinding of outcome as- } \\
\text { sessment (detection bias) } \\
\text { All outcomes }\end{array}$ & Unclear risk & Unclear \\
\hline $\begin{array}{l}\text { Incomplete outcome data } \\
\text { (attrition bias) } \\
\text { All outcomes }\end{array}$ & Unclear risk & Unclear \\
\hline $\begin{array}{l}\text { Selective reporting (re- } \\
\text { porting bias) }\end{array}$ & Unclear risk & Unclear \\
\hline Other bias & Unclear risk & Translated from Chinese language \\
\hline
\end{tabular}

\section{STEPS 2016}

\begin{tabular}{ll}
\hline Methods & Computerised randomisation \\
& Single-blind; outcome assessor blinded \\
Analysis by ITT & Baseline characteristics balanced \\
\hline Participants & International, multi-centre trial \\
& 162 participants; 94 men \\
Mean age 74.4 years \\
Dysphagia identified clinically and by videofluoroscopy \\
Rx: active pharyngeal electrical stimulation \\
C: sham pharyngeal electrical stimulation
\end{tabular}


STEPS 2016 (Continued)

Follow-up: up to 12 weeks
Primary: change in PAS at 2 weeks from baseline

Secondary: safety outcomes, clinical dysphagia (Dysphagia Severity Rating Scale, PAS at 12 weeks), dependency (mRS), activities of daily living/disability (BI), impairment (NIHSS), health-related quality of life (European Quality of Life-5 Dimensions (EQ-5D), nutritional measures (weight, mid-arm circumference, and blood albumin))

\section{Risk of bias}

\begin{tabular}{|c|c|c|}
\hline Bias & Authors' judgement & Support for judgement \\
\hline $\begin{array}{l}\text { Random sequence genera- } \\
\text { tion (selection bias) }\end{array}$ & Low risk & Randomisation by computer-generated permuted blocks \\
\hline $\begin{array}{l}\text { Allocation concealment } \\
\text { (selection bias) }\end{array}$ & Unclear risk & Not reported \\
\hline $\begin{array}{l}\text { Blinding (performance } \\
\text { bias and detection bias) } \\
\text { All outcomes }\end{array}$ & Low risk & Researcher delivering the intervention not blinded \\
\hline $\begin{array}{l}\text { Blinding of participants } \\
\text { and personnel (perfor- } \\
\text { mance bias) } \\
\text { All outcomes }\end{array}$ & Low risk & Assessor and participant blinded \\
\hline $\begin{array}{l}\text { Blinding of outcome as- } \\
\text { sessment (detection bias) } \\
\text { All outcomes }\end{array}$ & Low risk & Outcome assessors blinded \\
\hline $\begin{array}{l}\text { Incomplete outcome data } \\
\text { (attrition bias) } \\
\text { All outcomes }\end{array}$ & High risk & 181 participants randomised; only 123 participants completed all 3 treatments \\
\hline $\begin{array}{l}\text { Selective reporting (re- } \\
\text { porting bias) }\end{array}$ & Low risk & All outcomes reported \\
\hline Other bias & Low risk & None identified \\
\hline
\end{tabular}

Terre 2015

\begin{tabular}{ll}
\hline Methods & Computerised randomisation \\
Double-blinded study \\
Outcome assessors blinded
\end{tabular}

\section{Participants} Study completed in Spain 
Terre 2015 (Continued)

20 participants with neurological oropharyngeal dysphagia (14 stroke participants in the posterior circulation; 6 with traumatic brain injury)

Baseline characteristics similar between groups

All within 5 months of diagnosis

Dysphagia identified by videofluoroscopy and Functional Oral Intake Scale

\begin{tabular}{ll}
\hline Interventions & Rx: active NMES with conventional therapy \\
& C: sham NMES with conventional therapy \\
\hline Outcomes & $\begin{array}{l}\text { Clinical, videofluoroscopic, and oesophageal manometric analyses of swallow; Functional Oral Intake } \\
\text { Scale }\end{array}$ \\
\hline Notes & $\begin{array}{l}\text { Exclusion: previous stroke or traumatic brain injury, previous dysphagia secondary to any other etiolo- } \\
\text { gy, other metabolic or neurological disease }\end{array}$
\end{tabular}

\section{Risk of bias}

\begin{tabular}{|c|c|c|}
\hline Bias & Authors' judgement & Support for judgement \\
\hline $\begin{array}{l}\text { Random sequence genera- } \\
\text { tion (selection bias) }\end{array}$ & Low risk & Computerised randomisation \\
\hline $\begin{array}{l}\text { Allocation concealment } \\
\text { (selection bias) }\end{array}$ & Unclear risk & Unclear \\
\hline $\begin{array}{l}\text { Blinding (performance } \\
\text { bias and detection bias) } \\
\text { All outcomes }\end{array}$ & Low risk & Double-blinded \\
\hline $\begin{array}{l}\text { Blinding of participants } \\
\text { and personnel (perfor- } \\
\text { mance bias) } \\
\text { All outcomes }\end{array}$ & Low risk & Participants and assessors blinded \\
\hline $\begin{array}{l}\text { Blinding of outcome as- } \\
\text { sessment (detection bias) } \\
\text { All outcomes }\end{array}$ & Low risk & Assessors blinded \\
\hline $\begin{array}{l}\text { Incomplete outcome data } \\
\text { (attrition bias) } \\
\text { All outcomes }\end{array}$ & Unclear risk & Unclear \\
\hline $\begin{array}{l}\text { Selective reporting (re- } \\
\text { porting bias) }\end{array}$ & Low risk & All outcomes reported \\
\hline Other bias & Low risk & None identified \\
\hline
\end{tabular}

Vasant 2016

$\begin{array}{ll}\text { Methods } & \text { Computerised randomisation } \\ \text { Single-blind trial; outcomes assessed by blinded therapist }\end{array}$


Vasant 2016 (Continued)

$$
\text { Analysis by ITT }
$$

\begin{tabular}{|c|c|}
\hline \multirow[t]{6}{*}{ Participants } & 3 centres in UK \\
\hline & 36 participants; 22 men \\
\hline & All dysphagia identified by bedside screening swallow test and videofluoroscopy \\
\hline & Baseline characteristics reported as similar \\
\hline & 1 participant withdrawn and lost to follow-up \\
\hline & Baseline prognostic factors similar between groups \\
\hline \multirow[t]{3}{*}{ Interventions } & Rx: pharyngeal electrical stimulation $n=18$ \\
\hline & C: sham $n=18$ \\
\hline & $\begin{array}{l}\text { Duration: } 3 \text { days } \\
\text { Follow-up: } 3 \text { months }\end{array}$ \\
\hline Outcomes & Death, swallow function, dysphagia \\
\hline Notes & $\begin{array}{l}\text { Exclusions: advanced dementia, other neurological conditions that may explain dysphagia, previous } \\
\text { history of dysphagia, presence of cardiac pacemaker or implanted cardiac defibrillator, diagnosis other } \\
\text { than stroke (e.g. brain tumour), significant structural abnormalities of the mouth or throat and requir- } \\
\text { ing continuous oxygen treatment }\end{array}$ \\
\hline
\end{tabular}

\section{Risk of bias}

\section{Bias}

\section{Authors' judgement Support for judgement}

Random sequence genera- Low risk Randomisation through a concealed computer programme tion (selection bias)

\begin{tabular}{lll}
\hline $\begin{array}{l}\text { Allocation concealment } \\
\text { (selection bias) }\end{array}$ & Low risk & Concealed via a computerised programme \\
\hline $\begin{array}{l}\text { Blinding (performance } \\
\text { bias and detection bias) } \\
\text { All outcomes }\end{array}$ & Low risk & Researcher delivering the intervention not blinded \\
\hline
\end{tabular}

Blinding of participants Low risk Participants and assessors blinded to group allocation
and personnel (perfor-
mance bias)
All outcomes

\begin{tabular}{lll}
\hline $\begin{array}{l}\text { Blinding of outcome as- } \\
\text { sessment (detection bias) } \\
\text { All outcomes }\end{array}$ & Low risk & Outcome assessors blinded \\
\hline $\begin{array}{l}\text { Incomplete outcome data } \\
\text { (attrition bias) }\end{array}$ & Low risk & $\begin{array}{l}\text { 1 participant lost to follow-up (withdrawn), 2 participants (1 from each group) } \\
\text { dill outcomes }\end{array}$
\end{tabular}

\begin{tabular}{lll}
\hline $\begin{array}{l}\text { Selective reporting (re- } \\
\text { porting bias) }\end{array}$ & Low risk & All outcomes reported \\
\hline Other bias & Low risk & None identified \\
\hline
\end{tabular}




\begin{tabular}{ll} 
Methods & Randomisation via a random numbers list generated by an independent statistician \\
& Double-blind \\
& Analysis by ITT unclear \\
\hline Participants & $\begin{array}{l}\text { centre in UK participants within } 7 \text { days of acute ischaemic or haemorrhagic stroke confirmed by CT scan of the } \\
\text { brain who required nasogastric feeds for }>24 \text { hours }\end{array}$ \\
Mean age: 78 & No significant differences between baseline characteristics \\
\hline Rx: 10 mg metoclopramide (10 mL) \\
C: 10 mL normal saline \\
Treatment duration: 21 days or until NGT no longer needed \\
\hline $\begin{array}{l}\text { Swallowing impairment using dysphagia outcome and severity scale } \\
\text { Outcomes }\end{array}$ \\
$\begin{array}{l}\text { Exclusions: signs and symptoms of pneumonia after stroke onset, history of chronic neurodegenerative } \\
\text { disease that could affect swallowing (e.g. Parkinson disease, motor neuron disease), oesophageal dis- } \\
\text { orders, contraindications to metoclopramide. }\end{array}$ \\
\hline Notes
\end{tabular}

\section{Risk of bias}

\begin{tabular}{|c|c|c|}
\hline Bias & Authors' judgement & Support for judgement \\
\hline $\begin{array}{l}\text { Random sequence genera- } \\
\text { tion (selection bias) }\end{array}$ & Low risk & Randomisation by numbers list generated by an independent statistician \\
\hline $\begin{array}{l}\text { Allocation concealment } \\
\text { (selection bias) }\end{array}$ & Low risk & Allocation sequence concealed from participants \\
\hline $\begin{array}{l}\text { Blinding (performance } \\
\text { bias and detection bias) } \\
\text { All outcomes }\end{array}$ & Low risk & Double-blind trial \\
\hline $\begin{array}{l}\text { Blinding of participants } \\
\text { and personnel (perfor- } \\
\text { mance bias) } \\
\text { All outcomes }\end{array}$ & Low risk & Double-blind trial \\
\hline $\begin{array}{l}\text { Blinding of outcome as- } \\
\text { sessment (detection bias) } \\
\text { All outcomes }\end{array}$ & Low risk & $\begin{array}{l}\text { Researcher and medical team involved in participants' care blinded to treat- } \\
\text { ment allocation }\end{array}$ \\
\hline $\begin{array}{l}\text { Incomplete outcome data } \\
\text { (attrition bias) } \\
\text { All outcomes }\end{array}$ & Low risk & All 60 participants analysed at end of trials (none excluded) \\
\hline $\begin{array}{l}\text { Selective reporting (re- } \\
\text { porting bias) }\end{array}$ & Low risk & All outcomes reported \\
\hline
\end{tabular}


Warusevitane 2015 (Continued)
Other bias
Low risk
None identified

Wei 2005

\begin{tabular}{ll} 
Methods & Method of randomisation unclear \\
& Outcomes blinded \\
\hline Participants & $\begin{array}{l}1 \text { centre in China } \\
68 \text { participants; timing post stroke unclear but suggests acute } \\
\text { Dysphagia defined by water swallow test }\end{array}$ \\
\hline
\end{tabular}

\begin{tabular}{ll}
\hline Interventions & Rx: Shuiti acupoint injection with stellate ganglion block for 40 days of treatment $(n=32)$ \\
C: standard medical care, which included some acupuncture $(n=33)$
\end{tabular}

\begin{tabular}{ll}
\hline Outcomes & Resolution of dysphagia: water swallow test score \\
& $\mathrm{BI}$ \\
& Chinese Neurological Score \\
& Fugl-Meyer Assessment \\
\hline Notes & Exclusions: needle phobia, organ failure, head and neck tumours \\
& Exclusions and dropouts accounted for but not analysed by ITT
\end{tabular}

\section{Risk of bias}

\begin{tabular}{|c|c|c|}
\hline Bias & Authors' judgement & Support for judgement \\
\hline $\begin{array}{l}\text { Random sequence genera- } \\
\text { tion (selection bias) }\end{array}$ & Unclear risk & Unclear \\
\hline $\begin{array}{l}\text { Allocation concealment } \\
\text { (selection bias) }\end{array}$ & Unclear risk & Unclear \\
\hline $\begin{array}{l}\text { Blinding (performance } \\
\text { bias and detection bias) } \\
\text { All outcomes }\end{array}$ & Unclear risk & Unclear \\
\hline $\begin{array}{l}\text { Blinding of participants } \\
\text { and personnel (perfor- } \\
\text { mance bias) } \\
\text { All outcomes }\end{array}$ & Unclear risk & Unclear \\
\hline $\begin{array}{l}\text { Blinding of outcome as- } \\
\text { sessment (detection bias) } \\
\text { All outcomes }\end{array}$ & Low risk & Outcomes blinded \\
\hline $\begin{array}{l}\text { Incomplete outcome data } \\
\text { (attrition bias) } \\
\text { All outcomes }\end{array}$ & Unclear risk & Unclear \\
\hline $\begin{array}{l}\text { Selective reporting (re- } \\
\text { porting bias) }\end{array}$ & Unclear risk & Unclear \\
\hline Other bias & Unclear risk & Translated from Chinese language \\
\hline
\end{tabular}


Xia 2011

\begin{tabular}{ll}
\hline Methods & Method of randomisation unclear \\
& Outcomes blinded \\
\hline Participants & $\begin{array}{l}1 \text { centre in China } \\
\text { Dysphagia defined by water swallow test }\end{array}$ \\
& Baseline characteristics similar \\
\hline Interventions & Rx 1: combined VitalStim therapy + conventional swallowing training ( $n=40)$ \\
& Rx 2: VitalStim therapy ( $n=40)$ \\
C: conventional swallowing training ( $\mathrm{n}=40)$ & For the purpose of this review, treatment group Rx 1 used as the treatment arm only \\
\hline Outcomes & VFSS, Standardised Swallowing Assessment (SSA), surface EMG, Swallowing Quality of Life (SWAL-QOL) \\
\hline Notes & Exclusion criteria not specified
\end{tabular}

\section{Risk of bias}

\begin{tabular}{|c|c|c|}
\hline Bias & Authors' judgement & Support for judgement \\
\hline $\begin{array}{l}\text { Random sequence genera- } \\
\text { tion (selection bias) }\end{array}$ & Unclear risk & Randomisation unclear \\
\hline $\begin{array}{l}\text { Allocation concealment } \\
\text { (selection bias) }\end{array}$ & Unclear risk & Unclear \\
\hline $\begin{array}{l}\text { Blinding (performance } \\
\text { bias and detection bias) } \\
\text { All outcomes }\end{array}$ & Unclear risk & Blinding unclear \\
\hline $\begin{array}{l}\text { Blinding of participants } \\
\text { and personnel (perfor- } \\
\text { mance bias) } \\
\text { All outcomes }\end{array}$ & Unclear risk & Unclear \\
\hline $\begin{array}{l}\text { Blinding of outcome as- } \\
\text { sessment (detection bias) } \\
\text { All outcomes }\end{array}$ & Unclear risk & Outcomes blinded \\
\hline $\begin{array}{l}\text { Incomplete outcome data } \\
\text { (attrition bias) } \\
\text { All outcomes }\end{array}$ & Unclear risk & Unclear \\
\hline $\begin{array}{l}\text { Selective reporting (re- } \\
\text { porting bias) }\end{array}$ & Low risk & All outcomes reported \\
\hline Other bias & Unclear risk & Unclear \\
\hline
\end{tabular}


Xia 2016a

\begin{tabular}{ll}
\hline Methods & Randomisation by random numbered tables \\
& Outcomes blinded \\
\hline Participants & $\begin{array}{l}1 \text { centre in China } \\
\text { stroke } \\
\text { Dysphagia identified by videofluoroscopy and Dysphagia Outcome Severity Scale }\end{array}$ \\
& No significant differences in baseline characteristics between groups \\
\hline Interventions & $\begin{array}{l}\text { Rx: combined acupuncture with standard swallowing training (n = 62) } \\
\text { C: standard swallowing training only ( } \mathrm{n}=62) \\
\text { Treatment for 4 weeks }\end{array}$ \\
\hline Outcomes & $\begin{array}{l}\text { Primary: Standardized Swallowing Assessment, Dysphagia Outcome Severity Scale } \\
\text { Secondary: Modified BI, Swallowing Quality of Life (SWAL-QOL) }\end{array}$ \\
\hline Notes & $\begin{array}{l}\text { Exclusion: presence of serious diseases of the liver, kidney, hematological system, or endocrine system; } \\
\text { psychiatric disorders; severe cognitive impairment; severe aphasia; other diseases that potentially im- } \\
\text { paired swallowing function, such as head and neck tumours, oesophageal neoplasms, craniocerebral } \\
\text { injury, myasthenia gravis, and Guillain-Barre syndrome }\end{array}$ \\
\hline
\end{tabular}

\section{Risk of bias}

\begin{tabular}{|c|c|c|}
\hline Bias & Authors' judgement & Support for judgement \\
\hline $\begin{array}{l}\text { Random sequence genera- } \\
\text { tion (selection bias) }\end{array}$ & Low risk & Randomisation by random numbers table \\
\hline $\begin{array}{l}\text { Allocation concealment } \\
\text { (selection bias) }\end{array}$ & Unclear risk & Unclear \\
\hline $\begin{array}{l}\text { Blinding (performance } \\
\text { bias and detection bias) } \\
\text { All outcomes }\end{array}$ & Unclear risk & Blinding unclear \\
\hline $\begin{array}{l}\text { Blinding of participants } \\
\text { and personnel (perfor- } \\
\text { mance bias) } \\
\text { All outcomes }\end{array}$ & Unclear risk & Unclear \\
\hline $\begin{array}{l}\text { Blinding of outcome as- } \\
\text { sessment (detection bias) } \\
\text { All outcomes }\end{array}$ & Low risk & Outcome assessors blinded \\
\hline $\begin{array}{l}\text { Incomplete outcome data } \\
\text { (attrition bias) } \\
\text { All outcomes }\end{array}$ & Low risk & 4 participant dropouts from study in total \\
\hline $\begin{array}{l}\text { Selective reporting (re- } \\
\text { porting bias) }\end{array}$ & Low risk & All outcomes reported \\
\hline Other bias & Low risk & None identified \\
\hline
\end{tabular}


Yuan 2003i

\begin{tabular}{ll}
\hline Methods & Method of randomisation unclear \\
& Blinding unclear \\
& (traditional liquid diet with swallowing therapy vs control) \\
\hline Participants & $\begin{array}{l}1 \text { centre in China } \\
64 \text { participants; timing unclear } \\
\text { All dysphagia as defined by Watian Swallow Test }\end{array}$ \\
\hline Interventions & $\begin{array}{l}\text { R1: enteral nutrition agent with thickener and swallowing therapy }(n=18) \\
\text { R2: traditional liquid diet and swallowing therapy }(n=22) . \text { This data set was split }(n=11)^{*} \\
\text { C: liquid diet only and no swallowing therapy }(n=24) \\
\text { (R1 and R2 had NGTs for an uncertain amount of time) } \\
\text { *Compared in data set } 1\end{array}$ \\
\hline Outcomes & Length of stay, pneumonia rates, nutritional measures, resolution of dysphagia (swallow test grade) \\
\hline Notes & $\begin{array}{l}\text { Exclusions: terminal illness, organ failure } \\
\text { Unclear if any blinding of interventions or outcomes occurred }\end{array}$ \\
\hline
\end{tabular}

\section{Risk of bias}

\begin{tabular}{|c|c|c|}
\hline Bias & Authors' judgement & Support for judgement \\
\hline $\begin{array}{l}\text { Random sequence genera- } \\
\text { tion (selection bias) }\end{array}$ & Unclear risk & Unclear \\
\hline $\begin{array}{l}\text { Allocation concealment } \\
\text { (selection bias) }\end{array}$ & Unclear risk & Unclear \\
\hline $\begin{array}{l}\text { Blinding (performance } \\
\text { bias and detection bias) } \\
\text { All outcomes }\end{array}$ & Unclear risk & Unclear \\
\hline $\begin{array}{l}\text { Blinding of participants } \\
\text { and personnel (perfor- } \\
\text { mance bias) } \\
\text { All outcomes }\end{array}$ & Unclear risk & Unclear \\
\hline $\begin{array}{l}\text { Blinding of outcome as- } \\
\text { sessment (detection bias) } \\
\text { All outcomes }\end{array}$ & Unclear risk & Unclear \\
\hline $\begin{array}{l}\text { Incomplete outcome data } \\
\text { (attrition bias) } \\
\text { All outcomes }\end{array}$ & Unclear risk & Unclear \\
\hline $\begin{array}{l}\text { Selective reporting (re- } \\
\text { porting bias) }\end{array}$ & Unclear risk & Unclear \\
\hline Other bias & Unclear risk & Translated from Chinese language \\
\hline
\end{tabular}


Yuan 2003ii

\begin{tabular}{ll}
\hline Methods & $\begin{array}{l}\text { (Enteral nutrition agent with thickener and swallowing therapy vs traditional liquid diet and swallow- } \\
\text { ing therapy data set) }\end{array}$ \\
\hline Participants & As data set 1 \\
\hline Interventions & $\begin{array}{l}\text { R1: enteral nutrition agent with thickener and swallowing therapy }(n=18) \\
\text { R2: traditional liquid diet and swallowing therapy }(n=22) . \text { This data set was split }(n=11)\end{array}$ \\
\hline Outcomes & As data set 1 \\
\hline Notes & -
\end{tabular}

\section{Risk of bias}

\begin{tabular}{|c|c|c|}
\hline Bias & Authors' judgement & Support for judgement \\
\hline $\begin{array}{l}\text { Random sequence genera- } \\
\text { tion (selection bias) }\end{array}$ & Unclear risk & Unclear \\
\hline $\begin{array}{l}\text { Allocation concealment } \\
\text { (selection bias) }\end{array}$ & Unclear risk & Unclear \\
\hline $\begin{array}{l}\text { Blinding (performance } \\
\text { bias and detection bias) } \\
\text { All outcomes }\end{array}$ & Unclear risk & Unclear \\
\hline $\begin{array}{l}\text { Blinding of participants } \\
\text { and personnel (perfor- } \\
\text { mance bias) } \\
\text { All outcomes }\end{array}$ & Unclear risk & Unclear \\
\hline $\begin{array}{l}\text { Blinding of outcome as- } \\
\text { sessment (detection bias) } \\
\text { All outcomes }\end{array}$ & Unclear risk & Unclear \\
\hline $\begin{array}{l}\text { Incomplete outcome data } \\
\text { (attrition bias) } \\
\text { All outcomes }\end{array}$ & Unclear risk & Unclear \\
\hline $\begin{array}{l}\text { Selective reporting (re- } \\
\text { porting bias) }\end{array}$ & Unclear risk & Unclear \\
\hline Other bias & Unclear risk & Unclear \\
\hline
\end{tabular}

\section{Zheng 2014}

\begin{tabular}{ll} 
Methods & Randomisation unclear \\
& Blinding unclear \\
\hline Participants & $\begin{array}{l}1 \text { centre in China } \\
88 \text { participants; onset of stroke within } 2 \text { weeks } \\
\text { Dysphagia identified by water swallow test } \\
\text { Baseline characteristics similar }\end{array}$
\end{tabular}


Zheng 2014 (Continued)

\begin{tabular}{ll} 
Interventions & Rx: individualised multi-disciplinary rehabilitation programme $(\mathrm{n}=44)$ \\
C: conventional rehabilitation programme $(\mathrm{n}=44)$ & Treatment for 4 weeks \\
\hline Outcomes & Swallowing function by the water swallow test \\
\hline Notes & Exclusion: comprehension difficulty, such as Wernicke aphasia
\end{tabular}

\section{Risk of bias}

\begin{tabular}{|c|c|c|}
\hline Bias & Authors' judgement & Support for judgement \\
\hline $\begin{array}{l}\text { Random sequence genera- } \\
\text { tion (selection bias) }\end{array}$ & Unclear risk & Unclear \\
\hline $\begin{array}{l}\text { Allocation concealment } \\
\text { (selection bias) }\end{array}$ & Unclear risk & Unclear \\
\hline $\begin{array}{l}\text { Blinding (performance } \\
\text { bias and detection bias) } \\
\text { All outcomes }\end{array}$ & Unclear risk & Unclear \\
\hline $\begin{array}{l}\text { Blinding of participants } \\
\text { and personnel (perfor- } \\
\text { mance bias) } \\
\text { All outcomes }\end{array}$ & Unclear risk & Unclear \\
\hline $\begin{array}{l}\text { Blinding of outcome as- } \\
\text { sessment (detection bias) } \\
\text { All outcomes }\end{array}$ & Unclear risk & Unclear \\
\hline $\begin{array}{l}\text { Incomplete outcome data } \\
\text { (attrition bias) } \\
\text { All outcomes }\end{array}$ & Unclear risk & Unclear \\
\hline $\begin{array}{l}\text { Selective reporting (re- } \\
\text { porting bias) }\end{array}$ & Low risk & All outcomes reported \\
\hline Other bias & Unclear risk & Unclear \\
\hline
\end{tabular}

ACE: angiotensin-converting enzyme

BI: Barthel Index

BSA: body surface area

C: control group

CT: computed tomography

EMG: electromyography

EMST: expiratory muscle strength training

EQ-5D: EuroQoL Group Quality of Life Questionnaire based on five dimensions

FDS: Functional Dysphagia Scale

FMA: Fugl-Meyer Assessment

Hz: Hertz

ITT: intention-to-treat analysis

LMI: lateral medullary infarction

MD: mean difference

MEPs: motor evoked potentials

MMSE: Mini Mental State Examination

MoCA: Montreal Cognitive Assessment 
MRI: magnetic resonance imaging

mRS: modified Rankin Scale

NGT: nasogastric tube

NIHSS: National Institutes of Health Stroke Scale

NMES: neuromuscular electrical stimulation

OR: odds ratio

PAS: Penetration Aspiration Scale

PEG: percutaneous endoscopic gastrostomy

PHAD: Paramatta Hospital's Assessment for Dysphagia score

Pl: placebo group

PTT: pharyngeal transit time

RBHOMS: Royal Brisbane Hospital Outcome Measure Scale

rTMS: repetitive transcranial magnetic stimulation

$\mathrm{Rx}$ : treatment group

SD: standard deviation

sEMG: surface electromyography

SLT: speech and language therapy

SPSS: Statistical Package for the Social Sciences

SSA: Standardised Swallow Assessment

SWAL-QOL: Swallowing Quality of Life Questionnaire

tDCS: transcranial direct current stimulation

UES: upper oesophageal sphincter

VDS: videofluoroscopic dysphagia scale

VFSS: videofluoroscopy swallow study

Characteristics of excluded studies [ordered by study ID]

\section{Study Reason for exclusion}

Akamatsu 2009 RCT assessing transcutaneous electrical stimulation vs control

12 participants with chronic stroke and episodes of choking while eating or drinking

Outcome: latency time in swallowing reflex

Excluded: no relevant outcome data

Aoki $2016 \quad$ Study looking at effect of implementing multi-disciplinary swallowing team approach in lowering the rate of pneumonia (between-team organisation vs after-team organisation)

Outcomes: rates of pneumonia

Excluded: not a true RCT

Arai $2003 \quad$
RCT
Group 1: cabergoline $(n=13)$
Group 2: amantadine $(n=14)$
Group 3: ACE inhibitor $(n=12)$
Group 4: control
Excluded: $(1)>3$ months post stroke; (2) definition of aspiration non-standard; (3) randomisation
unclear; (4) insufficient information

Beom 2011

Study comparing conventional dysphagia management (CDM) vs CDM with repetitive electrical stimulation of the suprahyoid muscles

Outcomes: swallow score

Excluded: not true RCT - non-concurrent comparative design 


\section{Study}

\section{Reason for exclusion}

Outcomes: swallow scores

Excluded: confounded - comparison between 2 treatment groups

Byeon 2016

Randomised trial comparing neuromuscular electrical stimulation vs thermal-tactile stimulation in subacute stroke patients with dysphagia

Outcomes: swallow scores (Functional Dysphagia Scale using VFSS)

Excluded: confounded - comparing 2 active treatments

RCT assessing neuromuscular electrical stimulation vs traditional swallowing therapy in 25 stroke patients with dysphagia

Outcomes: video radiographic swallowing evaluation, nutritional status, oral motor function test, visual analogue scale for self-evaluation of complaints

Excluded: (1) no available outcome data, (2) confounded, comparing 2 direct treatments

Randomised trial comparing tongue acupuncture vs conventional (neck and wrist) acupuncture in post-stroke dysphagia patients

Outcomes: dysphagia at end of trial, NIHSS, pneumonia

Excluded: (1) confounded - both groups received active treatment

RCT assessing effectiveness of electric stimulation vs traditional dysphagia therapy in participants with acute stroke ( $<6$ weeks)

Outcomes: American Speech Language Hearing Association National outcome measurement system swallowing level

Excluded: no available outcome data

\section{Chen 2002}

RCT assessing tongue acupuncture + ice massage + general medical treatment $(n=50)$ vs general medical treatment $(n=46)$ in acute dysphagic stroke patients

Outcome: dysphagia recovery assessed by videofluoroscopy

Excluded: no available outcome data

Chen 2003

RCT assessing electroacupuncture + rehabilitation $(n=34)$ vs rehabilitation alone $(n=34)$ in dysphagia patients with pseudobulbar palsy including stroke

Treated for 10 days

Outcome: dysphagia recovery after stroke

Excluded: no available outcome data

ChiCTR-ONC-17012326

RCT examining effects of acupuncture and rTMS for acute patients - duration of stroke and dysphagia between 1 and 6 months.

Outcomes: VFSS score

Excluded: confounded - comparing acupuncture and rTMS

ChiCTR-TRC-14005233

RCT comparing validity and safety of telerehabilitation (exercise rehabilitation and myoelectrical feedback) vs conventional rehabilitation in dysphagic patients with ischaemic cerebral stroke

Outcomes: Barthel Index assessment; NIHSS assessment; water drinking test assessment; surface electromyography 


\begin{tabular}{ll}
\hline Study & Reason for exclusion \\
\hline Excluded: confounded - comparing 2 active treatment groups \\
\hline RePippo 1994 & lowing techniques \\
& Group 1: patient/family choice of diet and food consistency $(\mathrm{n}=38)$ \\
& Group 2: therapist-prescribed diet and food consistency $(\mathrm{n}=38)$ \\
& Group 3: therapist-prescribed diet and food consistency, with daily reinforcement of compensato- \\
& ry swallowing techniques ( $\mathrm{n}=39)$ \\
& Outcomes: pneumonia, dehydration, caloric-nitrogen deficit, death \\
& Excluded: 3 active treatment groups with no control group (confounded)
\end{tabular}

Dou 2012

Randomised trial comparing effects of active vs passive balloon dilatation therapy on swallowing function in participants with cricopharyngeal dysfunction due to neurological disorders

Outcomes: swallow score, changes in upper oesophageal sphincter opening

Excluded: confounded - comparison between 2 active treatments

EChihira 2004
Group 1: theophylline 200 mg once daily
Group 2: placebo
N = 85 with 'mild to moderate' dysphagia (definition unclear)
Outcome: latency of swallow
Excluded: (1) nursing home residents (not acute), proportion of stroke patients not stated; (2) $>3$
months post stroke

Ebihira 2005

RCT

Group1: capsaicin troche $1.5 \mathrm{mcg}(\mathrm{n}=34)$

Group 2: placebo (blinded) ( $n=33$ ) for 4 weeks

Excluded: (1) 'predominantly' stroke (\% not stated) nursing home-dependent residents; (2) definition of dysphagia unclear; (3) > 3 months post stroke; (4) outcomes: latency of swallow not relevant to review

RCT evaluating effects of a designed physical therapy programme that consists of therapeutic physical exercises in addition to neuromuscular electrical stimulation on severe swallowing disorders (oropharyngeal dysphagia) in people with acute ischaemic cerebrovascular stroke

Outcomes: oral transit time, hyoid/laryngeal elevation, oesophageal sphincter opening, incidence of penetration and aspiration

Excluded: no available outcome data

TMS vs none

Outcome: pharyngeal electromyographic responses

Excluded: no relevant outcome data

Controlled clinical trial comparing 3 active interventions in 112 participants with aspiration Group 1: electrical stimulation

Group 2: thermal stimulation

Group 3: both - failed thermal stimulation followed by electrical stimulation

Outcome: regain oral intake

Excluded: (1) dysphagia of mixed aetiology (stroke ?\%); (2) not an RCT; (3) 2 active treatment groups with no control group (confounded) 


\begin{tabular}{|c|c|}
\hline Study & Reason for exclusion \\
\hline & $\begin{array}{l}\text { Outcome: swallow score } \\
\text { Excluded: (1) } 2 \text { active treatment groups with no control group (confounded) }\end{array}$ \\
\hline Hagg 2015 & $\begin{array}{l}\text { Prospective comparative study of } 2 \text { groups of post-stroke } 4 \text {-quadrant facial dysfunction and dys- } \\
\text { phagic patients - palatal plate training (2005-2008) vs training with oral IQoro }{ }^{\circledR}(2009-2012) \\
\text { Outcome: facial activity, swallow function } \\
\text { Excluded: (1) not a true RCT, (2) confounded - comparing } 2 \text { active treatment protocols }\end{array}$ \\
\hline Inui 2017 & $\begin{array}{l}\text { Quasi-experimental study to compare the incidence of pneumonia as a dependent variable be- } \\
\text { tween before (control) and after (intervention group) intervention with pyriform sinus suctioning } \\
\text { as an independent variable } \\
\text { Outcomes: incidence of pneumonia } \\
\text { Excluded: (1) not an RCT - not randomised }\end{array}$ \\
\hline ISRCTN18137204 & $\begin{array}{l}\text { RCT comparing electrical pharyngeal stimulation vs sham stimulation in severely dysphagic tra- } \\
\text { cheotomised stroke patients } \\
\text { Outcomes: intention to decannulate based on FEES performance; feeding status at discharge (dys- } \\
\text { phagia severity rating scale, functional oral intake scale); mRS; length of stay (ICU/hospital), time } \\
\text { from stimulation to discharge } \\
\text { Excluded: outcomes not relevant to the review }\end{array}$ \\
\hline
\end{tabular}

RCT assessing dose response of transcranial direct current stimulation for dysphagia after acute stroke

Outcome: swallow safety

Excluded: trial terminated due to problems in recruitment (according to study author)

RCT assessing effects of magnetic-ball sticking therapy at auricular points against acupuncture in 90 participants with chronic post-stroke dysphagia

Outcomes: swallow score (VFSS), PAS, pneumonia, malnutrition

Excluded: (1) confounded - all participants received treatment, (2) duration of stroke unknown

Study looking at effects of NMES according to electrode placement in stroke patients with dysphagia

Outcomes: videofluoroscopic dysphagia scale; PAS; functional oral intake scale

Excluded: (1) confounded (comparing electrode placement on suprahyoid vs infrahyoid), (2) time post onset unclear

\begin{tabular}{ll}
\hline Kikuchi 2014 & $\begin{array}{l}\text { Double-blind RCT on participants > 65 years old with stroke and dysphagia from } 2 \text { hospitals and } 2 \\
\text { nursing homes in Sendai, Japan }\end{array}$ \\
Group 1: press needles (Pyonex; Seirin Corporation, Shizuoka, Japan) at 2 points on the legs (ST36 \\
and KI3) \\
Group 2: sham patches on acupuncture points \\
Group 3: press needles on sham points \\
Excluded: no relevant outcomes \\
\hline Kabayashi $1996 \quad$ 20 healthy volunteers \\
\hline
\end{tabular}




\begin{tabular}{|c|c|}
\hline Study & Reason for exclusion \\
\hline & $\begin{array}{l}\text { Outcomes: swallowing latency } \\
\text { Excluded: (1) cross-over trial, (2) outcomes (swallowing latency) not relevant to this review, }(3)< \\
50 \% \text { stroke }\end{array}$ \\
\hline \multirow[t]{4}{*}{ Kulnik 2015} & Single-blind RCT in acute stroke patients \\
\hline & Expiratory training vs inspiratory training vs sham training \\
\hline & Outcomes: peak expiratory cough flow of maximal voluntary cough, pneumonia \\
\hline & Excluded: most participants do not have clinical dysphagia \\
\hline \multirow[t]{3}{*}{ Kushner 2013} & $\begin{array}{l}\text { Case-control study comparing the efficacy of NMES in addition to traditional dysphagia therapy in- } \\
\text { cluding progressive resistance training vs that of traditional dysphagia therapy/progressive resis- } \\
\text { tance training alone in participants with acute post-stroke dysphagia }\end{array}$ \\
\hline & Outcomes: swallow score, dysphagia at end of trial \\
\hline & Excluded: non-randomised trial \\
\hline
\end{tabular}

Single-blind clinical intervention trial comparing biomechanical properties of swallowing in brainstem stroke patients with dysphagia following modified balloon dilation therapy vs regular dysphagia therapy

Outcomes: Functional Oral Intake Scale, pharyngeal maximum pressures and duration, and upper oesophageal sphincter residual pressure and duration during swallowing were measured using high-resolution manometry

Excluded: non-randomised trial

RCT assessing traditional swallowing therapy or the Shaker exercise in participants with prolonged oropharyngeal dysphagia and aspiration

Outcomes: occurrence of aspiration (preswallow, intraswallow, postswallow) at 6-week follow-up period; occurrence of residue in the oral cavity, valleculae, or pyriform sinuses; Performance Status Scale for Diet

Excluded: (1) head and neck cancer and stroke (<50\%); (2) no relevant outcome data

Ma 2014 Randomised trial comparing acupoint injection, neural electrical stimulation, combination of both and swallowing training

Outcomes: swallow function using water swallow test

Excluded: confounded - comparing 3 active treatments

Randomised trial comparing effects of acupuncture and neck-skin electrical stimulation on dysphagia in participants with cerebral infarction

Outcomes: swallow function using water swallow test and food-intake scale

Excluded: confounded - comparing 2 active treatments

43 participants who were prescribed in-hospital dysphagia rehabilitation (most with history of stroke)

Sensory stimulation vs sham stimulation

Outcomes: cough latency times, functional oral intake scale scores, oral nutritional intake 


\begin{tabular}{ll}
\hline Study & Reason for exclusion \\
\hline Excluded: (1) majority of participants without stroke (48.8\% stroke participants), (2) timing of \\
stroke unclear
\end{tabular}

McCullough $2012 \quad$ Cross-over study investigating effects of intensive exercise using Mendelsohn manoeuvre on swallowing movement

All 18 participants with stroke and dysphagia

Outcomes: videofluoroscopic swallow assessment, swallow score

Excluded: (1) not a true RCT - cross-over design, (2) majority of participants chronic

McCullough $2013 \quad$ Cross-over study assessing effect of Mendelsohn manoeuvre on hyoid movement

All 18 participants with post-stroke dysphagia

Outcomes: assessment of hyoid movements, upper oesophageal sphincter opening

Excluded: (1) not a true RCT - cross-over design, (2) no relevant outcomes

Outcome: deglutitive thyrohyoid shortening before and after completion of assigned therapy regimen

Excluded: (1) no time of onset for stroke patients, (2) no separate results for stroke, (3) no relevant outcome data

RCT comparing effects of short-term inspiratory and expiratory muscle training on respiratory muscle strength in subacute stroke patients

Outcomes: respiratory muscle strength (maximum inspiratory and expiratory pressures)

Excluded: (1) outcomes not relevant to review, (2) not all participants had dysphagia

RCT comparing transcranial magnetic stimulation vs sham stimulation in 12 stoke participants with dysphagia

Outcome: pharyngeal electromyographic responses

Excluded: no relevant outcome data

RCT comparing transcranial magnetic stimulation vs pharyngeal electrical stimulation vs paired associative stimulation vs sham stimulation in 14 dysphagic stroke participants

Outcome: videofluoroscopic swallowing assessments

Excluded: no available outcome data 


\begin{tabular}{|c|c|}
\hline Study & Reason for exclusion \\
\hline \multirow[t]{3}{*}{ Nakayama 1998} & $\begin{array}{l}\text { RCT comparing } 5 \mathrm{mg} \text { imidapril or placebo in randomised, double-blind, cross-over design. Partici- } \\
\text { pants were normotensive patients with at least } 1 \text { episode of aspiration and healthy volunteers }\end{array}$ \\
\hline & Outcome: swallowing reflex \\
\hline & Excluded: no relevant outcome data \\
\hline \multirow[t]{3}{*}{ Nam 2012} & $\begin{array}{l}\text { Randomised trial comparing } 2 \text { neuromuscular stimulation techniques (VitalStim vs Stimplus DP } \\
\text { 200) }\end{array}$ \\
\hline & Outcomes: swallow function using videofluoroscopic swallowing studies \\
\hline & Excluded: confounded - comparison of 2 treatment groups \\
\hline \multirow[t]{2}{*}{ NCT00376506a } & $\begin{array}{l}\text { Implanted neuroprosthesis (neuro control implantable receiver-stimulator) to stimulate the laryn- } \\
\text { geal nerve vs sensory training in dysphagic participants including stroke }>6 \text { months post onset }\end{array}$ \\
\hline & Excluded: (1) no control group, 2 active groups compared, (2) no outcome data \\
\hline \multirow[t]{3}{*}{ NCT00376506b } & $\begin{array}{l}\text { RCT assessing intramuscular stimulation device implanted in the neck vs vibrotactile stimulation of } \\
\text { the throat in } 20 \text { participants with dysphagia secondary to stroke or chronic neurological disease }\end{array}$ \\
\hline & $\begin{array}{l}\text { Outcome: swallowing safety for } 10 \mathrm{~mL} \text { of thin liquid and } 5 \mathrm{~mL} \text { of pudding with and without stimula- } \\
\text { tion }\end{array}$ \\
\hline & Excluded: comparing 2 active treatments vs no control (confounded) \\
\hline
\end{tabular}

NCT01971320 Single-blind RCT comparing active vs fake Urostim I stimulation in hemispheric stroke patients with oropharyngeal dysphagia

Outcomes: evaluation of oropharyngeal dysphagia symptoms

Excluded: no outcome data as trial terminated due to lack of recruitment

Nishiyama $2010 \quad$ RCT comparing nicergoline (15 mg tds) vs control in 50 ischaemic stroke patients

Outcome: substance P level

Excluded: no relevant outcome data

Ortega 2016

RCT comparing 2 x 10-day treatment groups (transient receptor potential vanilloid 1 agonist vs transcutaneous sensory electrical stimulation)

Outcomes: swallow function (videofluoroscopic), dysphagia at end of trial

Excluded: (1) < 50\% participants with stroke - duration unknown, (2) confounded - comparing 2 active treatments

Permsirivanich 2009

Group 1: NMES $(\mathrm{n}=12)$

Group 2: rehabilitation swallowing therapy $(n=11)$

All stroke

Excluded: confounded, i.e. comparison of 2 active treatments post-stroke dysphagia: a further group of participants who were not dysphagic for liquids and who were given normal fluids compared with RCT 


\section{$\begin{array}{ll}\text { Study Reason for exclusion } & \text { Ren }\end{array}$}

Outcome: development of chest infection and dehydration

Excluded: no control group - 2 interventional groups were compared in the RCT

Pryor 2011 RCT comparing NMSE vs vibrotactile stimulation in dysphagic participants

Outcomes: swallow function, PAS

Excluded: (1) mixed patient population, (2) confounded - comparison of 2 active interventions

Reidnauer 2006

RCT comparing vital stimulation (and electrotherapy intervention) vs traditional treatment in poststroke participants with dysphagia

Outcomes: swallow scores

Excluded: no available outcome data

Rofes 2014

Double-blind RCT comparing effects of 2 doses of piperine (dual TRPV1/TRPA1 agonist) on the swallow response of dysphagic participants

Participants were randomised into 2 groups: 1 group received $150 \mathrm{IM}$ piperine and the other group received $1 \mathrm{mM}$

Outcome: PAS, swallowing analysis with videofluoroscopic images

Excluded: dose-response trial - all groups received treatment (either low or high dose of piperine)

Randomised cross-over trial assessing thermal stimulation in 7 male dysphagic participants with multiple previous strokes

Outcome: duration of stage transition

Excluded: (1) cross-over trial, (2) most participants recruited > 3 months after stroke onset, (3) randomisation status unclear

Randomised cross-over trial assessing thermal stimulation in 23 dysphagic participants with multiple previous strokes

Outcome: duration of stage transition, total swallow duration

Excluded: (1) cross-over trial, (2) 14 participants recruited > 3 months after stroke onset

Dose comparison RCT of thermal stimulation (150, 300, 450, 600 trials per week) in 45 dysphagic stroke participants recruited within 12 weeks

Outcome: number of trials delivered, treatment time, duration of stage transition, aspiration (PAS)

Excluded: no control group

Interventional study comparing effects of carbonated thin liquids vs non-carbonated thin liquids on oropharyngeal swallowing in adults with neurogenic dysphagia

Outcomes: oral transit time, pharyngeal transit time, PAS

Excluded: (1) non-RCT, (2) many participants with chronic stroke (> 6 months)

\begin{tabular}{ll} 
Seki 2005 & Randomised trial \\
& Group 1: acupuncture $(\mathrm{n}=18)$ \\
& Group 2: no intervention $(\mathrm{n}=14)$ \\
& Excluded: (1) incomplete outcome data, (2) time from stroke unclear \\
\hline Shaker 2002a & RCT comparing head-raising exercise vs sham exercise in 27 dysphagic participants \\
& Outcomes: upper oesophageal sphincter function, functional swallow status \\
& Excluded: (1) dysphagia of mixed aetiology (cerebrovascular disease 56\%), (2) most participants \\
& recruited $>3$ months after stroke onset, (3) individual patient data unavailable, so not possible to \\
& analyse subgroup of appropriate participants
\end{tabular}




\section{Study}

She 2014

\section{Reason for exclusion}

RCT comparing acupuncture in 8 neck-occiput points vs meridian points

Outcomes: speech and swallowing dysfunction at end of trial

Excluded: (1) confounded - comparing 2 different treatment groups
RCT comparing acupuncture vs sham acupuncture for 16 sessions in participants with dysphagia due to recent stroke

Outcomes: tube feeding, pneumonia, mortality, each at 6 months

Excluded: no outcome data

\section{Steele 2016}

RCT comparing 2 treatment protocols: tongue pressure profile training or tongue pressure strength-and-accuracy training

Outcomes: swallow function

Excluded: confounded - comparison between 2 treatment protocols

\section{Sukthankar 1994}

RCT assessing swallowing therapy (biofeedback) in 9 participants with dysphagia secondary to stroke or head injury

Group 1: regular therapy $(n=4)$

Group 2: regular therapy and oral exercises $(n=2)$

Group 3: regular therapy and oral exercises with visual and audio biofeedback $(n=3)$

Excluded: (1) dysphagia of mixed aetiology, (2) outcome measures (tongue and lip motor force) not relevant to this review

Suntrup 2015

RCT comparing electrical pharyngeal stimulation vs sham stimulation (control) in severely dysphagic tracheotomised stroke participants

Outcomes: ability to decannulate based on FEES performance; feeding status at discharge (FOIS); $\mathrm{mRS}$; length of stay (ICU/hospital) and time from stimulation to discharge

Excluded: outcomes (decannulation) not relevant to review (only data regarding decannulation available before trial unblinded)

Randomised trial investigating the relationship between body position during nasogastric feed and aspiration pneumonia in acute stroke participants

Outcomes: aspiration pneumonia rates

Excluded: pseudo-randomised study; assessment of body position

\section{Tai 2014}

Quasi-experimental trial to investigate effectiveness of the chin-down swallowing technique in improvement of dysphagia in stroke participants

Outcomes: Dysphasia Assessment Scale and Swallow Self-assessment

Excluded: not an RCT - not randomised

RCT assessing swallowing function using cilostazol vs placebo in 48 participants with dysphagia secondary to stroke

Outcome: swallowing function

Excluded: (1) onset of stroke to randomisation, 1 to 6 months, (2) cross-over study, no access to data on the first phase 


\section{Study}

Terre 2012

\section{Reason for exclusion}

Randomised, alternating, cross-over study assessing effectiveness of chin-down posture in preventing aspiration in participants with neurogenic dysphagia secondary to acquired brain injury

Outcomes: aspiration prevention

Excluded: (1) pseudo-randomised study, (2) assessment of posture
Non-randomised interventional study comparing NMES and conventional treatment vs conventional treatment only

Outcomes: swallow scores (VDS, FOIS), hyoid and laryngeal displacement

Excluded: not an RCT - not randomised
Ueda 2004

21 participants

Group 1: functional swallowing training $(n=11)$

Group 2: oral care $(n=11)$ in nursing home residents (\% stroke unknown) who are tube fed

Excluded: (1) <50\% stroke, (2) non-acute, (3) randomisation unclear

Excluded: (1) insufficient data, (2) outcome methods unclear

Wang $2016 \quad$ Randomised interventional trial comparing differences in effects between awn-like needle at Tiantu (CV 22) and filiform needle for dysphagia after cerebral infarction

Outcomes: standard swallowing assessment scale and modified Bathel index

Exlcuded: confounded - comparing 2 different treatment groups

\section{Xia 2016}

RCT with 130 participants with post-stroke dysphagia

In treatment group, acupuncture based on meridian differentiation was adopted. The main acupoints were Neiguan (PC 6), Shuigou (GV 26), Sanyinjiao (SP 6), Fengchi (GB 20), Lianquan (CV 23), Jialianquan (Extra), Jinjin (EX-HN 12), Yuye (EX-HN 13), etc.

Control group: points were selected $5 \mathrm{~cm}$ lateral to the acupoints used in the observation groups and stimulated with shallow puncture

Outcomes: standardised swallowing assessment, VFSS, modified Barthel Index and swallowing-related quality of life (SWAL-QOL)

Excluded: confounded - comparing 2 treatments

RCT comparing different depth of Chonggu (EX-HN 27) by electroacupuncture in participants with dysphagia after stroke

Chonggu (EX-HN 27) deep insertion group $(n=99)$

Chonggu (EX-HN 27) shallow insertion group $(n=94)$

Traditional acupuncture group $(\mathrm{n}=90)$

Outcomes: Kubota's Water Drinking Test Scale, standard swallowing function scale, and TCM Scale of Dysphagia After Stroke

Excluded: no available outcome data 


\begin{tabular}{|c|c|}
\hline Study & Reason for exclusion \\
\hline & $\begin{array}{l}\text { Low-frequency }(2 \mathrm{~Hz}) \text { electroacupuncture group vs high-frequency }(100 \mathrm{~Hz}) \text { electroacupuncture } \\
\text { group }\end{array}$ \\
\hline & Outcomes: VFSS, standardised swallowing assessment \\
\hline & Excluded: not an RCT - dose-response study (no control group) \\
\hline \multirow[t]{4}{*}{ Zhang 2018b } & $\begin{array}{l}\text { Randomised interventional trial to assess clinical improvement of nursing intervention in swallow- } \\
\text { ing dysfunction of elderly stroke participants }\end{array}$ \\
\hline & $\begin{array}{l}\text { Conventional nursing service vs nursing interventions (psychological intervention, health educa- } \\
\text { tion, rehabilitation exercises, diet intervention) }\end{array}$ \\
\hline & Outcomes: dysphagia at end of trial, functional outcomes (GQOL-74) \\
\hline & Excluded: confounded - comparing 2 different treatment groups \\
\hline \multirow[t]{5}{*}{ Zhao 2015} & Randomised trial of participants with stroke and swallowing disorders \\
\hline & Group A: normal acupuncture \\
\hline & $\begin{array}{l}\text { Group B: NMES combined with acupuncture with uniform reinforcing-reducing manipulation as } \\
\text { well as the piercing and blood-letting method }\end{array}$ \\
\hline & Outcomes: Kubota water test, dysphagia at end of trial \\
\hline & Excluded: confounded - comparison between 2 treatment groups \\
\hline
\end{tabular}

ACE: angiotensin-converting enzyme

CDM: conventional dysphagia management

CXR: chest $x$-ray

FEES: Fibreoptic Endoscopic Evaluation of Swallowing

FIM: Functional Independence Measure

FOIS: Functional Oral Intake Scale

GQOL-74: Generic Quality of Life Inventory

ICU: intensive care unit

IOro ${ }^{\circledR}$ : Orofacial device

mRS: modified Rankin Scale

NGT: nasogastric tube

NIHSS: National Institutes of Health Stroke Scale

NMES: neuromuscular electrical stimulation

PEG: percutaneous endoscopic gastrostomy

RCT: randomised controlled trial

rTMS: repetitive transcranial magnetic stimulation

SAH: subarachnoid haemorrhage

SWAL-QOL: Swallowing Quality of Life Questionnaire

TCM: Traditional Chinese Medicine

TMS: transcranial magnetic stimulation

VDS: videofluoroscopic dysphagia scale

VFSS: videofluoroscopy swallow study

Characteristics of studies awaiting assessment [ordered by study ID]

Azimov 2017

Methods RCT although randomisation method unclear


Azimov 2017 (Continued)

Interventions

Experimental group: amantadine $(200 \mathrm{mg} / \mathrm{d})$ and levodopa $(125 \mathrm{mg} / \mathrm{d})$ after standard treatment $(\mathrm{n}$ $=17$ )

Control group: standard treatment, including citicoline and anticholinesterase $(n=17)$

Outcomes

PAS divided into group PAS score 2 to 4 and group PAS score 5 to 7 ; recheck after 2 months

Notes

Study completed; awaiting full published data

\section{Carnaby 2012}

\begin{tabular}{ll}
\hline Methods & RCT \\
\hline Participants & 53 stroke participants from a subacute rehabilitation facility \\
\hline Interventions & Group 1: usual care \\
& $\begin{array}{l}\text { Group 2: McNeill Dysphagia Therapy plus sham NMES } \\
\text { Group 3: McNeill Dysphagia Therapy plus active NMES }\end{array}$ \\
\hline Outcomes & $\begin{array}{l}\text { Increase of 10 or more points on the Mann Assessment of Swallowing and improvement of 2 or } \\
\text { more scale points on the Functional Oral Intake Scale, without significant weight loss or complica- } \\
\text { tion }\end{array}$ \\
\hline Notes & In the process of retrieving full-text article and data \\
\hline
\end{tabular}

\section{Chang 2014}

\begin{tabular}{ll}
\hline Methods & RCT \\
\hline Participants & 74 participants with dysphagia after stroke \\
\hline Interventions & Functional electrical stimulation vs a combination of electrical stimulation and acupuncture \\
\hline Outcomes & Swallow score, removal rate of nasogastric tube \\
\hline Notes & In the process of retrieving full-text article \\
\hline
\end{tabular}

Chaudhuri 2008

\begin{tabular}{ll}
\hline Methods & RCT \\
\hline Participants & People with stroke and dysphagia \\
\hline Interventions & $\begin{array}{l}\text { Traditional dysphagia treatment vs combined neuromuscular electrical stimulation and traditional } \\
\text { treatment }\end{array}$ \\
\hline Outcomes & Swallow score (ASHA NOMS) \\
\hline Notes & Awaiting published data (full text) \\
\hline
\end{tabular}


Chen 2017

\begin{tabular}{ll}
\hline Methods & RCT \\
\hline Participants & People with dysphagia due to stroke (onset 2 to 7 days) \\
\hline Interventions & Levetiracetam (Keppra) vs carbidopa/levodopa (Sinemet) vs placebo \\
\hline Outcomes & Qualitative and quantitative swallow function \\
\hline Notes & Study published; in the process of extracting data \\
\hline
\end{tabular}

\section{Cheng 2005}

\begin{tabular}{ll}
\hline Methods & RCT \\
\hline Participants & People with Ischaemic stroke with pseudobulbar palsy \\
\hline Interventions & Early throat muscle training vs control \\
\hline Outcomes & Effects on vertebral and basilar artery blood flow \\
\hline Notes & In the process of retrieving full-text article \\
\hline
\end{tabular}

Cheng 2014

\begin{tabular}{ll}
\hline Methods & RCT \\
\hline Participants & 180 participants with post-stroke dysphagia \\
\hline Interventions & Group 1 (Acupuncture A): acupuncture at Lianquan (CV 23) \\
& Group 2 (Acupuncture B): acupuncture at Hegu (LI 4) and Neiguan (PC 6) \\
& Group 3 (Control): rehabilitation group \\
\hline Outcomes & NIHSS scores, VFSS scale, pneumonia, clinical efficacy \\
\hline Notes & In the process of retrieving full-text article \\
\hline
\end{tabular}

\section{ChicTR-TRC-07000010}

\begin{tabular}{ll}
\hline Methods & RCT \\
\hline Participants & People with dysphagia in the convalescence phase of stroke (2 and 6 months) \\
\hline Interventions & $\begin{array}{l}\text { Combination of body acupuncture, scalp acupuncture, and electroacupuncture vs routine rehabili- } \\
\text { tation training }\end{array}$ \\
\hline Outcomes & Safety and tolerability of acupuncture \\
\hline
\end{tabular}


ChiCTR-TRC-07000010 (Continued)

Notes Study completed; awaiting published data

ChicTR-TRC-08000463

\begin{tabular}{ll}
\hline Methods & RCT \\
\hline Participants & People with stroke 2 to 60 days from onset \\
\hline Interventions & Dysphagia therapeutic apparatus on acupoints vs regular dysphagia rehabilitation vs both \\
\hline Outcomes & Swallowing function and mastication function \\
\hline Notes & Study completed; awaiting published data \\
\hline
\end{tabular}

\section{ChiCTR-TRC-14004235}

\begin{tabular}{ll}
\hline Methods & RCT \\
\hline Participants & People with dysphagia symptoms appearing within 1 to 6 months after stroke \\
\hline Interventions & Modified Dihuang Yinzi Decoction (herb treatment group) vs control \\
\hline Outcomes & Swallowing rehabilitation improvement diagnosed by videofluoroscopy, adverse events \\
\hline Notes & Study completed; awaiting published data \\
\hline
\end{tabular}

\section{ChicTR-TRC-14004955}

\begin{tabular}{ll}
\hline Methods & Randomised parallel controlled trial \\
\hline Participants & $\begin{array}{l}60 \text { people with stroke; onset of stroke at least } 2 \text { times but occurrence of stroke at least } 1 \text { month be- } \\
\text { fore admission }\end{array}$ \\
\hline Interventions & $\begin{array}{l}\text { Manipulation + sham tDCS } \\
\text { Manipulation + tDCS }\end{array}$ \\
\hline Outcomes & $\begin{array}{l}\text { Lingual movement; buccofacial apraxia; Modified Assessment of Swallowing Ability; VFSS; EEG } \\
\text { non-linear analysis }\end{array}$ \\
\hline Notes & Study likely completed; website not updated; awaiting published data \\
\hline
\end{tabular}

\section{Choi 2017}

\begin{tabular}{lc}
\hline Methods & RCT \\
\hline Participants & Stroke survivors with dysphagia \\
\hline Interventions & Experimental group: Shaker exercise + conventional therapy $(\mathrm{n}=16)$ \\
\hline $\begin{array}{l}\text { Swallowing therapy for dysphagia in acute and subacute stroke (Review) } \\
\text { Copyright @ } 2018 \text { The Cochrane Collaboration. Published by John Wiley \& Sons, Ltd. }\end{array}$
\end{tabular}


Choi 2017 (Continued)

Control group: conventional therapy $(n=16)$

\begin{tabular}{ll}
\hline Outcomes & PAS and oral diet level \\
\hline Notes & In the process of retrieving full-text article
\end{tabular}

Chu 2017

\begin{tabular}{|c|c|}
\hline Methods & $\mathrm{RCT}$ \\
\hline Participants & Dysphagia patients with pseudobulbar palsy \\
\hline Interventions & $\begin{array}{l}\text { Basic treatment vs GAO neck acupuncture at Fengchi (GB 20), Yiming (EX-HN 14), Gongxue (Extra), } \\
\text { Lianquan (CV 23), Wai Jinjin Yuye (Extra), Tunyan (Extra), Zhiqiang (Extra), Fayin (Extra) with basic } \\
\text { treatment }\end{array}$ \\
\hline Outcomes & $\begin{array}{l}\text { Repetitive saliva-swallowing test, standardised swallowing assessment, swallow quality-of-life } \\
\text { questionnaire }\end{array}$ \\
\hline Notes & In the process of retrieving full-text article \\
\hline \multicolumn{2}{|l|}{ de Fraga 2017} \\
\hline Methods & $\mathrm{RCT}$ \\
\hline Participants & 10 participants with ischaemic stroke and speech therapy-diagnosed oropharyngeal dysphagia \\
\hline \multirow[t]{2}{*}{ Interventions } & Rx: myofunctional therapy plus voice therapy \\
\hline & C: myofunctional therapy only \\
\hline Outcomes & Swallow function \\
\hline Notes & Study published; in the process of extracting data \\
\hline
\end{tabular}

\section{Eom 2017}

\begin{tabular}{ll}
\hline Methods & RCT \\
\hline Participants & Stroke patients with oropharyngeal dysphagia \\
\hline Interventions & Resistance expiratory muscle strength training vs sham expiratory muscle strength training \\
\hline Outcomes & Videofluoroscopic dysphagia scale, PAS \\
\hline Notes & In the process of retrieving full-text article \\
\hline
\end{tabular}


Erfmann 2017

\begin{tabular}{ll}
\hline Methods & RCT \\
\hline Participants & Subacute stroke patients with oropharyngeal dysphagia \\
\hline Interventions & Expiratory muscle strength training; no further details available \\
\hline Outcomes & No further details available at the time \\
\hline Notes & In the process of retrieving text \\
\hline
\end{tabular}

Fan 2007

\begin{tabular}{ll}
\hline Methods & RCT \\
\hline Participants & 60 post-stroke patients with dysphagia \\
\hline Interventions & Experimental group: acupuncture plus Western drugs \\
& Control group: Western drugs \\
\hline Outcomes & Swallowing test \\
\hline Notes & In the process of retrieving full-text article \\
\hline
\end{tabular}

Feng 2016

\begin{tabular}{ll}
\hline Methods & RCT \\
\hline Participants & 60 cases of post-stroke dysphagia \\
\hline Interventions & Rx: deep acupuncture at Lianquan (CV 23) and Yifeng (TE 17) with swallowing training \\
& C: swallowing training only \\
\hline Outcomes & VFSS dysphagia evaluation scale and Watian water swallow test \\
\hline Notes & In the process of retrieving full-text article \\
\hline
\end{tabular}

\section{Gao 2016}

\begin{tabular}{ll}
\hline Methods & RCT \\
\hline Participants & 90 patients with dysphagia after cerebral infarction \\
\hline Interventions & Chin tuck resistance vs Shaker exercise vs control \\
\hline Outcomes & VFSS, Self-Rating Depression Scale, PAS \\
\hline Notes & In the process of retrieving full-text article \\
\hline
\end{tabular}


Guillen-Sola 2017

\begin{tabular}{ll}
\hline Methods & RCT \\
\hline Participants & $\begin{array}{l}\text { Subacute ischaemic stroke (1 to } 3 \text { weeks) and dysphagia confirmed by videofluoroscopic study } \\
\text { with a score } \geq 3 \text { on the 8-point PAS }\end{array}$ \\
\hline Interventions & Group I: standard swallow therapy \\
& Group II: inspiratory and expiratory muscle training + standard swallow therapy \\
& $\begin{array}{l}\text { Group III: neuromuscular electrical stimulation of suprahyoid muscles, sham inspiratory and expi- } \\
\text { ratory muscle training, and standard swallow therapy }\end{array}$ \\
\hline Outcomes & $\begin{array}{l}\text { Respiratory muscle function (baseline, 3 weeks, and 3 months), severity of dysphagia (PAS) (base- } \\
\text { line and 3 months), and occurrence of respiratory complications (chest x-ray, fever); also vol- } \\
\text { ume-viscosity swallow test (V-VST), Functional Oral Intake Scale, and Dysphagia Outcome and } \\
\text { Severity Scale (baseline, 3 weeks, and 3 months) }\end{array}$ \\
\hline Notes & Study published; in the process of extracting data \\
\hline
\end{tabular}

\section{Hamada 2017}

\begin{tabular}{ll}
\hline Methods & Study design not clear \\
\hline Participants & 56 people with acute stroke and dysphagia \\
\hline Interventions & $\begin{array}{l}\text { General dysphagia therapy vs combination of surface electrical stimulation and general dysphagia } \\
\text { therapy }\end{array}$ \\
\hline Outcomes & Pulmonary infection \\
\hline Notes & In the process of retrieving full-text article \\
\hline
\end{tabular}

Hong 2011

\begin{tabular}{ll}
\hline Methods & RCT \\
\hline Participants & People with cerebral apoplexy and dysphagia \\
\hline Interventions & Strengthened diet nursing vs control \\
\hline Outcomes & Incidence of aspiration, malnutrition, dehydration \\
\hline Notes & In the process of retrieving full-text article \\
\hline
\end{tabular}

\section{Huang 2008}

\begin{tabular}{ll}
\hline Methods & RCT \\
\hline Participants & 66 participants with dysphagia post-ischaemic stroke
\end{tabular}


Huang 2008 (Continued) Interventions
Group 1: electro-acupuncture group

Group 2: rehabilitation training combined with acupoint percutaneous electrical stimulation

Group 3: rehabilitation training combined with acupoint token puncturing

\begin{tabular}{ll}
\hline Outcomes & Quality of life scale specified for dysphagia (name not stated) \\
\hline Notes & In process of retrieving full-text article \\
\hline
\end{tabular}

Huang 2014

\begin{tabular}{ll}
\hline Methods & RCT \\
\hline Participants & People with acute stroke and dysphagia \\
\hline Interventions & Traditional swallowing vs oropharyngeal NMES vs combined NMES/traditional swallowing \\
\hline Outcomes & Swallow score, PAS, VFSS \\
\hline Notes & In process of retrieving relevant outcome data \\
\hline
\end{tabular}

Huimin 2015

\begin{tabular}{ll}
\hline Methods & RCT \\
\hline Participants & 76 people with pharyngeal dysphagia after stroke \\
\hline Interventions & Surface electromyographic biofeedback with conventional therapy vs conventional therapy only \\
\hline Outcomes & $\begin{array}{l}\text { Degree of openness of upper oesophageal sphincter, pharyngeal transit time, maximum displace- } \\
\text { ment of the hyoid bone }\end{array}$ \\
\hline Notes & In the process of retrieving full-text article \\
\hline
\end{tabular}

Jefferson 2008

\begin{tabular}{ll}
\hline Methods & RCT \\
\hline Participants & People with chronic stroke and dysphagia \\
\hline Interventions & $\begin{array}{l}\text { Repetitive transcranial magnetic stimulation vs sham stimulation over the unaffected pharyngeal } \\
\text { motor cortex }\end{array}$ \\
\hline Outcomes & Measurements of cortico-pharyngeal excitability \\
\hline Notes & In the process of retrieving full-text article \\
\hline
\end{tabular}


Ji-Ye 2017

\begin{tabular}{ll}
\hline Methods & RCT \\
\hline Participants & Dysphagia patients with ischaemic stroke and pseudobulbar palsy \\
\hline Interventions & Oral aspirin vs acupuncture (XNJ-Al at Fengchi (GB 20)) with oral aspirin \\
\hline Outcomes & Water-swallowing test, plasma thromboxane B2 and 6-keto-prostaglandin F1a levels \\
\hline Notes & In the process of retrieving full-text article \\
\hline
\end{tabular}

Jia 2006

\begin{tabular}{ll}
\hline Methods & RCT \\
\hline Participants & $\begin{array}{l}40 \text { cases of post-apoplectic dysphagia with } 2 \text { out of } 5 \text { symptoms such as hemiplegia, coma, slurred } \\
\text { speech, unilateral sensory disturbance, dry mouth and tongue, difficulty in swallowing }\end{array}$ \\
\hline Interventions & $\begin{array}{l}\text { Treatment group was treated by acupuncturing points Fengchi (GB 20), Tianzhu (BL 10), Tongli (HT } \\
5), \text { and Lianquan (CV 23) plus rehabilitation exercises } \\
\text { Control group only by rehabilitation exercise }\end{array}$ \\
\hline Outcomes & Therapeutic effect assessed by 1 to 10 point scale \\
\hline Notes & Study published; in the process of extracting data \\
\hline
\end{tabular}

Jiang 2014

\begin{tabular}{ll}
\hline Methods & RCT \\
\hline Participants & People with stroke and dysphagia \\
\hline Interventions & Electroacupuncture group vs VitalStim group vs combined group \\
\hline Outcomes & Water swallow test, swallow score \\
\hline Notes & In the process of retrieving full-text article \\
\hline
\end{tabular}

\section{Jing 2016}

\begin{tabular}{ll}
\hline Methods & RCT \\
\hline Participants & 60 people with dysphagia after stroke \\
\hline Interventions & NMES with conventional therapy vs conventional therapy only \\
\hline Outcomes & $\begin{array}{l}\text { Curative effects, swallowing function, aspiration, laryngeal elevation, food residue, food intake } \\
\text { scores }\end{array}$ \\
\hline Notes & In the process of retrieving full-text article \\
\hline
\end{tabular}


Kim 2017

\begin{tabular}{ll}
\hline Methods & RCT \\
\hline Participants & People with post-stroke oropharyngeal dysphagia confirmed by VFSS \\
\hline Interventions & Tongue-to-palate resistance training vs control \\
\hline Outcomes & Swallowing function - videofluoroscopic dysphagia scale and PAS \\
\hline Notes & Study published; in the process of extracting data \\
\hline
\end{tabular}

\section{Koch 2015}

\begin{tabular}{ll}
\hline Methods & RCT \\
\hline Participants & People with stroke and dysphagia \\
\hline Interventions & Swallowing training using surface electromyography as biofeedback vs standard treatment \\
\hline Outcomes & Swallow score \\
\hline Notes & In the process of retrieving full-text article \\
\hline
\end{tabular}

Konecny 2018

\begin{tabular}{ll}
\hline Methods & RCT \\
\hline Participants & 54 people with early-stage stroke and dysphagia \\
\hline Interventions & Transcutaneous electrical nerve stimulation of suprahyoid muscles vs control \\
\hline Outcomes & Swallow function - videofluoroscopic study, oral transit time, pharyngeal transit time \\
\hline Notes & Study published; in the process of extracting data
\end{tabular}

Koyama 2017

\begin{tabular}{ll}
\hline Methods & RCT \\
\hline Participants & 16 participants with stroke-related dysphagia \\
\hline Interventions & Modified jaw opening exercise vs control \\
\hline Outcomes & $\begin{array}{l}\text { Swallow function - videofluorographic swallowing study, distance between the mental spine and } \\
\text { the hyoid bone, hyoid displacement }\end{array}$ \\
\hline Notes & Study published; in the process of extracting data \\
\hline
\end{tabular}


Lee $2015 b$

\begin{tabular}{ll}
\hline Methods & RCT \\
\hline Participants & 24 people with dysphagia after ischaemic stroke \\
\hline Interventions & $\begin{array}{l}\text { Treatment: } 10 \mathrm{~Hz} \text { rTMS over the brain cortex where motor evoked potential was obtained from the } \\
\text { suprahyoid muscle } \\
\text { Control: } 10 \mathrm{~Hz} \text { rTMS over the brain cortex where motor evoked potential was obtained from the ab- } \\
\text { ductor pollicis brevis muscle }\end{array}$ \\
\hline Outcomes & Functional Dysphagia Scale, PAS, Dysphagia Outcome and Severity Scale \\
\hline Notes & Study published; in the process of extracting data \\
\hline
\end{tabular}

Li 2008

\begin{tabular}{ll}
\hline Methods & RCT \\
\hline Participants & 60 people with ischaemic stroke and dysphagia \\
\hline Interventions & Group 1: acupuncture group and routine treatment and rehabilitation training \\
& Group 2: routine treatment and rehabilitation training \\
\hline Outcomes & Not stated \\
\hline Notes & In the process of retrieving full-text article \\
\hline
\end{tabular}

Li 2009

\begin{tabular}{ll}
\hline Methods & RCT \\
\hline Participants & 60 people post stroke with dysphagia \\
\hline Interventions & Experimental group: acupuncture plus feeding and swallowing rehabilitation training \\
& Control group: swallowing and feeding rehabilitation training \\
\hline Outcomes & Swallowing test \\
\hline Notes & In the process of retrieving full-text article \\
\hline
\end{tabular}

\section{Li 2016}

\begin{tabular}{ll}
\hline Methods & RCT \\
\hline Participants & 60 people with pseudobulbar palsy paralysis dysphagia \\
\hline Interventions & Treatment: 5 needles of the Nape acupuncture
\end{tabular}


Li 2016 (Continued)

Control: routine acupuncture (Lian Quan, Tong Li, Zhao Hai)

\begin{tabular}{ll}
\hline Outcomes & Curative effect dysphagia (unclear) \\
\hline Notes & In the process of retrieving full-text article \\
\hline
\end{tabular}

Liu 2018

\begin{tabular}{ll}
\hline Methods & RCT \\
\hline Participants & 100 people with dysphagia caused by pseudobulbar palsy \\
\hline Interventions & Nape acupuncture with rehabilitative swallowing training vs rehabilitative swallowing training only \\
\hline Outcomes & $\begin{array}{l}\text { Repetitive saliva-swallowing test, water swallow test, standardised swallowing assessment, swal- } \\
\text { low quality-of-life questionnaire (SWAL-QOL) }\end{array}$ \\
\hline Notes & In the process of retrieving full-text article \\
\hline
\end{tabular}

Ma 2016

\begin{tabular}{ll}
\hline Methods & RCT \\
\hline Participants & 80 people with dysphagia and pseudobulbar palsy \\
\hline Interventions & Quick needle insertion at Aqiang point vs routine acupuncture at Lianquan (CV 23) \\
\hline Outcomes & Water swallow test, curative rate \\
\hline Notes & In the process of retrieving full-text article \\
\hline
\end{tabular}

Malik 2017

\begin{tabular}{ll}
\hline Methods & RCT \\
\hline Participants & People with dysphagia (95\% of patients with stroke aetiology) \\
\hline Interventions & Thermal stimulation vs swallowing manoeuvres vs combination of both \\
\hline Outcomes & Function Outcome Swallowing Scale \\
\hline Notes & Study published; in the process of extracting data \\
\hline
\end{tabular}

Mehndiratta 2017

\begin{tabular}{ll}
\hline Methods & RCT \\
\hline Participants & 98 people with dysphagia within the first month after ischaemic stroke \\
\hline
\end{tabular}


Mehndiratta 2017 (Continued)

Interventions Sensory-level electrical stimulation to bilateral masseter muscles vs sham stimulation

\begin{tabular}{ll}
\hline Outcomes & $\begin{array}{l}\text { Bedside Dysphagia Score, Neurological Examination Dysphagia Score, Total Dysphagia Score, } \\
\text { Mann Assessment of Swallowing Ability test, flexible fibreoptic endoscopic evaluation of swallow- } \\
\text { ing }\end{array}$ \\
\hline Notes & Study published; in the process of extracting data \\
\hline
\end{tabular}

\section{Meng 2015}

\begin{tabular}{ll}
\hline Methods & RCT \\
\hline Participants & 251 people with dysphagia after stroke \\
\hline Interventions & Group 1: deep acupuncture with conventional glossopharyngeum acupuncture \\
& Group 2: shallow acupuncture with conventional glossopharyngeum acupuncture \\
& Group 3: conventional glossopharyngeum acupuncture only (control) \\
\hline Outcomes & Water swallowing test evaluation scale \\
\hline Notes & In the process of retrieving full-text article \\
\hline
\end{tabular}

Meng 2018

\begin{tabular}{ll}
\hline Methods & RCT \\
\hline Participants & 30 people with post-stroke dysphagia \\
\hline Interventions & 2 groups given surface NMES at different sites of patients' neck vs control \\
\hline Outcomes & Water swallow test, repetitive saliva swallowing test, dysphagia outcome and severity scale \\
\hline Notes & In the process of retrieving full-text article \\
\hline
\end{tabular}

\section{Moon 2017}

\begin{tabular}{ll}
\hline Methods & RCT \\
\hline Participants & 18 people with stroke and dysphagia \\
\hline Interventions & Expiratory muscle strength training vs control \\
\hline Outcomes & Functional dysphagia scale, PAS, vallecular residue, pyriform sinuses residue \\
\hline Notes & Study published; in the process of extracting data \\
\hline
\end{tabular}


Moon 2018

\begin{tabular}{ll}
\hline Methods & RCT \\
\hline Participants & 16 people with subacute stroke and dysphagia \\
\hline Interventions & Tongue pressure strength and accuracy training vs control \\
\hline Outcomes & $\begin{array}{l}\text { Maximum isometric tongue pressures of the anterior and posterior tongue, Mann Assessment of } \\
\text { Swallowing Ability, Swallowing-Quality of Life }\end{array}$ \\
\hline Notes & In the process of retrieving full-text article \\
\hline
\end{tabular}

\section{NCT00722111}

\begin{tabular}{ll}
\hline Methods & Randomised, open label \\
\hline Participants & 200 people post stroke \\
\hline Interventions & Group 1: lingual press (high-intensity, oral, non-swallowing) \\
& Group 2: effortful swallowing (high-intensity swallowing) \\
& Group 3: natural swallowing (high-frequency, low-intensity swallowing) \\
& Group 4: non-oral sham (control) exercise \\
\hline Outcomes & Composite score of PAS and Residue Scale with no worsening of either at baseline, week 4, and \\
\hline Notes & Study completed; awaiting published data \\
\hline
\end{tabular}

NCT01081444

\begin{tabular}{ll}
\hline Methods & RCT \\
\hline Participants & People with dysphagia and first episode of stroke \\
\hline Interventions & Active vs sham rTMS \\
\hline Outcomes & Videofluoroscopy and high-resolution manometry \\
\hline Notes & Study completed; awaiting published data \\
\hline
\end{tabular}

\section{NCT01085903}

\begin{tabular}{ll}
\hline Methods & Randomised, double-blind (participant, investigator), cross-over assignment \\
\hline Participants & People with stroke, neglect, dysphagia \\
\hline Interventions & Modafinil $200 \mathrm{mg}$ once daily vs placebo for 3 days \\
\hline Outcomes & Predicting response to modafinil among participants with neglect, dysphagia \\
\hline \hline
\end{tabular}


NCT01085903 (Continued)
Notes
Study completed; awaiting published data

NCT01777672

\begin{tabular}{ll}
\hline Methods & RCT \\
\hline Participants & 100 people with oropharyngeal dysphagia due to stroke episode within last 3 months \\
\hline Interventions & Control group: recommendations from patient healthcare providers \\
& $\begin{array}{l}\text { Experimental group 1: oral TRPV1 (natural capsaicin) plus recommendations from patient health- } \\
\text { care providers }\end{array}$ \\
& $\begin{array}{l}\text { Experimental group 2: pharyngeal electrical stimulation plus recommendations from patient } \\
\text { healthcare providers }\end{array}$ \\
& $\begin{array}{l}\text { Experimental group 3: transcutaneous electrical stimulation plus recommendations from patient } \\
\text { healthcare providers }\end{array}$ \\
\hline Vutcomes & force of tongue \\
& $\begin{array}{l}\text { Episodes of aspiration pneumonia and lower respiratory tract infection } \\
\text { Clinical outcomes of nutritional status, complications and clinical symptoms, mortality rates, } \\
\text { cause of death }\end{array}$ \\
\hline Notes & Study completed; awaiting published data \\
\hline
\end{tabular}

\section{NCT02090231}

\begin{tabular}{ll}
\hline Methods & RCT \\
\hline Participants & Post-stroke dysphagia more than 3 months \\
\hline Interventions & Real 5 Hz rTMS vs sham 5 Hz rTMS \\
\hline Outcomes & Dysphagia severity, swallow function \\
\hline Notes & Study completed; awaiting published data \\
\hline
\end{tabular}

\section{NCT02379182}

\begin{tabular}{ll}
\hline Methods & RCT \\
\hline Participants & 90 people with stroke $>3$ months \\
\hline Interventions & Control group: standard clinical care \\
& Sensory group: transcutaneous electrical stimulation at sensory level \\
& Motor group: transcutaneous electrical stimulation at motor level \\
\hline
\end{tabular}


NCT02379182 (Continued)

Outcomes

Notes

PAS; incidence of all adverse events; change in pharyngeal residue prevalence; change in Eating Assessment Tool-10 scores; frequency of chest infection; time from randomisation to death

Study completed; awaiting published data

Nowicki 2003

\begin{tabular}{ll}
\hline Methods & RCT \\
\hline Participants & People with stroke and dysphagia \\
\hline Interventions & Manual + electro-acupuncture (6 to 8 treatments 2 to 3 times per week for 3 weeks) vs control \\
\hline Outcomes & Not available in the study summary \\
\hline Notes & In the process of retrieving full-text article \\
\hline
\end{tabular}

Oshima 2009

\begin{tabular}{ll}
\hline Methods & Unclear design (not stated in abstract) \\
\hline Participants & 218 people with stroke complicated by dysphagia \\
\hline Interventions & Group 1: swallowing training with nutritional and high-risk management \\
& Group 2: control (none of the above) \\
\hline Outcomes & Time taken to oral intake, nutritional status, incidence rate of infection, activities of daily living \\
\hline Notes & In the process of retrieving full-text article \\
\hline
\end{tabular}

\section{Pan 2015}

\begin{tabular}{ll}
\hline Methods & RCT \\
\hline Participants & 70 people with post-stroke dysphagia \\
\hline Interventions & Acupoint massage vs control \\
\hline Outcomes & Improvement rate in swallow function \\
\hline Notes & In the process of retrieving full-text article \\
\hline
\end{tabular}

Park 2017

\begin{tabular}{ll}
\hline Methods & RCT \\
\hline Participants & 40 participants with dysphagia after stroke 6 months $<$ stroke onset \\
\hline
\end{tabular}


Park 2017 (Continued)

Interventions

Group 1: head lift exercise and conventional dysphagia therapy

Group 2: conventional dysphagia therapy

\begin{tabular}{ll}
\hline Outcomes & Movement of hyolaryngeal complex; PAS \\
\hline Notes & Study completed; in the process of retrieving data \\
\hline
\end{tabular}

Park 2018

\begin{tabular}{ll}
\hline Methods & RCT \\
\hline Participants & People with dysphagia following subacute stroke \\
\hline Interventions & Chin tuck against resistance exercise vs control \\
\hline Outcomes & Functional dysphagia scale, PAS \\
\hline Notes & In the process of retrieving full-text article \\
\hline
\end{tabular}

Shao 2017

\begin{tabular}{ll}
\hline Methods & RCT \\
\hline Participants & 64 people with post-stroke upper oesophageal sphincter dystrophy and severe dysphagia \\
\hline Interventions & $\begin{array}{l}\text { Drug therapy and conventional swallowing rehabilitation training vs columnar balloon dilatation } \\
\text { combined with drug therapy and conventional swallowing rehabilitation training }\end{array}$ \\
\hline Outcomes & Upper sphincter dynamics and dysphagia scores \\
\hline Notes & In the process of retrieving full-text article \\
\hline
\end{tabular}

Su 2010

\begin{tabular}{ll}
\hline Methods & RCT \\
\hline Participants & 60 people with dysphagia after stroke \\
\hline Interventions & Group 1: electroacupuncture \\
& Group 2: swallowing training \\
\hline Outcomes & VFSS and Kubota water swallowing function test \\
\hline Notes & In the process of retrieving full-text article \\
\hline
\end{tabular}


Sun 2008

\begin{tabular}{ll}
\hline Methods & RCT \\
\hline Participants & People with dysphagia after stroke \\
\hline Interventions & Acupuncture at Lianquan, Yamen, and Tian Zhu acupoints vs VitalStim therapy \\
\hline Outcomes & Swallowing function \\
\hline Notes & In the process of retrieving full-text article \\
\hline
\end{tabular}

Sun 2018

\begin{tabular}{ll}
\hline Methods & RCT \\
\hline Participants & People with stroke and dysphagia \\
\hline Interventions & $\begin{array}{l}\text { Treatment group treated by intradermal needle-embedding at Lianquan (CV 23), Jialian- } \\
\text { quan-point, Yifeng (TE 17), Ashi-point, etc. (once every other day for 20 days) on the basis of treat- } \\
\text { ments used in the control group } \\
\text { Control group was treated with conventional medicines, NMES of the bilateral midlines of the neck, } \\
\text { and swallowing function training }\end{array}$ \\
\hline Outcomes & Swallowing function (0 to 10 point scaling), surface electromyography \\
\hline Notes & Study published; in the process of extracting data \\
\hline
\end{tabular}

\section{Suntrup-Krueger 2018}

\begin{tabular}{ll}
\hline Methods & RCT \\
\hline Participants & People with dysphagia due to stroke \\
\hline Interventions & Experimental group: transcranial direct current stimulation vs sham group: sham stimulation \\
\hline Outcomes & $\begin{array}{l}\text { Fibreoptic Endoscopic Dysphagia Severity Scale, diet at discharge, dysphagia severity rating score, } \\
\text { endoscopically assessed swallow function }\end{array}$ \\
\hline Notes & Study completed; in the process of retrieving data \\
\hline
\end{tabular}

Tageldin 2017

\begin{tabular}{ll}
\hline Methods & RCT \\
\hline Participants & 30 people with dysphagia following brain stem infarction \\
\hline Interventions & rTMS vs sham rTMS on bilateral supratentorial motor area \\
\hline Outcomes & Modified dysphagia outcome and severity scale \\
\hline
\end{tabular}


Tageldin 2017 (Continued)
Notes
Study completed; awaiting full published data

Umay 2017

\begin{tabular}{ll}
\hline Methods & RCT \\
\hline Participants & 98 people with dysphagia within the first month after ischaemic stroke \\
\hline Interventions & $\begin{array}{l}\text { Sensory-level electrical stimulation vs sham sensory-level electrical stimulation to bilateral mas- } \\
\text { seter muscles }\end{array}$ \\
\hline Outcomes & $\begin{array}{l}\text { Bedside Dysphagia Score, Neurological Examination Dysphagia Score, Total Dysphagia Score, and } \\
\text { Mann Assessment of Swallowing Ability test, flexible fibreoptic endoscopic evaluation of swallow- } \\
\text { ing }\end{array}$ \\
\hline Notes & Study published; in the process of extracting data \\
\hline
\end{tabular}

\section{Wang 2010}

\begin{tabular}{ll}
\hline Methods & RCT \\
\hline Participants & 84 people with cerebral stroke and dysphagia \\
\hline Interventions & Group 1: routine therapy and acupuncture \\
& Group 2: routine therapy \\
\hline Outcomes & Not stated \\
\hline Notes & In the process of retrieving full-text article \\
\hline
\end{tabular}

\section{Wang 2014}

\begin{tabular}{ll}
\hline Methods & RCT \\
\hline Participants & 54 nasal feeding patients with pseudobulbar palsy or bulbar palsy after acute ischaemic stroke \\
\hline Interventions & Integrated swallowing function rehabilitation training vs routine treatment \\
\hline Outcomes & Swallow score, oral intake function \\
\hline Notes & In the process of retrieving full-text article \\
\hline
\end{tabular}

Wang 2015

\begin{tabular}{ll}
\hline Methods & RCT \\
\hline Participants & 91 people with post-stroke deglutition disorders \\
\hline
\end{tabular}


Wang 2015 (Continued)

Interventions Acupuncture using the Tong Guan Li Qiao needling method vs control

\begin{tabular}{ll}
\hline Outcomes & $\begin{array}{l}\text { Standard Swallowing Assessment (Modified Barthel Index), Swallowing-related Quality of Life, } \\
\text { Hamilton Depression Scale }\end{array}$ \\
\hline Notes & In the process of retrieving full-text article \\
\hline
\end{tabular}

Wang 2017

\begin{tabular}{ll}
\hline Methods & RCT \\
\hline Participants & 96 people with dysphagic stroke \\
\hline Interventions & Observation group to receive Rood intervention; control group to receive routine oral intervention \\
\hline Outcomes & Swallowing function, nutritional status and interventional effect - no further details \\
\hline Notes & Study published; in the process of extracting data \\
\hline
\end{tabular}

\section{Wei 2017}

\begin{tabular}{ll}
\hline Methods & RCT \\
\hline Participants & 30 people with upper oesophageal sphincter dysfunction due to unilateral brainstem stroke \\
\hline Interventions & Modified balloon dilatation therapy vs control \\
\hline Outcomes & $\begin{array}{l}\text { Amplitude of bilateral submental motor evoked potentials induced by transcranial magnetic stim- } \\
\text { ulations over bilateral motor cortex, diameters of upper oesophageal sphincter opening, maximal } \\
\text { displacement of hyoid }\end{array}$ \\
\hline Notes & Study published; in the process of extracting data \\
\hline
\end{tabular}

\section{Wu 2011}

\begin{tabular}{ll}
\hline Methods & RCT \\
\hline Participants & 229 people with dysphagia after stroke \\
\hline Interventions & Group 1: acupuncture \\
& Group 2: acupuncture and rehabilitation training \\
& Group 3: control group with rehabilitation training \\
\hline Outcomes & Traditional Chinese medicine swallowing assessment, swallowing test, Swallowing Quality of Life \\
\hline Scale - SWAL-QOL \\
\hline In the process of retrieving full-text article
\end{tabular}


Wu 2013

\begin{tabular}{ll}
\hline Methods & RCT \\
\hline Participants & 90 people with dysphagia after stroke \\
\hline Interventions & Group 1: routine acupuncture group + routine treatment and swallowing training \\
& $\begin{array}{l}\text { Group 2: acupuncture kinesitherapy simultaneously at ezhongxian, lianquan (RN23), jialianquan } \\
\text { points + routine treatment, and swallowing training }\end{array}$ \\
& Group 3: routine treatment and swallowing training \\
\hline Outcomes & Water drinking test and brainstem auditory evoked potential \\
\hline Notes & In the process of retrieving full-text article \\
\hline
\end{tabular}

Xia 2010

\begin{tabular}{ll}
\hline Methods & RCT \\
\hline Participants & 120 people with dysphagia after stroke \\
\hline Interventions & Experimental group: feeding-swallowing training and acupuncture treatment \\
& Control group: feeding-swallowing training \\
\hline Outcomes & Standardised Swallowing Assessment, VFSS, Modified Barthel Index, Swallowing Quality of LIfe \\
\hline Scale - SWAL-QOL
\end{tabular}

Xie 2011

\begin{tabular}{ll}
\hline Methods & RCT \\
\hline Participants & 148 people with stroke and dysphagia \\
\hline Interventions & $\begin{array}{l}\text { Acupuncture group (body acupuncture, electrical acupuncture, and scalp acupuncture) vs rehabili- } \\
\text { tation group }\end{array}$ \\
\hline Outcomes & $\begin{array}{l}\text { Intention-to-treat analysis and on-treatment/per-protocol analysis, Watian swallowing ability, pul- } \\
\text { monary infection rate, mortality }\end{array}$ \\
\hline Notes & In the process of retrieving full-text article \\
\hline
\end{tabular}

Xu 2013

\begin{tabular}{ll}
\hline Methods & RCT \\
\hline Participants & 140 people with stroke \\
\hline
\end{tabular}


Xu 2013 (Continued)

Interventions Experimental group: acupuncture and Western medicine

Control group: Western medicine

\begin{tabular}{ll}
\hline Outcomes & Water drinking test \\
\hline Notes & In the process of retrieving full-text article \\
\hline
\end{tabular}

Xue 2004

\begin{tabular}{ll}
\hline Methods & RCT \\
\hline Participants & People with post-stroke dysphagia \\
\hline Interventions & Early rehabilitation + acupuncture vs control \\
\hline Outcomes & Not available in the study summary \\
\hline Notes & In the process of retrieving full-text article \\
\hline
\end{tabular}

\begin{tabular}{ll} 
Yang 2008 & RCT \\
\hline Methods & People with post-stroke dysphagia \\
\hline Participants & $\begin{array}{l}\text { Functional electrical stimulation } 40 \text { minutes/d vs functional electrical stimulation } 40 \text { minutes twice } \\
\text { daily }\end{array}$ \\
\hline Interventions & Swallowing function \\
\hline Outcomes & In the process of retrieving full-text article \\
\hline Notes &
\end{tabular}

\begin{tabular}{ll}
\hline Yang 2012 & RCT \\
\hline Methods & People with post-stroke dysphagia diagnosed using VFSS \\
\hline Interventions & Anodal tDCS group (1 mA for 20 minutes) vs sham group (1 mA for 30 seconds) \\
\hline Outcomes & Functional dysphagia scale \\
\hline Notes & In the process of retrieving full-text article \\
\hline
\end{tabular}

\section{Zeng 2017}

Methods

$$
\mathrm{RCT}
$$


Zeng 2017 (Continued)
Participants
112 people with cerebral infarction and dysphagia

\begin{tabular}{ll}
\hline Interventions & NMES vs control \\
\hline Outcomes & Water-drinking test, Hamilton Anxiety Scale test, Hamilton Depression Scale \\
\hline Notes & In the process of retrieving full-text article \\
\hline
\end{tabular}

\section{Zhang 2007}

\begin{tabular}{ll} 
Methods & RCT \\
\hline Participants & People with stroke, dysphagia, and poor elevation of the larynx \\
\hline Interventions & Comparison of 2 methods of larynx elevation ( 15 minutes, $5 \times$ day for 4 weeks) \\
\hline Outcomes & Not available in the study summary \\
\hline Notes & In the process of retrieving full-text article \\
\hline
\end{tabular}

\section{Zhang 2015}

\begin{tabular}{ll}
\hline Methods & RCT \\
\hline Participants & 198 people with dysphagia after stroke \\
\hline Interventions & Huoshe Liyan Decoction vs control \\
\hline Outcomes & Efficacy rate, swallow function (unclear) \\
\hline Notes & In the process of retrieving full-text article \\
\hline
\end{tabular}

Zhang 2016

\begin{tabular}{ll}
\hline Methods & RCT \\
\hline Participants & People with dysphagia with medullary infarction \\
\hline Interventions & $\begin{array}{l}\text { Traditional swallowing therapy vs sensory approach combined with traditional swallowing therapy } \\
\text { vs motor approach combined with traditional swallowing therapy }\end{array}$ \\
\hline Outcomes & Swallow function, quality of life, cognition \\
\hline Notes & In the process of retrieving relevant data \\
\hline
\end{tabular}

\section{Zhang 2017}

Methods RCT


Zhang 2017 (Continued)

\begin{tabular}{ll} 
Participants & 80 people with stroke and dysphagia \\
\hline Interventions & $\begin{array}{l}\text { Vitalstim Electroacupuncture of Fengchi (GB 20), Jinjin (EX-HN 12) and Yuye (EX-HN 13) with a Vital- } \\
\text { stim Electrostimulator, and manual acupuncture stimulation of Lianquan (CV 23), Tiantu (CV 22) vs } \\
\text { control. Both groups received conventional therapy }\end{array}$ \\
\hline Outcomes & $\begin{array}{l}\text { Kubota swallowing ability test, dysphagia subscale (0 to } 6 \text { scores) of the neurological deficit de- } \\
\text { grees, videofluorography assessment, Medical Outcomes Study Item Short Form Health Survey } \\
\text { (SF-36) }\end{array}$ \\
\hline Notes & In the process of retrieving full-text article
\end{tabular}

Zhen 2014

\begin{tabular}{ll}
\hline Methods & RCT \\
\hline Participants & 97 people with post-stroke deglutition dysfunction \\
\hline Interventions & Group A: acupuncture with conventional treatment \\
& Group B: VitalStim electric stimulation with conventional treatment \\
& Group C: conventional treatment only \\
\hline Outcomes & Swallow function (water-drinking test, stethocatharsis scoring, and fluoroscopic examination) \\
\hline Notes & In the process of retrieving full-text article \\
\hline
\end{tabular}

\begin{tabular}{ll}
\hline Zhong 2003 & RCT \\
\hline Methods & People with stroke and dysphagia 15 to 40 days post stroke \\
\hline Interventions & Head acupuncture vs body acupuncture vs control \\
\hline Outcomes & Not available in the study summary \\
\hline Notes & In the process of retrieving full-text article \\
\hline
\end{tabular}

\begin{tabular}{ll} 
Zhu 2015a & RCT \\
\hline Methods & People with dysphagia after stroke \\
\hline Participants & $\begin{array}{l}\text { Conventional training vs surface electromyographic biofeedback treatment with conventional } \\
\text { training }\end{array}$ \\
\hline Interventions & Upper oesophageal sphincter opening, pharyngeal transit time \\
\hline Outcomes &
\end{tabular}


Zhu 2015a (Continued)
Notes
In the process of retrieving full-text article

Zhu 2015b

\begin{tabular}{ll}
\hline Methods & RCT \\
\hline Participants & 68 people with dysphagia after ischaemic stroke \\
\hline Interventions & $\begin{array}{l}\text { Combined treatment group }(\mathrm{n}=34) \text { receiving swallowing training, feeding strategies, and low-fre- } \\
\text { quency electrical stimulation } \\
\text { Control group }(\mathrm{n}=34) \text { receiving swallowing training and feeding strategies }\end{array}$ \\
\hline Outcomes & VFSS, Standardized Swallowing Assessment \\
\hline Notes & Study published; in the process of extracting data
\end{tabular}

ASHA-NOMS: American Speech-Language-Hearing Association National Outcomes Measurement System

EEG: electroencephalography

Hz: Hertz

NIHSS: National Institutes of Health Stroke Scale

NMES: neuromuscular electrical stimulation

PAS: Penetration Aspiration Scale

$\mathrm{RCT}$ : randomised controlled trial

rTMS: repetitive transcranial magnetic stimulation

SWAL-QOL: Swallowing Quality of Life Questionnaire

tDCS: transcranial direct current stimulation

TRPV1: transient receptor potential vanilloid 1

VFSS: videofluoroscopic swallow study

V-VST: volume-viscosity swallow test

Characteristics of ongoing studies [ordered by study ID]

\section{ChiCTR-ICR-15006004}

\begin{tabular}{ll}
\hline Trial name or title & Clinical observation of YiShen-TongQiao acupuncture on pharyngeal dysphagia after stroke \\
\hline Methods & RCT \\
\hline Participants & 90 stroke patients with pharyngeal dysphagia \\
\hline Interventions & Observational group: YiShen-TongQiao acupuncture treatment \\
\hline Control group: rehabilitation training \\
\hline Starting date & Kubota drinking water test score; Swallow Quality of Life \\
\hline Contact information & 2015 \\
\hline Notes & $\begin{array}{l}\text { Fu Chuan; yuchuan106@126.com } \\
\text { tional Chinese Medicine }\end{array}$ \\
\hline
\end{tabular}


ChicTR-IOR-17010505

\begin{tabular}{ll}
\hline Trial name or title & $\begin{array}{l}\text { Fire N needle for patients with dysphagia caused by post-stroke pseudobulbar palsy: a randomized } \\
\text { controlled clinical trial }\end{array}$ \\
\hline Methods & Randomised, parallel controlled trial \\
\hline Participants & 64 participants with dysphagia after stroke, 30 to 75 years old, onset time $<8$ months \\
\hline Interventions & Group A: fire needle \\
& Group B: rehabilitation treatment of dysphagia \\
\hline Outcomes & $\begin{array}{l}\text { Watian water test evaluation, TengShi swallowing disorder evaluation, swallowing-related quality } \\
\text { of life, dysphagia assessment scale of Traditional Chinese Medicine, pulse oximetry }\end{array}$ \\
\hline Starting date & 2017, but not yet recruiting \\
\hline Contact information & Xiaolu Qian; qian_xiaolu@163.com \\
\hline Notes & Funding: Shanghai Municipal Commission of Health and Family Planning \\
\hline
\end{tabular}

\section{ChicTR-IOR-17011359}

Trial name or title

The study on the effect of electroacupuncture at Lianquan and Fengfu on one side of brain swallowing function

\begin{tabular}{ll}
\hline Methods & Randomised parallel controlled trial \\
\hline Participants & 30 participants aged 18 to 65 years; inclusion criteria not clear \\
\hline Interventions & Electroacupuncture group \\
& Sham acupuncture group \\
\hline Outcomes & MEP of mylohyoid muscle \\
\hline Starting date & Resting motion threshold of mylohyoid muscle \\
\hline Contact information & 2017 \\
\hline Notes & Lin Wang; 373670740@qq.com \\
\hline
\end{tabular}

\section{ChiCTR-IPC-14005435}

\begin{tabular}{ll}
\hline Trial name or title & $\begin{array}{l}\text { Research on mechanism of central regulation of transcranial magnetic stimulation on post-stroke } \\
\text { dysphagia patients }\end{array}$ \\
\hline Methods & Randomised parallel controlled trial, phase 1 \\
\hline Participants & 20 virtual lesion group; 20 stroke patient group; 20 control \\
\hline Interventions & Virtual lesion group: continuous theta burst stimulation \\
\hline
\end{tabular}


ChiCTR-IPC-14005435 (Continued)

Patient group: transcranial magnetic stimulation

Control: conventional treatments

\begin{tabular}{ll}
\hline Outcomes & $\begin{array}{l}\text { MEP; pharyngeal pressure waveform; upper oesophageal sphincter pressure waveform; centre net- } \\
\text { work of swallowing }\end{array}$ \\
\hline Starting date & 2013 \\
\hline Contact information & Yue Lan; bluemooning@163.com \\
\hline Notes & Funding: National Science Foundation of China \\
\hline
\end{tabular}

\section{ChicTR-ROC-17011673}

Trial name or title Neuromodulation on post-stroke patients: a clinical control trial based on mapping swallowing
musculature motor cortex

\begin{tabular}{ll}
\hline Methods & Clinical control (randomisation unclear) \\
\hline Participants & 120 participants with dysphagia post stroke \\
\hline Interventions & $\begin{array}{l}\text { Experimental group: TMS } \\
\text { Control group: sham TMS }\end{array}$ \\
\hline Outcomes & Pharyngeal musculature MEP; MEP amplitude; latency of MEP; hotspot \\
\hline Starting date & 2017 \\
\hline Contact information & Wanqi Li; $1170782244 @ q q . c 0 m$ \\
\hline Notes & Funding: - \\
\hline
\end{tabular}

\section{ChiCTR1800014337} $\begin{array}{ll}\text { Trial name or title } & \text { High frequency repetitive transcranial magnetic stimulation in the rehabilitation of post-stroke } \\ \text { swallowing disorder }\end{array}$

\begin{tabular}{ll}
\hline Methods & Randomised parallel controlled trial \\
\hline Participants & 40 participants with acute stroke ( $>2$ weeks post onset) with dysphagia \\
\hline Interventions & High-frequency rTMS + routine swallow training vs routine swallow training alone \\
\hline Outcomes & $\begin{array}{l}\text { Surface EMG; VFSS; Standardised Swallowing Study; VGF (no explanation provided on website); } \\
\text { PAS; water drinking test scale for depression }\end{array}$ \\
\hline Starting date & 2018 \\
\hline Contact information & Zhu Qixiu; szjzqxsx@163.com \\
\hline Notes & Funding: Shandong Province Science and Technology Plan \\
\hline
\end{tabular}


ChiCTR1800015837

\section{Trial name or title}

\section{Trial name or title}

\begin{tabular}{ll}
\hline Methods & Randomised parallel controlled trial \\
\hline Participants & 242 stroke patients with dysphagia from 2 weeks to 6 months \\
\hline Interventions & Treatment: acupuncture treatment based on surface electromyography \\
& Control: traditional acupuncture treatment \\
\hline Outcomes & $\begin{array}{l}\text { Water swallow test rating scale of depression, Standardized Swallowing Assessment, videofluoro- } \\
\text { scopic swallowing study }\end{array}$ \\
\hline Starting date & 2016 \\
\hline Contact information & Guoping Zhou; doctorzgp@sina.com \\
\hline Notes & Funding: Construction of High-level University Scientific Research Funding \\
\hline
\end{tabular}

\section{ISRCTN14124645}

\begin{tabular}{ll}
\hline Trial name or title & $\begin{array}{l}\text { Metoclopramide and selective oral decontamination for avoiding pneumonia after stroke (MAPS-2) } \\
\text { Trial }\end{array}$ \\
\hline Methods & Acute stroke within 9 hours of clinical onset \\
\hline Participants & $\begin{array}{l}\text { Metoclopramide and placebo paste } \\
\text { Metoclopramide and antibiotic paste } \\
\text { Interventions }\end{array}$ \\
$\begin{array}{l}\text { Placebo metoclopramide and antibiotic paste } \\
\text { Placebo metoclopramide and placebo paste }\end{array}$ \\
$\begin{array}{l}\text { Mortality up to the end of the study (90 days), pneumonia within 14 days, number of days of an- } \\
\text { tibiotic treatment for pneumonia within the first 30 days, neurological recovery (NIHSS), disability } \\
\text { (mRS), quality of life (EuroQol) }\end{array}$ \\
\hline Starting date & $\begin{array}{l}\text { 1 January } 2017 \\
\text { Contact information }\end{array}$ \\
\hline Centre, Thornburrow Drive, Hartshill ST4 7QB, Stoke-on-Trent, United Kingdom
\end{tabular}

\section{ISRCTN68981054}

Trial name or title

Treatment of dysphagia after stroke with He's santong needling method: a prospective randomized controlled study

Methods RCT


ISRCTN68981054 (Continued)

Participants $\quad 60$ stroke patients with oral and pharyngeal dysphagia

Interventions

Experimental group: He's santong needling method acupuncture combined with swallowing rehabilitation

Control group: swallowing rehabilitation

\begin{tabular}{ll}
\hline Outcomes & $\begin{array}{l}\text { Dynamics of swallowing function measured using FEES and Caiteng 7 Rank } \\
\text { Swallowing Quality of Life - SWAL-QOL, Modified MASA, surface EMG }\end{array}$ \\
\hline Starting date & 2017 \\
\hline Contact information & Bin Li; libin@bjzhongyi.com \\
\hline Notes & Funding: Beijing Traditional Chinese Medicine Administration Administrative Project \\
\hline
\end{tabular}

\section{NCT01758991}

Trial name or title

Therapeutic Impact of tDCS on dysphagia in the acute phase of stroke (improving swallowing after stroke with transcranial direct current stimulation (iSWAT))

\begin{tabular}{ll}
\hline Methods & RCT \\
\hline Participants & 100 acute stroke patients with dysphagia \\
\hline Interventions & Experimental group: tDCS \\
& Control group: sham tDCS \\
\hline Outcomes & Videofluoroscopy; fiberoptic endoscopic evaluation of swallowing; NIHSS; clinical records; swal- \\
\hline lowing quality of life - SWAL-QOL \\
\hline Contact information & 2013 \\
\hline Notes & Katalin de Fays; katalin.defays@uclouvain.be \\
\hline
\end{tabular}

\section{NCT01919112}

\begin{tabular}{ll}
\hline Trial name or title & Non-invasive brain stimulation for swallowing recovery after a dysphagic stroke \\
\hline Methods & RCT \\
\hline Participants & Moderate to severe dysphagic patients with acute stroke documented by imaging \\
\hline Interventions & High dose vs low dose vs sham (control) anodal tDCS \\
\hline Outcomes & Improvement in swallowing \\
\hline Starting date & 2013 \\
\hline
\end{tabular}


NCT01919112 (Continued)

Contact information

Sandeep Kumar; Beth Israel Deaconess Medical Center; 617-632-8917; skumar@bidmc.harvard.edu

Notes $\quad$ Funding: Beth Israel Deaconess Medical Center

\section{NCT02322411}

Trial name or title

Effects of device-facilitated isometric progressive resistance oropharyngeal (I-PRO) therapy on dysphagia related outcomes in patients post-stroke

\begin{tabular}{ll}
\hline Methods & Randomised controlled pilot study \\
\hline Participants & 30 ischaemic stroke patients within 6 months of acute stroke diagnosis \\
\hline Interventions & $\begin{array}{l}\text { Group 1: } 12 \text { weeks of Isometric Progressive Resistance Oropharyngeal Therapy plus compensatory } \\
\text { treatment }\end{array}$ \\
Group 2: compensatory treatment only
\end{tabular}

\begin{tabular}{ll}
\hline Outcomes & Change in maximum isometric tongue pressures; bolus flow durational measures; swallowing-re- \\
lated pressures; swallowing quality of life - SWAL-QOL; functional oral intake scale; pneumonia di- \\
agnoses; hospital admissions
\end{tabular}

Starting date 2014

\begin{tabular}{ll}
\hline Contact information & Nicole Pulia; nicolepulia@gmail.com \\
\hline Notes & Sponsors and collaborators: University of Wisconsin, Madison \\
\hline
\end{tabular}

\section{NCT02470078}

\begin{tabular}{ll}
\hline Trial name or title & $\begin{array}{l}\text { Randomised controlled trial of pharyngeal electrical stimulation for the treatment of post-extuba- } \\
\text { tion dysphagia in acute stroke patients }\end{array}$ \\
\hline Methods & Randomised parallel assignment trial \\
\hline Participants & 60 stroke patients with severe dysphagia post extubation due to acute stroke \\
\hline Interventions & Pharyngeal electrical stimulation vs sham stimulation \\
\hline Outcomes & $\begin{array}{l}\text { Pneumonia rate; reintubation rate; length of stay; PEG tube placement; swallowing function; time } \\
\text { until oral nutrition }\end{array}$ \\
\hline Starting date & 2015 \\
\hline Contact information & Rainer Dziewas; dziewas@uni-muenster.de \\
\hline Notes & Funding: University Hospital Muenster \\
\hline
\end{tabular}


NCT02576470

\begin{tabular}{|c|c|}
\hline Trial name or title & Motor learning in dysphagia rehabilitation \\
\hline Methods & Randomised, parallel assignment trial \\
\hline Participants & 21 to 100 years with a swallowing problem \\
\hline \multirow[t]{13}{*}{ Interventions } & $\begin{array}{l}\text { Investigating } 3 \text { forms of biofeedback for training swallowing manoeuvres or compensatory tech- } \\
\text { niques and pairing with adjuvant techniques - tDCS, TMS, and financial reward. }\end{array}$ \\
\hline & Group 1: VFSS biofeedback \\
\hline & Group 2: submental EMG biofeedback \\
\hline & Group 3: mixed VFSS and submental EMG biofeedback \\
\hline & Group 4: VFSS biofeedback with anodal tDCS and TMS \\
\hline & Group 5: submental EMG biofeedback with anodal tDCS and TMS \\
\hline & Group 6: mixed VFSS, submental EMG with anodal tDCS and TMS. \\
\hline & Group 7: VFSS with sham tDCS \\
\hline & Group 8: submental EMG with sham tDCS \\
\hline & Group 9: mixed VFSS and submental EMG with sham tDCS \\
\hline & Group 10: VFSS with financial reward \\
\hline & Group 11: submental EMG with financial reward \\
\hline & Group 12: mixed VFSS and submental EMG with financial reward \\
\hline Outcomes & $\begin{array}{l}\text { PAS, targeted dysphagia training biofeedback using VFSS images, submental EMG measures and } \\
\text { both VFSS and submental EMG measures; dysphagia manoeuvres, kinematic analysis, financial re- } \\
\text { ward analysis }\end{array}$ \\
\hline \multicolumn{2}{|l|}{ Starting date } \\
\hline \multicolumn{2}{|l|}{ Contact information } \\
\hline Notes & Study completed; awaiting full published data \\
\hline \multicolumn{2}{|l|}{ NCT02960737 } \\
\hline Trial name or title & $\begin{array}{l}\text { Dysphagia evaluation after stroke-incidence and effect of oral screen intervention on swallowing } \\
\text { dysfunction (DESIRE) }\end{array}$ \\
\hline Methods & Interventional, randomised, parallel assignment. Double-blind (investigator, outcomes assessor) \\
\hline Participants & Acute stroke patients $6( \pm 2)$ weeks after first-time transient ischaemic attack and stroke \\
\hline \multirow[t]{2}{*}{ Interventions } & $\begin{array}{l}\text { Experimental group: intensive training with oral screen and traditional compensatory swallowing } \\
\text { training }\end{array}$ \\
\hline & Control group: no intervention; traditional compensatory swallowing training only \\
\hline
\end{tabular}


NCT02960737 (Continued)

Outcomes

Swallowing ability, swallowing function, lip force, swallowing quality of life, dysarthria, oral health, activities of daily living, global disability, NIHSS

\begin{tabular}{ll}
\hline Starting date & 2016 \\
\hline Contact information & Patricia Hägglund, PhD Student; +46907850000; patricia.hagglund@umu.se \\
\hline Notes & Sponsor: Umeå University \\
\hline
\end{tabular}

NCT03021252

\begin{tabular}{ll}
\hline Trial name or title & $\begin{array}{l}\text { The RETORNUS-2 study: impact of respiratory muscle training on swallowing disorders in stroke } \\
\text { patients }\end{array}$ \\
\hline Methods & Interventional, randomised, parallel assignment; single-blind (outcomes assessor) \\
\hline Participants & Stroke onset 1 month \\
\hline Interventions & $\begin{array}{l}\text { Experimental group: high-intensity inspiratory and expiratory muscle training (IEMT) (IEMT + stan- } \\
\text { dard swallow therapy) vs control } \\
\text { Sham IEMT } \\
\text { Sham IEMT + standard swallow therapy }\end{array}$ \\
\hline Outcomes & Change in dysphagia severity, change in respiratory muscle strength \\
\hline Starting date & 2017 \\
\hline Contact information & Anna Guillen-Sola; aguillen@parcdesalutmar.cat \\
\hline Notes & Funding: Parc de Salut Mar \\
\hline
\end{tabular}

\section{NCT03247374}

\begin{tabular}{ll}
\hline Trial name or title & $\begin{array}{l}\text { Bio-feedback treatment versus standard treatment for dysphagic post-stroke patients: a random- } \\
\text { ized controlled trial }\end{array}$ \\
\hline Methods & RCT \\
\hline Participants & 40 patients ( $>6$ weeks onset) with post-stroke dysphagia \\
\hline Interventions & Experimental group: biofeedback (visual and verbal feedback) \\
\hline Cutcomes & Fontrol group: standard SLT (verbal feedback) \\
\hline Starting date & 2017 \\
\hline Contact information & Sara Nordio; sara.nordio@ospedalesancamillo.net \\
\hline Notes & Funding: IRCCS San Camillo, Venezia, Italy \\
\hline
\end{tabular}


NCT03274947

Trial name or title

The utility of cerebellar transcranial magnetic stimulation in the neurorehabilitation of dysphagia after stroke

\begin{tabular}{|c|c|}
\hline Methods & $\mathrm{RCT}$ \\
\hline Participants & 72 participants with post-stroke dysphagia within 6 weeks of symptom onset \\
\hline \multirow[t]{7}{*}{ Interventions } & Protocol 1 \\
\hline & Experimental group: cerebellar TMS \\
\hline & Control group: sham TMS \\
\hline & Protocol 2 \\
\hline & $\begin{array}{l}\text { Experimental group: low-level cerebellar TMS stimulation (once per day for } 3 \text { days) plus standard } \\
\text { SLT }\end{array}$ \\
\hline & $\begin{array}{l}\text { Experimental group: high-level cerebellar TMS stimulation (twice per day for } 5 \text { days) plus standard } \\
\text { SLT }\end{array}$ \\
\hline & Control group: sham stimulation (twice per day for 5 days) plus standard SLT \\
\hline \multirow[t]{2}{*}{ Outcomes } & Protocol 1: videofluoroscopy before and at 1 hour \\
\hline & $\begin{array}{l}\text { Protocol 2: videofluoroscopy; functional oral intake scale; dysphagia severity rating scale; feeding } \\
\text { status; mRS }\end{array}$ \\
\hline Starting date & 2017 \\
\hline Contact information & Shaheen Hamdy; shaheen.hamdy@manchester.ac.uk \\
\hline Notes & Funding: University of Manchester, Medical Research Council University of Nottingham \\
\hline
\end{tabular}

NCT03358810

\begin{tabular}{ll}
\hline Trial name or title & Pharyngeal electrical stimulation evaluation for dysphagia after stroke \\
\hline Methods & RCT \\
\hline Participants & 270 acute ischaemic or hemorrhagic cerebral stroke within 7 to 28 days of baseline VFSS \\
\hline Interventions & Experimental group: pharyngeal electrical stimulation \\
& Control group: sham pharyngeal electrical stimulation \\
\hline Outcomes & PAS (based on VFSS); time to removal of NG/PEG tube/transition to oral feeding or first diet up- \\
\hline grarting date & 2017 functional oral intake scale \\
\hline Contact information & Phagenesis Ltd. \\
\hline Notes & Funding: Phagenesis Ltd.; Regulatory and Clinical Research Institute; Cytel \\
\hline
\end{tabular}


NCT03499574

\begin{tabular}{ll}
\hline Trial name or title & $\begin{array}{l}\text { A randomized controlled feasibility trial of dysphagia therapy using biofeedback in patients with } \\
\text { acute stroke }\end{array}$ \\
\hline Methods & RCT \\
\hline Participants & Participants with new diagnosis of acute stroke and dysphagia \\
\hline Interventions & Control: usual care only \\
\hline Outcomes & $\begin{array}{l}\text { Dysphagia Severity Rating Scale, Functional Oral Intake Scale, PAS, Dysphagia Handicap Index, } \\
\text { modified Rankin Scale, NIHSS, mortality, incidence of pneumonia }\end{array}$ \\
\hline Starting date & 2018 \\
\hline Contact information & Timothy England; timothy.england@nottingham.ac.uk \\
\hline Notes & Funding: University of Nottingham \\
\hline
\end{tabular}

PACTR201710002724163

\begin{tabular}{ll}
\hline Trial name or title & $\begin{array}{l}\text { Effect of transcutaneous electrical nerve stimulation and conventional therapy in post-stroke dys- } \\
\text { phagic patients: a randomized controlled trial }\end{array}$ \\
\hline Methods & RCT \\
\hline Participants & Dysphagic patients following ischaemic stroke less than 1 month (aged 45 to 70 years) \\
\hline Interventions & TENS vs TENS + conventional treatment vs conventional treatment \\
\hline Outcomes & Swallow function \\
\hline Starting date & 2017 \\
\hline Contact information & Rami Maged; ramimaged@hotmail.com \\
\hline Notes & Funding: Taheal Rehabilitation Centre \\
\hline
\end{tabular}

U1111-1188-0335

\begin{tabular}{ll}
\hline Trial name or title & Program of rehabilitation with therapeutic efficacy control in oropharyngeal dysphagia after stroke \\
\hline Methods & Randomised, parallel trial \\
\hline Participants & 20 participants with dysphagia after stroke \\
\hline Interventions & $\begin{array}{l}\text { Group 1: neuromuscular electrical stimulation associated with sour taste swallowing and cold tem- } \\
\text { perature }\end{array}$ \\
& Group 2: stimulation of swallowing sour taste and cold temperature
\end{tabular}


U1111-1188-0335 (Continued)

Outcomes

Decreased episodes of penetration and aspiration (verified by objective examination of swallowing), nasoendoscopy

\begin{tabular}{ll}
\hline Starting date & 2015 \\
\hline Contact information & Paula Cristina Cola, paccola@hotmail.com \\
\hline Notes & Funding: Faculdade Filosofia e Ciências de Marília \\
\hline
\end{tabular}

C: control

EMG: electromyography

EuroQoL: European Quality of Life Scale

FEES: Fibreoptic Endoscopic Evaluation of Swallowing

MASA: Mann Assessment of Swallowing Ability

MEP: motor evoked potential

mRS: modified Rankin Scale

NG: nasogastric

NIHSS: National Institutes of Health Stroke Scale

PAS: Penetration Aspiration Scale

PEG: percutaneous endoscopic gastroscopy

$\mathrm{RCT}$ : randomised controlled trial

rTMS: repetitive transcranial magnetic stimulation

Rx: treatment

SD: standard deviation

SLT: speech and language therapy

SWAL-QOL: Swallowing Quality of Life Questionnaire

tDCS: transcranial direct current stimulation

TMS: transcranial magnetic stimulation

VFSS: videofluoroscopy swallow study

VGF: no explanation provided on website as to abbreviation

\section{DATA AND ANALYSES}

\section{Comparison 1. Swallowing therapy}

\begin{tabular}{lllll}
\hline Outcome or subgroup title & No. of studies & $\begin{array}{l}\text { No. of partici- } \\
\text { pants }\end{array}$ & Statistical method & Effect size \\
\hline $\begin{array}{l}\text { 1 Functional outcome - death or } \\
\text { dependency, death or disability } \\
\text { at end of trial }\end{array}$ & 2 & 306 & $\begin{array}{l}\text { Odds Ratio (M-H, Random, 95\% } \\
\text { Cl) }\end{array}$ & $1.05[0.63,1.75]$ \\
\hline $\begin{array}{llll}1.1 \text { Behavioural interventions } \\
\text { 2 Case fatality at end of trial }\end{array}$ & 14 & 306 & $\begin{array}{l}\text { Odds Ratio (M-H, Random, 95\% } \\
\text { Cl) }\end{array}$ & $1.05[0.63,1.75]$ \\
\hline 2.1 Behavioural interventions & 2 & 766 & $\begin{array}{l}\text { Odds Ratio (M-H, Random, 95\% } \\
\text { Cl) }\end{array}$ & $1.00[0.66,1.52]$ \\
\hline 2.2 Drug therapy & 306 & & $\begin{array}{l}\text { Odds Ratio (M-H, Random, 95\% } \\
\text { Cl) }\end{array}$ & $0.83[0.46,1.51]$ \\
\hline
\end{tabular}




\begin{tabular}{|c|c|c|c|c|}
\hline Outcome or subgroup title & No. of studies & $\begin{array}{l}\text { No. of partici- } \\
\text { pants }\end{array}$ & Statistical method & Effect size \\
\hline $\begin{array}{l}2.3 \text { Pharyngeal electrical stimu- } \\
\text { lation }\end{array}$ & 4 & 215 & $\begin{array}{l}\text { Odds Ratio (M-H, Random, 95\% } \\
\mathrm{Cl} \text { ) }\end{array}$ & $0.92[0.38,2.26]$ \\
\hline $\begin{array}{l}\text { 2.4 Physical stimulation (ther- } \\
\text { mal, tactile) }\end{array}$ & 1 & 19 & $\begin{array}{l}\text { Odds Ratio (M-H, Random, 95\% } \\
\mathrm{Cl} \text { ) }\end{array}$ & $1.05[0.16,6.92]$ \\
\hline $\begin{array}{l}2.5 \text { Transcranial magnetic stim- } \\
\text { ulation }\end{array}$ & 4 & 78 & $\begin{array}{l}\text { Odds Ratio (M-H, Random, 95\% } \\
\mathrm{Cl} \text { ) }\end{array}$ & $0.28[0.03,2.93]$ \\
\hline 3 Length of inpatient stay (days) & 8 & 577 & $\begin{array}{l}\text { Mean Difference (IV, Random, } \\
95 \% \mathrm{CI})\end{array}$ & $-2.90[-5.65,-0.15]$ \\
\hline 3.1 Behavioural interventions & 4 & 370 & $\begin{array}{l}\text { Mean Difference (IV, Random, } \\
95 \% \mathrm{CI})\end{array}$ & $-2.70[-5.68,0.28]$ \\
\hline $\begin{array}{l}\text { 3.2 Pharyngeal electrical stimu- } \\
\text { lation }\end{array}$ & 4 & 207 & $\begin{array}{l}\text { Mean Difference (IV, Random, } \\
95 \% \mathrm{CI})\end{array}$ & $-6.05[-16.40,4.31]$ \\
\hline $\begin{array}{l}4 \text { Proportion of participants } \\
\text { with dysphagia at end of trial }\end{array}$ & 23 & 1487 & $\begin{array}{l}\text { Odds Ratio (M-H, Random, 95\% } \\
\mathrm{Cl} \text { ) }\end{array}$ & $0.42[0.32,0.55]$ \\
\hline 4.1 Acupuncture & 8 & 676 & $\begin{array}{l}\text { Odds Ratio (M-H, Random, 95\% } \\
\mathrm{Cl} \text { ) }\end{array}$ & $0.31[0.20,0.49]$ \\
\hline 4.2 Behavioural interventions & 6 & 511 & $\begin{array}{l}\text { Odds Ratio (M-H, Random, 95\% } \\
\mathrm{Cl} \text { ) }\end{array}$ & $0.45[0.28,0.74]$ \\
\hline 4.3 Drug therapy & 1 & 17 & $\begin{array}{l}\text { Odds Ratio (M-H, Random, 95\% } \\
\mathrm{Cl} \text { ) }\end{array}$ & $0.48[0.07,3.35]$ \\
\hline $\begin{array}{l}\text { 4.4 Neuromuscular electrical } \\
\text { stimulation }\end{array}$ & 2 & 76 & $\begin{array}{l}\text { Odds Ratio (M-H, Random, 95\% } \\
\mathrm{Cl} \text { ) }\end{array}$ & $0.51[0.18,1.49]$ \\
\hline $\begin{array}{l}\text { 4.5 Pharyngeal electrical stimu- } \\
\text { lation }\end{array}$ & 3 & 66 & $\begin{array}{l}\text { Odds Ratio (M-H, Random, 95\% } \\
\mathrm{Cl} \text { ) }\end{array}$ & $0.55[0.15,2.11]$ \\
\hline $\begin{array}{l}\text { 4.6 Physical stimulation (ther- } \\
\text { mal, tactile) }\end{array}$ & 2 & 127 & $\begin{array}{l}\text { Odds Ratio (M-H, Random, 95\% } \\
\mathrm{Cl} \text { ) }\end{array}$ & $0.65[0.07,5.85]$ \\
\hline $\begin{array}{l}4.7 \text { Transcranial direct current } \\
\text { stimulation }\end{array}$ & 1 & 14 & $\begin{array}{l}\text { Odds Ratio (M-H, Random, 95\% } \\
\mathrm{Cl} \text { ) }\end{array}$ & $0.29[0.01,8.39]$ \\
\hline 5 Swallowing ability & 26 & 1173 & $\begin{array}{l}\text { Std. Mean Difference (IV, Random, } \\
95 \% \mathrm{CI} \text { ) }\end{array}$ & $-0.66[-1.01,-0.32]$ \\
\hline 5.1 Acupuncture & 6 & 496 & $\begin{array}{l}\text { Std. Mean Difference (IV, Random, } \\
95 \% \mathrm{CI} \text { ) }\end{array}$ & $-0.55[-1.20,0.11]$ \\
\hline 5.2 Behavioural intervention & 3 & 121 & $\begin{array}{l}\text { Std. Mean Difference (IV, Random, } \\
95 \% \mathrm{Cl} \text { ) }\end{array}$ & $-0.56[-1.07,-0.05]$ \\
\hline 5.3 Drug therapy & 1 & 71 & $\begin{array}{l}\text { Std. Mean Difference (IV, Random, } \\
95 \% \mathrm{Cl} \text { ) }\end{array}$ & $-0.46[-0.93,0.01]$ \\
\hline
\end{tabular}




\begin{tabular}{|c|c|c|c|c|}
\hline Outcome or subgroup title & No. of studies & $\begin{array}{l}\text { No. of partici- } \\
\text { pants }\end{array}$ & Statistical method & Effect size \\
\hline $\begin{array}{l}\text { 5.4 Neuromuscular electrical } \\
\text { stimulation }\end{array}$ & 2 & 100 & $\begin{array}{l}\text { Std. Mean Difference (IV, Random, } \\
95 \% \mathrm{Cl})\end{array}$ & $-1.34[-3.39,0.71]$ \\
\hline $\begin{array}{l}5.5 \text { Pharyngeal electrical stimu- } \\
\text { lation }\end{array}$ & 3 & 194 & $\begin{array}{l}\text { Std. Mean Difference (IV, Random, } \\
95 \% \mathrm{CI})\end{array}$ & $0.06[-0.22,0.34]$ \\
\hline $\begin{array}{l}\text { 5.6 Physical stimulation (ther- } \\
\text { mal, tactile) }\end{array}$ & 1 & 16 & $\begin{array}{l}\text { Std. Mean Difference (IV, Random, } \\
95 \% \mathrm{CI} \text { ) }\end{array}$ & $-0.30[-1.29,0.68]$ \\
\hline $\begin{array}{l}\text { 5.7 Transcranial direct current } \\
\text { stimulation }\end{array}$ & 2 & 34 & $\begin{array}{l}\text { Std. Mean Difference (IV, Random, } \\
95 \% \mathrm{CI} \text { ) }\end{array}$ & $-0.33[-2.22,1.56]$ \\
\hline $\begin{array}{l}\text { 5.8 Transcranial magnetic stim- } \\
\text { ulation }\end{array}$ & 8 & 141 & $\begin{array}{l}\text { Std. Mean Difference (IV, Random, } \\
95 \% \mathrm{CI} \text { ) }\end{array}$ & $-1.29[-2.37,-0.21]$ \\
\hline 6 Penetration aspiration score & 11 & 303 & $\begin{array}{l}\text { Std. Mean Difference (IV, Random, } \\
95 \% \mathrm{CI} \text { ) }\end{array}$ & $-0.37[-0.74,-0.00]$ \\
\hline 6.1 Behavioural intervention & 1 & 27 & $\begin{array}{l}\text { Std. Mean Difference (IV, Random, } \\
95 \% \mathrm{CI} \text { ) }\end{array}$ & $-0.88[-1.68,-0.08]$ \\
\hline $\begin{array}{l}\text { 6.2 Neuromuscular electrical } \\
\text { stimulation }\end{array}$ & 1 & 18 & $\begin{array}{l}\text { Std. Mean Difference (IV, Random, } \\
95 \% \mathrm{CI} \text { ) }\end{array}$ & $0.57[-0.38,1.52]$ \\
\hline $\begin{array}{l}\text { 6.3 Pharyngeal electrical stimu- } \\
\text { lation }\end{array}$ & 4 & 177 & $\begin{array}{l}\text { Std. Mean Difference (IV, Random, } \\
95 \% \mathrm{CI} \text { ) }\end{array}$ & $-0.17[-0.53,0.19]$ \\
\hline $\begin{array}{l}\text { 6.4 Transcranial magnetic stim- } \\
\text { ulation }\end{array}$ & 5 & 81 & $\begin{array}{l}\text { Std. Mean Difference (IV, Random, } \\
95 \% \mathrm{CI} \text { ) }\end{array}$ & $-0.53[-1.22,0.16]$ \\
\hline 7 Chest infection or pneumonia & 9 & 618 & $\begin{array}{l}\text { Odds Ratio (M-H, Random, 95\% } \\
\mathrm{Cl} \text { ) }\end{array}$ & $0.36[0.16,0.78]$ \\
\hline 7.1 Behavioural interventions & 6 & 473 & $\begin{array}{l}\text { Odds Ratio (M-H, Random, 95\% } \\
\mathrm{Cl} \text { ) }\end{array}$ & $0.56[0.31,1.00]$ \\
\hline 7.2 Drug therapy & 1 & 60 & $\begin{array}{l}\text { Odds Ratio (M-H, Random, 95\% } \\
\mathrm{Cl} \text { ) }\end{array}$ & $0.06[0.01,0.21]$ \\
\hline $\begin{array}{l}7.3 \text { Neuromuscular electrical } \\
\text { stimulation }\end{array}$ & 1 & 57 & $\begin{array}{l}\text { Odds Ratio (M-H, Random, 95\% } \\
\mathrm{Cl} \text { ) }\end{array}$ & $0.0[0.0,0.0]$ \\
\hline $\begin{array}{l}\text { 7.4 Pharyngeal electrical stimu- } \\
\text { lation }\end{array}$ & 1 & 28 & $\begin{array}{l}\text { Odds Ratio (M-H, Random, 95\% } \\
\mathrm{Cl} \text { ) }\end{array}$ & $0.43[0.06,3.09]$ \\
\hline $\begin{array}{l}8 \text { Pharyngeal transit time (sec- } \\
\text { onds) }\end{array}$ & 6 & 187 & $\begin{array}{l}\text { Mean Difference (IV, Random, } \\
95 \% \mathrm{CI} \text { ) }\end{array}$ & $-0.23[-0.32,-0.15]$ \\
\hline 8.1 Drug therapy & 1 & 17 & $\begin{array}{l}\text { Mean Difference (IV, Random, } \\
95 \% \mathrm{CI} \text { ) }\end{array}$ & $-0.21[-0.91,0.49]$ \\
\hline $\begin{array}{l}8.2 \text { Neuromuscular electrical } \\
\text { stimulation }\end{array}$ & 3 & 126 & $\begin{array}{l}\text { Mean Difference (IV, Random, } \\
95 \% \mathrm{CI} \text { ) }\end{array}$ & $-0.23[-0.39,-0.08]$ \\
\hline
\end{tabular}




\begin{tabular}{|c|c|c|c|c|}
\hline Outcome or subgroup title & No. of studies & $\begin{array}{l}\text { No. of partici- } \\
\text { pants }\end{array}$ & Statistical method & Effect size \\
\hline $\begin{array}{l}\text { 8.3 Pharyngeal electrical stimu- } \\
\text { lation }\end{array}$ & 1 & 28 & $\begin{array}{l}\text { Mean Difference (IV, Random, } \\
95 \% \mathrm{CI} \text { ) }\end{array}$ & $-0.15[-0.67,0.37]$ \\
\hline $\begin{array}{l}\text { 8.4 Physical stimulation (ther- } \\
\text { mal, tactile) }\end{array}$ & 1 & 16 & $\begin{array}{l}\text { Mean Difference (IV, Random, } \\
95 \% \mathrm{CI})\end{array}$ & $-0.19[-0.34,-0.04]$ \\
\hline 9 Institutionalisation & 3 & 447 & $\begin{array}{l}\text { Odds Ratio (M-H, Random, 95\% } \\
\mathrm{Cl} \text { ) }\end{array}$ & $0.75[0.47,1.19]$ \\
\hline 9.1 Behavioural interventions & 2 & 306 & $\begin{array}{l}\text { Odds Ratio (M-H, Random, 95\% } \\
\text { Cl) }\end{array}$ & $0.76[0.39,1.48]$ \\
\hline $\begin{array}{l}\text { 9.2 Pharyngeal electrical stimu- } \\
\text { lation }\end{array}$ & 1 & 141 & $\begin{array}{l}\text { Odds Ratio (M-H, Random, 95\% } \\
\mathrm{Cl} \text { ) }\end{array}$ & $0.73[0.36,1.48]$ \\
\hline 10 Nutritional (albumin) & 3 & 169 & $\begin{array}{l}\text { Mean Difference (IV, Random, } \\
95 \% \mathrm{CI} \text { ) }\end{array}$ & $0.37[-1.50,2.24]$ \\
\hline 10.1 Behavioural interventions & 2 & 64 & $\begin{array}{l}\text { Mean Difference (IV, Random, } \\
95 \% \mathrm{CI} \text { ) }\end{array}$ & $0.20[-4.77,5.17]$ \\
\hline $\begin{array}{l}\text { 10.2 Pharyngeal electrical stim- } \\
\text { ulation }\end{array}$ & 1 & 105 & $\begin{array}{l}\text { Mean Difference (IV, Random, } \\
95 \% \mathrm{CI} \text { ) }\end{array}$ & $0.40[-1.62,2.42]$ \\
\hline
\end{tabular}

\section{Analysis 1.1. Comparison 1 Swallowing therapy, Outcome 1 Functional outcome - death or dependency, death or disability at end of trial.}

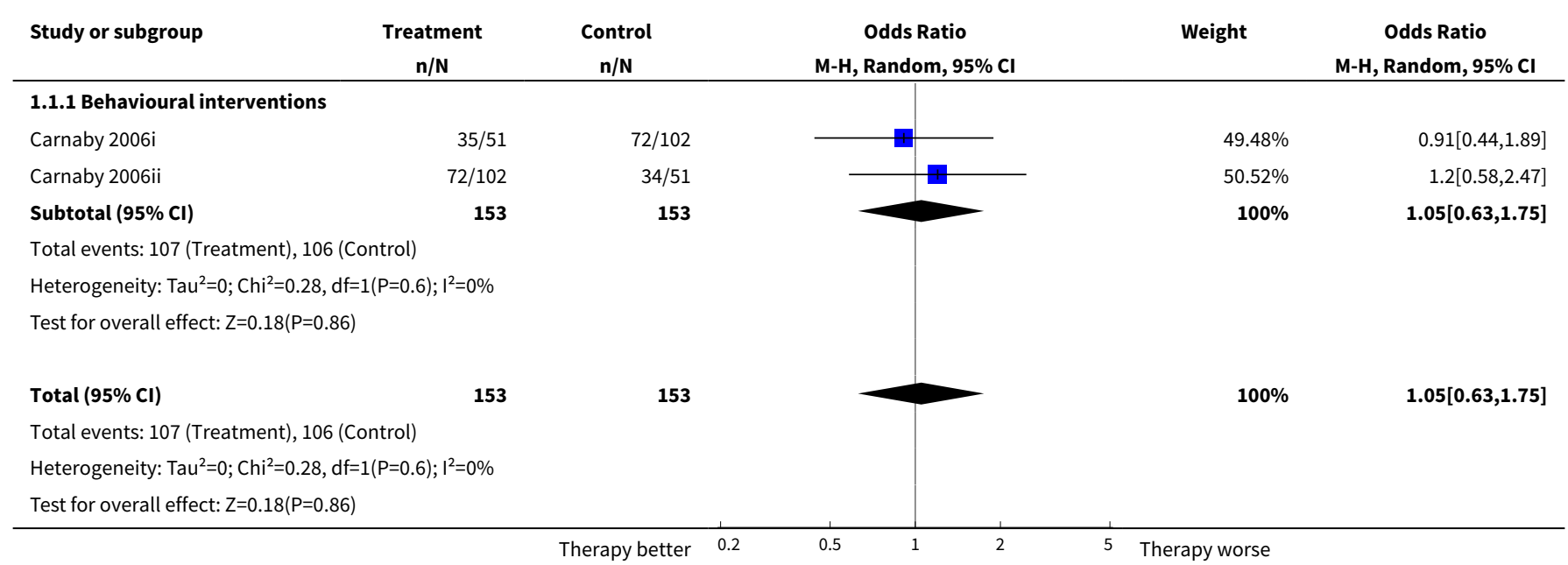


Analysis 1.2. Comparison 1 Swallowing therapy, Outcome 2 Case fatality at end of trial.

\begin{tabular}{|c|c|c|}
\hline Study or subgroup & $\begin{array}{c}\text { Treatment } \\
\mathbf{n} / \mathbf{N}\end{array}$ & $\begin{array}{c}\text { Control } \\
n / N\end{array}$ \\
\hline \multicolumn{3}{|c|}{ 1.2.1 Behavioural interventions } \\
\hline Carnaby $2006 i$ & $10 / 51$ & $23 / 102$ \\
\hline Carnaby $2006 \mathrm{ii}$ & $17 / 102$ & $10 / 51$ \\
\hline Subtotal $(95 \% \mathrm{Cl})$ & 153 & 153 \\
\hline \multicolumn{3}{|c|}{ Total events: 27 (Treatment), 33 (Control) } \\
\hline \multicolumn{3}{|c|}{ Heterogeneity: Tau $^{2}=0 ; \mathrm{Chi}^{2}=0, \mathrm{df}=1(\mathrm{P}=0.97) ; \mathrm{I}^{2}=0 \%$} \\
\hline \multicolumn{3}{|c|}{ Test for overall effect: $Z=0.61(P=0.54)$} \\
\hline \multicolumn{3}{|l|}{ 1.2.2 Drug therapy } \\
\hline Lee 2015 & $19 / 33$ & $10 / 38$ \\
\hline Perez 1997 & $1 / 8$ & $1 / 9$ \\
\hline Warusevitane 2015 & $8 / 30$ & $12 / 30$ \\
\hline Subtotal $(95 \% \mathrm{Cl})$ & 71 & 77 \\
\hline
\end{tabular}

Total events: 28 (Treatment), 23 (Control)

Heterogeneity: $\mathrm{Tau}^{2}=1.13 ; \mathrm{Chi}^{2}=6.66, \mathrm{df}=2(\mathrm{P}=0.04) ; \mathrm{I}^{2}=69.98 \%$

Test for overall effect: $Z=0.44(P=0.66)$

\subsubsection{Pharyngeal electrical stimulation}

Jayasekeran 2010a

Total events: 12 (Treatment), 10 (Control)

Heterogeneity: $\mathrm{Tau}^{2}=0 ; \mathrm{Chi}^{2}=1.05, \mathrm{df}=2(\mathrm{P}=0.59) ; \mathrm{I}^{2}=0 \%$

Test for overall effect: $Z=0.18(P=0.86)$

\subsubsection{Physical stimulation (thermal, tactile)}

Bath 1997

Total events: 7 (Treatment), 5 (Control)

Heterogeneity: Not applicable

Test for overall effect: $Z=0.05(P=0.96)$

\subsubsection{Transcranial magnetic stimulation}

Khedr 2009

Khedr 2010

\section{Total events: 0 (Treatment), 2 (Control)}

53

Total events: 74 (Treatment), 73 (Control)

Heterogeneity: $\mathrm{Tau}^{2}=0.03 ; \mathrm{Chi}^{2}=10.64, \mathrm{df}=10(\mathrm{P}=0.39) ; \mathrm{I}^{2}=5.98 \%$ Test for overall effect: $Z=0.01(P=0.99)$

Test for subgroup differences: $\mathrm{Chi}^{2}=1.36, \mathrm{df}=1(\mathrm{P}=0.85), \mathrm{I}^{2}=0 \%$

3.8[1.4,10.32]

$1.14[0.06,21.87]$ $0.55[0.18,1.62]$

$1.4[0.31,6.28]$
$4.31[0.19,98.51]$

$0.78[0.29,2.11]$

$1[0.06,17.33]$

$0.92[0.38,2.26]$
$0.26[0.01,7.12]$

$1.59 \%$
$0.3[0.01,8.32]$

Not estimable

Not estimable

$0.28[0.03,2.93]$ 
Analysis 1.3. Comparison 1 Swallowing therapy, Outcome 3 Length of inpatient stay (days).

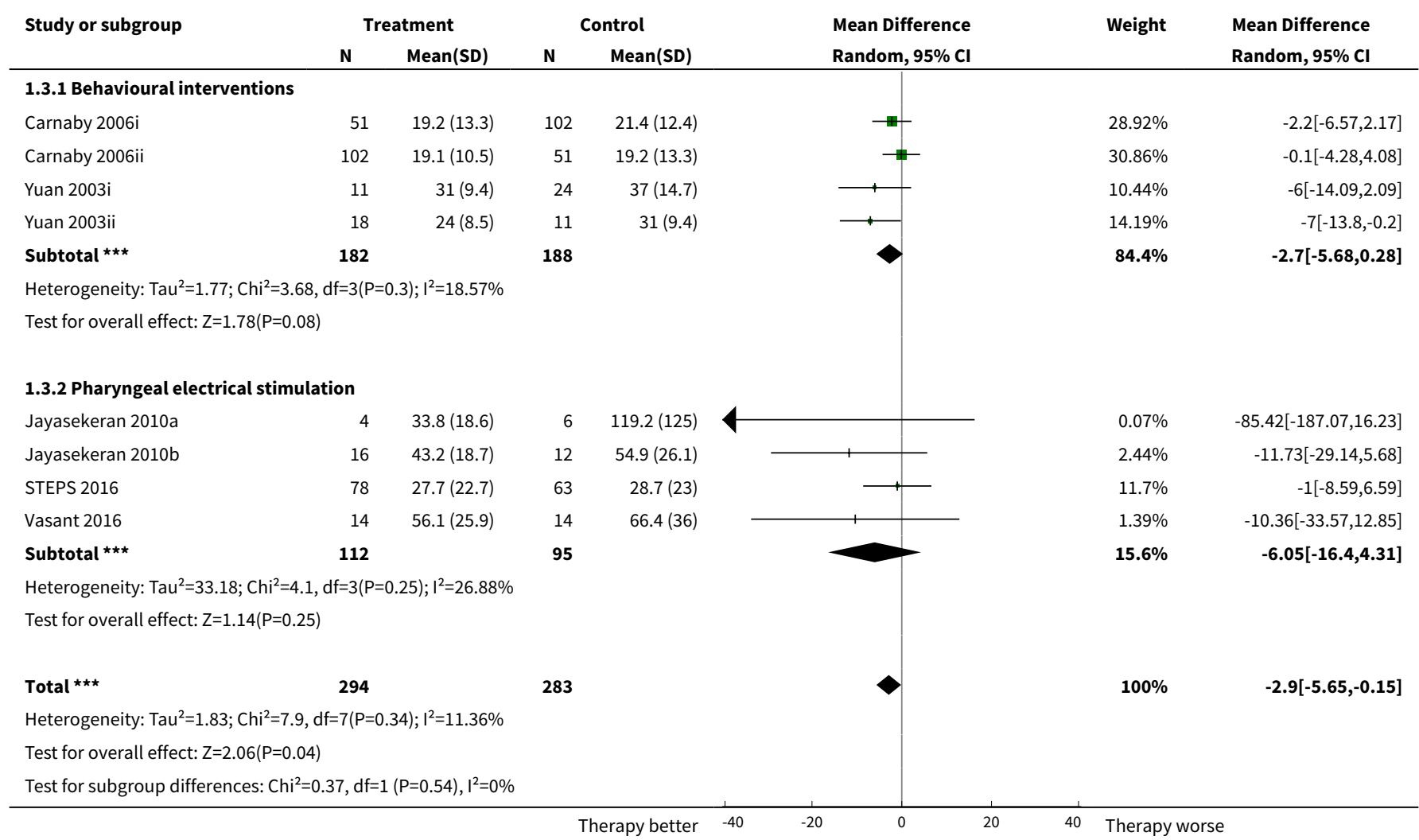

Analysis 1.4. Comparison 1 Swallowing therapy, Outcome 4 Proportion of participants with dysphagia at end of trial.

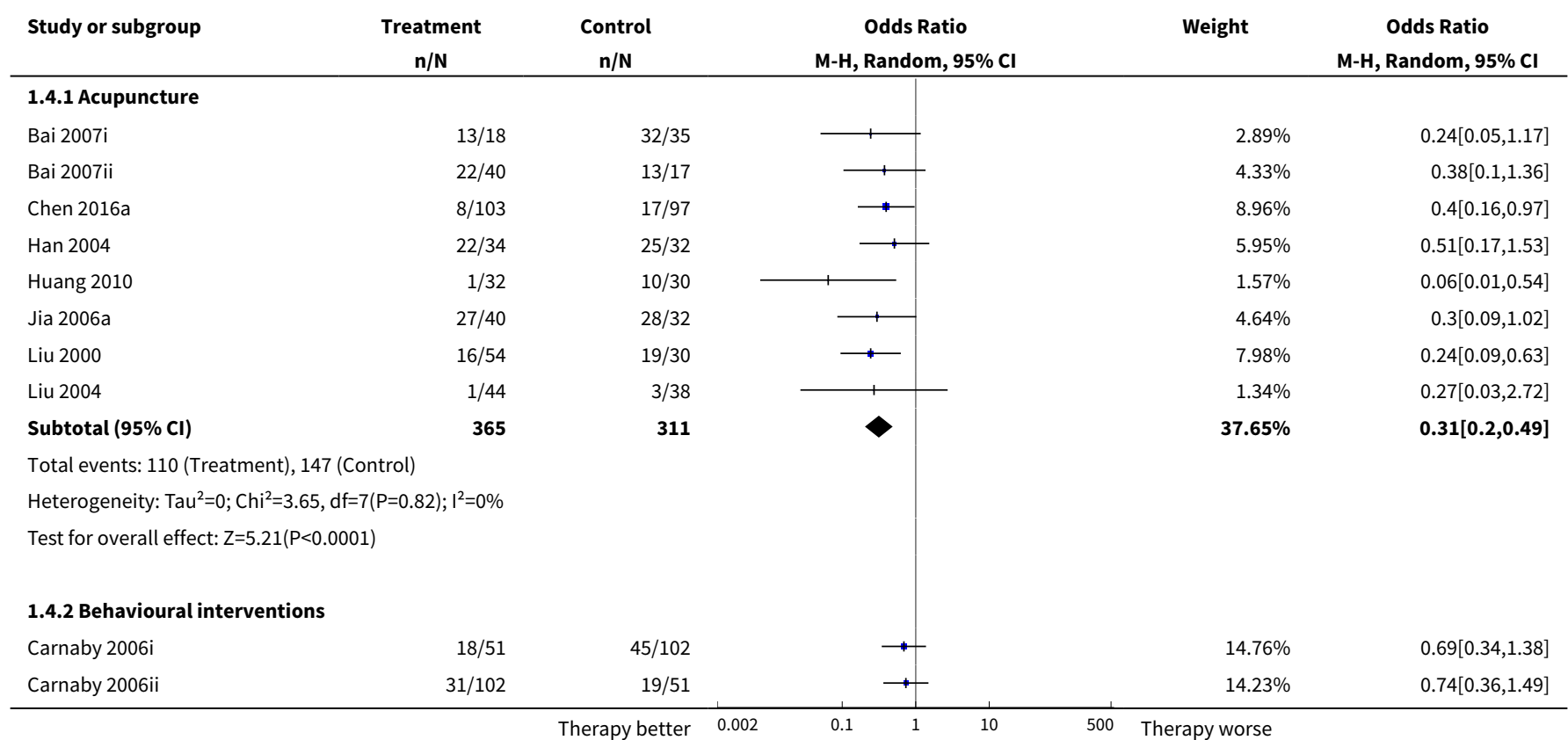




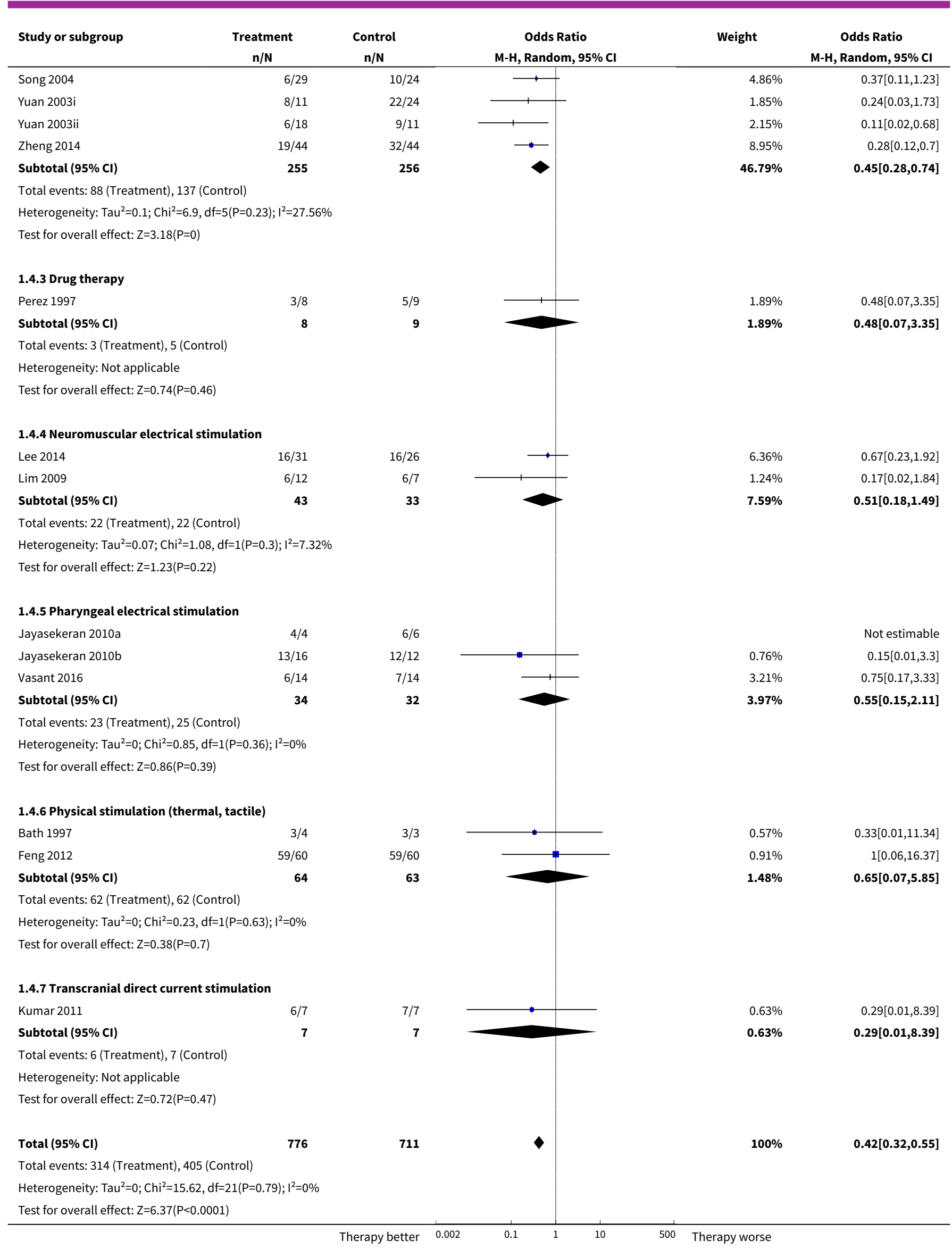




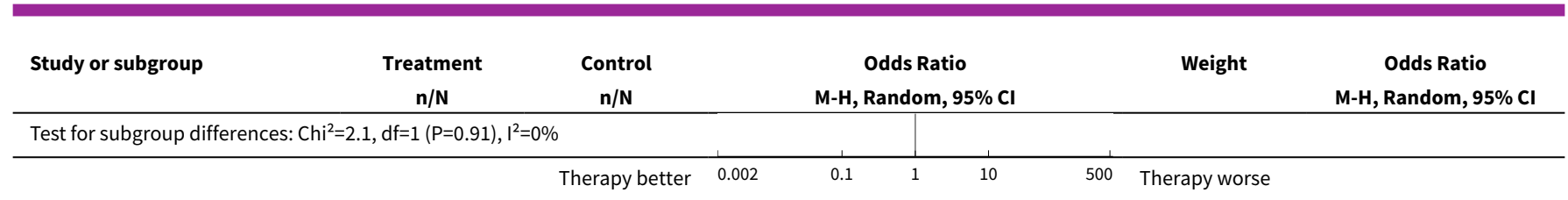

Analysis 1.5. Comparison 1 Swallowing therapy, Outcome 5 Swallowing ability.

\begin{tabular}{|c|c|c|c|c|c|c|c|}
\hline \multirow[t]{2}{*}{ Study or subgroup } & \multicolumn{2}{|c|}{ Treatment } & \multicolumn{2}{|c|}{ Control } & \multirow{2}{*}{$\begin{array}{c}\text { Std. Mean Difference } \\
\text { Random, } 95 \% \mathrm{Cl} \\
\end{array}$} & \multirow[t]{2}{*}{ Weight } & \multirow{2}{*}{$\begin{array}{l}\text { Std. Mean Difference } \\
\text { Random, } 95 \% \mathrm{Cl}\end{array}$} \\
\hline & $\mathbf{N}$ & Mean(SD) & $\mathbf{N}$ & Mean(SD) & & & \\
\hline \multicolumn{8}{|l|}{ 1.5.1 Acupuncture } \\
\hline Bai 2007i & 18 & $5.5(1.2)$ & 35 & $6(1.4)$ & + & $4.34 \%$ & $-0.41[-0.98,0.17]$ \\
\hline Bai 2007ii & 40 & $4.2(1.4)$ & 17 & $5.5(1.2)$ & + & $4.31 \%$ & $-0.91[-1.5,-0.32]$ \\
\hline Chan 2012 & 48 & $5.6(1)$ & 20 & $5.8(1)$ & + & $4.43 \%$ & $-0.21[-0.73,0.31]$ \\
\hline Chen 2016a & 65 & $9.4(0.8)$ & 68 & $9.8(0.5)$ & + & $4.69 \%$ & $-0.67[-1.02,-0.32]$ \\
\hline Wei 2005 & 32 & $5.5(0.8)$ & 33 & $5(0.6)$ & + & $4.47 \%$ & $0.69[0.19,1.19]$ \\
\hline Xia 2016a & 60 & $3.7(1.1)$ & 60 & $5.8(1.3)$ & + & $4.59 \%$ & $-1.73[-2.15,-1.31]$ \\
\hline Subtotal ${ }^{\star \star \star}$ & 263 & & 233 & & 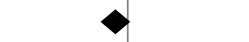 & $26.84 \%$ & $-0.55[-1.2,0.11]$ \\
\hline \multicolumn{8}{|c|}{ Heterogeneity: $\mathrm{Tau}^{2}=0.61 ; \mathrm{Chi}^{2}=56.73, \mathrm{df}=5(\mathrm{P}<0.0001) ; \mathrm{I}^{2}=91.19 \%$} \\
\hline \multicolumn{8}{|c|}{ Test for overall effect: $\mathrm{Z}=1.63(\mathrm{P}=0.1)$} \\
\hline \multicolumn{8}{|c|}{ 1.5.2 Behavioural intervention } \\
\hline Heo 2015 & 22 & $25.7(10)$ & 22 & $26.7(10.5)$ & + & $4.31 \%$ & $-0.1[-0.69,0.5]$ \\
\hline Kang 2012 & 25 & $3.6(1.2)$ & 25 & $4.6(1)$ & + & $4.33 \%$ & $-0.89[-1.47,-0.31]$ \\
\hline Park 2016b & 14 & $4.4(0.8)$ & 13 & $5.4(1.7)$ & + & $3.94 \%$ & $-0.74[-1.52,0.05]$ \\
\hline 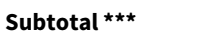 & 61 & & 60 & & $\diamond$ & $12.58 \%$ & $-0.56[-1.07,-0.05]$ \\
\hline \multicolumn{8}{|c|}{ Heterogeneity: $\mathrm{Tau}^{2}=0.1 ; \mathrm{Chi}^{2}=3.8, \mathrm{df}=2(\mathrm{P}=0.15) ; \mathrm{I}^{2}=47.4 \%$} \\
\hline \multicolumn{8}{|c|}{ Test for overall effect: $Z=2.14(P=0.03)$} \\
\hline \multicolumn{8}{|l|}{ 1.5.3 Drug therapy } \\
\hline Lee 2015 & 38 & $3.5(1.5)$ & 33 & $4.2(1.5)$ & + & $4.52 \%$ & $-0.46[-0.93,0.01]$ \\
\hline 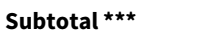 & 38 & & 33 & & $\checkmark$ & $4.52 \%$ & $-0.46[-0.93,0.01]$ \\
\hline \multicolumn{8}{|c|}{ Heterogeneity: Not applicable } \\
\hline \multicolumn{8}{|c|}{ Test for overall effect: $Z=1.91(P=0.06)$} \\
\hline \multicolumn{8}{|c|}{ 1.5.4 Neuromuscular electrical stimulation } \\
\hline Terre 2015 & 10 & $4.6(2.5)$ & 10 & $5.3(2.5)$ & + & $3.74 \%$ & $-0.27[-1.15,0.61]$ \\
\hline Xia 2011 & 40 & $21.4(3.5)$ & 40 & $30.1(3.8)$ & + & $4.34 \%$ & $-2.36[-2.94,-1.78]$ \\
\hline Subtotal $\star \star \star ~$ & 50 & & 50 & & & $8.08 \%$ & $-1.34[-3.39,0.71]$ \\
\hline \multicolumn{8}{|c|}{ Heterogeneity: $\operatorname{Tau}^{2}=2.04 ; \mathrm{Chi}^{2}=15.13, \mathrm{df}=1(\mathrm{P}=0) ; 1^{2}=93.39 \%$} \\
\hline \multicolumn{8}{|c|}{ Test for overall effect: $\mathrm{Z}=1.28(\mathrm{P}=0.2)$} \\
\hline \multicolumn{8}{|c|}{ 1.5.5 Pharyngeal electrical stimulation } \\
\hline Jayasekeran 2010b & 16 & $6.3(4.4)$ & 12 & $5.6(5.5)$ & + & $4.01 \%$ & $0.14[-0.61,0.89]$ \\
\hline STEPS 2016 & 72 & $5.2(4.1)$ & 59 & $4.9(3.6)$ & + & $4.7 \%$ & $0.08[-0.27,0.42]$ \\
\hline Vasant 2016 & 18 & $4.3(4)$ & 17 & $4.6(4.4)$ & + & $4.18 \%$ & $-0.07[-0.74,0.59]$ \\
\hline 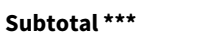 & 106 & & 88 & & 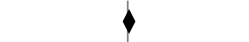 & $12.89 \%$ & $0.06[-0.22,0.34]$ \\
\hline \multicolumn{8}{|c|}{ Heterogeneity: $\operatorname{Tau}^{2}=0 ; \mathrm{Chi}^{2}=0.2, \mathrm{df}=2(\mathrm{P}=0.9) ; \mathrm{I}^{2}=0 \%$} \\
\hline \multicolumn{8}{|c|}{ Test for overall effect: $\mathrm{Z}=0.4(\mathrm{P}=0.69)$} \\
\hline \multicolumn{8}{|c|}{ 1.5.6 Physical stimulation (thermal, tactile) } \\
\hline Power 2006 & 8 & $24.9(4.7)$ & 8 & $26.3(4.1)$ & + & $3.53 \%$ & $-0.3[-1.29,0.68]$ \\
\hline
\end{tabular}




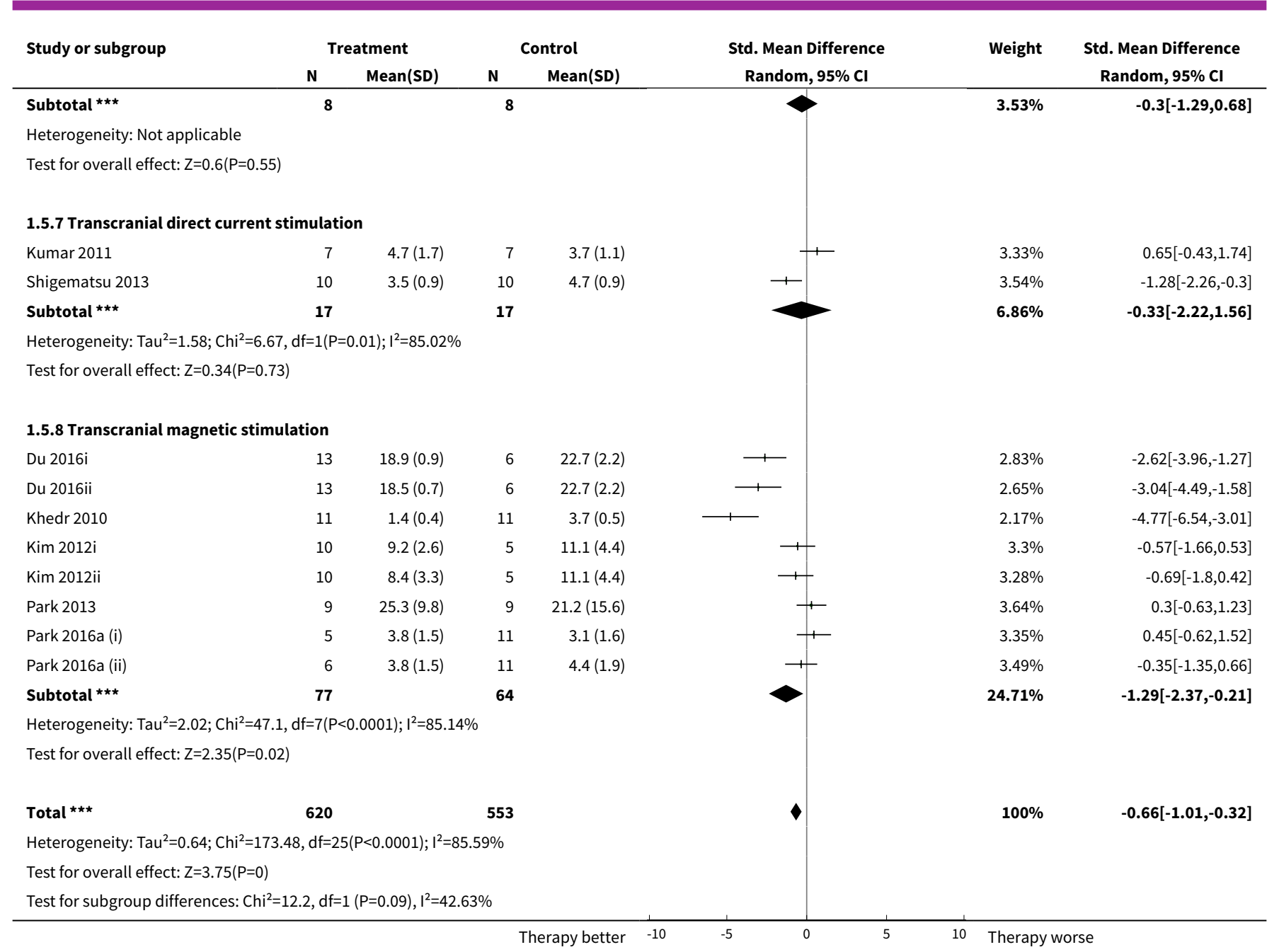

Analysis 1.6. Comparison 1 Swallowing therapy, Outcome 6 Penetration aspiration score.

\begin{tabular}{|c|c|c|c|c|c|c|c|}
\hline \multirow[t]{2}{*}{ Study or subgroup } & \multicolumn{2}{|c|}{ Treatment } & \multicolumn{2}{|c|}{ Control } & \multirow{2}{*}{$\begin{array}{c}\text { Std. Mean Difference } \\
\text { Random, } 95 \% \mathrm{Cl}\end{array}$} & \multirow[t]{2}{*}{ Weight } & \multirow{2}{*}{$\begin{array}{c}\text { Std. Mean Difference } \\
\text { Random, } 95 \% \mathrm{Cl}\end{array}$} \\
\hline & $\mathbf{N}$ & $\operatorname{Mean}(S D)$ & $\mathbf{N}$ & $\operatorname{Mean}(\mathrm{SD})$ & & & \\
\hline \multicolumn{5}{|c|}{ 1.6.1 Behavioural intervention } & & & \\
\hline Park 2016b & 14 & $4.9(0.5)$ & 13 & $5.5(0.8)$ & $\longrightarrow$ & $10.82 \%$ & $-0.88[-1.68,-0.08]$ \\
\hline Subtotal $\star \star \star$ & 14 & & 13 & & & $10.82 \%$ & $-0.88[-1.68,-0.08]$ \\
\hline \multicolumn{8}{|c|}{ Heterogeneity: $\mathrm{Tau}^{2}=0 ; \mathrm{Chi}^{2}=0, \mathrm{df}=0(\mathrm{P}<0.0001) ; \mathrm{I}^{2}=100 \%$} \\
\hline \multicolumn{8}{|c|}{ Test for overall effect: $Z=2.17(P=0.03)$} \\
\hline \multicolumn{8}{|c|}{ 1.6.2 Neuromuscular electrical stimulation } \\
\hline Park 2012 & 9 & $3.2(2.1)$ & 9 & $2.2(1.4)$ & * & $8.94 \%$ & $0.57[-0.38,1.52]$ \\
\hline Subtotal $\star \star \star ~$ & 9 & & 9 & & & $8.94 \%$ & $0.57[-0.38,1.52]$ \\
\hline \multicolumn{8}{|c|}{ Heterogeneity: Not applicable } \\
\hline \multicolumn{8}{|c|}{ Test for overall effect: $Z=1.17(P=0.24)$} \\
\hline \multicolumn{8}{|c|}{ 1.6.3 Pharyngeal electrical stimulation } \\
\hline Jayasekeran 2010a & 4 & $3.7(1.3)$ & 6 & $4.8(1.3)$ & 1 & $5.61 \%$ & $-0.78[-2.12,0.56]$ \\
\hline Jayasekeran 2010b & 16 & $3.2(1.5)$ & 12 & $3.8(1.3)$ & \begin{tabular}{l|l}
1 & \\
\end{tabular} & $11.37 \%$ & $-0.41[-1.17,0.35]$ \\
\hline
\end{tabular}




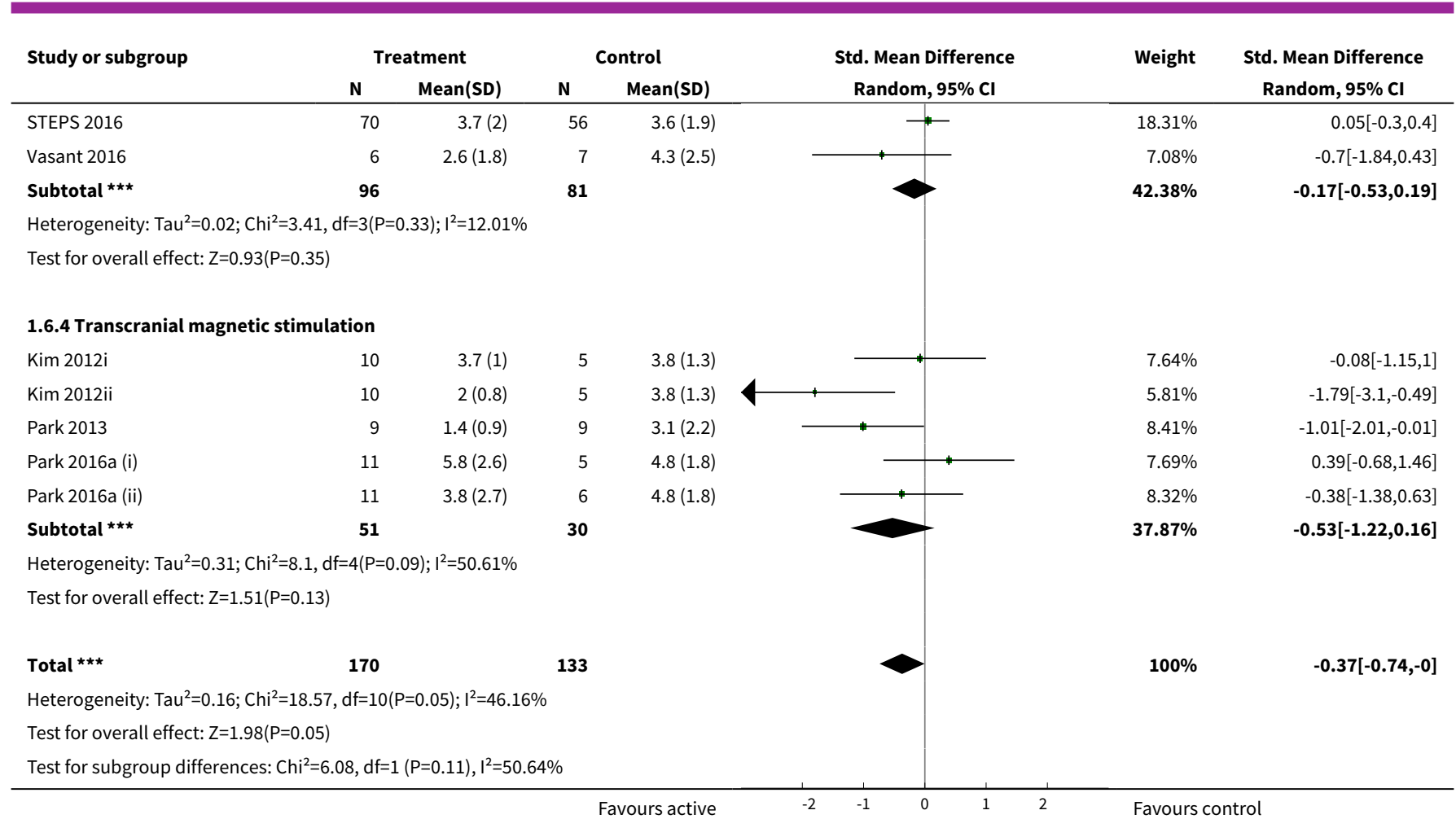

Analysis 1.7. Comparison 1 Swallowing therapy, Outcome 7 Chest infection or pneumonia.

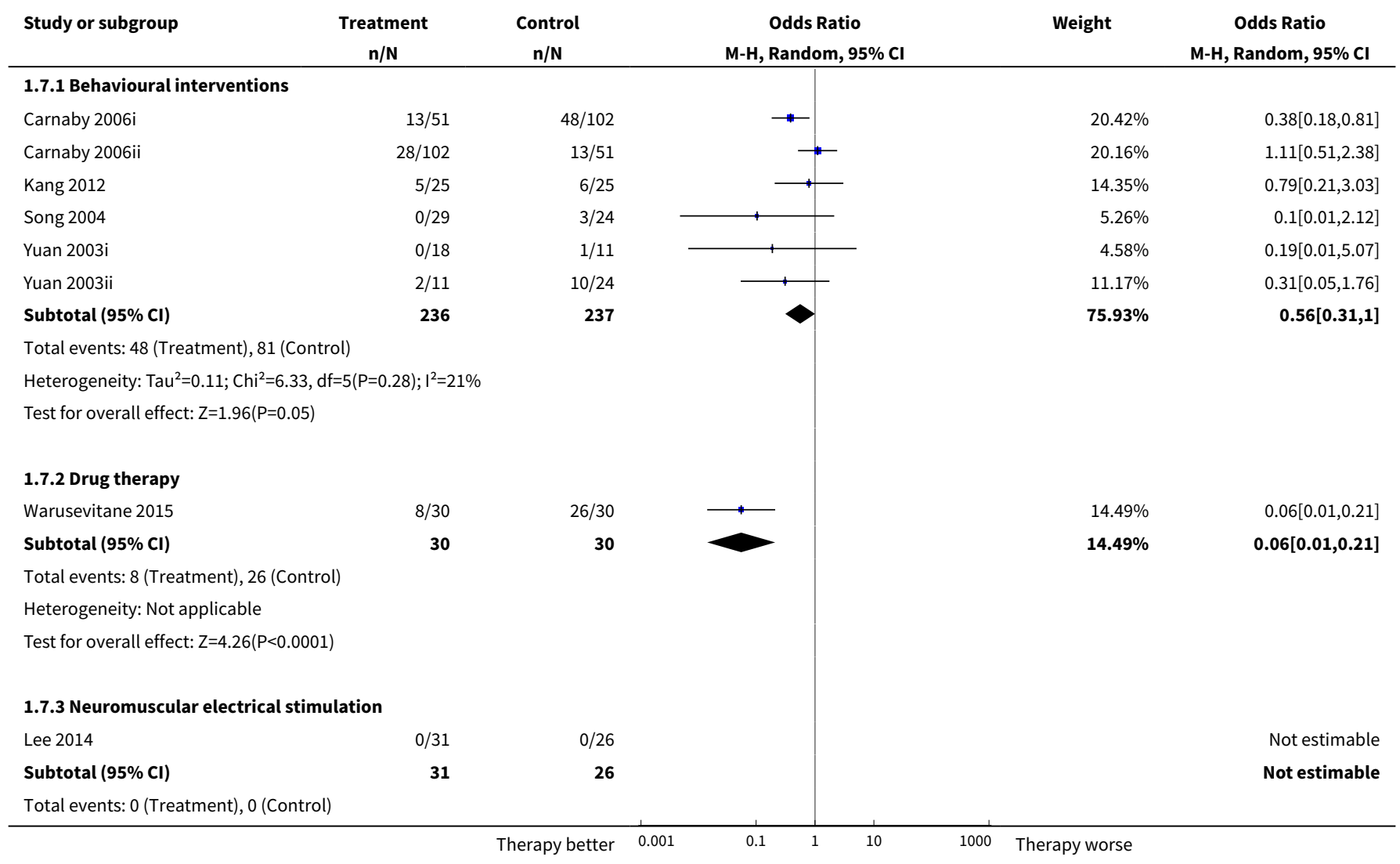




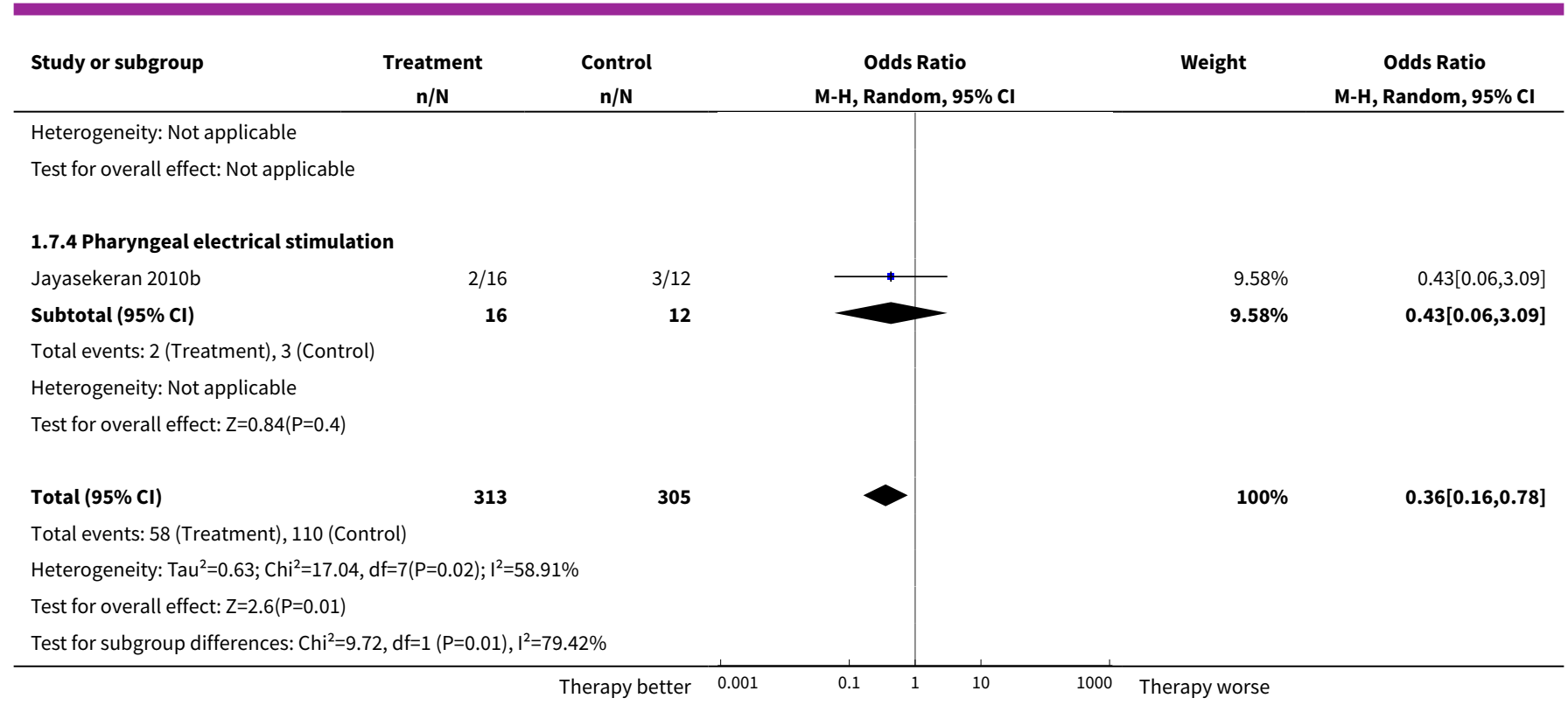

Analysis 1.8. Comparison 1 Swallowing therapy, Outcome 8 Pharyngeal transit time (seconds).

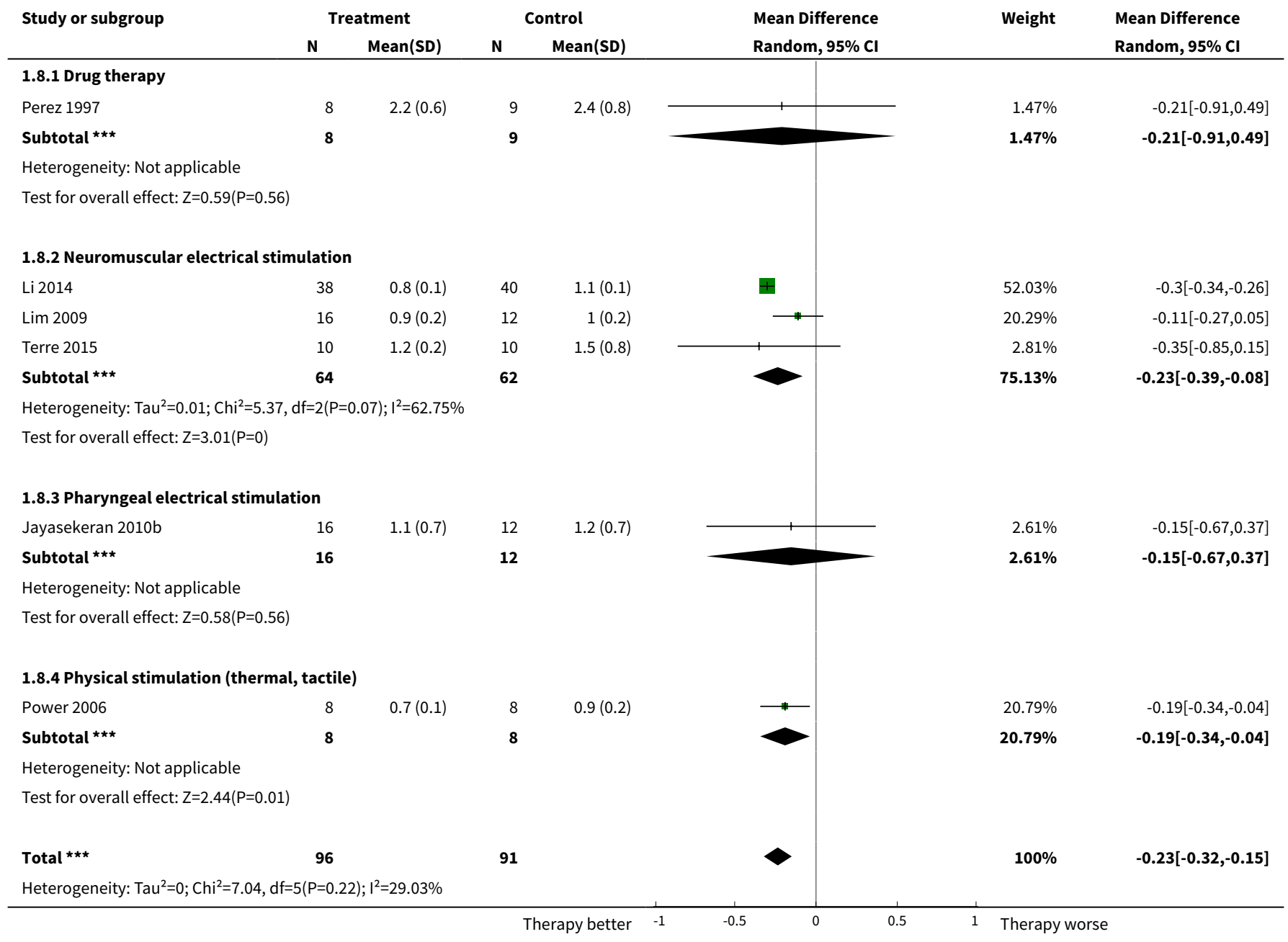




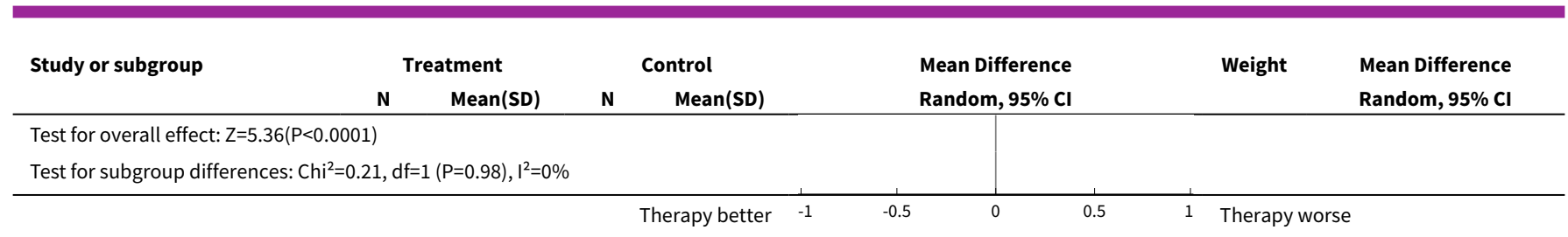

Analysis 1.9. Comparison 1 Swallowing therapy, Outcome 9 Institutionalisation.

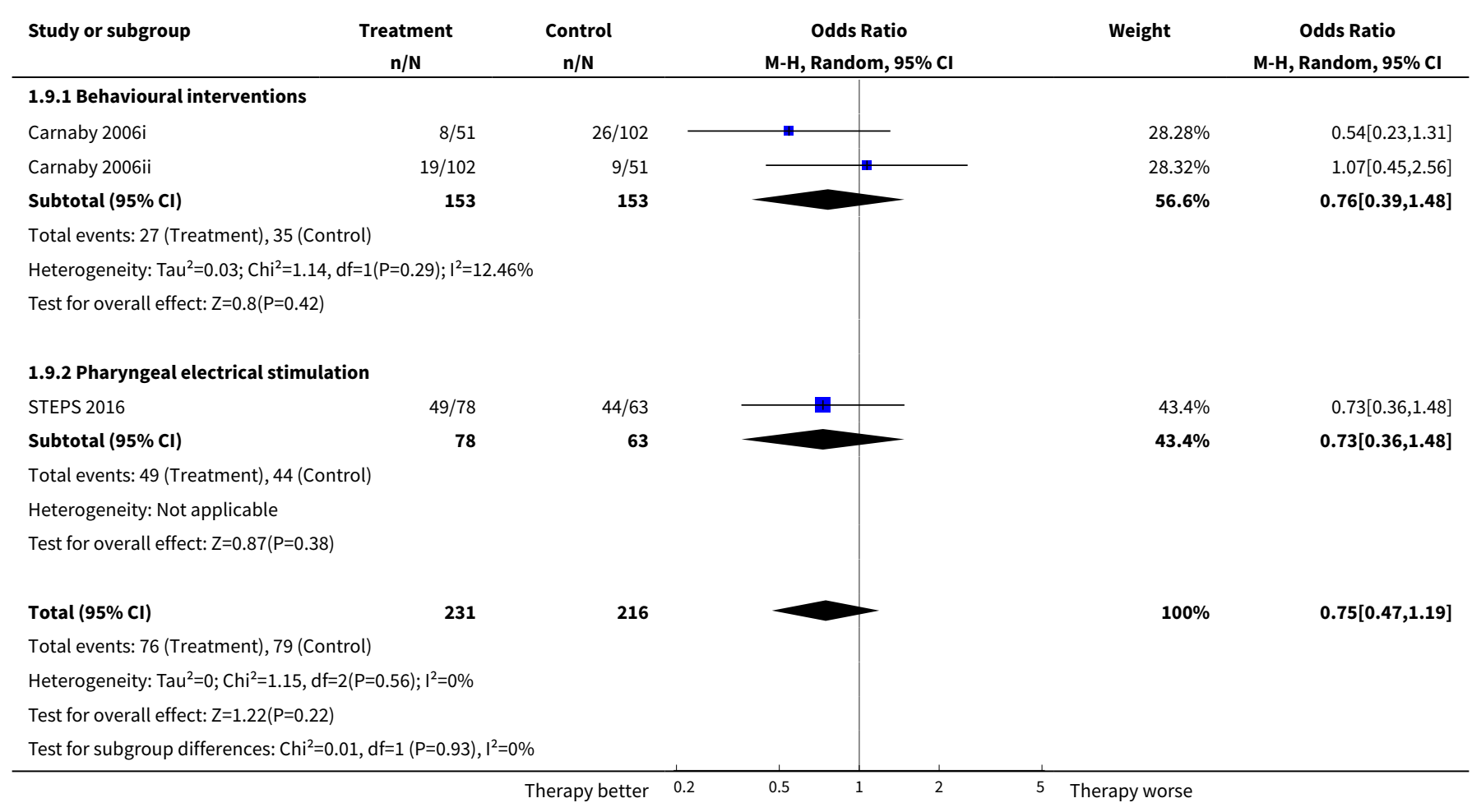

\section{Analysis 1.10. Comparison 1 Swallowing therapy, Outcome 10 Nutritional (albumin).}

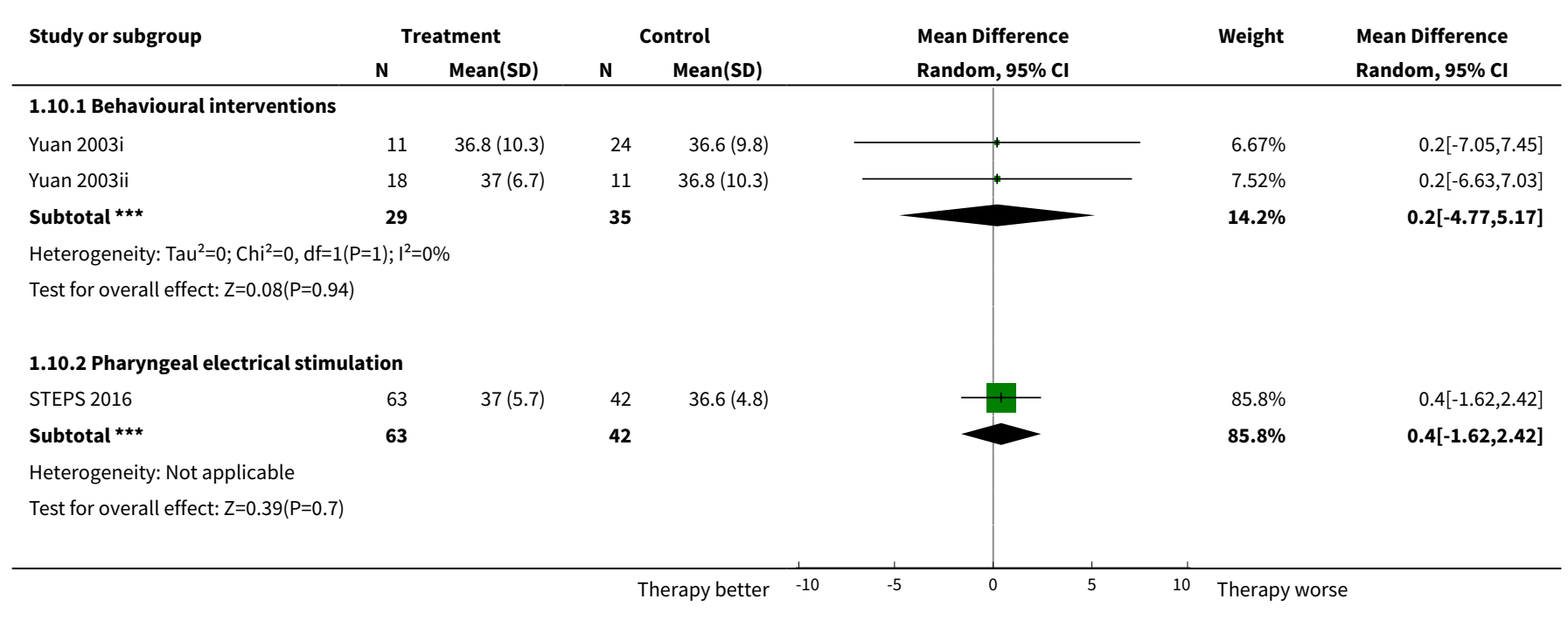




\begin{tabular}{|c|c|c|c|c|c|}
\hline \multirow[t]{2}{*}{ Study or subgroup } & Treatment & Control & \multirow{2}{*}{$\begin{array}{l}\text { Mean Difference } \\
\text { Random, } 95 \% \mathrm{Cl}\end{array}$} & \multirow[t]{2}{*}{ Weight } & \multirow{2}{*}{$\begin{array}{l}\text { Mean Difference } \\
\text { Random, 95\% Cl }\end{array}$} \\
\hline & Mean(SD) & Mean(SD) & & & \\
\hline Total $* \star \star$ & 92 & 77 & & $100 \%$ & $0.37[-1.5,2.24]$ \\
\hline \multicolumn{6}{|c|}{ Heterogeneity: $\mathrm{Tau}^{2}=0 ; \mathrm{Chi}^{2}=0.01, \mathrm{df}=2(\mathrm{P}=1) ; \mathrm{I}^{2}=0 \%$} \\
\hline \multicolumn{6}{|c|}{ Test for overall effect: $Z=0.39(P=0.7)$} \\
\hline \multicolumn{6}{|c|}{ Test for subgroup differences: $\mathrm{Chi}^{2}=0.01, \mathrm{df}=1(\mathrm{P}=0.94), \mathrm{I}^{2}=0 \%$} \\
\hline
\end{tabular}

\section{APPENDICES}

\section{Appendix 1. CENTRAL search strategy}

1. MeSH descriptor: [Cerebrovascular Disorders] this term only

2. MeSH descriptor: [Basal Ganglia Cerebrovascular Disease] this term only

3. MeSH descriptor: [Brain Ischemia] explode all trees

4. MeSH descriptor: [Carotid Artery Diseases] explode all trees

5. MeSH descriptor: [Cerebral Small Vessel Diseases] explode all trees

6. MeSH descriptor: [Intracranial Arterial Diseases] explode all trees

7. MeSH descriptor: [Intracranial Embolism and Thrombosis] explode all trees

8. MeSH descriptor: [Intracranial Hemorrhages] explode all trees

9. $\mathrm{MeSH}$ descriptor: [Stroke] explode all trees

10. MeSH descriptor: [Stroke, Lacunar] this term only

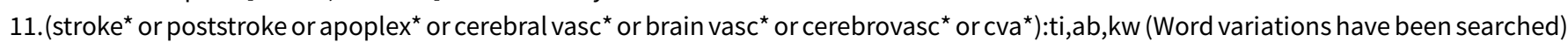

12.((brain or cerebr ${ }^{\star}$ or cerebell ${ }^{*}$ or vertebrobasil ${ }^{\star}$ or hemispher ${ }^{\star}$ or intracran $^{\star}$ or intracerebral or infratentorial or supratentorial or middle cerebral artery or $\mathrm{MCA}^{\star}$ or anterior circulation or posterior circulation or basilar artery or vertebral artery) near $/ 5$ (isch?emi* or infarct ${ }^{\star}$ or thrombo* or emboli* or occlus $\left.{ }^{\star}\right)$ :ti,ab, kw (Word variations have been searched)

13.((brain ${ }^{\star}$ or cerebr $^{*}$ or cerebell ${ }^{\star}$ or intracerebral or intracran ${ }^{\star}$ or parenchymal or intraparenchymal or intraventricular or infratentorial or supratentorial or basal gangli* or putaminal or putamen or posterior fossa or hemispher*) near/5 (h?emorrhag* or h?ematoma* or bleed $\left.\left.^{*}\right)\right): t i, a b, k w($ Word variations have been searched)

14. $\{$ or \#1-\#13\}

15.MeSH descriptor: [Deglutition] this term only

16.MeSH descriptor: [Deglutition Disorders] explode all trees

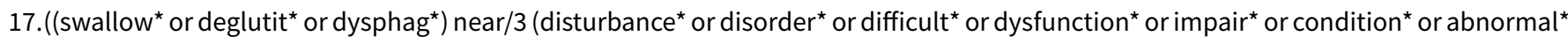
or damage ${ }^{*}$ or injur*)):ti,ab,kw (Word variations have been searched)

18.MeSH descriptor: [Pharynx] this term only

19. MeSH descriptor: [Pharyngeal Muscles] this term only

20.((pharyn* or oropharyn*) near/3 (disturbance* or disorder* or difficult* or dysfunction* or impair ${ }^{\star}$ or condition* or abnormal $^{\star}$ or damage $^{\star}$ or injur $\left.\left.{ }^{\star}\right)\right): t i, a b, k w($ Word variations have been searched)

21. $\{$ or \#15-\#20\}

22. \#14 and \#21

\section{Appendix 2. MEDLINE search strategy}

1. cerebrovascular disorders/ or basal ganglia cerebrovascular disease/ or exp brain ischemia/ or exp carotid artery diseases/or exp cerebral small vessel diseases/ or exp intracranial arterial diseases/ or exp "intracranial embolism and thrombosis"/ or exp intracranial hemorrhages/ or stroke/ or stroke, lacunar/

2. (stroke $\$$ or poststroke or apoplex $\$$ or cerebral vasc $\$$ or brain vasc $\$$ or cerebrovasc $\$$ or cva $\$$ ).tw.

3. ((brain\$ or cerebr\$ or cerebell\$ or vertebrobasil\$ or hemispher\$ or intracran\$ or intracerebral or infratentorial or supratentorial or middle cerebral artery or MCA\$ or anterior circulation or posterior circulation or basilar artery or vertebral artery) adj5 (isch?emi\$ or infarct\$ or thrombo or emboli\$ or occlus\$)).tw.

4. ((brain\$ or cerebr\$ or cerebell\$ or intracerebral or intracran\$ or parenchymal or intraparenchymal or intraventricular or infratentorial or supratentorial or basal gangli\$ or putaminal or putamen or posterior fossa or hemispher\$) adj5 (h?emorrhag\$ or h?ematoma or bleed\$)).tw. 
5. or/1-4

6. Deglutition/

7. exp Deglutition Disorders/

8. ((swallow\$ or deglutit\$ or dysphag\$) adj5 (disturbance\$ or disorder\$ or difficult\$ or dysfunction\$ or impair\$ or condition\$ or abnormal \$or damage $\$$ or injur\$)).tw.

9. Pharynx/ or pharyngeal muscles/

10. ((pharyn\$ or oropharyn\$) adj3 (disturbance $\$$ or disorder\$ or difficult $\$$ or dysfunction $\$$ or impair $\$$ or condition\$ or abnormal\$ or damage \$or injur\$)).tw.

11.or/6-10

12.randomized controlled trial.pt.

13. controlled clinical trial.pt.

14.randomized.ab.

15. placebo.ab.

16.random\$.ab.

17.trial.ab.

18.groups.ab.

19.or/12-18

20.5 and 11 and 19

Previous version of search strategy

1. stroke.mp.

2. infarction.mp.

3. exp cerebral infarction/

4. exp cerebrovascular disease/

5. cerebrovascular disease.mp.

6. hemorrhage.mp.

7. exp cerebral hemorrhage/

8. cerebral haemorrhage.mp.

9. 1 or 2 or 3 or 4 or 5 or 6 or 7 or 8

10.(dysphagia or deglutition or swallowing or deglutition disorders or swallowing disorders or malnutrition or undernutrition).mp.

11.(intervention or supplementation or feeding or nutrition or nutritional supplementation or therapy or swallowing therapy or tube feeding or fluid or fluid supplementation or sip feeding or feeding route or timing or diet or hydration).mp.

12.10 or 11

13.9 and 12

14.(randomized controlled trial.pt. or controlled clinical trial.pt.or randomized.ab. or placebo.ab. or clinical trials as topic.sh. or randomly.ab. or trial.ti.) and humans.sh.

15.13 and 14

\section{Appendix 3. Embase search strategy}

1. cerebrovascular disease/ or brain disease/ or exp basal ganglion hemorrhage/ or exp brain hematoma/ or exp brain hemorrhage/ or exp brain infarction/ or exp brain ischemia/ or exp carotid artery disease/ or exp cerebral artery disease/ or exp cerebrovascular accident/ or exp intracranial aneurysm/ or exp occlusive cerebrovascular disease/ or exp vertebrobasilar insufficiency/

2. (stroke or poststroke or apoplex\$ or cerebral vasc\$ or brain vasc\$ or cerebrovasc\$ or cva\$).tw.

3. ((brain or cerebr $\$$ or cerebell $\$$ or vertebrobasil\$ or hemispher $\$$ or intracran $\$$ or intracerebral or infratentorial or supratentorial or middle cerebral artery or MCA or anterior circulation or posterior circulation or basilar artery or vertebral artery) adj5 (isch?emi\$ or infarct\$ or thrombo $\$$ or emboli\$ or occlus\$)).tw.

4. ((brain\$ or cerebr\$ or cerebell\$ or intracerebral or intracran\$ or parenchymal or intraparenchymal or intraventricular or infratentorial or supratentorial or basal gangli\$ or putaminal or putamen or posterior fossa or hemispher\$) adj5 (h?emorrhag\$ or h?ematoma\$ or bleed\$)).tw.

5. or/1-4

6. dysphagia/

7. swallowing/

8. ((swallow\$ or deglutit\$ or dysphag\$) adj3 (disturbance\$ or disorder\$ or difficult\$ or dysfunction\$ or impair\$ or condition\$ or abnormal \$ or damage or injur\$)).tw. 
9. exp pharynx/

10. ((pharyn\$ or oropharyn\$) adj3 (disturbance $\$$ or disorder\$ or difficult $\$$ or dysfunction $\$$ or impair $\$$ or condition $\$$ or abnormal\$ or damage \$or injur\$)).tw.

11.or/6-10

12.Randomized Controlled Trial/ or "randomized controlled trial (topic)"/

13. Randomization/

14.Controlled clinical trial/ or "controlled clinical trial (topic)"/

15.control group/ or controlled study/

16.clinical trial/ or "clinical trial (topic)"/ or phase 1 clinical trial/ or phase 2 clinical trial/ or phase 3 clinical trial/ or phase 4 clinical trial/

17. Crossover Procedure/

18.Double Blind Procedure/

19.Single Blind Procedure/ or triple blind procedure/

20.placebo/ or placebo effect/

21.(random $\$$ or RCT or RCTs).tw.

22.(controlled adj5 (trial\$ or stud\$)).tw.

23. (clinical\$ adj5 trial\$).tw.

24. ((control or treatment or experiment $\$$ or intervention) adj5 (group\$ or subject\$ or patient $\$)) . t w$.

25. ((control or experiment\$ or conservative) adj5 (treatment or therapy or procedure or manage\$)).tw.

26. ((singl\$ or doubl\$ or tripl\$ or trebl\$) adj5 (blind\$ or mask\$)).tw.

27. (cross-over or cross over or crossover).tw.

28. (placebo\$ or sham).tw.

29.trial.ti.

30. (assign\$ or allocat\$).tw.

31.controls.tw.

32.or/12-31

33.5 and 11 and 32

Previous version of search strategy

1. stroke.mp.

2. infarction.mp.

3. exp brain Infarction/

4. cerebrovascular disease.mp.

5. exp cerebrovascular disease/

6. hemorrhage.mp.

7. exp cerebral hemorrhage/

8. cerebral haemorrhage.mp.

9. 9.1 or 2 or 3 or 4 or 5 or 6 or 7 or 8

10.(dysphagia or deglutition or swallowing or deglutition disorders or swallowing disorders or malnutrition or undernutrition).mp.

11.(intervention or supplementation or feeding or nutrition or nutritional supplementation or therapy or swallowing therapy or tube feeding or fluid or fluid supplementation or sip feeding or feeding route or timing or diet or hydration).mp.

12.10 or 11

13.09 and 12

14.((RANDOMIZED-CONTROLLED-TRIAL/ or RANDOMIZATION/ or CONTROLLED-STUDY/ or MULTICENTER-STUDY/ or PHASE-3-CLINICALTRIAL/ or PHASE-4-CLINICAL-TRIAL/ or DOUBLE-BLIND-PROCEDURE/ or SINGLE-BLIND-PROCEDURE/) or ((RANDOM* or CROSS?OVER*

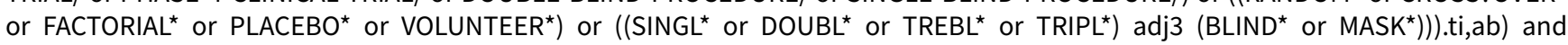
human*.ec,hw,fs.

15.13 and 14

\section{Appendix 4. CINAHL search strategy}

1. S1 (MH "Cerebrovascular Disorders") OR (MH "Basal Ganglia Cerebrovascular Disease+") OR (MH "Carotid Artery Diseases+") OR (MH "Cerebral Ischemia+") OR (MH "Cerebral Vasospasm") OR (MH "Intracranial Arterial Diseases+") OR ( (MH "Intracranial Embolism and Thrombosis") ) OR (MH "Intracranial Hemorrhage+") OR (MH "Stroke") OR (MH "Vertebral Artery Dissections") OR (MH "Stroke Patients") OR (MH "Stroke Units") 
2. S2 TI ( stroke or poststroke or post-stroke or cerebrovasc* or brain vasc* or cerebral vasc or cva or apoplex ) or AB ( stroke or poststroke or post-stroke or cerebrovasc ${ }^{\star}$ or brain vasc ${ }^{\star}$ or cerebral vasc or cva or apoplex)

3. S3 TI ((brain or cerebr ${ }^{\star}$ or cerebell* or vertebrobasil* or hemispher* or intracran ${ }^{\star}$ or intracerebral or infratentorial or supratentorial or middle cerebral artery or $\mathrm{MCA}^{\star}$ or anterior circulation or posterior circulation or basilar artery or vertebral artery ) N5 (ischemi* or ischaemi ${ }^{\star}$ or infarct* or thrombo* or emboli* or occlus $\left.{ }^{\star}\right)$ ) OR AB ((brain or cerebr ${ }^{\star}$ or cerebell ${ }^{\star}$ or vertebrobasil ${ }^{\star}$ or hemispher $^{\star}$ or intracran* or intracerebral or infratentorial or supratentorial or middle cerebral artery or $\mathrm{MCA}^{\star}$ or anterior circulation or posterior circulation or basilar artery or vertebral artery ) N5 ( ischemi* or ischaemi* or infarct* or thrombo* or emboli* or occlus $\left.{ }^{\star}\right)$ )

4. S4 TI (( brain* or cerebr ${ }^{\star}$ or cerebell ${ }^{\star}$ or intracerebral or intracran ${ }^{\star}$ or parenchymal or intraparenchymal or intraventricular or infratentorial or supratentorial or basal gangli* or putaminal or putamen or posterior fossa or hemispher ${ }^{\star}$ ) N5 ( haemorrhage* or hemorrhage* or haematoma* or hematoma* or bleed*)) OR AB (( brain* or cerebr* or cerebell* or intracerebral or intracran* or parenchymal or intraparenchymal or intraventricular or infratentorial or supratentorial or basal gangli* or putaminal or putamen or posterior fossa or hemispher ${ }^{\star}$ ) N5 ( haemorrhage* or hemorrhage* or haematoma* or hematoma* or bleed ${ }^{\star}$ ))

5. S5 S1 OR S2 OR S3 OR S4

6. S6 (MH "Deglutition") OR (MH "Gagging")

7. $\mathrm{S} 7$ (MH "Deglutition Disorders")

8. S8 TI ( (swallow ${ }^{\star}$ or deglutit ${ }^{\star}$ or dysphag ${ }^{\star}$ ) N3 (disturbance ${ }^{\star}$ or disorder ${ }^{\star}$ or difficult ${ }^{\star}$ or dysfunction ${ }^{\star}$ or impair ${ }^{\star}$ or condition ${ }^{\star}$ or abnormal* or damage ${ }^{\star}$ or injur ${ }^{\star}$ ) ) OR AB ( (swallow* or deglutit* or dysphag*) N3 (disturbance* or disorder ${ }^{\star}$ or difficult* or dysfunction* or impair ${ }^{\star}$ or condition* or abnormal ${ }^{\star}$ or damage $^{\star}$ or injur $\left.^{\star}\right)$ )

9. S9 TI ((swallow* ${ }^{\star}$ or deglutit* or dysphag $\left.{ }^{\star}\right)$ N3 $\left(\right.$ scale $^{\star}$ or screen ${ }^{\star}$ or checklist* or assess ${ }^{\star}$ or exam ${ }^{\star}$ or identif* or recogni or evaluat $^{\star}$ or diagnos $^{\star}$ or detect* or hazard or risk or test)) OR AB ((swallow* or deglutit* or dysphag*) N3 (scale* or screen* or checklist* or assess ${ }^{\star}$ or exam ${ }^{\star}$ or identif* or recogni* or evaluat* or diagnos $^{\star}$ or detect $^{\star}$ or hazard or risk or test))

10.S10 S6 OR S7 OR S8 OR S9

11.S11 MH Random Assignment or MH Single-blind Studies or MH Double-blind Studies or MH Triple-blind Studies or MH Crossover design or MH Factorial Design

12.S12 TI ("multicentre study" or "multicenter study" or "multi-centre study" or "multi-center study") or AB ("multicentre study" or "multicenter study" or "multi-centre study" or "multi-center study") or SU ("multicentre study" or "multicenter study" or "multi-centre study" or "multi-center study")

13.S13 TI random* or AB random*

14.S14 AB "latin square" or TI "latin square"

15.S15 TI (crossover or cross-over) or AB (crossover or cross-over) or SU (crossover or cross-over)

16.S16 MH Placebos

17.S17 TI ( ((singl ${ }^{\star}$ or doubl ${ }^{\star}$ or trebl* or tripl $\left.l^{\star}\right)$ N3 $\left(\right.$ blind $^{\star}$ or mask $\left.\left.^{\star}\right)\right)$ ) OR AB ( ((singl ${ }^{\star}$ or doubl or trebl $^{\star}$ or tripl $\left.l^{\star}\right)$ N3 $\left(\right.$ blind $^{\star}$ or mask $\left.\left.^{\star}\right)\right)$ )

18.S18 TI Placebo* or AB Placebo* or SU Placebo*

19.S19 MH Clinical Trials

20.S20 TI (Clinical AND Trial) or AB (Clinical AND Trial) or SU (Clinical AND Trial)

21.S21 S11 OR S12 OR S13 OR S14 OR S15 OR S16 OR S17 OR S18 OR S19 OR S20

22.S22 S5 AND S10 AND S21

Previous version of review search strategy

1. S1. stroke

2. S2. infarction

3. S3. brain Infarction

4. S4. cerebrovascular disease

5. S5. hemorrhage

6. S6. cerebral hemorrhage

7. S7. cerebral haemorrhage

8. $\mathrm{S} 8 . \mathrm{S} 1$ or $\mathrm{S} 2$ or $\mathrm{S} 3$ or $\mathrm{S} 4$ or $\mathrm{S} 5$ or $\mathrm{S} 6$ or $\mathrm{S} 7$

9. S9. dysphagia or deglutition or swallowing or deglutition disorders or swallowing disorders or malnutrition or undernutrition

10.S10. intervention or supplementation or feeding or nutrition or nutritional supplementation or therapy or swallowing therapy or tube feeding or fluid or fluid supplementation or sip feeding or feeding route or timing or diet or hydration

11.S11. S9 or S10

12.S12. S8 and S11

13.S13. randomised controlled trials or controlled clinical trial or randomized or clinical trials

14.S14. S12 and S13 


\section{Appendix 5. Web of Science search strategy}

1. $\mathrm{TS}=\left(\right.$ stroke$^{\star}$ or poststroke or apoplex ${ }^{\star}$ or cerebral vasc ${ }^{\star}$ or brain vasc ${ }^{\star}$ or cerebrovasc or cva $\left.^{\star}\right)$

2. TS=((brain or cerebr ${ }^{\star}$ or cerebell ${ }^{*}$ or vertebrobasil ${ }^{\star}$ or hemispher ${ }^{\star}$ or intracran* or intracerebral or infratentorial or supratentorial or middle cerebral artery or $\mathrm{MCA}^{\star}$ or anterior circulation or posterior circulation or basilar artery or vertebral artery) NEAR/5 (isch?emi ${ }^{\star}$ or infarct* or thrombo $^{\star}$ or emboli* or occlus $\left.{ }^{\star}\right)$ )

3. TS=((brain* or cerebr ${ }^{\star}$ or cerebell* or intracerebral or intracran ${ }^{\star}$ or parenchymal or intraparenchymal or intraventricular or infratentorial or supratentorial or basal gangli ${ }^{\star}$ or putaminal or putamen or posterior fossa or hemispher ${ }^{\star}$ ) NEAR/5 (h?emorrhag* or h?ematoma* or bleed $\left.{ }^{*}\right)$ )

4. \#3 OR \#2 OR \#1

5. TS=((swallow* or deglutit* or dysphag*) NEAR/3 (disturbance* or disorder* or difficult* or dysfunction ${ }^{\star}$ or impair $^{\star}$ or condition* $^{\star}$ or abnormal ${ }^{*}$ or damage* or injur $\left.\left.^{\star}\right)\right)$

6. TS=((pharyn* or oropharyn $\left.{ }^{\star}\right)$ NEAR/3 (disturbance* or disorder ${ }^{\star}$ or difficult* or dysfunction ${ }^{\star}$ or impair ${ }^{\star}$ or condition ${ }^{\star}$ or abnormal ${ }^{\star}$ or damage* or injur*))

7. \#6 OR \#5

8. $\mathrm{TS}=\left(\right.$ random ${ }^{\star}$ or RCT or RCTs)

9. $\mathrm{TS}=\left(\right.$ controlled NEAR/5 $\left(\right.$ trial $^{*}$ or $\left.\left.\operatorname{stud}^{\star}\right)\right)$

10. $\mathrm{TS}=\left(\right.$ clinical $^{\star} \mathrm{NEAR} / 5$ trial $\left.^{\star}\right)$

11. TS $=\left(\left(\right.\right.$ control or treatment or experiment ${ }^{\star}$ or intervention) NEAR/5 (group or subject $^{\star}$ or patient $\left.\left.{ }^{\star}\right)\right)$

12. $\mathrm{TS}=\left(\left(\right.\right.$ control or experiment ${ }^{\star}$ or conservative) NEAR/5 (treatment or therapy or procedure or m.anage $)$ )

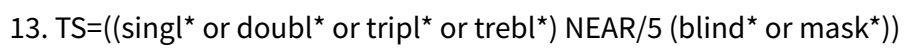

14. TS=(cross-over or cross over or crossover)

15. $\mathrm{TS}=\left(\right.$ placebo ${ }^{\star}$ or sham $)$

16. $\mathrm{TS}=$ trial

17. \#16 OR \#15 OR \#14 OR \#13 OR \#12 OR \#11 OR \#10 OR \#9 OR \#8

18. \#17 AND \#7 AND \#4

Previous version of review search strategy

1. stroke

2. infarction

3. brain infarction

4. cerebrovascular disease

5. hemorrhage

6. cerebral haemorrhage

7. cerebral hemorrhage

8. 1 or 2 or 3 or 4 or 5 or 6 or 7

9. dysphagia or deglutition or swallowing or deglutition disorders or swallowing disorders

10.randomized controlled trial or controlled clinical trial randomized or placebo or clinical trials or trial

11.8 and 9 and 10

\section{Appendix 6. SpeechBITE search stategy}

1. Speech Pathology Practice Area: Dysphagia

2. Type of intervention: Swallowing/ feeding

3. Within this population: Stroke/CVA

4. Research Design : Randomised Controlled Trial

5. Age group: Adults

1. Speech Pathology Practice Area: Dysphagia

2. Type of intervention: Swallowing/ feeding

3. Within this population: Stroke/CVA

4. Research Design: Non Randomised Controlled Trial

5. Age group: Adults 


\section{Appendix 7. US National Institutes of Health Ongoing Trials Register ClinicalTrials.gov (www.clinicaltrials.gov)}

1. (Dysphagia AND (Brain Infarction OR Intracranial Hemorrhages OR Carotid Artery Diseases OR Brain Ischemia OR Cerebral Hemorrhage OR Cerebrovascular Disorders OR Stroke ) ) [DISEASE]

\section{Appendix 8. World Health Organization International Clinical Trials Registry Platform (apps.who.int/trialsearch)}

1. stroke AND swallowing OR stroke AND dysphagia

\section{Appendix 9. Google Scholar}

1. Stroke

2. Dysphagia

3. Interventions

4. Randomised Controlled Trials

\section{WHAT'S NEW}

\begin{tabular}{lll}
\hline Date & Event & Description \\
\hline 28 March 2018 & $\begin{array}{l}\text { New citation required but conclusions } \\
\text { have not changed }\end{array}$ & $\begin{array}{l}\text { More significant outcomes reported as compared to the 2012 re- } \\
\text { view, but largely based on moderate- to low-quality evidence. } \\
\text { Changes made to authorship }\end{array}$ \\
\hline 28 March 2018 New search has been performed & $\begin{array}{l}\text { New studies added. 14 studies (883 participants) included in the } \\
2012 \text { review. 27 studies (1777 participants) added to this updat- } \\
\text { ed review. Total number of included studies reported is 41 (2660 } \\
\text { participants). Focus of this review is limited to treatment of dys- } \\
\text { phagia in acute and subacute stroke (nutritional, feeding, and } \\
\text { fluid support removed from this review and will become the fo- } \\
\text { cus of a separate review) }\end{array}$ \\
\hline
\end{tabular}

\section{H I S T O R Y}

Protocol first published: Issue 1, 1997

Review first published: Issue 4, 1999

\begin{tabular}{lll}
\hline Date & Event & Description \\
\hline 14 March 2012 & $\begin{array}{l}\text { New citation required but conclusions } \\
\text { have not changed }\end{array}$ & Changes made to authorship. No changes made to conclusions \\
\hline 14 March 2012 & New search has been performed & $\begin{array}{l}\text { Results of 27 new studies involving 6567 participants added to } \\
\text { the review. Total of 33 studies involving 6779 participants now } \\
\text { included. 15 new ongoing studies also added. Modifications } \\
\text { made to analysis method, types of stroke patients included, and } \\
\text { outcome measures assessed (Differences between protocol and } \\
\text { review) }\end{array}$ \\
\hline 13 April 2008 & Amended & Review converted to new review format \\
\hline
\end{tabular}

\section{CONTRIBUTIONS OF AUTHORS}

Philip Bath: conceived and designed the review, undertook searches, analysed and interpreted data, wrote the original review, and updated the review in 2007 (interim update), 2012, and 2018. 
Han Sean Lee: undertook searches, extracted data, analysed and interpreted data, and updated the review in 2018.

Lisa Everton: undertook searches and data extraction, analysed and interpreted data, and updated the review in 2018.

\section{DECLARATIONS OF INTEREST}

PB was chief investigator of two included trials (Bath 1997, academic; STEPS 2016, commercial - funded by Phagenesis Ltd); he consults for this company and receives honoraria and expenses for this work; he did not contribute to decisions on PES studies including deciding which trials should be included and extracting outcome data. No pharmaceutical or device companies, or other commercial entities, were involved in data analysis, data interpretation, writing of this review, or comments on it.

SL: none known.

LE: none known.

\section{SOURCES OF SUPPORT}

\section{Internal sources}

- King's College Hospital Audit Committee, UK.

- Division of Stroke, University of Nottingham, UK.

\section{External sources}

- South Thames NHS Executive, UK.

- Trent NHS Executive, UK.

- Wolfson Foundation, UK.

- The Stroke Association, UK.

- Royal College of Physicians, UK.

- Dunhill Medical Trust, UK.

- National Institutes of Health Research Stroke Research Network, UK.

Support for recruitment of patients into UK-based trials

- National Institutes of Health Research - Cochrane Incentive Scheme, UK.

\section{DIFFERENCES BETWEEN PROTOCOL AND REVIEW}

\section{Separation of dysphagia treatment from nutritional support}

For this version of the review, we removed all trials related to nutritional support and feeding to allow focus on swallowing therapy for post-stroke dysphagia.

\section{Modification of analysis method}

We changed the analysis method from fixed-effect to random-effects models (odds ratio (OR), mean difference (MD)) because we noted the presence of significant trial and statistical heterogeneity. Two studies included more than one interventional group (Yuan 2003; Carnaby 2006), producing different treatment intensities. In these cases, we divided the low-intensity (middle) groups and entered data from the study as two data sets (e.g. data set 1: medium (M), low (L), or none; and data set 2: high (H) or medium (M)). Similarly, in the case of repetitive transcranial magnetic stimulation, when a trial compared high- versus low-frequency stimulation or unilateral versus bilateral stimulation (Kim 2012i; Kim 2012ii; Du 2016i; Du 2016ii; Park 2016a (i); Park 2016a (ii)), we divided control group participants equally between treatment groups to prevent counting control participants more than once, thereby artificially narrowing the confidence intervals (Cls).

We combined different interventions, collectively referred to as 'swallowing therapy', for the purposes of analysing their effects on main outcomes to evaluate whether any intervention is better than no intervention, and to try to establish where the most positive effects are seen, and where more research is needed.

\section{Modification of type of stroke patients}

We excluded trials in which a majority of participants did not present with stroke, along with trials for which enrolment occurred after six months. 


\section{Addition or modification of outcome measures}

Modification of search strategies: we have revised and updated the search strategies used for this review to account for newly identified relevant terms keywords and indexing terms. We have included both versions of each search strategy in the review appendices.

We divided swallowing therapy into subcategories: acupuncture, drug therapy, NMES, PES, physical stimulation (thermal, tactile), tDCS, and TMS.

We added additional outcome measures, especially focusing on intermediate outcomes: chest infection or pneumonia rates and penetration aspiration scores. We retained outcomes related to improvement of dysphagia as listed with proportion of participants with dysphagia at end of trial. However, we also included changes in some measurements on videofluoroscopy (pharyngeal transit time) and changes in swallowing ability as determined by change in swallow scores. We included discharge destination within the outcome 'institutionalisation': the number of participants discharged to long-term care.

\section{INDEX TERMS}

\section{Medical Subject Headings (MeSH)}

*Stroke Rehabilitation; Acupuncture Therapy [statistics \& numerical data]; Acute Disease; Deglutition; Deglutition Disorders [ ${ }^{\star}$ etiology] [mortality] [ ${ }^{\star}$ rehabilitation]; Electric Stimulation Therapy [statistics \& numerical data]; Gastrostomy; Intubation, Gastrointestinal; Length of Stay [statistics \& numerical data]; Lisinopril [therapeutic use]; Metoclopramide [therapeutic use]; Nifedipine [therapeutic use]; Physical Stimulation [methods]; Pneumonia [epidemiology]; Randomized Controlled Trials as Topic; Stroke [ ${ }^{*}$ complications] [mortality]; Time Factors; Transcranial Direct Current Stimulation [statistics \& numerical data]

\section{MeSH check words}

Humans 